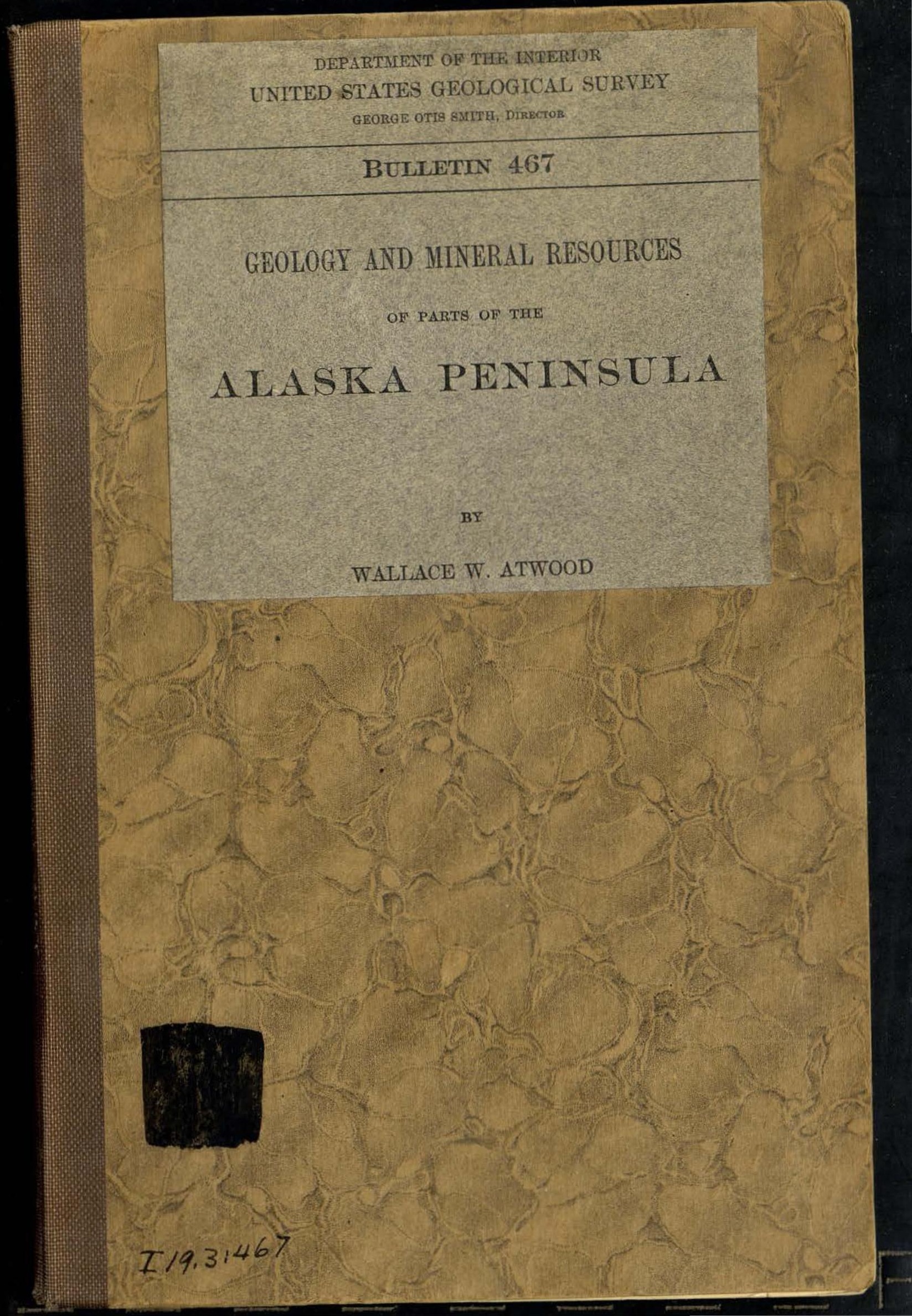





\section{$A D D-9883$}

DEPARTMENT OF THE INTERIOR

UNITED STATES GEOLOGICAL SURVEY

GEORGE OTIS SMITH, DIRECTOR

BULLETIN 467

GEOLOGY AND MINERAL RESOURCES

OF PARTS OF THE

\section{ALASKA PENINSULA}

BY

WALLACE W. ATWOOD

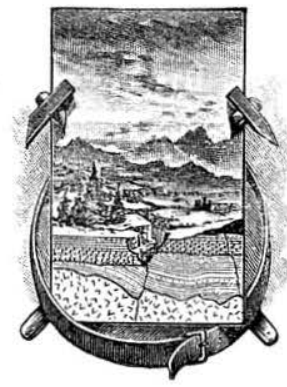

WASHINGTON

GOVERNMENT PRINTING OFFICE

1911

LIBITAKY

TEXAS TECHNOLOGICAL COLLEGE,

LUBBOCH' IE:AS 



\section{CONTENTS.}

Preface, by Alfed $\mathrm{H}$ Page.

Preface, by Alred H. Brooks ...........................................

Location and extent of area considered.............................. 9

Previous explorations and surveys.................................. 9

Acknowledgments............................................ 12

Character of the country ................................................ 13

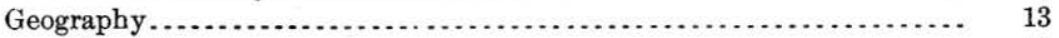

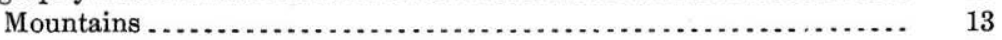

Lowlands ........................................................ 14

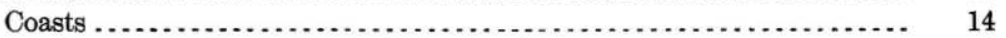

Drainage............................................... 15

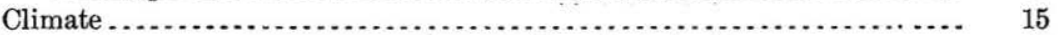

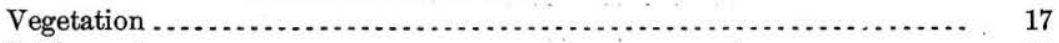

Settlement ....................................................... 18

Commercial development ..................................... 19

Transportation ................................................... 22

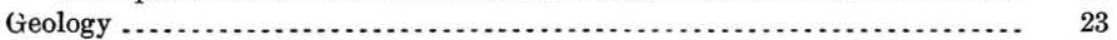

General features............................................... 23

Age and succession of the rocks ............................. 23

Distribution of formations. ................................ 26

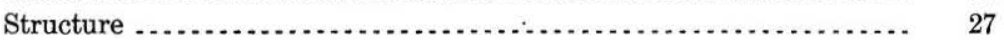

Stratigraphy ................................................ 29

Character and distribution of the rocks.......................... $\quad 30$

Argillite of unknown age ................................. 30

Triassic system............................................. 30

Jurassic system............................................ 31

Jower Jurassic rocks.................................. 31

Granites and syenites, probably of Lower or Middle Jurassic age. $\quad 31$

Middle Jurassic rocks ("Enochkin formation") ............... 32

Upper Jurassic rocks..................................... 33

Naknek formation.................................... 33

Cretaceous system ....................................... 38

Lower Cretaceous rocks.............................. 38

Staniukovich shale................................. 38

Herendeen limestone............................ $\quad 39$

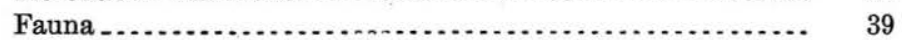

Stratigraphic relations.............................. 40

Upper Cretaceous rocks................................. 41

Chignik formation................................. 41

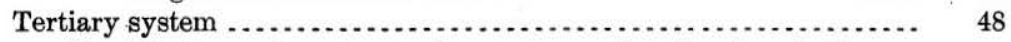

Basaltic flows, breccias, agglomerates, and tuffs of early Eocene age ................................................ 48

Eocene series .............................................. 49

Kenai formation.................................... 49

Oligocene series (?) ..................................... 59

Late Eocene or early Miocene andesites, tuffs, breccias, and glass. $\quad 59$ 
Geology-Continued

Character and distribution of the rocks-Continued.

Page.

Tertiary system-Continued.

Late Eocene or later igneous rocks........................ 63

Augite porphyry flow breccia.......................... 63

Dacites ................................................... 63

Diorite-porphyrite................................ 65

Miocene series .... ...................................... 66

Unga formation ........................................... 66

Post-Miocene basaltic flows and tuffs...................... 69

Pliocene series (?) ..................................... 71

Summary of the igneous rocks......................... 71

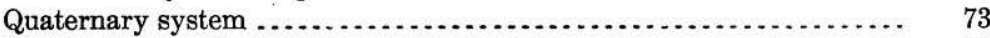

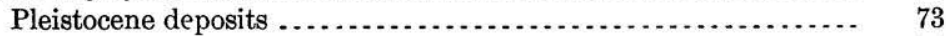

Recent deposits . . . . . . . . . . . . . . . .

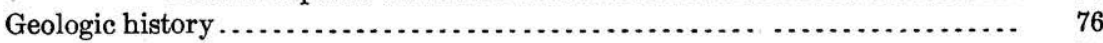

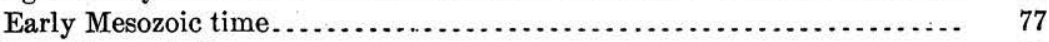

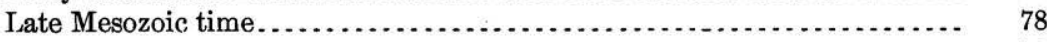

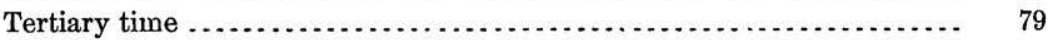

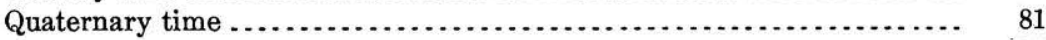

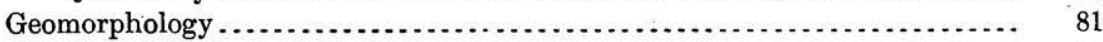

Means of interpretation . ......

Eocene sedimentation and the growth of the Aleutian Range . . . . . . . . $\quad 82$

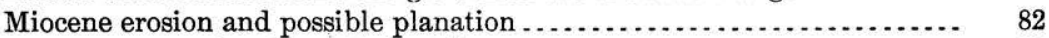

Deformation at the close of the Miocene....................... 83

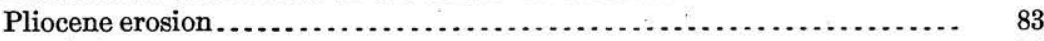

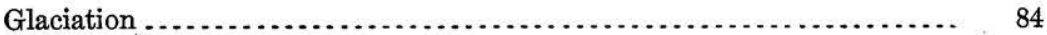

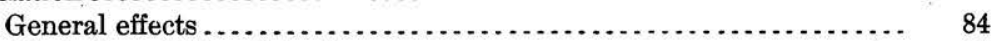

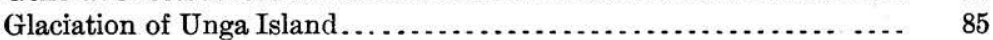

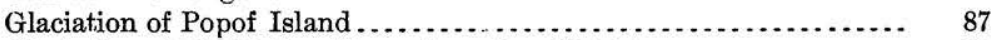

Glaciation of the Balboa-Herendeen Bay district ............... 87

Glaciation of the Chignik Bay region .................... 90

Retreat of the ice....................................... 91

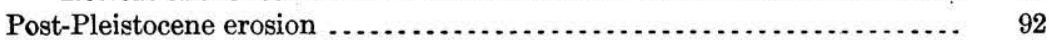

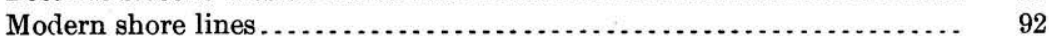

Recent changes in level........................................ 94

Summary of late geologic history ....................... 95

Mineral resources .......................................... 95

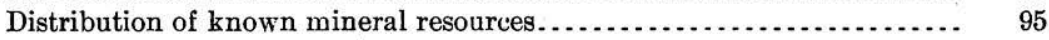

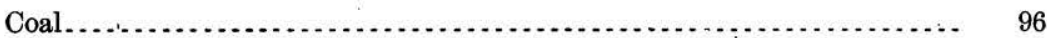

Herendeen Bay coal field

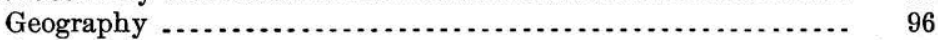

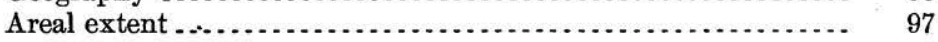

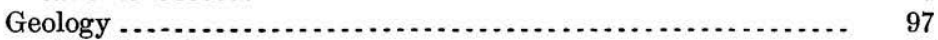

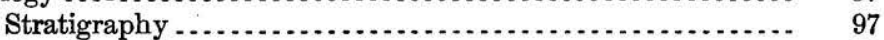

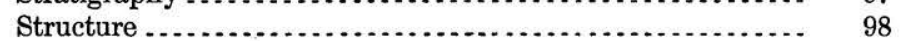

The coal measures................................... 100

Character of the coal...................................... 103

Physical properties.................................... 103

Combustion.............................................. 104

Chemical and calorimetric properties ................. 104

Prospective mining conditions. ............................ 106

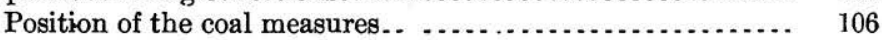

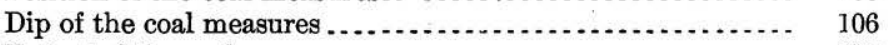

Extent of the coal measures . ........................ 107

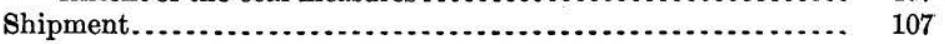


Mineral resources-Continued. Page.

Coal-Continued.

Chignik Bay coal field ..................................... 108

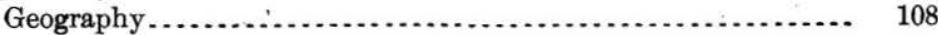

Areal extent . . . . . . . . .

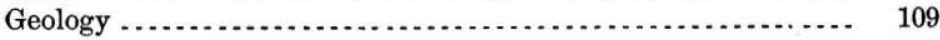

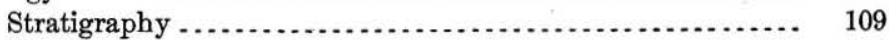

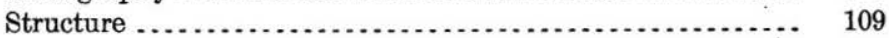

The coal measures.................................... 110

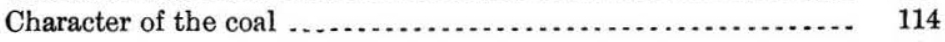

Physical properties............................... 114

Combustion....................................... 115

Chemical and calorimetric properties ................. 115

Prospective mining conditions. .......................... 115

Position of the coal measures. . ..................... 115

Dip and extent of the coal. ....................... 116

Shipment......................................... 116

Cold Harbor coal field . . . . . . . . . . . . . . . . 117

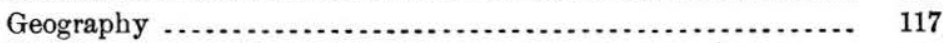

Development work .................................. 117

Areal extent . ............................................ 118

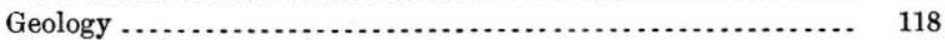

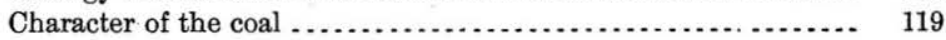

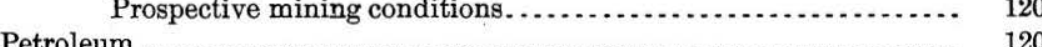

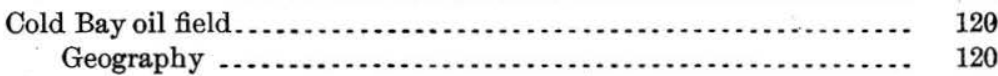

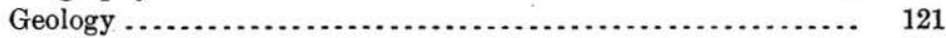

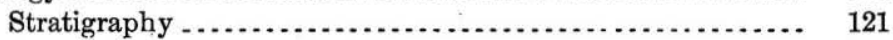

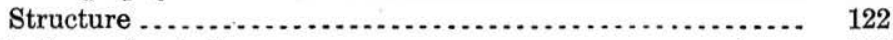

Indications of petroleum. . .

Seepages............................................. 122

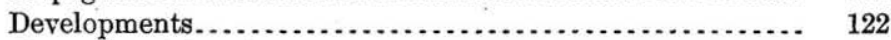

Character of the oil. ............................... 123

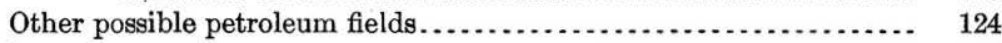

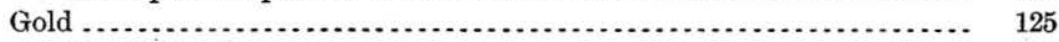

Popof Island . . . . . . . . . . . . . . .

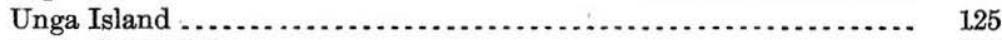

Unalaska Island . . . .

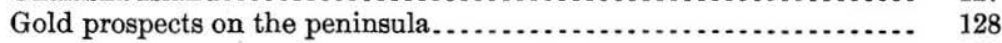

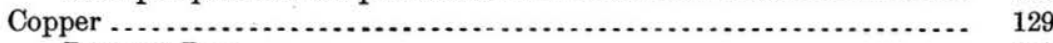

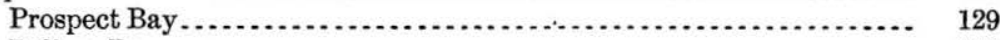

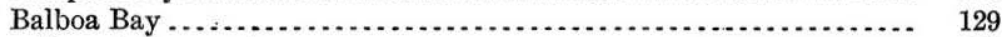

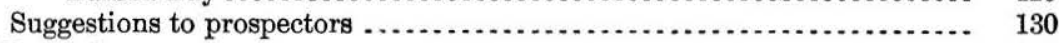

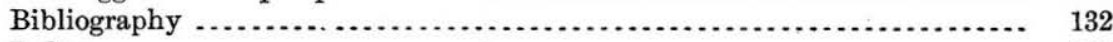

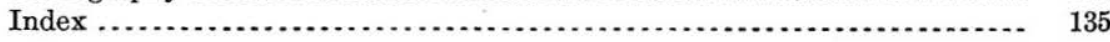

\section{ILLUSTRATIONS.}

Plate I. Outline map of southwestern Alaska, showing area under consideration and smaller areas included in certain maps in this report....

II. Topographic map of the Balboa-Herendeen Bay and Unga Island region. 
Plate III. A, Volcanic peaks on west shore of Pavlof Bay, Alaska Peninsula; $B$, Cathedral Peak, one of the higher summits in the Aleutian Range near Balboa Bay.

IV. $A$, Mountains and glaciers west of Cape Douglas; $B$, View of Cape

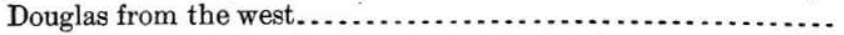

V. A, Tuliumit Point, locally known as Castle Cape, at south entrance to Chignik Bay; $B$, East coast of Unga Island north of Unga Harbor . .......................................

VI. Geologic reconnaissance map of the Alaska Peninsula........ In pocket.

VII. Reconnaissance geologic and topographic map of the Chignik Bay region of Alaska .......................................

VIII. Reconnaissance geologic map of the Balboa-Herendeen Bay and Unga Island region of Alaska.............................

IX. A, Pyramid Mountain, near axis of Aleutian Range northwest from Balboa Bay; $B$, Shore line stack or pillar on east shore of Unga Island

Page.

X. $A$, Elevated sea terrace at northeast end of Unga Island; $B$, Detailed view of coarse volcanic tuff of post-Miocene age, as exposed on

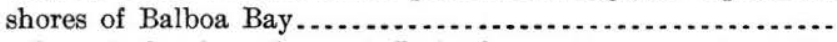

XI. $A$, Unga Harbor from the west; $B$, Anchorage Bay from the southwest

XII. A, Sea caves, and an arch rock along east coast of Unga Island;

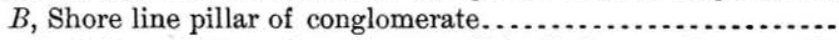

XIII. A, Hook Bay, near north entrance to Chignik Bay; $B$, Exposure in the upper coal seam in Thompson Valley .....................

XIV. $A$, Entrance to Chignik River coal mine; $B$, Tunnel opening in

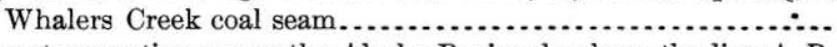

Figure 1. Structure section across the Alaska Peninsula along the line A-B, Plate VI. . . . . . . . . . . . . . . . .

2. Structure section across the Alaska Peninsula along the line C-D,

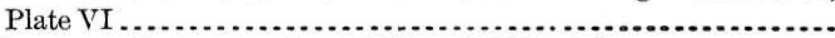

3. Diagrammatic cross section of Pinnacle Mountain ................

4. Geologic sketch map of Cape Douglas and vicinity ................

5. Structure section across the Alaska Peninsula near Balboa Bay along the line C-D, Plate VIII. . . . .

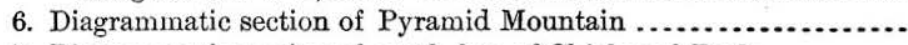

7. Diagrammatic section of south face of Chichagof Peak............

8. Structure section at the north end of Unga Island along the line

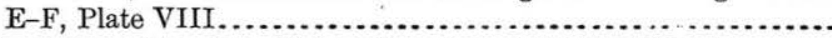

9. Structure section along the northeast coast of Unga Island .........

10. Diagrammatic section along east shore of Unga Island south of Baralof or Squaw Harbor .................................

11. Sketch map of shore features near south entrance to Baralof Har-

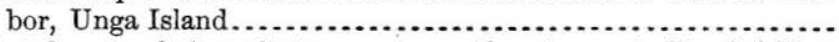

12. Sketch map of shore features near north entrance to Baralof Harbor, Unga Island. ....................................

13. Structure section across Herendeen Bay coal field along the line

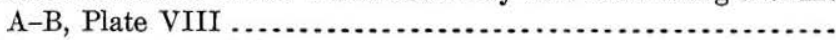

14. Columnar section of the coal measures at Herendeen Bay and Coal Harbor

15. Sections of coal seams in the Chignik Bay and Herendeen Bay fields ard at Coal Harbor ...................................

16. Sketch map of the shore features near the bead of Balboa Bay...

17. Vertical section at Coal Harbor mine, Unga Island...............

18. Sketch map of a portion of Prospect Bay ..................... 


\section{PREFACE.}

\section{By Alfred H. Brooks.}

During the Russian occupation of Alaska many facts concerning the geology of Alaska Peninsula were collected, but Dall and Becker's study of the coal and gold deposits of Unga Island and of some of the coal beds of the mainland in 1895 represents the first attempt at systematic investigation of the mineral resources. Martin, in 1903 and 1904, made the first examination of the petroleum seepages. Meanwhile other investigators had contributed to the knowledge of the general geology, the most notable work being Martin and Stanton's summary of the Mesozoic stratigraphy.

The pursuance of the general plan of investigating the coal resources of Alaska led to the surveys here reported. Mr. Atwood's chief purpose was to survey the three most important local coal fields, the Chignik, Herendeen Bay, and Unga, but incidentally he collected considerable information in regard to the general geology and mineral resources of the entire peninsula. The data thus gathered, together with the results of previous investigations, have been embodied in this report.

Mapping was done in some detail in the surveyed coal fields and the results are set forth with considerable confidence as to their accuracy. Far less definite.information was obtained as to the areal and stratigraphic geology and mineral deposits of the rest of the peninsula. Therefore the sections devoted to these subjects must be regarded simply as a summary of the best information available. It is believed, however, that this report will serve as a useful reference book both to those who are developing the mineral resources of the peninsula and to those who are interested in the more purely scientific problems. If funds are available, more detailed investigations of the geology and mineral deposits will be undertaken when the mining advancement seems to demand them.

The discovery of gold in California and the consequent increase in the population of that State led to a demand for fuel along the Pacific seaboard, and this demand provided the first incentive to the search for coal in Alaska. As early as 1854 attempts were made to mine coal on Cook Inlet. Coal claims were staked on Unga Island 
in the early seventies and 10 years later some systematic mining at this and other localities in southwestern Alaska was begun. The rapid development of the more accessible coal fields of California, Washington, and Vancouver Island, which began about 1870, supplied the west coast market, and from that time until very recently little attention has been given to Alaska coal. Mining to supply local demand has, however, continued in the peninsula to the present day.

The coal of Alaska Peninsula is not of as high grade as that of the Bering River and Matanuska fields, but the fields are more accessible. The fields here described are all near good harbors, a location that will give them an advantage over the higher-grade coals of other Alaska fields. Moreover, their close proximity to the great circle route from Puget Sound to Yokohama will certainly eventually accrue to their benefit, though it must be confessed that their immediate use for trans-Pacific shipment does not seem practicable. On the other hand, unless petroleum is found, they furnish the only local source of fuel for Alaska Peninsula, which is without timber.

Some drilling for oil has been done on the peninsula, but it has not shown either the presence or the absence of a commercially valuable pool. It appears, however, that the geologic data at hand warrant the continuation of the search.

So far as known geologic conditions like those on Unga Island, where successful gold mining has been carried on for many years, may be found in other parts of the Province, so that there seems to be a field here that warrants the attention of the lode prospector.

Except for the absence of timber, the conditions in Alaska Peninsula are more favorable for mining than in many other parts of the Territory. The open season is longer and the winter is less severe than in the interior or in Seward Peninsula. Numerous good harbors are open to navigation throughout the year. The luxuriant growth of grass in the peninsula, except in the high mountains, favors the use of horses, and the many streams and lakes render much of the region readily accessible to small boats. 


\title{
GEOLOGY AND MINERAL RESOURCES OF PARTS OF THE ALASKA PENINSULA.
}

\author{
By Wallace W. Atwood.
}

\section{INTRODUCTION.}

LOCATION AND EXTENT OF AREA CONSIDERED.

The regions under consideration in this report are included within that portion of Alaska that extends southwestward from Cook Inlet to Unimak Pass. This land area is a relatively narrow peninsula, tapering from a width of about 100 miles at the northeast end to about 20 miles at the southwest end. (See Pl. I.)

A line drawn from Cape Douglas to the head of Bristol Bay may be taken as the northeast limit of the peninsula. The western limit, strictly defined, is at the margin of the land just east of Unimak Island. The water route between Unimak Island and the true end of the peninsula is, however, narrow and very shallow, being unnavigable except by small boats, and since the physiographic break is so slight the peninsula has been here defined, for convenience in description, as extending to the western margin of Unimak Island or to Unimak Pass. This land is included between $54^{\circ}$ and $59^{\circ}$ north latitude and $153^{\circ}$ and $165^{\circ}$ west longitude. The linear extent of the peninsula from northeast to southwest is approximately 550 miles; the areal extent is fully 30,000 square miles. Numerous islands, some of which will be referred to in this report, are associated with the peninsula. The total land area of these islands, not including the Kodiak group, is probably about 4,000 square miles.

\section{PREVIOUS EXPLORATIONS AND SURVEYS.}

Early explorations.-Previous to 1741 southwestern Alaska had not been visited by white people. In that year Vitus Bering, a Dane commissioned in the Russian Navy, left the coast of Kamchatka in command of an expedition to search for a continent to the east. The expedition sailed in two vessels, one commanded by Bering himself and the other by his lieutenant, Chirikof. The vessels soon became separated, and Bering, after following a very irregular course, reached 
the American coast neär Mount St. Elias. On his return journey westward he discovered the Shumagin group of islands, among which he remained several days, and passed along the coast to the westward within sight of several of the Aleutian Islands. Chirikof sailed east and sighted the American coast, probably near Cross Sound. He, like Bering, sighted some of the Aleutian Islands on his return journey. During the following half century hardy Siberian fur hunters, called promyshleniki, ventured into these unknown seas in search of valuable furs, the existence of which had been reported by the members of Bering's crew. These daring men pushed their way eastward along the Aleutian chain of islands to the mainland of Alaska, and their ultimate mastery of the region led to Russia's becoming a North American power.

About 1767 Capt. Krenitzin, of the Russian Navy, was sent out to explore the American coast. He determined astronomically a few positions in the eastern part of the Aleutian chain of islands and along the southern coast of the Alaska Peninsula.

The first important systematic survey of any part of what is now known as Alaska was made by Capt. Cook, the great Englishnavigator. He made a landing in May, 1778, near Mount Edgecumbe, in southeastern Alaska, after which he sailed westward, exploring Prince William Sound and Cook Inlet, and thence southwestward along the southern shore of the Alaska Peninsula as far as Unalaska Island. Cook next entered Bering Sea and continued exploration along the coast toward the north, through Bristol Bay, Norton Sound, and Bering Strait, until he was checked by an Arctic ice pack.

In 1789 Joseph Billings left Kamchatka in command of a Russian expedition, with orders to explore and map the coast visited by the fur hunters. He stopped at Unalaska and Kodiak on his way eastward to Prince William Sound, but contributed very little information regarding the geography of southwestern Alaska.

A more valuable series of coastal explorations was undertaken in 1826 , and in the next few years a careful survey of the northern coast of the Alaska Peninsula was made by Capt. Lütke. The southern coast of the Alaska Peninsula was mapped about this time by Vasilief. These expeditions were under the auspices of the Russian Government, and their work was the last exploratory work of importance in southwestern Alaska previous to the transfer of that land to the United States.

In 1848 Grewingk $^{1}$ compiled an admirable summary of all previous work of a geographic or geologic nature and assembled the facts con-

1 Grewingk, C., Beiträge zur Kenntniss der orographischen und geognostischen Beschaffenheit der Nordwest Küste Amerikas, mit den anliegenden Inseln, St. Petersburg, 1850. Contains geologic and other maps. 



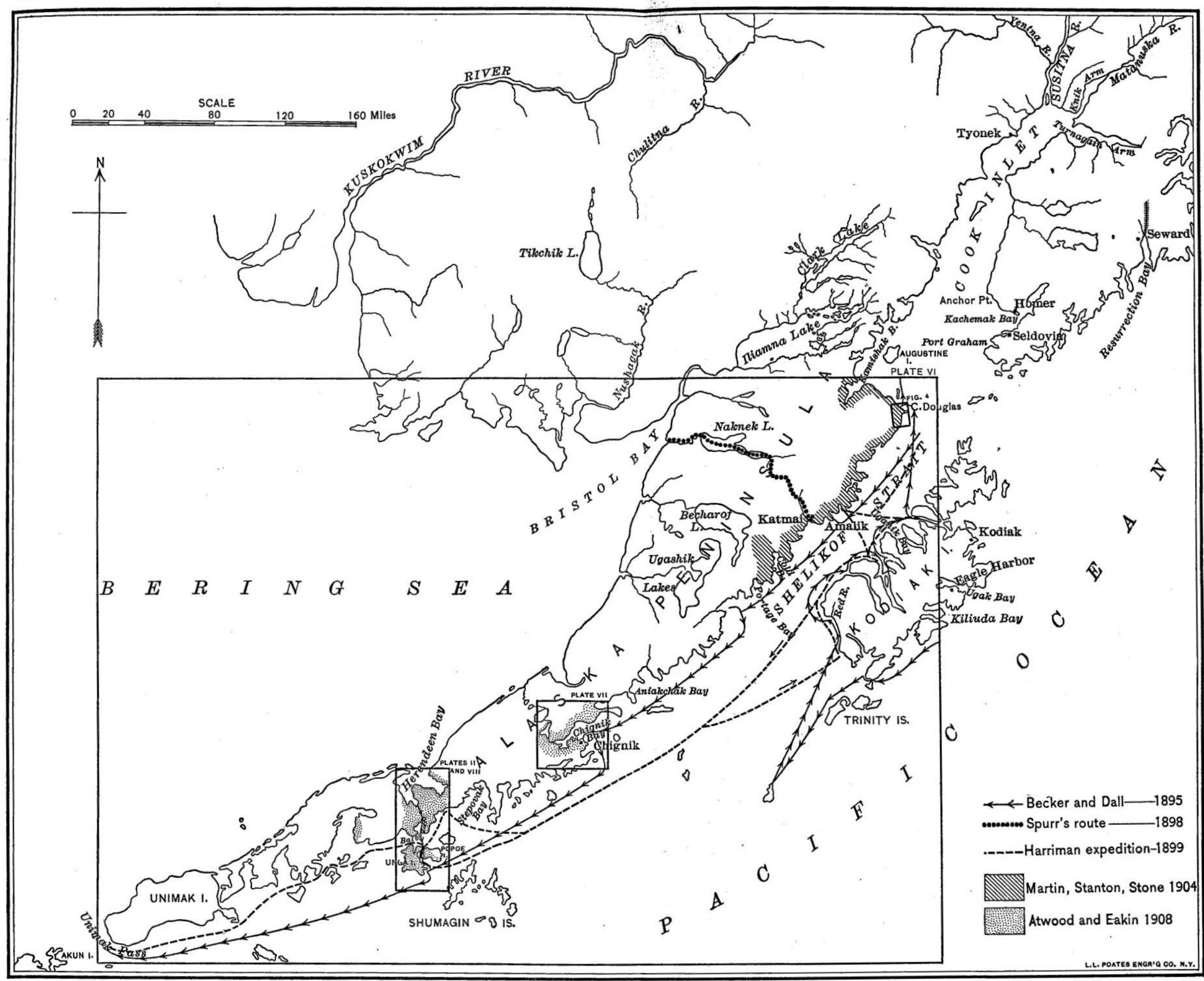



veniently in a single volume. Some noteworthy contributions to the paleontology of the peninsula were made by European scientists on the basis of specimens collected by Russians.

For some years after the purchase of Alaska by the United States, in 1867, little exploration work was done, though the Coast Survey began to chart the coast line. In the course of this work, Dall made valuable geologic observations. The first systematic geologic work in the Alaska Peninsula was undertaken in 1895 by Dall $^{1}$ and Becker. ${ }^{2}$ Dall was authorized by the United States Geological Survey to investigate and report on the coal and lignite deposits of Alaska, and these studies took him to southwestern Alaska. He visited the island of Unga, the coal fields near Herendeen and Chignik bays, and several other points, collecting in addition to all available data on the coal deposits much valuable information on the general geology of the peninsula. Becker at the same time visited southwestern Alaska and reported on the gold mines then in operation on Unga Island.

Late in the season of 1898 , Spurr and Post, ${ }^{3}$ under the auspices of the United States Geological Survey, crossed the peninsula from Naknek to Katmai. Spurr later prepared a reconnaissance geologic map of that portion of the peninsula based upon that work.

Emerson and Palache, ${ }^{4}$ who were members of the Harriman Alaska expedition of 1899, landed at several points on the Alaska Peninsula and neighboring islands, and made important contributions to the knowledge of the general geology of this district. Palache's studies on the shores of Stepovak Bay have been especially valuable to the writer in connection with recent work in that region.

In 1903 Martin ${ }^{5}$ examined oil fields near Cold Bay, and in his report refers to the general geology of that portion of the peninsula. T. W. Stanton, G. C. Martin, and R. W. Stone, as members of a United States Geological Survey party, spent the season of 1904 along the shores of the Alaska Peninsula between Cook Inlet and Unga. Their studies were devoted largely to the Mesozoic section ${ }^{6}$ and the coal deposits ${ }^{7}$ of the peninsula. Unpublished notes and maps by Stone on the Cape Douglas region have been used in the preparation of this report. During the course of the same work Martin visited the Shumagin Islands, and reported upon the gold

\footnotetext{
1Dall, W. H., Report on coal and lignite of Alaska: Seventeenth Ann. Rept. U. S. Geol. Survey, pt. 1, 1896, p. 807.

${ }^{2}$ Becker, G. F., Reconnaissance of the gold fields of southern Alaska: Eighteenth Ann. Rept. U. S. Geol. Survey, pt. 3,1898 , pp. 83-85.

${ }^{3}$ Spurr, J. E., A reconnaissance in southwestern Alaska in 1898: Twentieth Ann. Rept. U. S. Geol. Survey, pt. 7,1900 , pp. $43-263$.

1 Emerson and Palache, Harriman Alaska Expedition, vol. 4, 1904.

5 Martin, G. C., The petroleum fields of Pacific coast of Alaska: Bull. U. S. Geol. Survey No. $250,1905$.

${ }^{6}$ Stanton, T. W., and Martin, G. C., The Mesozoic section on Cook Inlet and Alaska Peninsula: Bull. Geol. Soc. America, vol. 16, 1905.

7 Stone, R. W., Coal resources of southwestern Alaska: Bull. U. S. Geol. Survey No. 259.1905, pp. $151-171$.
} 
deposits of Unga and Popof Islands. ${ }^{1}$ A. J. Collier ${ }^{2}$ in 1904 examined the gold-bearing quartz veins on Unalaska Island. In the same year Sidney Paige ${ }^{3}$ visited the Herendeen Bay coal field and prepared a report, which appeared in 1906.

The present report is based chiefly upon work during the season of 1908 by the writer, assisted by H. M. Eakin. The studies which had preceded our work aided us in locating points of special interest and in anticipating the general geologic conditions to be dealt with. The results of these earlier expeditions have been freely used in describing the general geologic conditions on the peninsula. During the season Mr. Eakin completed a reconnaissance topographic map of a portion of the peninsula in the vicinity of Balboa and Herendeen bays, including the island of Unga (Pl. II), and later prepared a similar map for the region adjoining Chignik Bay (PI. VII,p. 40). During the same period the writer prepared a geologic map of each region that was surveyed topographically, and the field work placed on sketch maps has been transferred to the topographic maps with as much accuracy as possible (Pls. VII and VIII, pp. 40 and 42). In addition to the districts in which detailed work was done during the season, a few other points of especial interest were visited, and mention of these points will appear in the course of the report.

\section{ACKNOWLEDGMENTS.}

The writer wishes to acknowledge his indebtedness to Messrs. Stanton, Knowlton, and Dall, of the Geological Survey, for their prompt reports on the paleontological material which was brought in from this region and for the cordial conferences through which they have assisted in completing these studies. The writer is also indebted to Adolph Knopf for a petrographic study of certain rock specimens obtained in this field. Mr. Eakin was a most efficient and loyal assistant throughout the season.

Life in this part of Alaska was made especially pleasant at times by the cordial hospitality of Mr. C. A. Fletcher, superintendent of the Apollo mine at Unga, and by the respect accorded our party at the Herendeen Bay coal camp, at Coal Harbor, and at other settlements in that region. In the Chignik Bay field we were most cordially and helpfully assisted by Mr. G. M. Landsberg, superintendent at one of the salmon canneries. Through his kind offices we were enabled to visit many points that we could not otherwise have reached and to prosecute our work with greater ease and safety than we could have provided. The officers of the steamship Dora accommodated our party as well as could be expected, and facilitated our

\footnotetext{
1 Martin, G. C., Gold deposits of the Shumagin Islands: Bull. U. S. Geol. Survey No. 259, 1905, pp. 100-101.

${ }^{2}$ Collier, A. J., Auriferous quartz veins on Unalaska Island: Bull. U. S. Geol. Survey No. 259, 1905.

3 Paige, Sidney, The Herendeen Bay coal field: Bull. U. S. Geol. Survey No. 284, 1906, pp. 101-108. '
} 


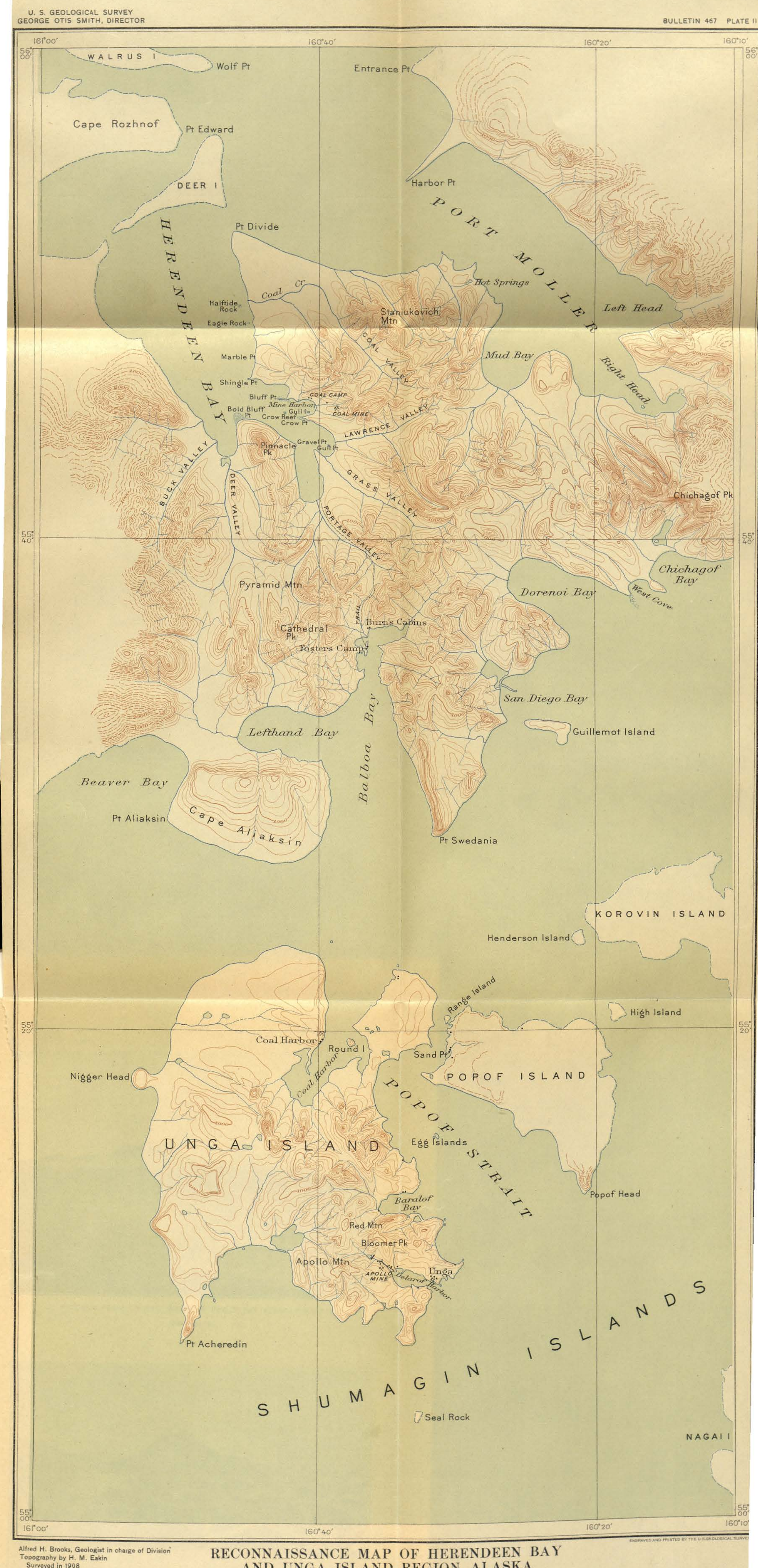

RECONNAISSANCE MAP OF HERENDEEN BAY

AND UNGA ISLAND REGION, ALASKA

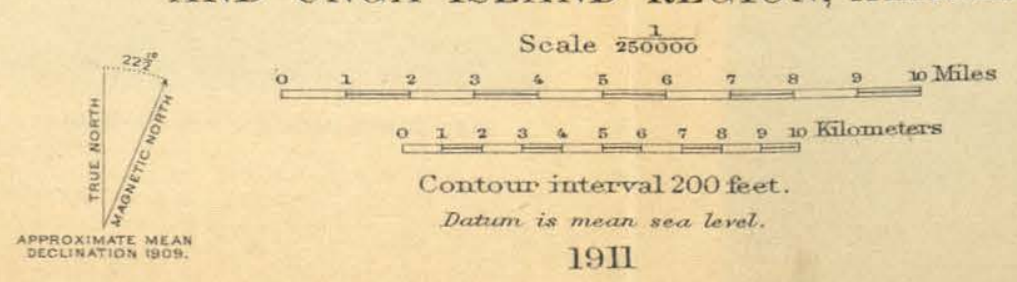





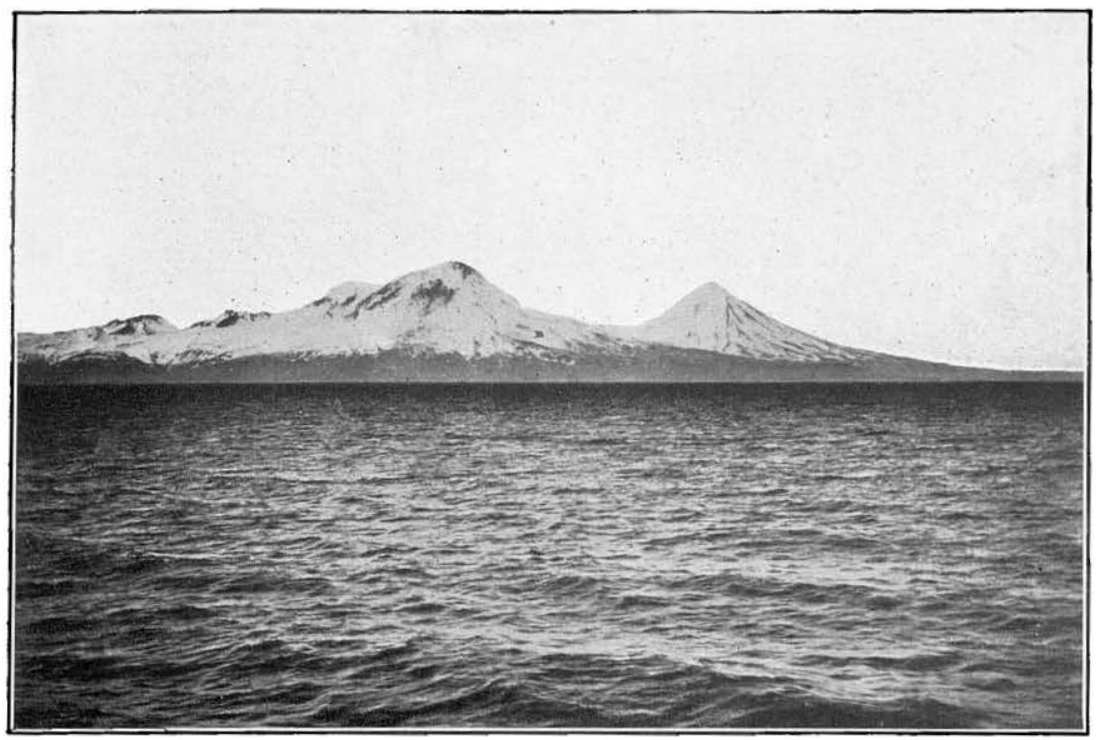

A. VOLCANIC PEAKS ON WEST SHORE OF PAVLOF BAY, ALASKA PENINSULA.

See page 13.

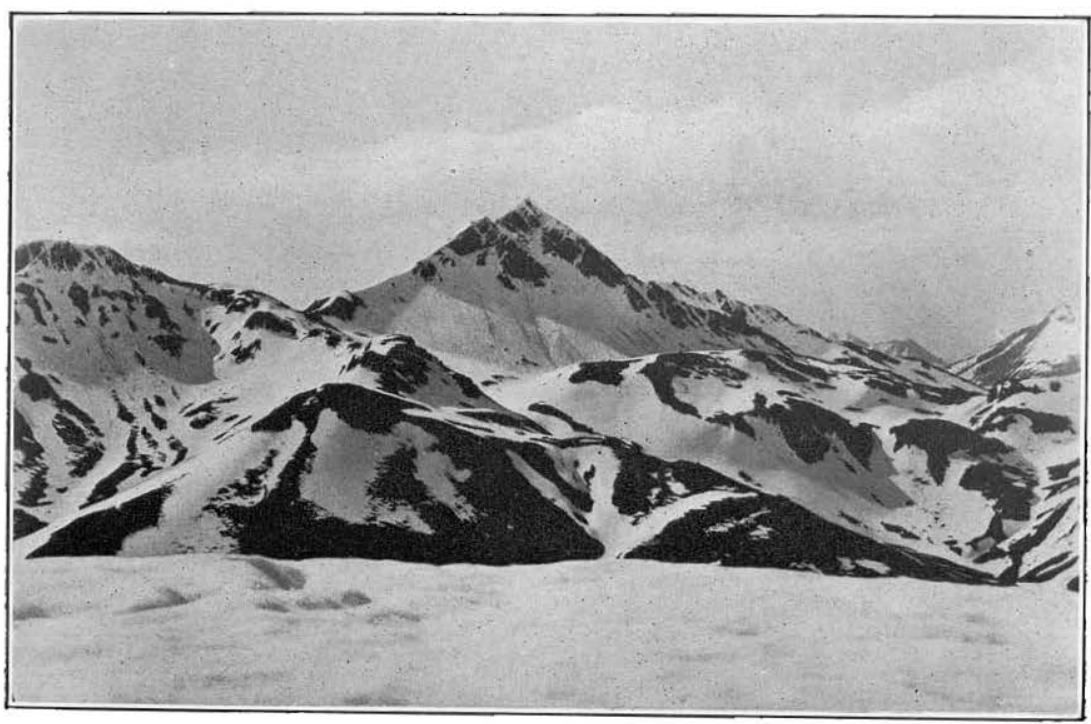

B. CATHEDRAL PEAK, ONE OF THE HIGHER SUMMITS IN THE ALEUTIAN RANGE NEAR BALBOA BAY

See pages 13,63 . 



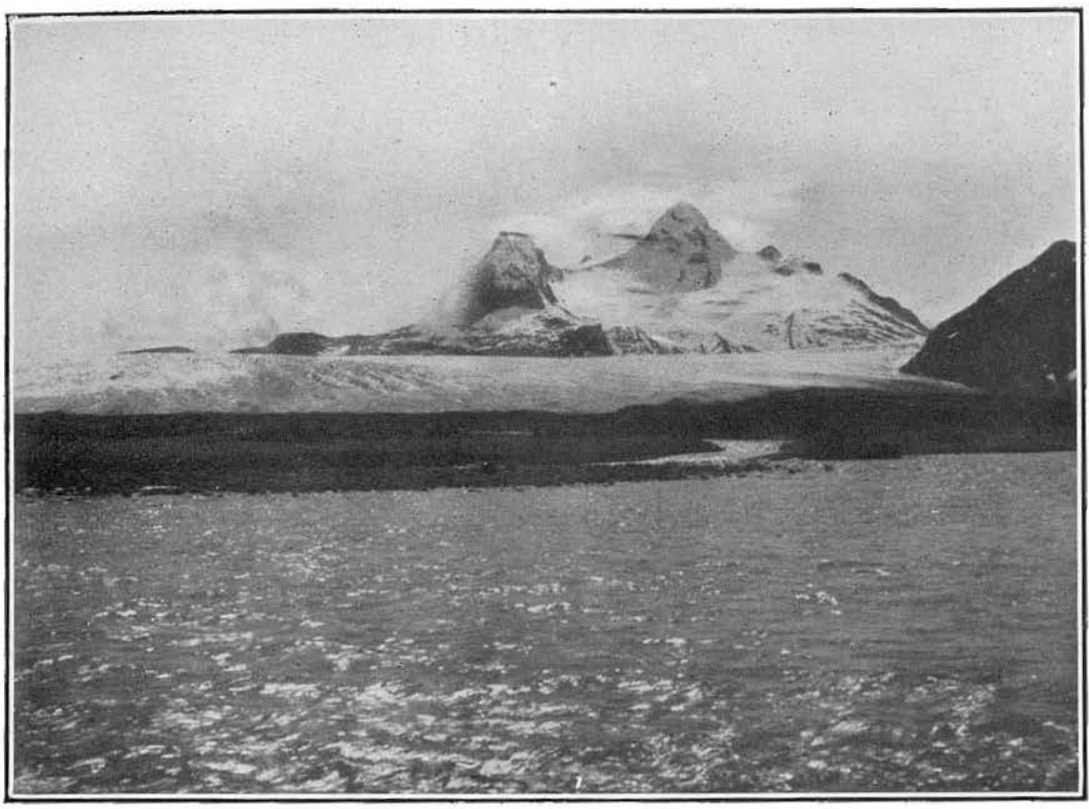

A. MOUNTAINS AND GLACIERS WEST OF CAPE DOUGLAS.

Mount Douglas, the highest peak in the picture, is about 7,000 feet above sea level. See page 13.

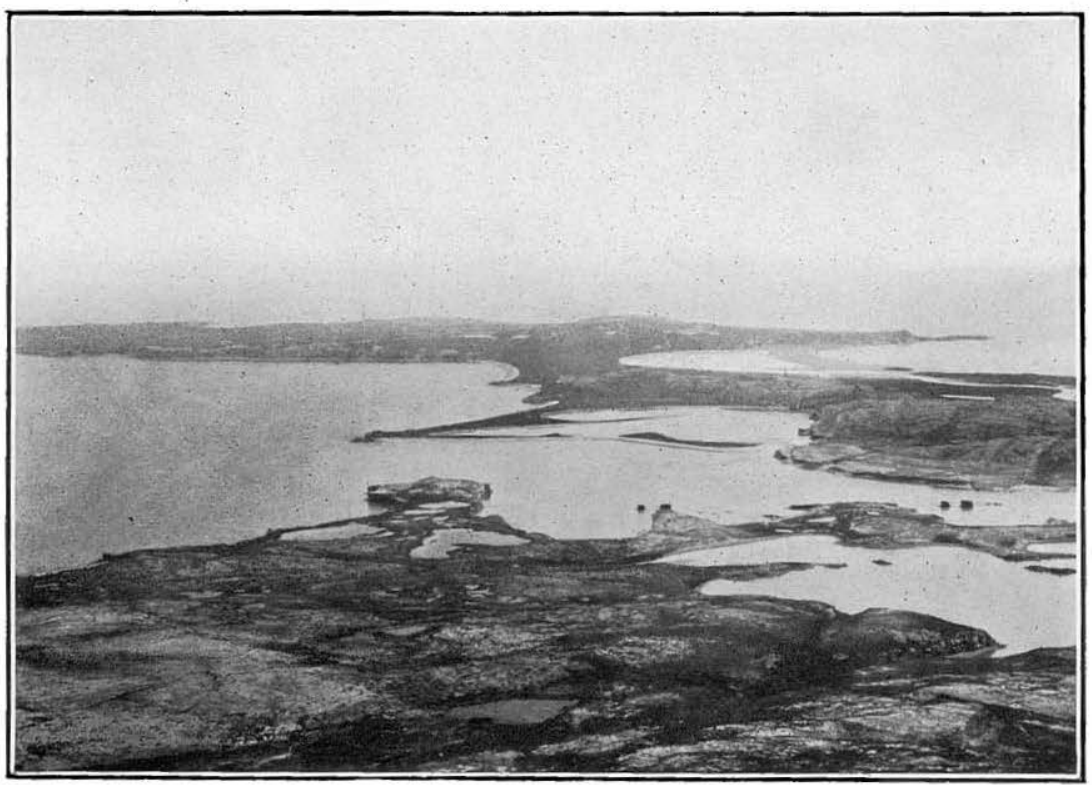

$B$. VIEW OF CAPE DOUGLAS FROM THE WEST.

The outer portion was an island which has been tied to the mainland by a sand bar. See pages $75,93$. 

movements whenever it was possible: Since leaving the field the writer has become indebted to Messrs. F. R. Philbrick and R. A. Foster, engineers at the Herendeen Bay mines, for maps, charts, drill records, and numerous photographs, all pertaining to the Herendeen Bay coal field.

\section{CHARACTER OF THE COUNTRY.}

GEOGRAPHY.

MOUNTAINS.

A chain of mountains known as the Aleutian Range runs through the central portion of the Alaska Peninsula. To the northeast these mountains reach elevations of approximately 5,000 feet above sea level; to the southwest they decline gradually to between 2,000 feet and 3,000 feet in the neighborhood of Chignik and Herendeen Bays. Still farther west the general crest line of the range declines, but there are isolated volcanic peaks of conspicuous elevation (Pl. III, $A$ ). The Aleutian Range has the rugged features characteristic of most young mountains, a condition which, together with the perennial snow fields on the upper slopes, makes the range one of striking scenic beauty (Pl. III, $B$ ). The peaks are sharply defined, the valleys broad; open, and $U$-shaped, and the intervalley ridges in most places narrow. Along the summits in the northern portion of the peninsula are several large alpine glaciers. West of Cape Douglas a few glaciers reach nearly to sea level (Pl. IV, $A$ ), and one glacier on the west slope of Pavlof Mountain is fully 10 miles long. To the southwest, in and near the crest line of the range, large, open, amphitheatral basins have been excavated by the glaciers that formerly existed there. These basins have the characteristic cirquelike form, with rather even floors bounded by precipitous walls.

The lower 300 or 400 feet of the mountain slopes are clothed with grasses, mosses, and irregularly scattered bunches of alder bushes. Above this zone, where the mountain slopes are not too steep for vegetation, they are imperfectly covered by mosses and short grass. In this latter zone, and extending even higher, there is commonly an abundance of dwarfed flowering plants. Still higher, there is a marked areal increase in bare rock surfaces.

On the west shore of Pavlof Bay there are two conspicuous cones (Pl. III, A), the larger of which is appropriately known in that vicinity as Smoking Mountain. This peak rises to an elevation of 8,900 feet. On Unimak Island, Shishaldin, Pogromni (6,500 feet), and Isanotski peaks $(8,032$ and 8,088 feet) are conspicuous volcanic mountains. The mountains of the islands south of the Alaska Peninsula are rugged and reach in some places elevations of about 2,500 feet. 


\section{LOWLANDS.}

A lowland of varying width extends northwest from the Aleutian Range to the shores of Bristol Bay. Its greatest width is about 20 miles. This lowland belt is continuous from the northeast terminus of the peninsula to a point not far west of Pavlof Bay, or within about 50 miles of the eastern end of Unimak Island. The topography of this lowland belt is that of a plain varied by low morainic hills and narrow valleys. It is a tundralike country, covered with a luxuriant growth of grasses and mosses. Among the morainic hills are shallow depressions containing lakes or marshes.

Most of the larger valleys in the peninsula have bottom lands, nearly at sea level. At the heads of all the larger bays where detailed mapping has been done are extensive meadowlands. These lowland areas, whether in the larger valleys or at the heads of bays, support a growth of grass which in places reaches a height of 5 feet. On the islands where detailed work has been done there are also small lowland areas associated with the larger valleys or marginal portions of the lands. The northwest portion of Unga Island has a gently rolling topography, the highest point being not more than 600 feet above the sea.

\section{COASTS.}

The Pacific Ocean side of the Alaska Peninsula presents a bold, rugged shore line, bordered at many points by steep cliffs (Pl. V). It is indented by fiordlike inlets, separated from each other by rocky headlands. The islands bordering the coast appear, in places, to be seaward continuations of the headlands. Along this coast and associated with the steep cliffs are overhanging ledges, arched rocks, sea caves, rock pillars, and balanced rocks-features such as are developed on rock-bound coasts exposed to the vigorous action of ocean waves (Pls. IX, $B$, p. 62, and XII, $A$, p. 92). At several places along this southeast coast of the peninsula are sea terraces, in part cut in solid rock and in part composed of loose material that has been handled by the waves and the undertow. These sea terraces indicate that the sea once stood at a higher level relative to the land.

The northwest coast, bordering Bristol Bay, is in striking contrast to that bordering the Pacific Ocean. From a point near the head of Bristol Bay southwest to within a few miles of the western terminus of the peninsula the coast line is low. It is the margin of the northwest coastal plain of the peninsula and marks the line to which the waters reach, as they lap upon a plain which extends from the base of the mountains seaward and somewhat beyond the present shore line. Low sand bars and islands border the coast on this side of the peninsula, shutting in shallow lakes and lagoons. Sand dunes, some of which are 50 feet in height, are found on the isląnds and at places 
on the mainland. Near the head of Bristol Bay the northwest margin of the peninsula is marked by a low sea cliff, developed by the work of the waves as they have encroached upon the lowland belt.

DRAINAGE.

As the peninsula is narrow, all the streams are short. The main divide is near the crest line of the Aleutian Range and part of the drainage goes to the Pacific Ocean and part to Bristol Bay. The streams emptying into the Pacific Ocean flow through canyonlike valleys until they reach the meadowlands at the heads of bays or fiords. On the northwest or Bristol Bay side, the drainage is delayed in many places in small lakes or ponds. Near the northeast end of the peninsula, among the mountains, are four large lakes-Kukaklek, Naknek, Becharof, and Ugashik-all of which receive their waters from the surrounding mountains and drain westward into Bristol Bay. A chain of lakes extends well into the mountains from the head of Chignik Bay, and from the northern end of this drainage area it is but a short portage over a lowland area to the drainage which flows into Bristol Bay. The route is commonly followed by natives with small boats.

\section{CLIMATE.}

The Alaska Peninsula is in about the same latitude as the British Isles, and except in the northern part does not suffer from severe climatic conditions. The rainfall varies from about 100 inches annually in the western portion of the peninsula to probably about 20 inches on the shores of Shelikof Strait. At Coal Harbor (Unga Island) the average annual rainfall is 49 inches. Snow covers the entire area during the winter months, even to sea level, and remains until late in March. By the latter part of May the snows have commonly left the lowlands and the lower portions of the mountain slopes. During the summer months, from June to September, inclusive, much of the weather is delightful. Though rains may be frequent, they are usually not so heavy as to interfere with out-of-door work. The mean temperature from May to October varies from $49.1^{\circ}$ at Kodiak, to $45.5^{\circ}$ at points farther west. 
Weather records made by volunteer observers in southwestern Alaska. $a$

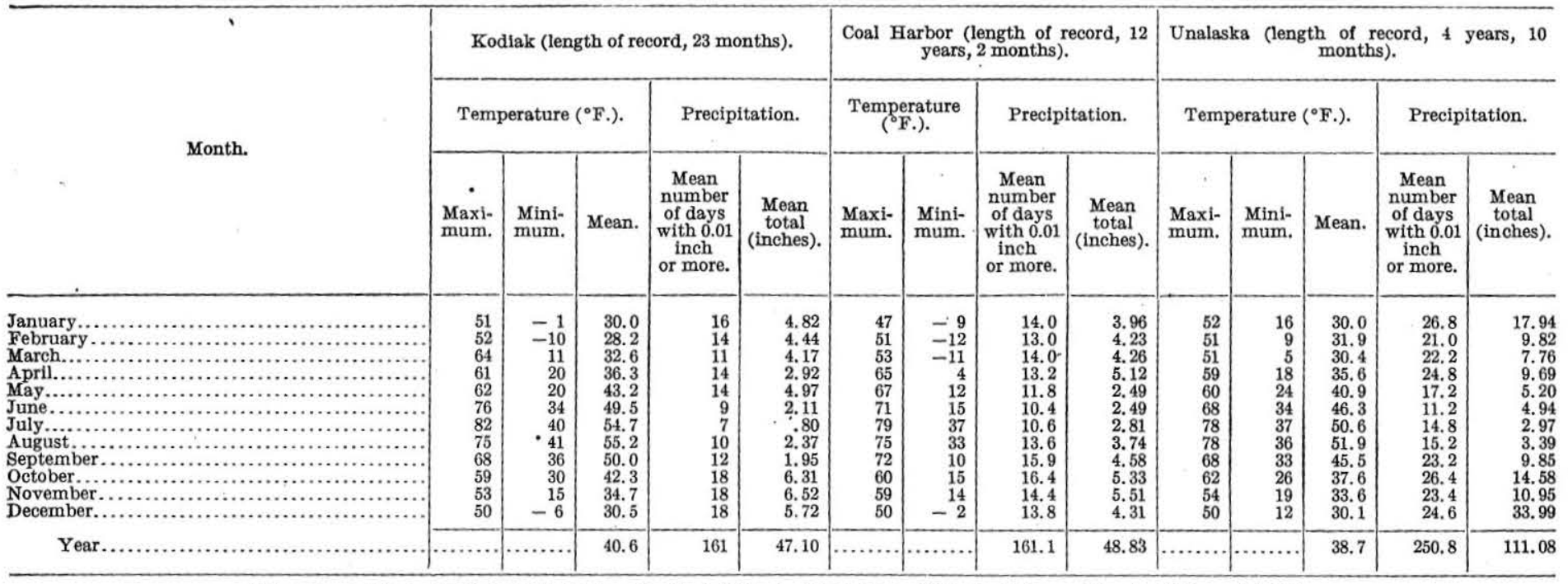

a Taken in part from climatological table by Cleveland Abbe, jr. (Prof. Paper U. S. Geol. Survey No. 45, 1906, pp. 158-170). 
Weather record for Mine Harbor, Herendeen Bay, Alaska.

[Records made by volunteer weather observers.]

\begin{tabular}{|c|c|c|c|c|c|c|c|c|c|c|}
\hline \multirow{3}{*}{ Months. } & \multicolumn{5}{|c|}{ Temperature $\left({ }^{\circ} \mathrm{F}.\right)$. } & \multicolumn{5}{|c|}{ Precipitation. } \\
\hline & \multirow{2}{*}{$\begin{array}{l}\text { Maxi- } \\
\text { mum. }\end{array}$} & \multirow{2}{*}{$\begin{array}{l}\text { Mini- } \\
\text { mum. }\end{array}$} & \multicolumn{3}{|c|}{ Mean. } & \multirow{2}{*}{ Clear. } & \multirow{2}{*}{$\begin{array}{l}\text { Clouds, } \\
\text { rain, or } \\
\text { snow. }\end{array}$} & \multirow{2}{*}{ Rain. } & \multicolumn{2}{|c|}{ Snow. } \\
\hline & & & $\begin{array}{l}\text { Maxi- } \\
\text { mum. }\end{array}$ & $\begin{array}{l}\text { Mini- } \\
\text { mum. }\end{array}$ & Mean. & & & & $\begin{array}{l}\text { Maxi- } \\
\text { mum. }\end{array}$ & $\begin{array}{l}\text { Mini- } \\
\text { mum. }\end{array}$ \\
\hline \begin{tabular}{l}
\multicolumn{1}{c}{1902.} \\
October................. \\
November......... \\
December........
\end{tabular} & $\begin{array}{l}55 \\
47 \\
45\end{array}$ & $\begin{array}{r}23 \\
12 \\
-\quad 7 \\
\end{array}$ & $\begin{array}{l}45.0 \\
38.9 \\
25.7\end{array}$ & $\begin{array}{l}33.6 \\
28.2 \\
14.0\end{array}$ & $\begin{array}{l}39.8 \\
34.3 \\
20.7\end{array}$ & $\begin{array}{r}\text { Days. } \\
7 \\
5 \\
7\end{array}$ & $\begin{array}{r}\text { Days. } \\
24 \\
25 \\
24\end{array}$ & $\begin{array}{r}\text { Inches. } \\
6.15 \\
6.45 \\
.89 \\
\end{array}$ & $\begin{array}{r}\text { Inches. } \\
2 \\
8 \\
12\end{array}$ & $\begin{array}{l}\text { Inches. } \\
\ldots \ldots \ldots \\
\cdots \ldots \\
\cdots \ldots\end{array}$ \\
\hline 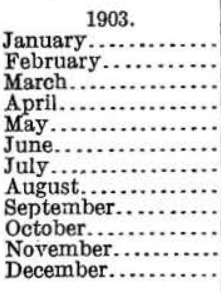 & $\begin{array}{l}38 \\
44 \\
49 \\
45 \\
53 \\
65 \\
68 \\
68 \\
61 \\
55 \\
40 \\
43\end{array}$ & $\begin{array}{r}-15 \\
-17 \\
15 \\
15 \\
30 \\
32 \\
38 \\
40 \\
31 \\
18 \\
15 \\
13\end{array}$ & $\begin{array}{l}22.7 \\
34.5 \\
39.2 \\
38.5 \\
45.6 \\
54.1 \\
55.6 \\
57.4 \\
52.5 \\
42.9 \\
33.7 \\
34.5\end{array}$ & $\begin{array}{r}6.8 \\
21.1 \\
23.6 \\
26.2 \\
33.6 \\
40.4 \\
45.2 \\
45.8 \\
42.3 \\
30.3 \\
23.8 \\
25.5\end{array}$ & $\begin{array}{l}13.9 \\
27.8 \\
31.4 \\
32.4 \\
39.6 \\
47.3 \\
50.4 \\
51.6 \\
47.4 \\
36.6 \\
28.8 \\
30.0\end{array}$ & $\begin{array}{r}10 \\
5 \\
11 \\
5 \\
6 \\
5 \\
4 \\
5 \\
2 \\
2 \\
2 \\
4\end{array}$ & $\begin{array}{l}21 \\
23 \\
20 \\
25 \\
25 \\
25 \\
27 \\
26 \\
28 \\
29 \\
28 \\
27\end{array}$ & $\begin{array}{l}2.36 \\
6.61 \\
1.00 \\
2.25 \\
2.59 \\
1.01 \\
2.51 \\
4.25 \\
5.10 \\
3.97 \\
2.60 \\
5.92\end{array}$ & 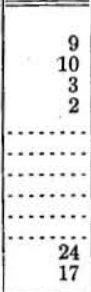 & 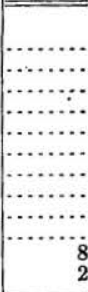 \\
\hline & ........ & $\cdots \cdots$ & 42.6 & 30.4 & 36.5 & 61 & 304 & 40.17 & & ......... \\
\hline 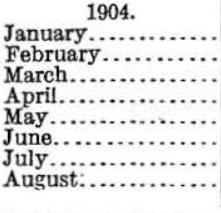 & $\begin{array}{l}40 \\
41 \\
44 \\
45 \\
55 \\
58 \\
65 \\
63\end{array}$ & $\begin{array}{r}-2 \\
-7 \\
4 \\
3 \\
22 \\
31 \\
37 \\
39\end{array}$ & $\begin{array}{l}30.1 \\
28.8 \\
31.9 \\
34.0 \\
44.7 \\
49.5 \\
53.7 \\
53.0\end{array}$ & $\begin{array}{r}17.3 \\
13.1 \\
15.8 \\
21.4 \\
29.8 \\
37.3 \\
41.6 \\
43.4\end{array}$ & $\begin{array}{l}23.7 \\
21.5 \\
23.9 \\
27.7 \\
37.3 \\
43.4 \\
47.7 \\
48.1\end{array}$ & $\begin{array}{l}7 \\
8 \\
6 \\
1 \\
5 \\
2 \\
1 \\
2\end{array}$ & $\begin{array}{l}24 \\
21 \\
25 \\
29 \\
26 \\
28 \\
30 \\
29\end{array}$ & $\begin{array}{r}3.00 \\
.49 \\
.30 \\
1.42 \\
.81 \\
1.30 \\
3.79 \\
4.78\end{array}$ & 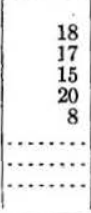 & 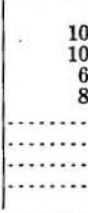 \\
\hline
\end{tabular}

Mine Harbor frozen Dec. 18, 1902, to May 6, 1903; Dec. 29, 1903, to May 26, 1904; Jan. 3 to May 25, 1905; Jan. 15 to Mar. 17, 1906.

Fresh snows are commonly seen on the mountain tops in the later part of August, and preparation for the winter season should not be postponed beyond the last of September. During the winter the snowfall, as reported unofficially, varies from 10 to 30 feet in depth. The mean winter temperature on the Alaska Peninsula is about $30^{\circ}$. The minimum temperatures recorded at the stations where observations have been systematically made are: Kodiak $-6^{\circ}$, Coal Harbor $-12^{\circ}$, Herendeen Bay $-17^{\circ}$. On some of the islands south of the peninsula it is reported that cattle graze throughout the year. During the winter the frequent storms on the Pacific shore are exceedingly dangerous to small craft. Bristol Bay freezes over during the winter and is not usually navigable until late in April.

\section{VEGETATION.}

Small conifer trees grow in the northeastern portion of the Alaska Peninsula as herein defined and on Kodiak Island. The trees are fewer in number and smaller in size to the west and disappear altogether in the vicinity of Naknek Lake, where the largest forms of $90054^{\circ}-$ Bull. $467-11-2$ 
plant life are alder bushes. These bushes, in places, reach a height of 15 feet, but are more commonly only 6 or 8 feet high. Southwest from Naknek Lake to the end of the peninsula and to the most westerly of the Aleutian Islands there are no trees. The alder bushes are as a rule confined to the lower 500 feet of the mountain slopes and are unevenly distributed. Small willow bushes border some of the streams and grow in the lowland areas. The dominant and conspicuous form of vegetation in this region is grass, which grows luxuriantly in the lowland areas and clothes the mountain slopes, where the surfaces are not too steep or too rugged to permit vegetation to get a footing, to an elevation of about 1,000 feet above sea level. Above the grass-covered areas, even to the tops of the mountains, are occasional small bunches of flowering plants, some patches of short grass, and some moss. The coastal plain on the northwest side of the peninsula is a tundra covered with moss and grass, and mosses and grasses grow luxuriantly over all but the more rugged portions of the islands south of the peninsula. Small areas of land have been cultivated for vegetable gardens at various places in this portion of Alaska, but no more extensive agriculture has as yet been undertaken. The luxuriant growth of grasses in the broad valley bottoms suggests the possibility of raising sufficient winter fodder for cattle, and the grass-covered hillsides would serve as summer ranges.

\section{SETTLEMENT.}

Beginning on the northeast the ports at which the United States mail steamer usually calls are Cold Bay, Chignik Bay, Unga (on Unga Island), Sand Point (on Popof Island), Coal Harbor (on Unga Island), Belkofski, Unalaska, and Nushagak. (See Pl. VI, in pocket.) This last port is at,the head of Bristol Bay, a little northwest of the peninsula proper, and the mail steamer calls there during the summer months only. At Cold Bay there has been only one white settler during the last few years. At Chignik Bay there are two salmon canneries, a post office, and a native village. During the summer season between 400 and 500 men are employed in the canneries, and a few prospectors are also at work in this region. At Unga there are a post office and a small native village. Some cod fishing is carried on from Unga and at Baralof Harbor, a few miles north of the village of Unga. Sand Point, at the northwest end of Popof Island, is a local trading center and a post office, while Pirate Cove, on the north shore of Popof Island, is a fishing station. At Coal Harbor, on the north end of Unga Island, there is a small settlement of white people. Unalaska is a local trading center and also a coaling station for United States revenue cutters and for steamers engaged in Bering Sea fisheries or trade. Nushagak is an important fishing station, and hundreds of men are engaged during the summer in catching salmon 
and in operating the canneries at this port. The winter population, however, consists of scarcely more than a dozen white people and a small number of natives.

A few white people live at a distance from the settlements. At Herendeen Bay, on the north side of the peninsula in about the same longitude as Unga, there is a coal-mining camp, at which there is usually at least one white man. There are white people on the shores of Pavlof Bay, on certain of the islands south of that bay, on some of the Shumagin Islands southeast from Unga, and on Mitrofania Island. In addition to the native villages already mentioned, a few natives live on Bear River, a short distance east of Port Moller, at Port Heiden, Ugashik, Ugaguk, Naknek, and at several other points along the north side of the peninsula. There are small native settlements at the head of Naknek Lake and at Katmai, on the Pacific Ocean side. The entire resident population probably includes not more than 50 whites and 1,000 natives.

\section{COMMERCIAI DEVELOPMENT.}

The known mineral resources of the Alaska Peninsula include coal, petroleum, gold, and copper. Their distribution is shown on Plate VI (in pocket). Of the coal fields, only three are known to be of commercial importance-the Unga Island field, the Herendeen Bay field, and the Chignik Bay field.

Unga Island coal field.-Previous to 1882 there was no mining in this field except by Russians, who are reported to have taken some coal from outcrops near the beach. Between 1882 and 1884 a company was engaged in mining at this locality and is said to have kept 20 men at work throughout that period and to have supplied with fuel small steamers engaged in seal hunting. Some of the coal was used for domestic purposes, and two cargoes, amounting to about 700 tons, are reported to have been sent to San Francisco in 1883. The property is now under the control of the Tide Water Consolidated Co. Several drifts have been opened and one mine put into operation on a shipping basis. Bunkers have been built about 100 feet from the shore, and a steel conveyor connects them with the mine. The developed coal bed outcrops. about 200 feet above tidewater.

Herendeen Bay coal field.-The presence of coal in the Herendeen Bay region has been known for a number of years. Several attempts have been made toward its development, but little coal has yet been mined. The first exploitation of the field was undertaken in 1880 by a corporation known as the Alaska Mining and Development Co. Two drifts were run, one about 200 feet; the other about 300 feet in length, on a coal bed of 4 feet average thickness. The coal was brought to the water front by a steam motor on a small tramway, and several hundred tons were taken out in 1890, of which amount the U. S. S. 
Albatross used between 200 and 300 tons. $^{1}$ At that time there was no immediate market for the coal, as the Western States and Territories were fully supplied from the Washington and Vancouver mines. The field was therefore abandoned and no further work was done until 1898, when C. A. Johnson relocated the coal land and started what is known as the Johnson tunnel. The property passed, in 1902, into the hands of a company, which, however, did very little.work, and forfeited all its rights in 1904. The present claimants have made surveys of the field and have done some careful prospecting, including a small amount of core-drill work. They have also surveyed a railway route from Herendeen Bay to Balboa Bay and completed a chart of the Balboa Bay Harbor.

Chignik Bay coal field.-Coal was discovered in the bluff of Chignik River in $1885,{ }^{2}$ but active mining was not undertaken until 1893. Since that time the Alaska Packers' Association has operated its mines to procure fuel for the cannery on Chignik lagoon and for the steamers engaged in the fisheries. Short prospecting tunnels have been driven on the coal seams on Whaler's Creek, in Thompson Valley, and a few miles inland from the head of Hook Bay.

Coal developments at other points on the peninsula have been relatively insignificant. On the south side of the peninsula, just east of Pavlof Bay, a little mining of lignite was carried on during the season of 1908 for local consumption. At the other localities where coal is known to exist little more than preliminary prospecting has been done.

Petroleum developments. - Some drilling has been done in the vicinity of Cold and Dry bays, where oil seepages were discovered. In 1902 and 1903 work was carried on at Dry Bay, but the field was afterwards abandoned. In 1903 and 1904 several wells were drilled at Cold Bay, but as they yielded no flow of oil, drilling was discontinued.

Gold. ${ }^{3}$-Placer gold was discovered on Popof Island in the summer of 1904, and it is reported that gold amounting in value to about $\$ 12,000$ was taken from these beach placers in 1904 and 1905 . Little work has been done on this beach since 1905. Four lode claims were staked on the hills immediately adjoining the beach placers in 1908, and on these claims short prospecting tunnels, a few shallow shafts, and one surface crosscut were opened.

Gold-bearing quartz ledges have been found at a number of places on Unga Island. In the southeastern part of the island, about 1 mile from the head of Delarof Harbor and 4 miles from the town of

${ }_{1}^{1}$ Dall, W. H., Coal and lignite of Alaska: Seventeenth Ann. Rept. U. S. Geol. Survey, pt. 1, 1896, p. 805.

2 Idem, p. 802.

${ }^{3}$ More detailed information regarding gold prospects on Popof Island is given on pages 125 and 131 of this report. 
Unga, are located the Apollo and Sitka mines. A third mine has been opened on the Shumagin group of claims near the head of Baralof or Squaw Harbor. Several locations for gold lodes have been made on the ridge south of the Apollo mine, in the valley west of the Shumagin mine, and at points about 2 miles south of Coal Harbor.

The Apollo Consolidated mine of Unga Island was on a productive basis from 1891 to 1904, and was reopened during the summer of 1908 , when 40 of the 60 stamps in the mill were put into operation and ore that had already been mined was run through the mill. The occurrence of gold at this locality was described by Becker ${ }^{1}$ in 1895 and later by Martin, ${ }^{2}$ who visited the Apollo mine in 1904 and gathered some additional data.

The Sitka and Shumagin mines have not become productive, and during the season of 1908 no work was done in the Shumagin mine and but little in the Sitka mine. Several gold prospects have been located in the vicinity of Chignik Bay and others near the head of Port Moller, but very little development work has been done at either place.

Copper.--There are no copper mines in southwestern Alaska, but several locations have been made for copper at Prospect Bay and on the east shore of Balboa Bay.

Other resources.-In addition to mineral wealth, the Alaska Peninsula has other important resources. The red fox is most common of the fur-bearing animals of the region, although some Arctic hare are found. Some of the smaller islands south of the Peninsula are used as fox ranches. The brown bear are still somewhat common, and the hides are of some commercial value. Large herds of caribou furnish an abundant supply of fresh meat. Cod fishing stations have been established at several points on the Shumagin Islands and farther west. There are two salmon canneries near Chignik Bay, and others on the north side of the peninsula near the head of Bristol Bay. Several salmon-salting stations have been established along the north shore and each year hundreds of tons of salmon are salted down and shipped to the States at the close of the season. The sea otter that first attracted the Siberian hunters to this coast have become very scarce. During the summer season of 1908 the writer saw three sea otter skins that had been procured by the natives. These three raw skins were valued by fur traders at $\$ 700$.

${ }^{1}$ Becker, G. F., Reconnaissance of the gold fields of southern Alaska: Eighteenth Ann. Rept. U. S. Geol. Survey, pt. 3, 1898, pp. 12, 83-85.

2 Martin, G. C., Gold deposits of the Shumagin Islands: Bull. U. S. Geol. Survey No. 259, 1905, pp. 100-101. 


\section{TRANSPORTATION.}

At present there is but one regular passenger steamer that visits the ports southwest of Cook Inlet and west of Kodiak. This steamer, which makes one trip a month, connects with regular steamers from Seattle at Seward, and on its westward journey calls at Seldovia and Kodiak before leaving for ports on the peninsula. Private yachts or launches may sometimes be chartered at Seward or Kodiak for the journey west to points on the peninsula or neighboring islands. There is occasionally an opportunity to go direct from Seattle to Dutch Harbor or Unalaska on a steamer bound for Nome, and to make connections at either of those ports for points on the peninsula.

Travel from point to point in the western part of the region is most convenient by means of coasting vessels or other small boats. The large bays, several of which reach well into the central portion of the peninsula, make it possible to go by water to within a few miles of almost any point in the western part of the area. In the northeastern portion the routes of travel are largely determined by the drainage lines, and advantage is usually taken of the large lakes to reach points in this part of the peninsula. It is not difficult to go on foot over the greater part of the peninsula, but a few of the higher peaks are rugged and to climb to their summits would demand some skill. The lower slopes are gentle and their clothing of mosses and grasses helps to make travel over them relatively easy. It would be possible to work with a pack train over much of this country. Horses are now in use over the trail from Balboa to Herendeen Bay, and these horses have traveled over many of the hills in the Herendeen Bay coal field.

There are good harbors at Hook Bay (Pl. XIII, A, p. 108), at Anchorage Bay (Pl. XI, B, p.86 ), an arm of Chignik Bay, and in Balboa Bay, near Sand Point. Small harbors are numerous. Prospect Bay, a few miles west of Chignik Bay, offers shelter behind a small hook (fig. 18, p. 129) for a large vessel or for several small boats. Harbor conditions at Unga (Pl. XI, $A$, p. 86) are favorable except during southeast storms. Baralof and Coal harbors, on Unga Island, furnish good shelter and good anchorage. Herendeen Bay may be entered by small ocean-going vessels, and anchorage conditions near the head of the bay are good. Port Moller is so shallow that most of the bottom is exposed at low tide.

The peninsula is often crossed from Portage Bay to Ugashik, part of the route being by water, and may be crossed from Katmai by way of Naknek Lake to Naknek, or from Cold Bay by way of Becharof Lake to Ugaguk. There is a route across the peninsula from the head of Chignik'Bay, by way of the Chignik Lakes and a short portage, to the drainage of the north side of the peninsula. The head of Port 
Moller is but 8 miles away, and may be reached from a point in Stepovak Bay by a trail leading over a low pass. From the head of Balboa Bay there is a good trail to the head of Herendeen Bay, a distance of 9 miles over a pass about 400 feet above sea level. Unga Island may be crossed in almost any direction on foot. Broad, open valleys make travel from one part of the island to another relatively easy.

\section{GEOLOGY.}

\section{GENERAL FEATURES.}

AGE AND SUCCESSION OF THE ROCKS.

The geologic history of the Alaska Peninsula, so far as it has been determined, is limited to Mesozoic and Cenozoic times. Some granitic rocks in the northwestern portion of the province are known to be of pre-Upper Jurassic age, but no rocks on the peninsula are definitely known to be pre-Triassic. Since the opening of Mesozoic time sedimentation has been going on in some portion of the peninsula during each of the great geologic epochs, with the possible exception of the Pliocene and the Oligocene. The Triassic is represented in at least one locality. Large areas of Jurassic sediments represent at least portions of the Middle Jurassic and the Upper Jurassic series. The Lower Cretaceous and the Upper Cretaceous are represented. There are also Eocene, possibly some Oligocene, and certainly some Miocene sediments in the province. From the Eocene epoch to the present time there have been numerous volcanic outbursts at various places on the peninsula, and a portion of the material ejected from the volcanoes is possibly of Pliocene age. The Pleistocene or glacial epoch is represented by morainic deposits and some unconsolidated sands, clays, and gravels. Since the close of Pleistocene time there has been an accumulation of alluvial deposits in the valley bottoms, along the shores, and at the heads of the bays.

Sedimentation has not, however, gone on continuously throughout the peninsula from the beginning of the Mesozoic era to the close of the Miocene epoch, nor is it yet known to have gone on continuously during that time in any one portion of the peninsula. The sedimentary record is broken at many places by great unconformities which record periods when this land, or at least a part of it, stood above sea level and was subject to degradation, suffering from the activities of the agents of weathering and erosion just as does the land that rises above the sea level to-day.

The general succession of rocks in the province is shown in the following table: 
General section of rocks of the Alaska Peninsula.

\begin{tabular}{|c|c|c|c|c|c|c|}
\hline System. & Series. & Formation. & Geographic distribution. & Lithologic character. & $\begin{array}{l}\text { Thick- } \\
\text { ness. }\end{array}$ & Remarks. \\
\hline \multirow{2}{*}{ Quaternary. } & Recent. & & Stream valleys and beaches. & Sands, muds, and gravels. & Feet. & $\cdot$ \\
\hline & Pleistocene. & . & Lowlands and along valleys. & $\begin{array}{l}\text { Unconsolidated clays, sands, } \\
\text { gravels, and glacial drift. }\end{array}$ & & . \\
\hline \multirow{4}{*}{ Tertiary. } & Pliocene? & . & . & . & & . \\
\hline & Post-Miocene. & . & $\begin{array}{l}\text { Unga Island, Popof Island, Balboa } \\
\text { Bay, Port Moller, Chignik Bay, } \\
\text { Katmai Pass, and west end of pen- } \\
\text { insula. }\end{array}$ & $\begin{array}{l}\text { Tuffs, agglomerates, breccias, } \\
\text { and flows. }\end{array}$ & $1,000+$ & $\begin{array}{l}\text { At places volcanic deposits are accumu- } \\
\text { lating, and near the western end of } \\
\text { the peninsula mountains of volcanic } \\
\text { origin are not uncommon. }\end{array}$ \\
\hline & Miocene. & Unga formation. $a$ & $\begin{array}{l}\text { Unga and Popof islands, Balboa and } \\
\text { Herendeen bays, Port Moller, and } \\
\text { near head of Bristol Bay. }\end{array}$ & $\begin{array}{l}\text { Loosely cemented clays, sands, } \\
\text { gravels, and conglomerates. } \\
\text { Some beds furnish abundant } \\
\text { marine fossils. }\end{array}$ & $200+$ & $\begin{array}{l}\text { These deposits usually occur in very } \\
\text { small areas. }\end{array}$ \\
\hline & Oligocene? & . & . & $\because$ & & $\begin{array}{l}\text { Some of the fossil collections of inverte- } \\
\text { brates have been determined as pos- } \\
\text { sibly Oligocene in age, but the beds } \\
\text { from which they were obtained have } \\
\text { not been differentiated in mapping } \\
\text { from those of Eocene age. }\end{array}$ \\
\hline \multirow[t]{2}{*}{. } & Eocene. & Kenai formation. $a$ & $\begin{array}{l}\text { Unga Island, Center of Alaska Penin- } \\
\text { sula near Balboa Bay, Herendeen } \\
\text { Bay, Chignik Bay, near Katmai, } \\
\text { and at Cape Douglas. }\end{array}$ & $\begin{array}{l}\text { Shales, sandstones, grits, and } \\
\text { conglomerates. Locally car- } \\
\text { ries lignite. }\end{array}$ & 5,000 & $\begin{array}{l}\text { Carries workable lignite at Coal Har- } \\
\text { bor. Occupies a very large part } \\
\text { of the Alaska Peninsula between } \\
\text { Chignik and Pavlof bays. }\end{array}$ \\
\hline & Upper Cretaceous. & $\underset{\text { tion. }}{\text { Chignik form a - }}$ & $\begin{array}{l}\text { Chignik and Herendeen bays and near } \\
\text { Douglas Village. }\end{array}$ & $\begin{array}{l}\text { Conglomerate, sandstone, and } \\
\text { shales, with coal seams. }\end{array}$ & $600+$ & $\begin{array}{l}\text { Contains valuable coal beds at Chignik } \\
\text { and Herendeen bays. }\end{array}$ \\
\hline
\end{tabular}




\begin{tabular}{|c|c|c|c|c|c|c|}
\hline Cretaceous. & Lower Cretaceous. & $\begin{array}{c}\text { Herendeen lime- } \\
\text { stone.c }\end{array}$ & Herendeen Bay to Port Moller. & Arenaceous limestone. & 800 & \\
\hline · & & $\begin{array}{l}\text { S taniuk ovich } \\
\text { shale. } d\end{array}$ & $\begin{array}{l}\text { Herendeen Bay, Staniukovich Moun- } \\
\text { tain, and east to Port Moller. }\end{array}$ & $\begin{array}{l}\text { Shales and thin beds of sand- } \\
\text { stone. }\end{array}$ & $1,000+$ & \\
\hline \multirow{2}{*}{ Jurassic. } & Upper Jurassic. & $\underset{\text { tion.e }}{\text { Naknek formar }}$ & $\begin{array}{l}\text { Chignik and Herendeen bays, Naknek } \\
\text { Laks, Katmai, Cold Bay, Kamishak } \\
\text { Bay. }\end{array}$ & $\begin{array}{l}\text { Sandstone, conglomerate, and } \\
\text { arkose. }\end{array}$ & $1,000+$ & \\
\hline & Lower Jurassic. & & Cold Bay? & Shales and sandstones. & & $\begin{array}{l}\text { "At Cold Bay there are nearly } 4.000 \\
\text { feet of shales and sandstones lying } \\
\text { between the determined Triassic } \\
\text { rocks and the Cadoceras-bearing } \\
\text { Enochkin formation, but their exact } \\
\text { position in the Jurassic was not de- } \\
\text { termined by paleontologic evi- } \\
\text { dence."g }\end{array}$ \\
\hline Triassic. & Upper Triassic. & . & Cold Bay. & $\begin{array}{l}\text { Thin-bedded cherts, limestones, } \\
\text { and shales. }\end{array}$ & & \\
\hline
\end{tabular}

a Dall, W. H., Report on coal and lignite of Alaska: Seventeenth Ann. Rept. U. S: Geol. Survey, pt. 1, 1896, p. 836.

New formation name. The type section is exposed in Whalers Creek near Chignik Lagoon.

$d$ New formation name. The type section is exposed in Staniukovich Mountain east of Herendeen Bay. The formation is also well exposed in the north wall of Lawrence Valley.

e Spurr, J. E., A reconnaissance in southwestern Alaska in 1898: Twentieth Ann. Rept. U. S. Geol. Survey, pt. 7, 1900, p. 169.

$f$ Martin, G. C., The petroleum fields of the Pacific coast of Alaska: Bull. U. S. Geol. Survey No. 250, 1905, pp. 37-55.
$g$ Stanton, T. W., and Martin, G. C., The Mesozoic section on Cook Inlet and Alaska Peninsula: Bull. Geol. Soc. America. vol. 16, 1905, p. 397. 


\section{DISTRIBUTION OF FORMATIONS.}

The known distribution and the probable extensions of the geologic formations have been indicated on Plate VI (in pocket). In the northeastern part of the peninsula, crossed by Spurr in 1898 and visited along the eastern coast by Stanton, Martin, and Stone during the summer of 1904, the formations include one small area of Triassic rocks, on the eastern shore near Cold Bay, a belt of Middle Jurassic beds, extending from Cold Bay southward along the coast at least as far as Kialagvik Bay, a large area of Upper Jurassic rocks, extending through the central part of the peninsula and outcropping west of Cape Douglas, on the shores of Kamishak Bay, a belt of granite and syenite, bordering the Upper Jurassic belt on the northwest, and, still farther to the northwest and extending to the shores of Bristol Bay, a coastal plain area composed of Quaternary formations. Through the central portion of the peninsula, in the area occupied by the Jurassic formations, there is a belt of recent volcanic rocks. On the eastern coast, north of Katmai, large areas of Tertiary rocks have been located, and Cape Douglas is composed of Tertiary sediments overlain by andesitic lava. Near Douglas Village, on the east coast and a few miles south of Cape Douglas, there is an area of Cretaceous rocks, and the mountains west of Cape Douglas and bordering the coast are composed of granitic rock. At several points between Douglas Village and Katmai recent volcanic rocks are exposed.

Between this northeastern portion of the peninsula and the Chignik Bay region there is an area which has not yet been visited by members of the Geological Survey. The northwest portion, bordering Bristol Bay, is a continuation of the coastal plain area, recognized farther north, and this belt is presumably composed of Quaternary formations. The Middle Jurassic and the Upper Jurassic rocks that appear to the northeast and to the southwest probably form a considerable portion of this intervening unsurveyed area.

The distribution of the formations has been worked out in some detail in the Chignik Bay region. In the axis of the Aleutian Range, northwest of Chignik Bay, there is a belt of Upper Jurassic sediments. This belt is bordered on the north by the Quaternary formations of the northwest lowlands and on the south by a belt of Upper Cretaceous rocks. There are early Tertiary formations overlying the Upper Cretaceous in the area southwest of Chignik Bay. The entire series of sedimentary beds of this region appears to be cut off by a mass of volcanic rocks on the west and the headland northeast of Chignik Bay is composed of recent volcanics.

Between the Chignik Bay region and the area bordering Port Moller and Stepovak Bay the geologic conditions have not been studied in detail. The northern portion is composed of Quaternary formations. 
The Pacific Ocean side appears, seen from the vessel, to be made up of recent volcanic rocks, and to judge from the general features seen while coasting along the southern shore, the central portion is composed of a great sedimentary series, probably the eastward continuation of early Tertiary rocks of Chichagof Peak northwest of Stepovak Bay.

The area extending across the peninsula from Port Moller and Herendeen Bay on the north to the shores of Stepovak and Balboa bays, and still farther south to include Unga Island and a small portion of Popof Island, has been studied in some detail. The axis of the Aleutian Range in this portion of the peninsula is composed of early Tertiary formations. Bordering this belt on the north there is a small area in which Upper Jurassic, Lower Cretaceous, Upper Cretaceous, and some Recent volcanics are exposed. Still farther north is the coastal plain belt of Quaternary formations. South of the large area of Tertiary sediments, exposed in the axis of the range, there are irregular areas of Recent volcanic rocks, and at intervals along the coast there are small areas of Tertiary sediments. Within the axial belt of Tertiary, north of Balboa Bay, there are several Recent laccolithic intrusions and numerous dikes and sills.

West of the Balboa-Herendeen Bay district no systematic geologic work has been done. It appears from the general conditions and from such examination as has been made that the belt of Tertiary formations composing the axis of the range north of Balboa Bay continues west at least as far as Pavlof Bay. On the east shore of that bay characteristic early. Tertiary fossils were secured. Volcanic features are dominant west of Pavlof Bay. Several volcanoes are active, and so far as known the rest of the peninsula is composed of Recent volcanic rocks.

The islands south and southeast of the Alaska Peninsula, not already mentioned, are composed chiefly of Recent volcanic rocks, although more ancient and more coarsely crystalline igneous rocks are known to occur on some of them.

\section{STRUCTURE.}

The general geologic structure of the peninsula is anticlinal, but it is not that of a single anticline throughout the length of the peninsula, nor do the cross sections that have been worked out in detail show a simple anticlinal structure (figs. 1 and 2). The structure of the peninsula is more properly described as that of an anticlinorium.

Faulting has occurred at many places. In some faults the movement along a single plane was as much as 1,000 feet, and in others systems of distributive faults developed, with movements ranging from a few inches to several rods along the separate fault planes. Much of the lava that rose beneath the peninsula during the periods 
of volcanism failed to reach the surface. Some of this remained in vertical or nearly vertical fissures as dikes, other masses spread out between sedimentary strata as intrusive sheets or sills, and some entered the sedimentary series as great laccoliths and lifted the overlying beds in large domes.

The sedimentary formations rest in a nearly horizontal position in the northeast portion of the peninsula. As reported by Spurr, ${ }^{1}$ there is a slight upturning of the beds on either side of the belt of Recent volcanics through the central portion of this part of the peninsula.

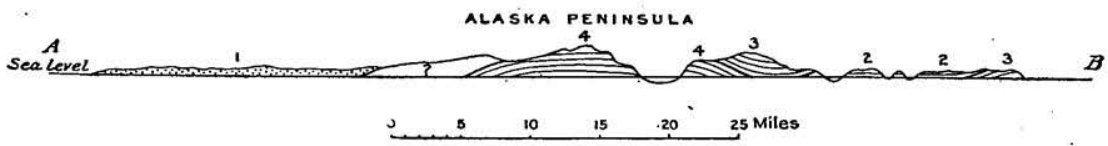

Frgure 1.-Structure section across the Alaska Peninsula along the line $A-B$, Plate VI (in pocket). 1, Quaternary; 2, Tertiary; 3, Cretaceous; 4, Upper Jurassic.

The coarse-grained crystalline rocks are beneath the Upper Jurassic and overlain by Quaternary formations to the northwest. Stanton and Martin ${ }^{2}$ report some open folding along the east coast, with the folds crosscut by an irregular series of faults. A structure section across the peninsula a few miles northeast of Cold Bay would include some Middle Jurassic and Upper Triassic near the Pacific Ocean.

In the Chignik Bay region, the general structure is that of a broad anticlinorium (fig. 1), and this structure continues westward through the Balboa-Herendeen Bay district (fig. 2), to the shores of Pavlof Bay. Bordering the main anticlinal fold in the axis of the range

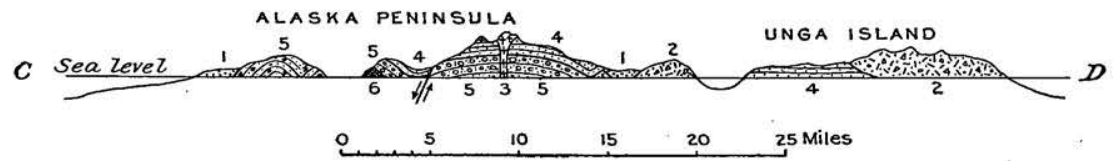

Figure 2.-Structure section across the Alaska Peninsula along the line $C-D$, Plate VI (in pocket).

1, Quaternary; 2, volcanic rocks; 3, dacite intrusions; 4, Tertiary; 5, Cretaceous; 6, Upper Jurassic.

are minor folds to the south in the Chignik Bay region and on both the north and south sides in the Balboa-Herendeen Bay region.

On the islands, so far as known, the massive igneous rocks are bordered and at some places covered by basic lava flows and bedded volcanic tuffs. The sedimentary rocks on these islands rest in a horizontal or nearly horizontal position in small areas near the coasts. More detailed descriptions of geologic structures accompanied by other structure sections will be found in other portions of this report.

\footnotetext{
1 Spurr, J. E., A reconnaissance in southwestern Alaska in 1898: Twentieth Ann. Rept. U. S. Geol. Survey, pt. 7, 1900, p. 146.

${ }^{2}$ Stanton, T. W., and Martin, G. C., The Mesozoic section on Cook Inlet and Alaska Peninsula: Bull. Geol. Soc. America, vol. 16, 1905, p. 393.
} 
STRATIGRAPHY.

Different portions of the peninsula have had geologic histories so different that the structural relations that may be worked out for any one region must necessarily be expected to differ from the structural relations in another part of the province. The geologic successions and stratigraphic relations in different portions of the peninsula are given in the following table:

Geologic succession and stratigraphic relations of rocks in different portions of the Alaska Peninsula.

\begin{tabular}{|c|c|c|c|}
\hline $\begin{array}{l}\text { Northeastern portion of the } \\
\text { peninsula. }\end{array}$ & Chignik Bay region. & $\begin{array}{l}\text { Balboa-Herendeen Bay } \\
\text { region. }\end{array}$ & Unga Island. \\
\hline $\begin{array}{l}\text { Glacial drift and recent } \\
\text { alluvium. }\end{array}$ & $\begin{array}{l}\text { Glacial drift and re- } \\
\text { cent alluvium. } \\
\text { Unconformity- }\end{array}$ & $\begin{array}{l}\text { Glacial drift and recent } \\
\text { alluvium. } \\
\end{array}$ & $\begin{array}{l}\text { Glacial drift and re- } \\
\text { cent alluvium. } \\
\text { Unconformity- }\end{array}$ \\
\hline \multirow[t]{4}{*}{ Recent volcanic rocks. } & $\begin{array}{l}\text { Recent volcanic rocks. } \\
\text { Unconformity }\end{array}$ & $\begin{array}{l}\text { Recent volcanic rocks. } \\
\text { Unconformity }\end{array}$ & $\begin{array}{l}\text { Recent volcanic rocks. } \\
- \text { Unconformity- }\end{array}$ \\
\hline & & $\begin{array}{l}\text { Pliocene? } \\
\text { Unconformity- }\end{array}$ & \multirow{3}{*}{$\begin{array}{l}\text { Miocene. } \\
\text { Oligocene? } \\
\text { Conformity- }\end{array}$} \\
\hline & & $\begin{array}{l}\text { Miocene. } \\
\text { Unconformity }\end{array}$ & \\
\hline & & $\begin{array}{l}\text { Oligocene? } \\
\end{array}$ & \\
\hline Eocene. Conformity?- & $\begin{array}{l}\text { Eocene. } \\
\text { Conformity }\end{array}$ & Eocene. & \multirow[t]{7}{*}{ Eocene. } \\
\hline $\begin{array}{l}\text { Upper Cretaceous. } \\
\text { Contact not seen }\end{array}$ & Upper Cretaceous. & $\begin{array}{l}\text { Upper Cretaceous. } \\
\text { Unconformity?- }\end{array}$ & \\
\hline & \multirow{5}{*}{ Upper Jurassic. } & $\begin{array}{l}\text { Lower Cretaceous. } \\
\text { Unconformity? }\end{array}$ & \\
\hline $\begin{array}{l}\text { Upper Jurassic. } \\
\text { Conformity }\end{array}$ & & \multirow[t]{4}{*}{ Upper.Jurassic. } & \\
\hline $\begin{array}{l}\text { Middle Jurassic. } \\
\text { Unconformity ? }\end{array}$ & & & \\
\hline (Lower Jurassic?) & & & \\
\hline $\begin{array}{l}\text { Upper Triassic } \\
\text { Base not seen. }\end{array}$ & & & \\
\hline
\end{tabular}

The base of the Upper Triassic series has not been seen, but it appears that an unconformity exists above the Upper Triassic and below the Middle Jurassic. The presence of the Lower Jurassic is not yet established. The relationship between the Middle Jurassic and Upper Jurassic is probably that of conformity. Between the Upper Jurassic and Lower Cretaceous the relationship has not been satisfactorily determined at any locality. There is probably a somewhat widespread unconformity between the Upper Cretaceous and Lower Cretaceous series, but sedimentation seems to have been continuous from late Cretaceous on into Eocene time, at least in the western part of the peninsula. If the Oligocene is represented at all, it is represented by the upper portion of the great conformable series of beds which includes the Upper Cretaceous and the Eocene. At most places the Mio cene rests unconformably upon older formations but on Unga Island it rests conformably upon the upper Eocene. An unconformity separates the rocks of Miocene age from all more recent deposits, and there is likewise an unconformable relationship 
between the recent sediments and the deposits of the Pleistocene epoch.

In short, the stratigraphic relations of the rocks of different periods is that of unconformity except where possible Oligocene rests upon Eocene, where Eocene sediments rest upon beds of Upper Cretaceous age, and possibly also in the relationship of the Middle and Upper Jurassic sediments, which may be conformable.

\section{CHARACTER AND DISTRIBUTION OF THE ROCKS.}

In this description of the rocks of the peninsula they are taken up in the order of their age, irrespective of sedimentary or igneous origin, beginning with the oldest and continuing to the most recent.

\section{ARGILLITE OF UNKNOWN AGE.}

A small patch of argillite is exposed on the east shore of Unga Island between Delarof and Baralof harbors, about $2 \frac{1}{2}$ miles northeast of the village of Unga. It is a dense, structureless rock, very brittle, as soft as slate, and without visible crystals. Under the microscope it appears to be of uniform composition, being made up of minute grains, and is of isotropic character. It is exposed in a bold sea cliff composed chiefly of volcanic tuffs that border and overlie it (see fig. 10, p. 70) and is possibly of pre-Tertiary age or older. The overlying tuffs are post-Miocene and probably recent. No similar formation was seen on the island.

\section{TRIASSIC SYSTEM.}

The oldest sedimentary rocks exposed in Alaska Peninsula are Upper Triassic. They outcrop near Cape Kekurnoi, at the north entrance of Cold Bay, and extend northeastward several miles. ${ }^{1}$ They doubtless underlie the Jurassic throughout the Cold Bay region. The Triassic rocks at this locality consist of thin-bedded chert, limestone, and shale of varied colors. The chert and limestone are usually black, green, or dark red when fresh, but weather to lighter shades. Stanton and Martin estimate the thickness of this series to be at least 2,000 feet, but state that in the exposures visited the base was cut off by intruded igneous rocks. The Triassic rocks are reported to be closely folded, frequently crumpled, and cut by numerous dikes, some of granite, others of andesite and basalt. The igneous rocks were intruded soon after the folding, which must have closely followed Triassic time, for they do not cut younger rocks. The Triassic fauna of the region, as now known, is almost limited to a single species, Pseudomonotis subcircularis Gabb, which, however, is very abundant

${ }^{1}$ Stanton, T. W, and Martin, G. C., The Mesozoic section on Cook Inlet and Alaska Peninsula: Bull. Geol. Soc. America, vol. 16, 1905, p. 393. 
in certain layers of shale and limestone at Cold Bay. Of this species Stanton and Martin state:

In California Pseudomonotis subcircularis is confined to the Swearinger slates, which form the uppermost Triassic formation in that region. Similar beds with the same fossil occur in Vancouver and Queen Charlotte Islands and on the mainland of British Columbia, and they cover considerable areas in the Copper River region of Alaska. ${ }^{1}$

A few imperfect ammonites have also been found in the exposures bordering ('old Bay from beds overlying the Pseudomonotis layer. These ammonites, when generically determined, may possibly indicate a still higher horizon of Triassic.

JURASSIC SYSTEM.

LOWER JURASSIC ROCKS.

No rocks in the Alaska Peninsula have yielded Lower Jurassic fossils, but at Cold Bay there are nearly 4,000 feet of shales and sandstones, as reported by Stanton and Martin, ${ }^{2}$ between the known Triassic horizon and the Middle Jurassic. The exact position of these rocks has not been determined by paleontologic evidence. In the vicinity of Cold Bay the unconformity between the Triassic and Jurassic, known to exist farther north on the shores of Cook Inlet, is not obvious, and the boundary between the two systems has not yet been definitely fixed. The structural relations are obscured at several points by faults.

GRANITES AND SYENITES, PROBABLY OF LOWER OR MIDDLE JURASSIC AGE.

One area in the northwestern portion of the peninsula (Pl. VI, in pocket), at the west end of Becharof and Naknek Lakes, is composed of igneous rocks, which are of pre-Upper Jurassic age or older. This belt was crossed by Spurr in 1898, and reported ${ }^{3}$ by him to be composed of coarse-grained granitic rocks, and to occupy a considerable area on the northwest side and parallel with the main trend of the peninsula. Some syenite and an extensive outcrop of hornblende granite-aplite were also found by Spurr in the area bordering the lower end of Naknek Lake.

The sedimentary rocks adjoining this area and extending southeastward are of late Jurassic age, and contain an abundance of arkose and some conglomerates. The resemblance of the granite pebbles in the conglomerates and of the granitic material in the arkoses suggest that the material for these sedimentary formations may have been derived from the neighboring crystalline rocks, and that the latter

${ }_{1}$ Stanton, T. W., and Martin, G. C., op. cit., p. 396.

2 Idem, p. 397.

${ }^{3}$ Spurr, J. E., A reconnaissance in southwestern Alaska: Twentieth Ann. Rept. U. S. Geol. Survey, pt. 7,1898 , p. 232. 
are, therefore, at least of pre-Upper Jurassic age. Mount Douglas and the neighboring peaks have been reported by $R$. W. Stone to be composed of coarsely crystalline rocks.

No other igneous rocks on the peninsula have been found in such relations as to suggest for them an age preceding that of the Upper Jurassic rocks. In the Herendeen Bay district the Upper Jurassic sediments are composed of conglomerates and arkoses, which suggest the proximity of an exposure of granitic rocks to that region during late Jurassic time.

The age of these rocks has therefore not been definitely determined, but G. C. Martin has informed the writer that similar large areas of granitic rocks of early Jurassic or mid-Jurassic age exist a little farther north and are probably the continuation of the area reported by Spurr in 1898.

MIDDLE JURASSIC ROCKS ("ENOCHKIN FORMATION").

Character and distribution.-The Middle Jurassic is well exposed on the east shore of Enochkin Bay, a small reentrant on the west side of Cook Inlet about 40 miles north of the northeast terminus of the Alaska Peninsula as-herein defined. These rocks cover a large area in the vicinity of Cold Bay (PI. VI, in pocket), and the occurrence of Cadoceras wossenessenskii, near Katmai, reported by Grewingk, indicates another possible locality for their occurrence on the peninsula. Stanton and Martin ${ }^{1}$ measured 1,650 feet of Middle Jurassic sandstones, shales, and conglomerates on the shores of Enochkin Bay, and these observers estimated that at least half the total thickness was concealed.

Because of the development of the Middle Jurassic rocks in the Enochkin Bay region the name "Enochkin formation" was applied to the beds. Of the exposures of these rocks in the Cold Bay region Martin ${ }^{2}$ has said:

The Enochkin formation occupies both shores of Cold Bay except at the northeastern promontory (Cape Kekurnoi) and at the head of the bay. It also extends in a belt along the shore of Shelikof Strait from Cold Bay to Dry Bay and probably as far beyond as Portage Bay.

On the same page he gives the following measured section, which is exposed on the east side of Rex Creek, about 1 mile above the head of Dry Bay:

\footnotetext{
1 Stanton, T. W., and Martin, G. C., op. cit., p. 398.

2 Martin, G. C., Petroleum fields of the Pacific coast of Alaska: Bull. U. S. Geol. Survey, No. 250, 1905, p. 53.
} 
Mesozoic section on Rex Creek, Cold Bay region.

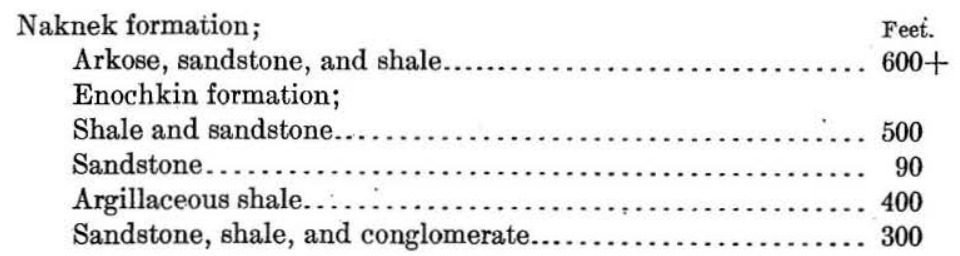

Fauna and flora.-The paleontologic evidence from the Cold Bay exposures of the "Enochkin formation" has been presented as follows: ${ }^{1}$

This portion, which we have mentioned as "zone D," or the "Cadoceras zone," has been recognized by its fossils from Snug Harbor to Cold Bay. Its characteristic ammonites have been assigned to the Callovian by Neumyr, Hyatt, and Pompeckj, all of whom recognized the character of the fauna, which is represented by closely similar forms in Russia, Franz Josef Land, and elsewhere in northern regions, as well as in other parts of Europe. This Callovian fauna is placed by many geologists in the lower part of the Upper Jurassic, but it seems to accord better with the local development in Alaska to follow the custom of some German geologists and assign it to the top of the Middle Jurassic. Seven species of Cadoceras have been named from Alaska, some of which will evidently become synonyms when the large collections now on hand are fully studied, and possibly one or two additional names will be necessary. With these are associated Spæroceras, Phylloceras, and one or two other genera of ammonites, belemnites, and a very few pelecypods and gastropods.

A few plants, referred by Dr. F. H. Knowlton ${ }^{2}$ to Cladophlebis denticulata, Ctenis grandifolia, Hausmannia sp., and Dictyophyllum cf. D. obtusilobum, have been found with the marine invertebrates.

UPPER JURAGSIC ROOKR.

NAKNEK FORMATION.

Name and original description.-The Naknek formation was first described by Spurr ${ }^{3}$ from the vicinity of Naknek Lake and Katmai. He says of it:

The Naknek series consists of a great thickness of granitic arkose and of conglomerate which generally contain pebbles of granite. All of these sedimentary rocks are evidently derived from the destruction of a land mass which consisted largely of hornblende-biotite granite. There are probably some volcanic flows interstratified with the arkose and conglomerates, although it is not absolutely proved that those examined may not be intrusive. The series is cut by andesite-basaltic (aleutitic) lava of later age, especially along the axis of the range, where the amount of volcanic rock is very great.

Throughout the whole series the arkoses carry abundant fossil remains, both of plants and of marine organisms.

1 Stanton, T. W., and Martin, G. C., The Mesozoic section on Cook Inlet and Alaska Peninsula: Bull. Geol. Soc. America, vol. 16, 1905, p. 401.

2 Op. cit.

${ }^{3}$ Spurr, J. E., A reconnaissance in southwestern Alaska: Twentieth Ann. Rept. U. S. Geol. Survey, pt. 7, 1898, pp. 169-171.

$90054^{\circ}-$ Bull, $467-11-3$ 
Elsewhere Spurr alludes to the presence of beds of gray compact limestone in the formation, and on page 180 he adds:

Throughout the whole series are abundant plant remains, which, so far as examined, were not determinate, and marine faunal remains that indicate a probable Upper Jurassic age.

He estimated the thickness exposed in the mountains near Katmai as at least 1,500 feet. The section exposed on the cliffs on the east side of Katmai Bay was described as consisting of hard and massive dark-gray arkose at the bottom, overlain by a probable flow of massive andesite, above which are other beds of arkose and conglomerate. The gray compect limestone with Jurassic fossils is found at various points in the rocks.

Craracter and distribution.-At the extreme northeastern margin of the peninsula, on the shores of Kamishak Bay, the Naknek formation is well exposed. Here the formation consists largely of sandstones which are very fossiliferous.

The Naknek formation probably occupies a large portion of the peninsula in the vicinity of Katmai and Naknek Lake (Pl. VI) and extends southward beyond Cold Bay and Becharof Lake. Martin has made the following report regarding it: ${ }^{1}$

The Naknek formation forms the shore of the head of Cold Bay and occupies the entire interior region as far west as Becharof Lake and as far north as Katmai.

On the same page he states that a section in the Naknek formation exposed in Rex Creek about 1 mile above the head of Dry Bay, the first bay south of Cold Bay, includes somewhat more than 600 feet of arkose, sandstone, and shale.

The distribution of this formation in the Chignik Bay and Herendeen Bay districts is indicated on Plates VII and VIII. Th€ Naknek formation is exposed in the axis of the Aleutian Range in the Chignik Bay region. The detailed mapping was not completed in this region, but the formation probably occupies a considerable beit through the central portion of the peninsula. It consists here of a series of sandstones, shales, and conglomerates. The sandstones of the Naknek formation exposed on the shores of Chignik Lagoon and on the shores of Chignik Lake are fine-grained and firmly cemented rocks of dark-gray colors. These exposures yielded collections of fossil invertebrates, which will be referred to later as collections No. 58a and No. 56, respectively. Northwest from the head of Hook Bay the Upper Jurassic is represented by thin-bedded sandstones, which yielded fossil collection No. 50, and by some grits, conglomerates, and shales.

In the Herendeen Bay region the Upper Jurassic outcrops are limited to a few projecting points near the head of the bay, and to

\footnotetext{
${ }^{1}$ Martin, G. C., Petroleum fields of the Pacific coast of Alaska: Bull. U. S. Geol. Survey Nc. 250, 1905, p. 53.
} 
one locality in the small peninsula between Herendeen Bay and Port Moller. In this region the formation is north of the main anticlinal axis of the Aleutian Range and in the central portions of minor double-plunging anticlines that have been deeply dissected, first by running water and later by ice erosion. In this region the Naknek formation is limited to areas lying within 1,000 feet of sea level and is composed of sandstones, shales, conglomerates, grits, and arkose. The sandstones and arkoses appear to have come from rocks of a granitic nature, and the conglomerates contain an abundance of quartz pebbles that may have come from granitic rocks.

The sections measured near the base and on the east side of Pinnacle Mountain, near the head of Herendeen Bay, is given below:

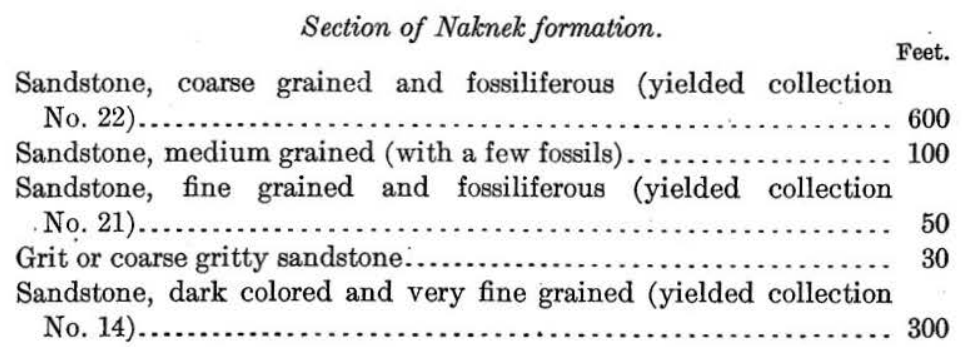

Fauna.-Stanton has made the following report on the paleontologic material referred to above and on other collections obtained from the Naknek formation in the Herendeen Bay and Chignik Bay regions during the season of 1908 :

Collections of fauna of the Naknek formation.

No. 14. East base of Pinnacle Mountain, Herendeen Bay:

Pecten sp. a.

Pecten sp. b.

Pecten? sp. c.

Aucella sp. related to $A$. bronni Rouillier.

Arca sp.

No. 15. Bold Bluff Point, Herendeen Bay:

Aucella sp. related to $A$. bronni Rouillier.

No. 21. Canyon on east face of Pinnacle Mountain, Herendeen Bay:

Aucella sp. related to $A$. bronni Rouillier.

No. 22. Canyon on east face of Pinnacle Mountain, above horizon that yielded collection No. 21:

Terebratula sp.

Pecten sp. Large, smooth form.

Avicula sp.

Aucella sp. related to $A$. pallasi Keyserling.

Cyprina sp.

Pleuromya sp.

No. 24. Crow Póint, Herendeen Bay:

Eumicrotis sp.

Aucella sp. related to $A$. pallasi Keyserling. 
No. 24. Crow point, IIerendeen Bay-Continued.

Cyprina sp.

Pleuromya sp.

Belemnites sp.

No. 25. Crow Point, Herendeen Bay:

Aucella sp. related to A. pallusi Keyserling.

No. 26. Crow Point, Herendeen Bay:

Pecten sp. Large, smooth form.

Eumicrotis sp.

Aucella sp. related to A. pallasi Keyserling.

Cyprina sp.

Pleuromya sp.

No. 27. Crow Point, Herendeen Bay:

Same species as in 26 with Tancredia and Belemnites additional.

No. 50. North side of Chignik Bay, on mountain top north of Bear Creek.

Lima sp. related to $A$. bronni Rouillier.

Turbo sp.

Belemnites sp.

IIorizon, Upper Jurassic.

No. 56. Chignik Lake, in fine-grained dark-colored sandstone exposed along the shore in the southwest arm of the lake:

Aucella sp. related to $A$. bronni Rouillier.

Horizon, Upper Jurassic.

No. 58a. Chignik Lagoon, about opposite Alaska Packers' Association's cannery:

Lima sp.

Aucella sp. related to $A$. bronni Rouillier.

Phylloceras? sp. Fragmentary imprint.

Horizon, Upper Jurassic.

No. 59. IIook Bay Creek, near coal mine:

Aucella sp. related to $A$. pallasi Keyserling.

IIorizon, Upper Jurassic.

Stanton has discussed the faunal relations of the Naknek formation as follows: ${ }^{1}$

The fauna of the Naknek formation is especially characterized by the presence of Aucella belonging to species very closely related if not identical with $A$. pallasi and A. bronni of the Russian Volga beds. These fossils are at some localities very abundant, completely filling thick beds. At other places they are so rare that they may be easily overlooked, but a careful search will find them in almost every section. Associated with the Aucella there are usually two or three species of Belemnites, frequently a large Lytoceras and a Phylloceras, and occasionally a few gastropods, Trigonia, and other pelecygods. It is clear that the Naknek formation is of about the same age as the Mariposa beds of California with Aucella erringtoni and Cardioceras ef. alternans, ${ }^{2}$ and it also includes the horizon of the marine Jurassic with Cardiocerus cordiforme in the Black Hills, where, however, the Aucella element is lacking from the fauna, and probably only the horizon of the basal portion of the Naknek is represented. A similar fauna occurs in Russia in the Volgian beds, and it is widespread in the boreal region, occurring on Spitzbergen, Nova Zembla, and elsewhere.

Structure and stratigraphic relations.-At the northeastern extremity of the peninsula, and a little west of Cape Douglas, the Naknek sedi-

\footnotetext{
${ }^{1}$ Stanton, T. W., and Martin, G. C., The Mesozoic section of Cook Inlet and Alaska Peninsula: Bull. Geol. Soc. America, vol. 16, 1905, p. 407.

${ }^{2}$ Two names, $C$. whitneyi Smith and C. dubium Hyatt, have been proposed for probably the same species in this formation.
} 
ments rest in a nearly horizontal position, but their relations to other formations in that part are not as yet known. In the central portion of the peninsula, between Katmai and Naknek Lake, the Naknek strata are gently folded. They are reported by Spurr to be upturned on either side of the belt of volcanic rocks which occupy the axis of the Aleutian Range in this portion of the peninsula.

A little farther south in the Cold Bay-Becharof Lake region there is a series of anticlines and synclines with nearly parallel axes trending in a general northeast-southwest direction.

The section there exposed is given in the following table:

General section in the Cold Bay-Becharof Lake region. ${ }^{a}$

\begin{tabular}{|c|c|c|c|}
\hline Formation. & $\Lambda$ ge. & Lithologic character. & Thickness. \\
\hline $\begin{array}{l}\text { Naknek formation. } \\
\text { "Enochkin" formation. }\end{array}$ & $\begin{array}{l}\text { Post-Jurassic. } \\
\text { Late Jurassic. } \\
\text { Mid-Jurassic. } \\
\text { Triassic. } \\
\text { Pre-Jurassic. }\end{array}$ & $\begin{array}{l}\text { Volcanic rock, probably andesite } \\
\text { or basalt. } \\
\text { Arkose, conglomerate, sandstone, } \\
\text { and shale. } \\
\text { Shale, sandstone, and a little lime- } \\
\text { stone. } \\
\text { Shale. limestone, and chert. } \\
\text { Granite, syenite, etc. }\end{array}$ & $\begin{array}{c}\text { Feet. } \\
3,000-5,000 \\
2,000\end{array}$ \\
\hline
\end{tabular}

$a$ Martin, G. C., Petroleum fields of the Pacifie coast of Alaska: Bull. U. S. Geol. Survey No. 250, 1905, p. 52 .

The main anticlinal axis in this region extends from Kanata, at the head of Portage Bay northeastward between Becharof Lake and Cold Bay (Pl. VI, in pocket). There is a syncline parallel to this main fold extending from the region about the mouth of Oil Creek northeastward nearly to the shores of Cold Bay, where it is cut off by a fault. The exposure of Triassic rocks and the northwestward dip of the strata farther northeast on the north side of Cold Bay seem to indicate another anticlinal axis which may pass through the headlands along the coast.

A synclinal trough passes northwest of the main anticlinal fold in a northeast-southwest direction through Becharof Lake, and still farther west at the lower end of the lake is another upturning of the sedimentary formations and an exposure of coarsely crystalline rocks. The dips are low over wide areas and the zones of steep dip are narrow and infrequent. Observed dips near Cold Bay vary, none exceeding $16^{\circ}$.

In the Chignik Bay region (Pl. VII) the base of the Naknek formation was not seen, but an erosion plane separates this formation from the overlying Upper Cretaceous sediments. This unconformity is perhaps best shown on the northwest coast of Chignik Bay near the entrance to Chignik Lagoon and on the northwest shore of that lagoon. At these localities the structural break is distinct and fossil material is available from both horizons. In the exposure west of Hook Bay the Naknek strata stand at angles as high as $50^{\circ}$, and 
when the structural relations in this portion of the field are worked out in detail they will probably demonstrate a great structural break between the Upper Jurassic and the Upper Cretaceous. In the exposures about the shores of Chignik Lake the Naknek beds appear in broad open folds, the departure from horizontality usually being less than $10^{\circ}$.

The main anticlinal axis in this region has a northeast-southwest direction passing through Chignik Lake (Pl. VII) and following the crest line of the Aleutian Range in either direction (fig. 1, p. 28). The axis is about 8 miles west from the head of Hook Bay and apparently continues northeast in the direction of Portage Bay, where it may become continuous with the axis extending northward from the head of that bay and between Becharof Lake and Cold Bay. The northwest side of this fold was not seen to advantage in the Chignik Bay region, but on the southeast there are a number of gentle folds shown in the bold headlands on the south side of the bay from Chignik Lagoon to Castle Cape (Pl. V, $A$, p. 38) at the southern entrance to Chignik Bay.

In the Herendeen Bay region (PI. VIII) the Naknek formation is exposed in the central portions of dissected anticlines; and the beds rest at angles not exceeding $20^{\circ}$. In this region, especially in the Crow Point exposures, the formation is much faulted, and the base is not exposed. One of the contacts with the Lower Cretaceous is by faulting; the other is obscured by talus accumulations and vegetation. The stratigraphic relations between the Upper Jurassic and Lower Cretaceous in this region are therefore not yet known. The general structural conditions in this portion of the peninsula are given in figure 2 (p. 28). More detailed sections are given in figures 5 (p. 59) and 13 (p. 97).

CRETACEOUS SYSTEM.

LOWER CRETACEOUS ROCKS.

Two distinct Lower Cretaceous formations are exposed in the Herendeen Bay reigon, but have not yet been recognized elsewhere in the peninsula. They outcrop on the east shore of Herendeen Bay and extend northeastward through the coal field to the vicinity of Hot Springs on the shores of Port Moller. (See Pl. VIII.)

STANIUKOVICH SHALE.

A series of shales that constitute a large part of Staniukovich Mountain, a peak 2,400 feet high, overlooking the entrance to Port Moller, has been called the Staniukovich shale. The mountain was named for Capt. Mikhail Nikolaievich Staniukovich, who was in 
U. S. GEOLOGICAL SURVEY

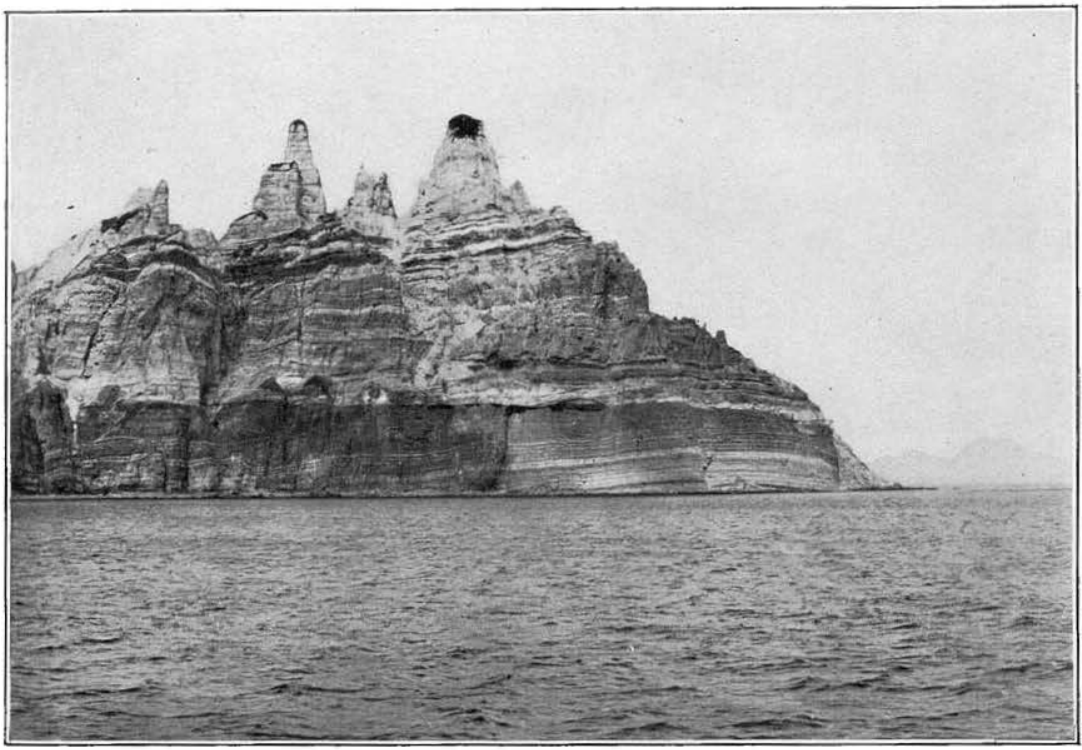

A. TULIUMIT POINT, LOCALLY KNOWN AS CASTLE CAPE, AT SOUTH ENTRANCE TO CHIGNIK BAY. See pages 38,92 .

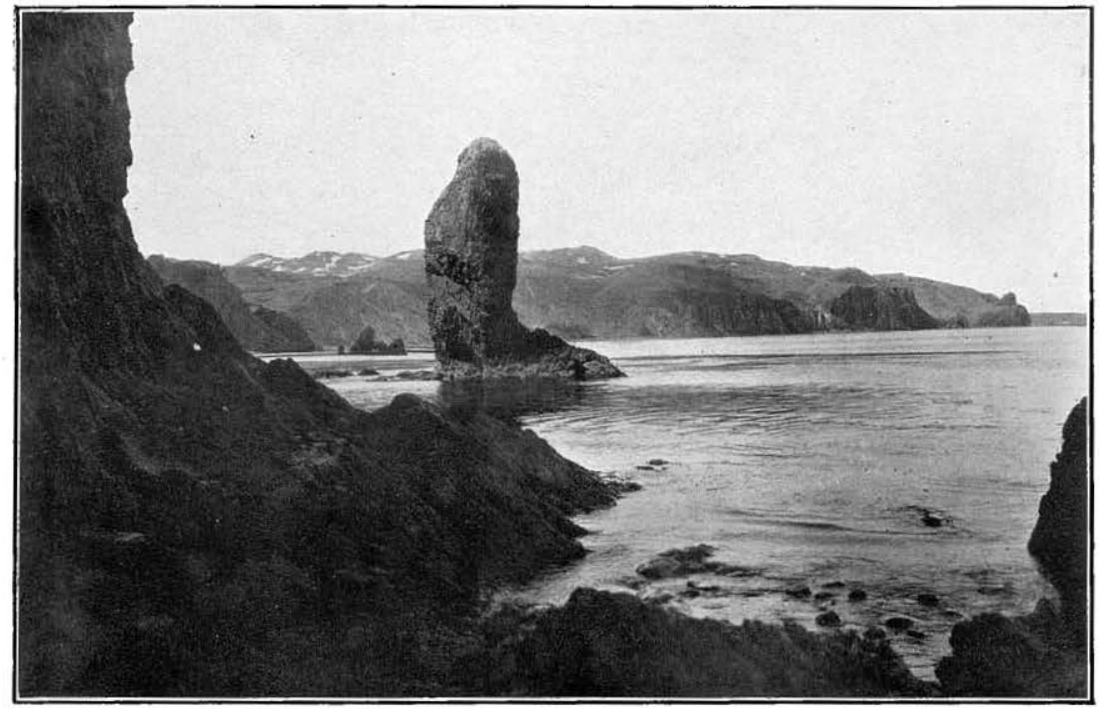

B. EAST COAST OF UNGA ISLAND NORTH OF UNGA HARBOR.

The composition and structural relations of this cliff are shown diagrammatically in figure 10. See page 70 . 

command of the sloop Moller on a surveying expedition to this part of Alaska in the year 1828.

The Staniukovich shale, which makes up the lower portion of the Lower Cretaceous of this region, includes at least 1,000 feet of shales with thin beds of sandstone. This formation underlies conformably the Herendeen limestone and is lithologically very different from the sediments composing the Naknek formation, of late Jurassic age. The Staniukovich shale is we exposed in Staniukovich Mountain and in the north wall of Lawrence Valley. The shales are thin bedded, and talus material forms upon them so rapidly that they weather down to softened slopes of dull reddish colors without striking physical characters.

HERENDEEN LIMESTONE.

The upper portion of the Lower Cretaceous of this region is an arenaceous limestone of light-gray color, locally cross-bedded and tossiliferous. The formation is 800 feet thick, and owing to its superior resistance to the agents of weathering it has come to form conspicuous ridges in the coal field.

.The Herendeen rock is a yellowish, sand-colored fine-grained limestone, with numerous minute plates of black mica on the sedimentation planes. Locally it contains abunäint fragments of shells and, at places where the shell forms are lost the comminuted shell material may be recognized. The shells that have yielded most of such material were pectens. A microscopic examination ${ }^{1}$ of this rock shows that it is "mainly composed of dirty carbonate occurring in small short rectangular forms, but longer pieces are found, and these show curvature indicating a detrital organic origin. Throughout the section are scattered subangular fragments of quartz and plagioclase and sporadic flakes of biotite; as accessories there occur fragments of pyroxene, of rounded microlitic andesite, and grains of magnetite."

The Herendeen limestone, though folded and somewhat faulted, may be traced east from Coal Harbor for several miles; thence northwest until it outcrops on the shore of Herendeen Bay a little north of Coal Harbor. These outcrops are on the sides of a plunging syncline. Farther north the same arenaceous limestone outcrops again on the flanks of a neighboring anticline and extends east below recent volcanic tuffs and flows until it outcrops on the west shore of Port Moller.

FAUNA.

Several collections of invertebrate forms have been secured from. these Lower Cretaceous formations, and from an examination of this material Dr. Stanton has recognized two horizons. The higher

\footnotetext{
1 The description of the microscopic characters of the rocks given in this report is by Adolph Knopf.
} 
horizon contains forms related to Aucella crassicollis and the lower forms related to Aucella piochii. The localities at which these col-lections were made are given below in Dr. Stanton's report:

Collection of Lower Cretaceous fauna.

No. 13. West side of the basin of Coal Valley and about 500 feet above sea level. Aucella sp. related to A. piochii Gabb.

Aucella sp. related to A. crassicollis Keyserling.

No. 16. Just south of Shingle Point east side of Herendeen Bay. Aucella sp. related to A. crassicollis Keyserling.

No. 17. Between Shingle Point and Marble Point, east side of Herendeen Bay. Aucella sp. related to A. piochii Gabb.

No. 28. From high ridge south of Johnson tunnel in Mine Creek. Aucella sp. related to A. crassicollis Keyserling.

No. 29. From 1,100 foothills about 3 miles northeast of Mine Harbor. Same Aucella as in 28.

No. 33. Sandstone near Hot Springs, Port Moller. Aucella sp. related to A. crassicollis Keyserling. Pecten sp., large, smooth form.

No. 34. From shales exposed one-half mile north of Hot Springs, Port Moller. Inoceramus sp.

Pleuromya sp.

Belemnites sp.

Desmoceras? sp.

All of the collections that contain forms related to Aucella crassicollis Keyserling, except collection No. 13, are known to have come from the Herendeen limestone. Collection No. 17, with forms related to Aucella piochii, came from the Staniukovich shale. Collection No. 13, which contains both the above types, was secured from what was believed to be the Herendeen limestone, but the formation could not be absolutely identified because much of the region was covered by a heavy mantle of snow.

STRATIGRAPHIC RELATIONS.

As has already been stated, the Herendeen limestone and Staniukovich shale are sections of a conformable series. The base of the Staniukovich has not as yet been- seen in contact with any other formation, so the structural relations at that horizon are not known. In Crow Point near the mouth of Lawrence Valley there are good exposures of Upper Jurassic rocks, but this area is structurally separated from the north wall of Lawrence Valley, where the Lower Cretaceous formations outcrop, by a fault. In Coal Valley the base of the Lower Cretaceous is obscured by loose material and vegetation. The paleontologic material collected from the section exposed on the east side of Pinnacle Mountain includes an abundance of Upper Jurassic forms from the lower 400 feet and some Upper Cretaceous material at 900 feet above the sea. The intervening strata from 400 to 900 feet have been mapped as Upper Cretaceous, but the possi- 



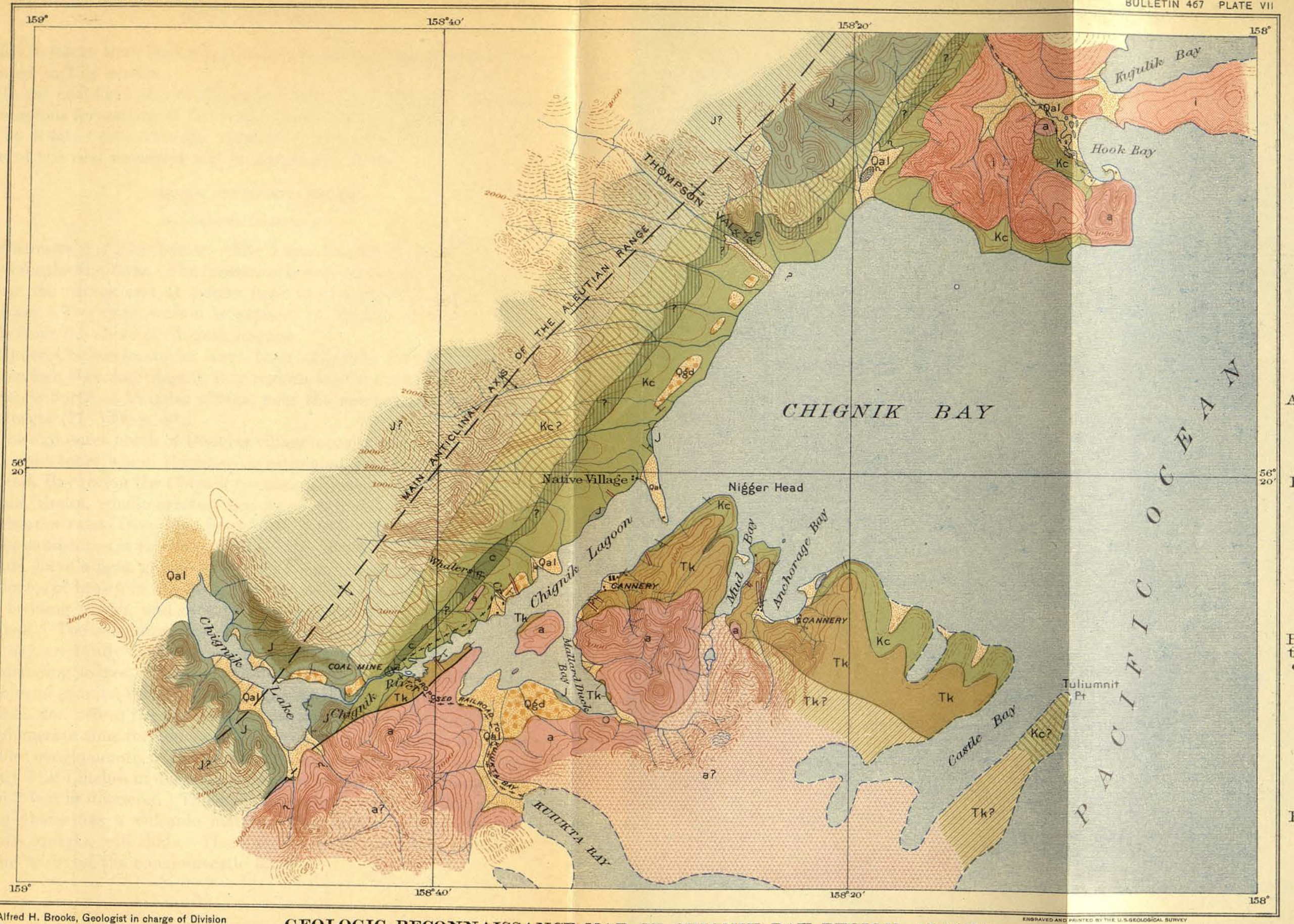

Pumice

Recent volcamics

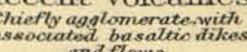

Probable extensio
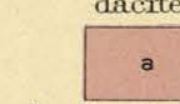

Andesites and dacites tuffs and breccias

The?

Probable extension of the Kenai formation Tk

Kenai formation Sandstones, shates and
conglomerates, withsome
lignite

$$
\text { ko? }
$$

robable extension of coal-bearing series

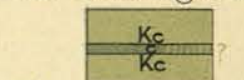

Chignik formation

Sandstones, shates, and
conglomberates, withsome
valuable coal seams

1?

robable extemsion of knek formation J

Naknek formatio Sandstone, shales, and
conglomerates, marine

$$
\begin{gathered}
\text { Contour interval } 200 \text { feet. } \\
\text { Datum is mean sea level. }
\end{gathered}
$$



bility remains that Lower Cretaceous formations are in part represented in this section.

In the coal field east of Herendeen Bay the relation of the Lower Cretaceous formations to the coal measures, which have been judged to be of late Cretaceous age, appears to be that of conformity. The age of the coal measures will be considered later.

\section{UPPER CRETACEOUS ROCKS.}

CHIGNIK FORMATION.

Character and distribution.-The name Chignik formation is here used for the first time. The formation is well exposed at several places along the shores and at points near to Chignik Bay and Chignik Lagoon. The type section is exposed in Whalers Creek, one-half : mile from the shore of Chignik Lagoon.

Upper Cretaceous rocks have been definitely recognized in the Herendeen Bay and Chignik Bay regions and in a small area a short distance north of Douglas village, near the northeastern end of the peninsula (Pl. VII, p. 40).

The exposures north of Douglas village consist of a series of shales and sandstones whose thickness is estimated at 2,000 feet. In the Chignik Bay region the Chignik formation consists of a series of sandstones, shales, conglomerates, and some valuable coal seams. The sandstones range from fine, even-grained sediments to grits. Many of the sandstones in this formation, as exposed in Nigger and Chignik Heads, have a light green color when fresh, but weather to black or to shades of brown in the cliffs. Ripple marks are not uncommon on the bedding planes, and in some of the strata there are large concretions. The conglomerates are conspicuous members in the series, for they are firmly cemented and form cliffs or even, in some places, overhanging ledges. These conglomerates in Chignik Head contain pebbles of granite, quartz, greenstones, and flint as large as 2 inches in diameter. Near the entrance to Chignik Lagoon there is a coarse conglomerate that for convenience in the field was spoken of as the cobble conglomerate. The stones in this conglomerate are commonly 3 or 4 inches in diameter, but some of the bowlders found in it were 2 feet in diameter. This conglomerate is poorly bedded and in some places has a volcanic matrix. The stones include granites, basalts, quartz, and shale. There are lenses of sandstone and shale in the midst of the conglomeratic layer. 
The section as exposed along the shore of Chignik Lagoon and out to Nigger Head is given below.

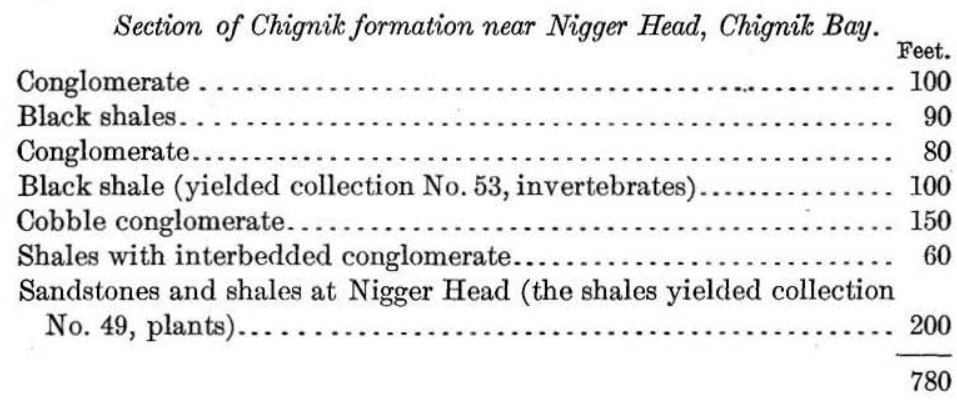

Many other good exposures of the Upper Cretaceous rocks occur along the northwest shores of Chignik Bay and Chignik Lagoon, and . in the mountain valleys to the northwest. In Thompson Valley, along Whalers Creek, and along the banks of Chignik River near the coal mine the formation is equally well shown. In the exposures northwest of Chignik Bay and Chignik Lagoon the series is coal bearing, and the exposures in this portion of the field will therefore receive special attention later in the report. The distribution and probable extension of the Chignik formation in this region are shown on Plate VII (p. 40).

The Upper Cretaceous rocks are exposed at several places in the Herendeen Bay district. (See Pl. VIII, p. 42.) There is one small area in the central part of the peninsula, midway between Balboa and Herendeen Bays and on the north si e of a large laccolithic intrusion. The larger exposures are in the vicinity of Herendeen Bay, where the upturned. Chignik strata appear on the flanks of anticlinal and synclinal folds. West of the west arm of Herendeen Bay the Upper Cretaceous sediments are near the base of the mountains. The basal portion of Pinnacle Mountain is composed in part of the Chignik formation, as is also a portion of the south wall of Lawrence Valley. Coal has been reported along the tributaries of Lawrence Valley from the south, and it is quite possible that productive seams may be located there. - In the coal field as now defined the Chignik formation outcrops in a westward plunging syncline east of coal Harbor, at Coal Bluff on the east shore of Herendeen Bay, and over a large area east of the head of Coal Valley. The formation consists of a series of sandstones, shales, conglomerates, and coal. The section exposed in Mine Creek and about $1 \frac{1}{2}$ miles east of Coal Harbor includes:

Section of Chignik formation in Mine Creek.

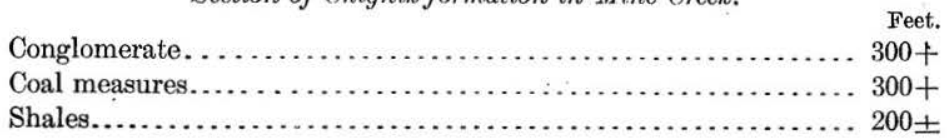





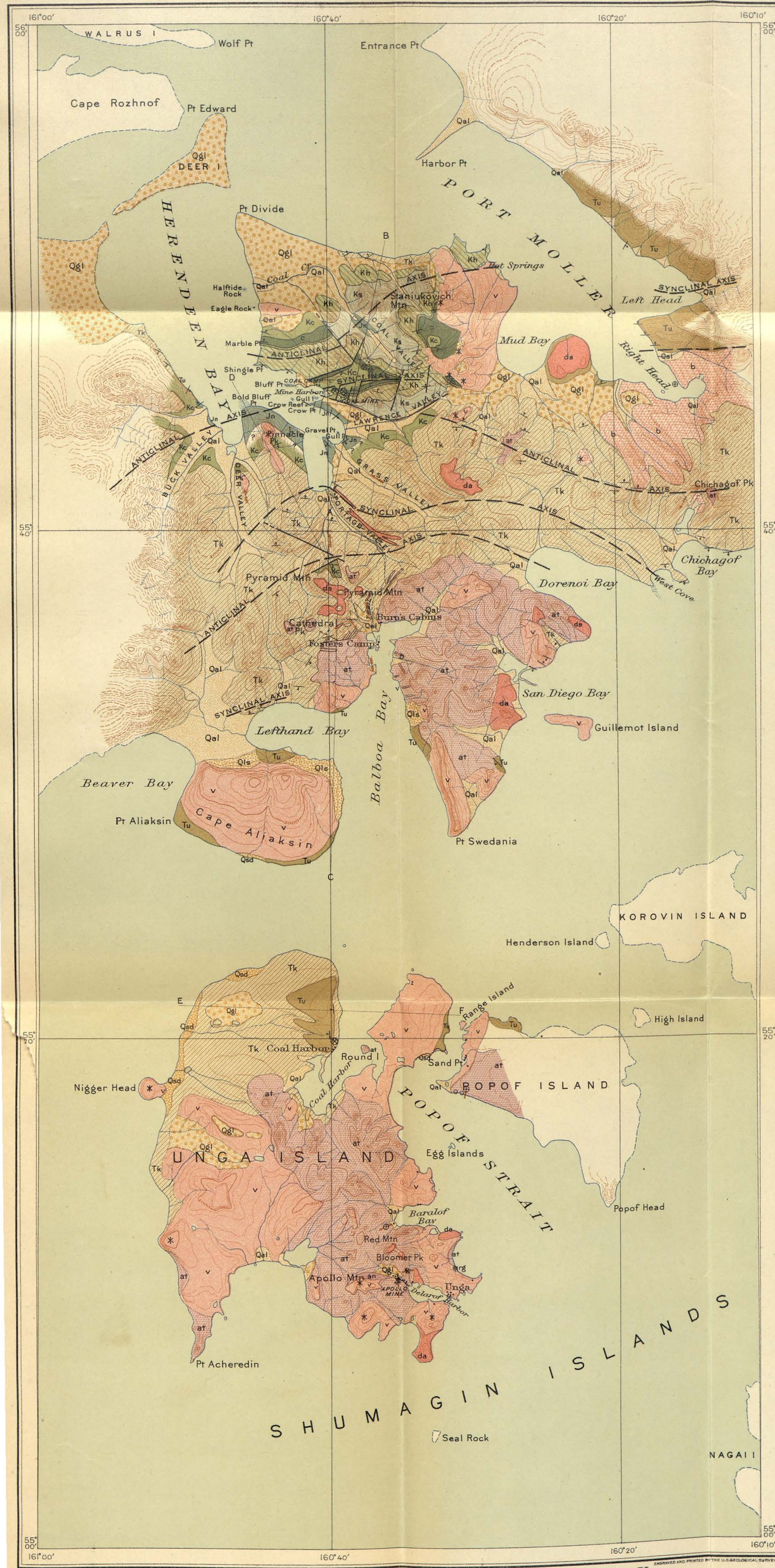

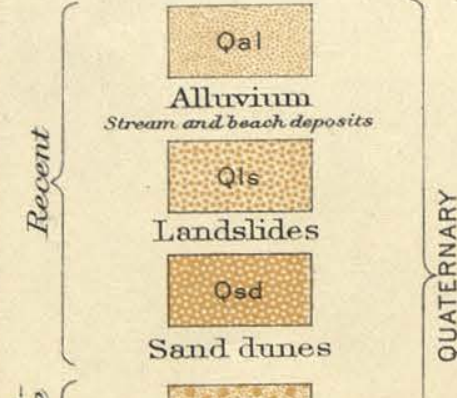

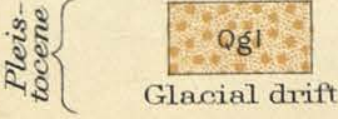

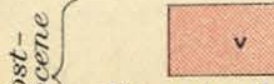

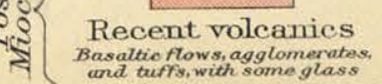

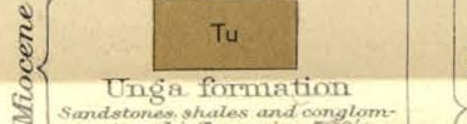

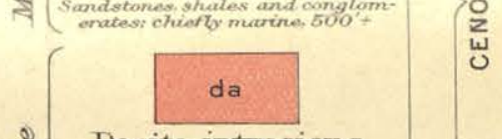

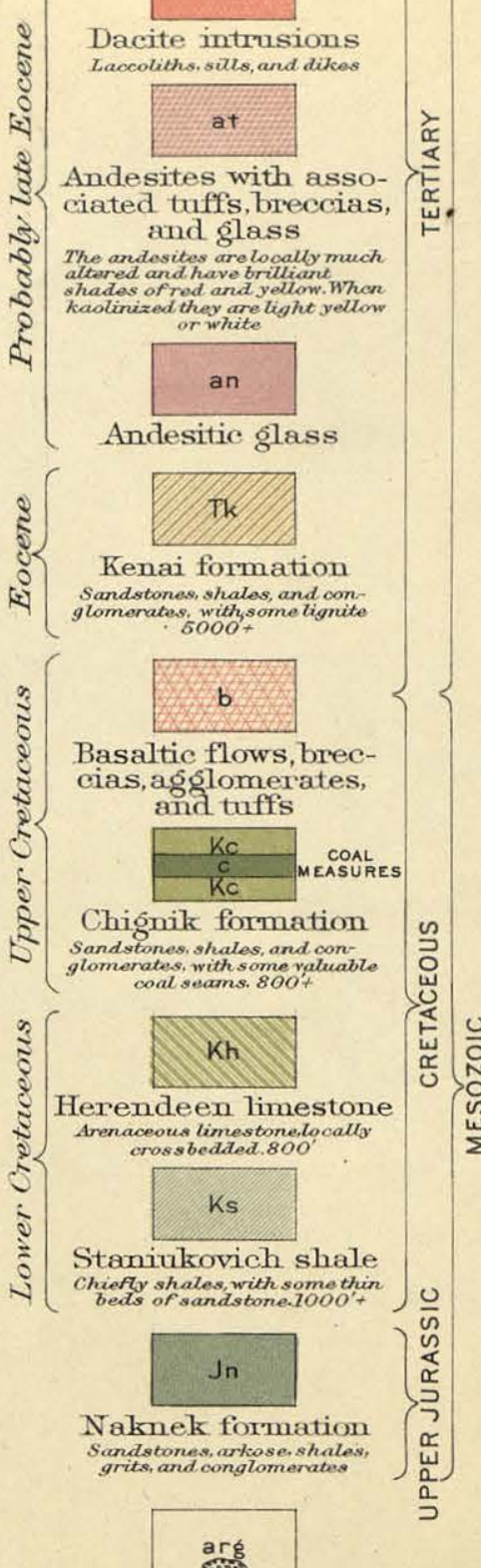
Argillite of unknown age

- Fanit

Strike and dip \begin{tabular}{|c|}
\hline Coal mine \\
\hline
\end{tabular}

Coal prospect

Gold mine

$\oplus$

Gold prospect

Gold-bearing
quartz veins

Gold placer

Copper prospect

Volcanic center

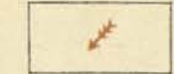

Glacial striae

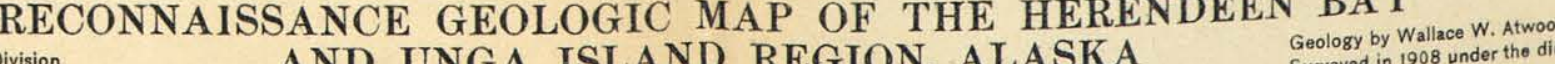


Detailed measurements of the coal measures are given on page 98 . The conglomerate overlying the coal measures, which has a thickness of about 300 feet, is well exposed in the cliff north of Coal Bluff, on the east shore of Herendeen Bay, and in the canyon portion of the valley of Mine Creek. This conglomerate contains pebbles of quartz, chert, greenstone, and sandstone, generally between 1 and 2 inches in diameter, but not uncommonly grading up to 4 inches in diameter.

Fauna and flora.--Upper Cretaceous fossil material has been secured from several localities in the Chignik Bay region. Shells have been obtained from Chignik Head just east of Anchorage Bay (collection No. 45), from points along the north shore of Chignik Bay northeast of the entrance to Chignik Lagoon (collection No. 52), from exposures on the northwest shore of Chignik Lagoon (collection No. 58), and from the southeast shore near the entrance of the lagoon (collection No. 53). Similar invertebrate collections have been secured from the coal measures exposed in Whalers Creek, northwest from the upper end of Chignik Lagoon (collection No. 51). Stanton's report on these collections is as follows:

Collections of fauna of the Chignik formation in the Chignik Bay region.

No. 45. Chignik Head, east of entrance into Anchorage Bay:

Inoceramus sp. related to I. vancouverensis Shumard.

Horizon, Upper Cretaceous or older. Similar forms of Inoceramus range down to the Jurassic.

No. 51. Whalers Creek, 2 miles above mouth of stream, Chignik Lagoon:

Anomia sp.

Inoceramus digitatus Sowerby.

Axinæa veatchi Gabb.

Meretrix nitida Gabb.

Meretrix sp.

Tellina nanaimoensis Whiteaves.

Tellina sp.

Perissolax brevirostris Gabb?

Horizon, Upper Cretaceous. The fauna is the Chico fauna of the Pacific coast especially as developed in the Nanaimo formation of Vancouver Island.

No. 52. North side of Chignik Bay, 1 mile north by east from head of sand spit:

Anomia sp.

Inoceramus digitatus Sowerby.

Axinæa veatchi Gabb.

Clisocolus sp.

Meretrix nitida Gabb.

Tellina nanaimoensis Whiteaves.

Mactra sp.

Solarium sp.

Perissolax brevirostris Gabb.

Fusus? sp.

Volutoderma sp.

Pachydiscus? sp. represented by a single immature ammonite.

Horizon, Upper Cretaceous, same horizon as on Whalers Creek. 
No. 53. Northeast of Alaska Packers' Association cannery and 200 yards southwest of native village:

Rhynchonella sp.

Inoceramus sp. Fragments.

Nucula sp.

Leda sp.

Trigonia sp.

Hamites? sp. Fragments.

Horizon, certainly Mesozoic and presumably Upper Cretaceous. The fossils indicate a different horizon, or at least a different facies, from the one represented at neighboring localities from which Cretaceous collections were obtained.

No. 58. Chignik Lagoon, about opposite Alaska Packers' Association cannery:

Anomia sp.

Inoceramus digitatus Sowerby.

Axinæa veatchi Gabb.

Meretrix nitida Gabb.

Pachydiscus? n. sp.

Horizon, Upper Cretaceous, same horizon as on Whalers Creek.

From the same series of beds which yielded the Upper Cretaceous invertebrates three collections of plant forms were procured. Knowlton's report on these collections is as follows:

Collections of plant forms of the Chignik formation in the Chignik Bay region.

No. 49. South side of Chignik Lagoon, near entrance:

Taxodium? sp.

Sequoia rigida Heer?

Pterophyllum lepidum? Heer.

Adiantum formosum Heer.

Ferns, two species.

Dicotyledons.

This I presume to be Upper Cretaceous.

No. 54. Chignik River just below Long Bay:

Trapa? microphylla Lesq.

This collection contains a large number of specimens of this species. This is very interesting, and so far as I now recall is the first time it has been found beyond the central Canadian provinces. This form of Trapa was at first supposed to be characteristic of the Montana (Upper Cretaceous), but it has now been found to have so wide a vertical range that it can not be employed in close fixation of age, though I should incline to think it probably Cretaceous.

No. 55. Chignik River just below Long Bay, 30 feet above collection No. 54 .

Pterophyllum lepidium? Heer.

Conifers, ferns, and dicotyledons.

Apparently same age as collection No. 54 .

Hollick determined collections 49 and 55 as Upper Cretaceous or lower Tertiary, but did not reach a conclusion regarding the age of collection 54 .

During the year 1904 Stanton collected some fossil material along the border of Chignik Lagoon, from about the same locality where collection No. 49 was made. These plants were identified by Knowlton and include the following Upper Cretaceous species: 
Osmunda arctica.

Sequoia reichenbachi.

Sequoia rigida.

Taxodium sp.

Torreya brevifolia.

Anomozamites schmidti.
Zamites sp.

Myrica sp.

Quercus johnstrupi.

Quercus n. sp.

Ziziphus sp.

Regarding the other material procured in this vicinity Stanton writes as follows: ${ }^{1}$

The shales above the conglomerates yielded Inoceramus fragments, Pecten, Nucula (Scila) cf. truncata, Corbula, Thracia, Dentalium, Cinulia, and some undetermined ammonoid fragments.

At the locality on Whalers Creek Mr. R. W. Stone obtained an Inoceramus, related to $I$. digitatus, a Trigonia of the type of $T$. leana, and Anomia.

These fossils indicate correlation with a horizon in the Chico as developed in California and in the Nanaimo of Vancouver Island, which include practically all of the Upper Cretaceous, but the beds at Chignik are probably not older than basal Senonian.

The identification of the Upper Cretaceous in the Herendeen Bay region rests in part upon invertebrate forms and in part upon plant remains. Invertebrate forms have been secured from the small area north of the laccolithic mountain midway between Balboa and Herendeen bays, from the south side of Pinnacle Mountain 900 feet above tide, from the base of the mountains west of the west arm of Herendeen Bay, and from the coal measures in the valley east of Coal Harbor. In these collections Stanton has recognized the following forms:

Pachydiscus multisulcatus Whiteaves.

Inoceramus sp. of type of I. cripsi Mantell.

Inoceramus digitatus Sowerby.

Paige spent a few days in the Herendeen Bay coal field in $1905^{2}$ and collected invertebrate material from the coal measures, on which Dr. Stanton made the following report: ${ }^{3}$

The lots that are the most interesting, because they are entirely new to the region, are those from the Upper Cretaceous. These are from the following localities: (1) Big exposure on left fork of Coal Creek, just above coal; (2) 200 yards above left fork of Coal Creek; (3) just above Johnson tunnel.

The last-mentioned lot contains only fragments of Inoceramus and the age is somewhat questionable, but the other two lots contain abundant and well-preserved examples of Inoceramus digitatus Sowerby, which is a peculiar type known only from the Upper Cretaceous. The same species has been found associated with coal at Chignik, and it also occurs in the coal-bearing Cretaceous rocks of Vancouver Island.

Pompeckj, who restudied the old collection of Wossnessenski from near Katmai, reports a specimen of Belemritella labeled as coming from that place, and on that account infers the presence of Upper Cretaceous there, but this lacks confirmation. The exposures north of Douglas Village have yielded a few fragmentary specimens of a large Inoceramus and a Desmoceras (?). ${ }^{4}$

1 Stanton, T. W., and Martin, G. C., the Mesozoic section on Cook Inlet and Alaska Peninsula: Bull. Geol. Soc. America, vol. 16, 1905, p. 408.

2 Paige, Sidney, The Herendeen Bay coal field: Bull. U. S. Geol. Survey No. 284, 1906, p. 301.

3 In this report the name "Coal Creek" was used instead of Mine Creek, as given on the maps accompany-

ing this report. 4 Stanton, T. W., and Martin, G. C., The Mesozoic section on Cook Inlet and Nlaska Peninsula: Bull. Geol. Soc. America, vol. 16, 1905, p. 409 . 
These specimens probably indicate the presence of Upper Cretaceous beds.

The plant collections from the coal measures near Herendeen Bay have not been entirely satisfactory, for it has not been possible, from the material secured, to determine many of the species. The marked presence of certain types of cycads indicates a Cretaceous age for the coal measures, but does not fix satisfactorily their place in the Cretaceous. From a study of the plant collections Dr. Knowlton has made the following report:

Collections of plant forms from Chignik formation of the Herendeen Bay coal measures.

No. 30. Coal series, Mine Creek, Herendeen Bay:

Sequoia langsdorfii? (Brongn.) Heer. cf. Phaseolites formus Lesquereux.

Fragments of dicotyledons.

Age uncertain, as indicated by the plants.

No. 35. Two miles up canyon west from the head of Mud Bay, an arm of Port Moller:

Anomozamites sp.

Pterophyllum sp.

Nilsonia sp.

Hausmannia sp.

Ginkgo sp.

Quercus? sp.

Betula? sp.

Taxodium or Sequoia sp.

I do not know exactly where to place this lot, as I have not been able to positively determine any species, but from the marked presence of cycads of these types I regard it tentatively as Cretaceous.

Paige ${ }^{1}$ procured an abundance of plant fossils from the coal measures exposed in the valley east of Coal Harbor, and an extract of Knowlton's report on this material is given below:

Coal Creek, ${ }^{2}$ right branch below first side stream:

Anomozamites cf. A. schmidtii Heer.

Cone, probably of Sequoia.

Fragments of dicotyledons.

Right bank of Coal Creek, first tunnel:

Sequoia sp.?

Pterophyllum cf. P. concinnum Heer?

The age of these beds as indicated by the meager plant remains is Cretaceous, and probably similar to the beds on Chignik Bay, from which Dr. Stanton obtained a Cretaceous flora.

One-half mile above left branch of Coal Creek, 200 feet above fork right branch Coal Creek, big exposure left fork Coal Creek, the plant remains, aside from a fragment of a dicotyledon, consist entirely of delicate coniferous branchlets. This species was at first supposed to be Taxodium distichum miocenum, but more careful study appears to indicate that it is an undescribed species of Sequoia. The age of these beds in uncertain, but is probably similar to that of the other lots. None of the present lots contain any of the species found in the material collected at Herendeen Bay by Townsend.

After examining the floral material collected in the Herendeen Bay region by Paige in 1905 and by the writer in 1908, Hollick con-

1 Paige, Sidney, The Herendeen Bay coal field: Bull. U. S. Geol. Survey No. 284, 1906, p. 103.

2 "Coal Creek" refers to Mine Creek (see Pl. II). 
cludes that there is in this region a floral horizon which is either Eocene or Upper Cretaceous and which "may be correlated with floral complex of the lower Yukon Valley."

Stratigraphic relations.-Nothing is known of the relations of these sediments to other rocks in the northeastern part of the peninsula, but some data from the Chignik and Harendeen Bay regions is now available. In the Chignik Bay region the Upper Cretaceous rocks (Chignik formation) rest unconformably upon the Upper Jurassic (Naknek formation). The unconformity is well shown on the northwest side of Chignik Bay, a short distance east of the sand spit at the entrance to Chignik Lagoon, and on the northwest coast of the lagoon. The relations have not been fully determined in the area west of Hook Bay, where Upper Jurassic and Upper Cretaceous rocks are known to be exposed, but a great structural unconformity probably exists at that locality. The Eocene sediments (Kenai formation) rest above the Chignik formation. The relationship at this upper contact of the Chignik formation is that of conformity. There appears to have been a long period of sedimentation in this region, extending through late Cretaneous time and nearly to the close of Eocene time, and the nature of the sediments indicate somewhat similar conditions throughout this entire period of deposition. The Chignik formation includes several seams of workable coal interbedded with sandstones, shales, and conglomerates, and in the Kenai formation lignite beds and carbonaceous shales are associated with sandstones, shales, and conglomerates.

Vast quantities of volcanic tuffs and basic lava flows overlie the Cbignik formation in the Hook Bay region north of Chignik Bay proper, and at two points in this locality are intrusions of igneous rocks. A large mass of andesitic lava appears to cut across the sedimentary rocks with a fault contact at the southwest terminus of the Chignik formation in this region.

In the Herendeen Bay region the Upper Cretaceous (Chignik formation) appears to rest at some places upon the Upper Jurassic and at other places upon the Lower Cretaceous. The former relationship must be that of unconformity, but the latter may be that of conformity. The data on this problem are not satisfactory. In Pinnacle Mountain (fig. 3), where the section has been examined with some care, Upper Jurassic and Upper Cretaceous horizons have been definitely determined, but there are several hundred feet of sediments in the midst of the section which may possibly represent a portion of the Lower Cretaceous from which no fossils were secured. In the coal field the relationship between the Upper and Lower Cretaceous sediments appears to be that of conformity, but the fossil material obtained in this part of the field indicates a faunal break which may mean an unconformable relationship. 
The Kenai formation (Eocene) rests conformably upon the Upper Cretaceous in the Herendeen Bay region. This relationship is shown on the north side of Pyramid Mountain in the central portion of the range, and on the ridge south of Pinnacle Mountain. The conditions of sedimentation in this region appear to have been about the same as those that obtained in the Chignik Bay region during late Mesozoic and early Tertiary times. In Pinnacle Mountain the Chignik formation, along with other sediments, is capped by Recent volcanic tuffs and lava flows (fig. 3). At the eastern margin of the coal field the sedimentary series is covered by great lava flows and by vast quantities of volcanic tuffs. The exposure of the Upper Cretaceous in the central portion of the peninsula midway between

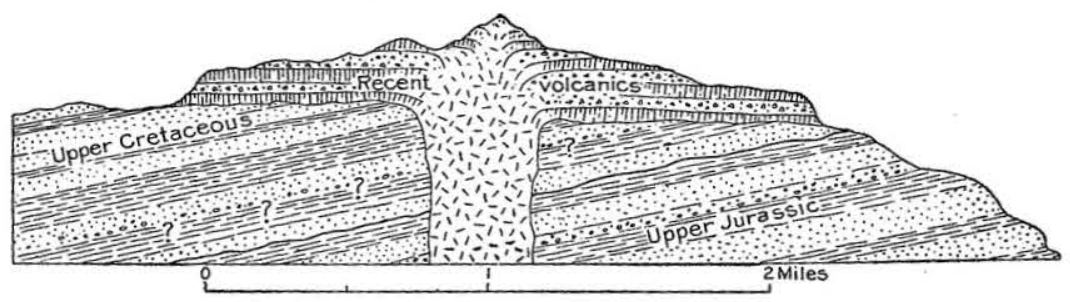

FIGURE 3.-Diagrammatic cross section of Pinnacle Mountain.

Balboa and Herendeen bays is bounded by a fault contact on the northwest, but elsewhere by the conformable series of Kenai sediments.

\section{TERTIARY SYSTEM.}

BASALTIC FLOWS, BRECCIAS, AGGLOMERATES, AND TUFFS OF EARLY EOCENE AGE.

This group of volcanic rocks was seen at the eastern margin of the field at the head of Port Moller, and although detailed study could not be made owing to lack of time, it appeared that these rocks corresponded to the "lower beds" of Palache's Stepovak series, examined by him on the south side of the peninsula near the head of Chichagof Cove. If this interpretation is correct, they are of early Eocene age and older than the other groups composed chiefly of pyroclastic rocks to be described later. At the head of Port Moller the volcanic rocks appear to be chiefly basaltic flows. Palache had a favorable opportunity to study these rocks as they are exposed near the base of Chichagof Peak, and the following description is from his report: ${ }^{1}$

The lower beds comprise coarse breccias or agglomerates and fine tuffs composed wholly of igneous material. They show only a rude stratification, but as far as it can be made out it is accordant with that of the overlying, distinctly bedded sediments. The coarser agglomerates contain angular fragments, a foot or less in diameter, of white or greenish porphyry and, rarely, granite. These are cemented sometimes by comminuted material of the same nature, sometimes by a dark greenish black compact

1 Palache, Charles, Harriman Alaska Expedition, vol. 4, 1904, pp. 74-7.7. 
material which is found, under the microscope, to consist essentially of interwoven hornblende needles. The finer-grained tuffs have a most varied appearance. One specimen is a mass of small angular fragments of yellowish porphyry, the interspaces, largely unfilled, giving the rock a cellclar appearance. Again the trff is compact, with small fragments well cemented. In places the rock is stained bright green by disseminated iron silicates (celadonite?). The impression of these rocks as broight from the field was that they were made up of material of widely varying character. But microscopic study does not confirm this impression. On the contrary, they show in all their phases, and whether the fragments of which they are composed be large or small, considerable uniformity in petrographic character. Most of the sections show porphyritic rocks with a glassy grotndmass or with one so indistinctly crystalline as to suggest a devitrified glass. Occasionally the grot:ndmass is a fine granophyric intergrowth of quartz and orthoclase. The ni:merous phenocrysts consist of acid plagioclase, less abundant orthoclase, and deeply embayed quartz crystals. The feldspars are very fresh and free from inclusions. Magnetite in minute grains seems to be the only other constituent of the rock. The rock fragments seen in the sections range in character from rhyolite to dacite porphyry, with an occasional one of granite.

The cement which binds the fragments together is in some cases clearly secondary silica, but more generally appears to be glass, in which are carried minute feldspar fragments and crystals of quartz, portions of spherulites, and occasionally sharp crystals of zircon and apatite. In one specimen, as mentioned above, the cement is a mass of felted hornblende crystals.

The pyroclastic character of these rocks is certain; in some there is slight evidence of water sorting; others may fairly be called flow breccias. To my surprise, some of them were found to contain fossil shells, for the most part of a pecten-like form. These fossils are too poorly preserved and few to furnish any basis of age comparison with those found in the higher beds. But they establish the fact that some of the tuffs at least are waterlaid deposits, however little the rocks themselves might suggest that conclusion.

Palache's Stepovak series, as defined by him, included these "lower beds" of pyroclastic rocks and a great thickness of overlying strata from which he obtained an abundance of marine invertebrate fossils of Eocene age. During the season of 1908 fossils of Eocene marine invertebrates were secured in close association with the typical Kenai flora, and the formation from which these animal and plant forms was secured was traced to the locality from which Palache secured his collections of fossil shells. These pyroclastic rocks probably indicate local volcanic outbursts early in Eocene time.

EOCENE SERIES.

KENAI FORMATION.

Character and distribution.-The Kenai formation has been recognized at various places on the peninsula and in the northwest portion of Unga Island. Cape Douglas, the northeastern extremity of the peninsula, is composed in part of Tertiary rocks, presumably of Kenai age. The Kenai formation has been definitely recognized a few miles northeast of Katmai and at many places in the Chignik Bay and Herendeen Bay regions, and has been traced over large areas. The formation is known to outcrop on the east shore of Pavlof Bay. $90054^{\circ}-$ Bull. $467-11-4$ 
The Tertiary sediments in the northeast part of the peninsula have been described as sandstones, shales, and conglomerates, with some lignite beds. They are exposed near the base of the mountains

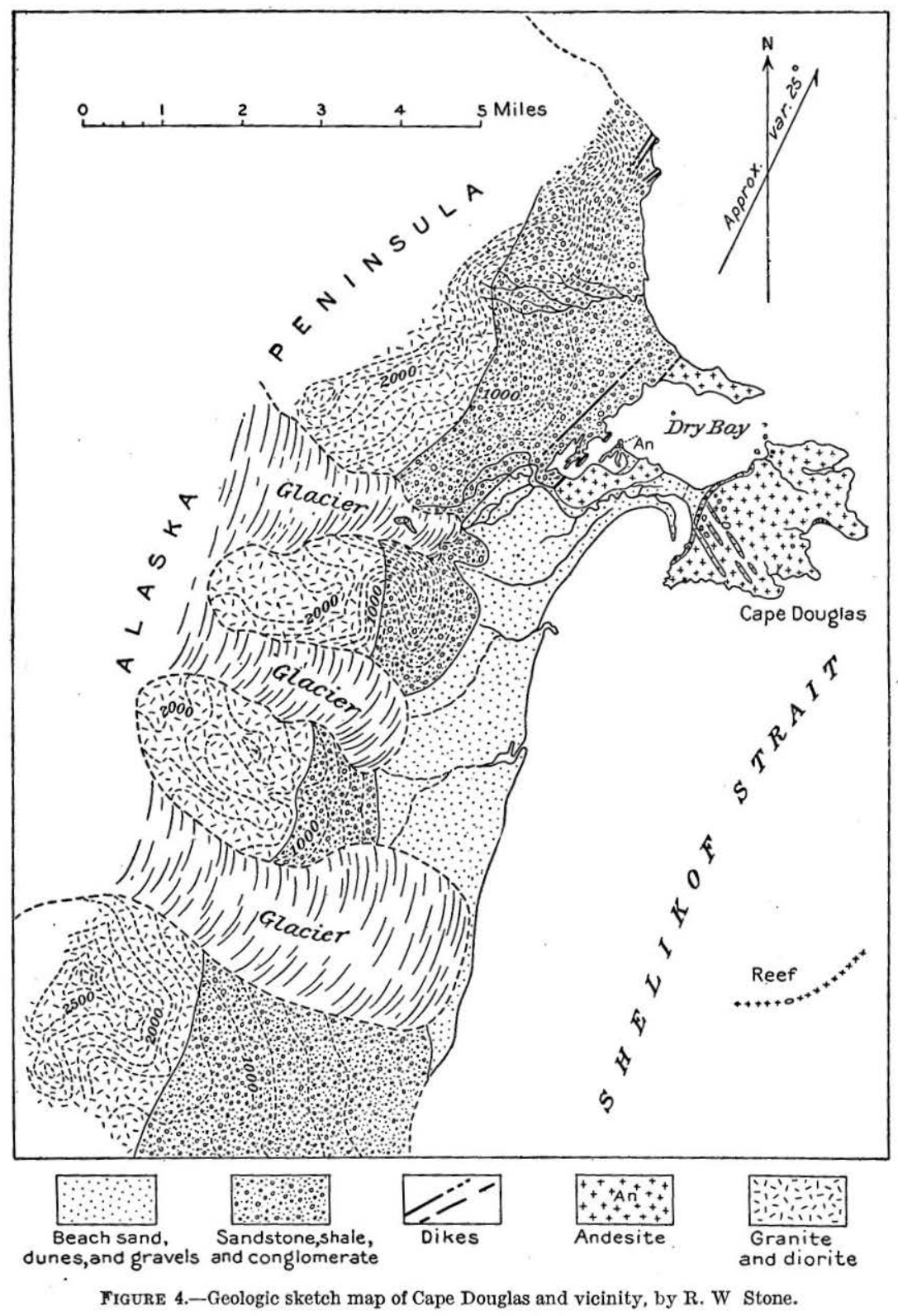

west of Cape Douglas and at several points along the shore of that cape (fig. 4). A mass of granitic rock intrudes west of the Tertiar. sediments at the northeastern extremity of the peninsula, and sur 
cessive flows of andesitic lava overlie the sediments in Cape Douglas. Between Hello Bay and Amalik there are several small areas of Tertiary rocks presumably of Eocene age (Pl. VI). At Kukak Bay, one of the small reentrants along this portion of the coast, an excellent collection of Kenai plants was obtained by a member of the Harriman expedition. The report on this collection will be referred to later.

The Kenai formation is exposed in the Chignik Bay region on the south side of the bay and southwest as far as Castle Cape, and on the southeastern shores of Chignik Lagoon and Chignik River. (See Pl. VII, p. 40.) There the formation consists of sandstones, shales, and conglomerates, with some thin beds of lignite. The thickness of the formation in the Chignik Bay region is at least 1,000 feet. Near the top of the Kenai section as exposed along the shore of Chignik Lagoon and in the bluff of Chignik River are intrusive sheets, layers of volcanic tuff, and extrusive flows. These igneous rocks become more and more abundant in these localities until the sedimentary record closes and a series of volcanic rocks succeeds.

The Kenai sediments in the Balboa-Herendeen Bay region reach a thickness of at least 5.000 feet and form the main mass of the Aleutian Range. The formation consists of sandstones, shales, conglomerates, and beds of lignite. The sandstones and conglomerates predominate in the lower half of the section and black shales in the upper part. The lower half was commonly spoken of in the field as the alternating series, for its most conspicuous feature was a series of great conglomerate beds ranging from 30 to 50 feet in thickness. This lower portion is well exposed west of the trail in the central portion of the range from Balboa to Herendeen bays. The black shales are shown to the east of the same trail and north of the west arm of Balboa Bay, as well as near the head of Grass Valley, in the central portion of the range, and in Chichagof Peak, at the eastern margin of the area shown on Plate VIII (p. 42). Part of this section was examined by Palache, ${ }^{1}$ who used the name Stepovak series in describing the sediments exposed in and near Chichagof Peak.

Where Palache examined these rocks, they were divisible into two parts, which he called "upper beds" and "lower beds." The "lower beds" comprise coarse breccias, or agglomerates, and fine tuffs composed wholly of igneous material. These beds show a rude stratification that appears to be accordant with that of the overlying distinctly bedded sediments. These pyroclastic rocks have been describerl.

The "upper beds" consist of soft shales, sandstones, and grits, which are the eastward continuations of the strata exposed between Balboa and Herendeen bays. The writer spent but little time during the season of 1908 in this eastern margin of the field, but

1 Palache, Charles, Harriman Alaska Expedition, vol. 4, pp. 69-87. 
observed phenomena seemed to accord with the determinations of Palache, and the mapping in this portion of the field is based in part upon his subdivision of the rocks. The lower or pyroclastic beds are not known to be exposed elsewhere on the peninsula. Volcanic rocks of that nature, so far as they have been studied on the peninsula, are found to be of later age than the Kenai formation. It is quite possible, however, that in the vicinity of Chichagof Peak there were volcanic eruptions in early Eocene time, and that these tuffs and breccias, which have some basaltic flows associated with them, are equivalent in age with clastic sediments elsewhere.

Along the coast west from Balboa Bay the Aleutian Range, constituting the core of the peninsula, appears to be composed of the same great series of Kenai sediments exposed in the Balboa-Herendeen Bay region. An examination of the exposures on the east shore of Pavlof Bay was made, and from those exposures collections of plants and invertebrates were secured. The invertebrates have been judged to be of late Eocene age and the plants of Kenai (Eocene) age. The series exposed on the east shore of Pavlof Bay includes sandstones, shales, conglomerates, and some thin beds of lignite. In physical and lithogical characters these rocks are similar to those elsewhere identified as of Eocene age.

The Kenai formation of Unga Island is limited to the northern and northwestern portion of that island. This locality was visited by Dall in 1685 and at various times since then. Dall has secured collections of fossil plants from the exposures on the west shore of Coal Harbor, and these plants, as determined by Knowlton, belong to the Kenai horizon. The Kenai formation in the island consists of sandstones, shales, conglomerates, and several seams of lignite. The rocks are well exposed on the shores of Coal Harbor, at points along the northwest coast of the island, and thence south along the western shore fully halfway to the southern end of the island. The Unga conglomerate, which is of Miocene age, overlies these rocks conformably on the west shore of Coal Harbor. In the lowland area the Kenai formation is in part mantled by glacial deposits, among which are numerous small lakes or ponds.

Fauna and flora.-The forms determined by Knowlton in the collection of plant material made at Kukak Bay by De A. Saunders are listed below, together with Knowlton's comments. ${ }^{1}$

1. Equisetaceæ:

$$
\text { Plant forms of the Kenai formation. }
$$

II. Pinaceæ:

1. Equisetum globulosum Lesq.

2. Picea harrimani sp. nov.

3. Picea, branches.

4. Picea?, seed.

${ }^{1}$ Knowlton, F. H., Harriman Alaska Expedition, vol. 4, pp. 158-159. 
II. Pinaceæ-Continued.

5. Pinus?, leaves.

6. Pinus?, scales of cone.

7. Sequoia heerii Lesq.

8. Sequoia, cone.

9. Taxodium distichum miocenum Heer.

10. Taxodium tinajorum Heer.

III. Juglandaceæ:

11. Juglans acuminata Al. Br.

12. Hicoria magnifica sp. nov.

IV. Betulaceæ:

13. Betula, branch.

14. Corylus macquarrii (Forbes) Heer.

15. Corylus harrimani sp. nov.

16. Corylus? palachei sp. nov.

17. Alnus corylifolia Lesq.

18. Alnus sp.

V. Ulmaceæ:

19. Ulmus braunii Heer.

VI. Aceraceæ:

20. Acer trilobatum var.

VII. Hippocastanaceæ:

21. Aesculus arctica sp. nov.

VIII. Sterculiaceæ:

22. Pterospermites magnifolia sp. nov.

23. Pterospermites alaskana sp. nov.

IX. Ericaceæ:

24. Andromeda grayana Heer.

25. Vaccinium alaskanum sp. nov.

$\mathrm{X}$. Incertæ sedes:

26. Phyllites saundersi sp. nov.

From this it appears that 9 families and 26 forms are represented. Of these families the richest, both in forms and individuals, is the Pinaceæ, to which 9 forms are referred. The most abundant conifer is Taxodium distichum miocenum, which is represented by 40 or more pieces of matrix on which there is nothing else preserved, while hardly a piece in the collection is without fragments of greater or less size. The species must have been an important element in this flora, as it undoubtedly was in other arctic floras.

On pages 161 and 162, Knowlton adds:

Of the 26 forms represented in the collection, 9 are described as new to science, 7 are not named specifically, being branchlets, seeds, scales, broken cones, etc., thus leaving 10 species previously known. These are as follows:

Equisetum globulosum Lesq.

Corylus macquarrii (Forbes) Heer.

Sequoia heerii Lesq.

Alnus corylifolia Lesq.

Taxodium distichum miocenum Heer. Ulmus braunii Heer.

Taxodium tinajorum Heer.

Juglans acuminata Al. Br.

Acer trilobatum var.

Andromeda grayana Heer.

Equisetum globulosum was described originally from Cook Inlet, Alaska, and was also detected by Lesquereux in Fort Union beds near the mouth of the Yellowstone River. Sequoia heerii was first found at Sage Creek (?), Mont., in beds of doubtful Green River age. It has since been found in the upper Clarno formation (upper Eocene) at Bridge Creek, Oreg., and is now for the first time reported from Alaska. Taxodium distichum miocenum enjoys a very wide distribution but is especially 
abundant in arctic lands. Every collection from Alaska contains numerous examples of this species. The closely allied T. tinajorum was described originally from Port Graham, Alaska. Juglans acuminata was found by Heer at Port Graham also, though first described from the European Miocene. Corylus macquarrii has quite a wide distribution, but is especially abundant in Alaska. It has also been reported from the Fort Union beds of Montana and British Columbia, and doubtfully from the Laramie. Alnus corylifolia has been reported from Cook Inlet. Ulmus braunii, described from the Swiss Miocene originally, has been reported from Kamloops, British Columbia, in strata of probably Eocene age, and from the Green River beds at Florissant, Colo. Acer trilobatum, as already pointed out, is too poorly preserved to admit of full identification. A form of this species has been found at Herendeen Bay, but it is not possible to say that they are identical. Andromeda grayana was originally made known from Port Graham, Alaska, but has since been rather doubtfully identified from one or two other localities.

From this hasty review it appears that 4 of the 10 species have never been found outside of Alaska, while the remainder are abundantly characteristic of the same region. It is sufficient to state that the named species above enumerated are typical of the socalled "Arctic Miocene," which is now regarded as of the age of the upper Eocene. The species described in this paper as new are in various ways allied to forms characterizing this horizon, and I do not hesitate to refer this collection to the upper Eocene.

No invertebrates were procured from the Kenai formation in the Chignik Bay region, but several collections of fossil plants were obtained. The localities from which these collections were obtained, together with Knowlton's comments on them, are given below:

Collections of plant fauna from the Kenai formation near Chignik Bay.

No. 46. One-half mile south of Northwestern Fishery Co.'s cannery, Anchorage Bay. Sequoia langsdorfii (Brongn.) Heer.

Sequoia couttsiæ? Heer.

Taxodium tinajorum Heer.

Populus richardsoni Heer.

Age, Kenai.

No. 47. Anchorage Bay, opposite Northwestern Fishery Co.'s cannery:

Populus richardsoni Heer.

Taxodium tinajorum Heer.

Corylus macquarrii? (Forbes) Heer.

Age, Kenai.

No. 48. Anchorage Bay, opposite Northwestern Fishery Co.'s cannery, one-half mile north of 47 :

Taxodium tinajorum Heer.

Sequoia langsdorfii (Brongn.) Heer.

Age, apparently same as Nos. 46 and 47.

No. 57. Chignik River, opposite Nun Point:

Sequoia langsdorfii (Brongn.) Heer.

Populus arctica Heer.

Populus sp.

Corylus sp.?

Hedera macclurii Heer.

Magnolia cf. inglefieldi Heer.

Diospyros sp.?

This, I think, is higher than Nos. 54 and 55 and, if the species have been correctly determined, is in the Kenai.

Hollick examined these collections and decided that they were of Eocene age. 
Dall visited this region in 1871 and collected Kenai plants from the shore of Doris Cove, which is 'just west of Anchorage Bay.

Kenai fossils have been obtained in abundance from the BalboaHerendeen Bay region, where the association of the invertebrate and plant material has led to a most satisfactory determination of the Kenai formation. Palache, in 1899, collected a large number of invertebrate fossils from the section exposed along the shores of Chichagof Cove. These were determined and described by Dall, from whose report the following extract is taken: ${ }^{1}$

Dr. Palache's party camped on the eastern side of Chichagof Cove, near the outlet of the lagoon, and the localities where fossils were obtained were noted by him as follows, the number preceding each note being that assigned the locality in our record book: ${ }^{2}$

3373. Beds near the camp on the eastern side of Chichagof Cove, belonging to what Dr. Palache has designated on his sketch chart as the "upper beds" of the Stepovak series.

3374. From the west headland of Chichagof Cove, beds similar to those of 3373 .

3375. From the east side of West Cove, the beds belonging to the upper series.

3376. From the hill above the camp, the same horizon as at the camp, but about a mile along the strike.

§77. From slope of Chichagof Peak, beds belonging to the "lower" series of Dr. Palache, near a dike. (See p. 74.)

3378. From the breccia beds of the same lower series as 3377 , on the slope of Chichagof Feak.

That some difference in age exists between the beds of the upper series is obvious, but inat this difference involves a faunal difference is not so certain, since several of the species found in the lower beds were also collected from the upper beds, and the toial number from the lower beds is too small to admit of any valuable comparison being made. If any faunal difference exists, it is probably not greater than that between the Chickasawan and Claibornian horizons in the standard Alabama column, to which we are accustomed to refer our correlations of the Eocene horizons of the east American Tertiaries.

Five species were obtained from the lower beds, one being the Venericardia planicosta Lamarck, the well-known "finger post of the Eocene," which, with two others of the five, was also obtained from the upper beds.

An enumeration of the fauna obtained by Dr. Palache now follows. Invertebrate fossils of the Kenai formation.

Porifera: Cliona alaskana Dall.

Mollusca:

Pelecypoda-

Leda sp.

Yoldia palarkei sp. nov.

Yoldia emersonii sp. nov.

Yoldia breweri sp. nov.

Nucula (Acila) decisa Conrad.

Glycimeris sp.

Ostrea sp.

1 Dall, W. H., Harriman Alaska Expedition, vol. 4, pp. 99-111.

2 The collections, including the type specimens, are in the U. S. National Museum, at Washington, D.C. 
Mollusca-Continued.

Pelecypoda-Continued.

Ostrea sp.

Pecten (Chlamys) sp.

Modiolus harrimani sp. nov.

Modiolus sp.

Modiolus alaskanus sp. nov.

Modiolus (Botula?) sp.

Venericardia planicosta Lamarck.

Phacoides? sp.

Macrocallista (Chionella?) gilberti sp. nov.

Macrocallista (Chionella) sp.

Tellina sp.

Spisula callistæformis sp. nov.

Spisula sp.

Mesodesma alaskensis sp. nov.

Gastropoda-

Drillia? sp.

Clavelithes? sp.

Chrysodomus sp.

Rimella? sp.

Cassis sp.

Cerithium? sp.

Crepidula precursor sp. nov.

?Ampullina crassatina Lamarck.

Natica sp.

Margarites peninsularis sp. nov.

Dentalium sp.

The total Eocene fauna of the Stepovak series above described thus comprises at least 34 species, and it is probable that by continued systematic collection a very much larger number might be obtained.

During the season of 1908 several collections of plants were secured in this region from leaf-bearing beds interstratified with sediments bearing Eocene invertebrates. The shell and plant bearing beds where these collections were secured are interstratified, and separated from 10 to 30 feet stratigraphically. The shells are of Eocene age, and the plants are typical of the Kenai strata. The great sedimentary series from which these fossil collections were secured forms the core of the Aleutian Range in this region. These series have been traced eastward, and are found to be continuous with those examined by Palache at Chichagof Cove, from which locality he secured so many typical Eocene invertebrates.

Knowlton's report on the plants from this formation is as follows:

Collections of plant forms from Kenai formation in the Balboa-Herendeen Bay region.

No.6. One-third mile upstream along strike of beds on south slope of the canyon coming into the head of Balboa Bay from the west:

Sequoia langsdorfii (Brongn.) Heer.

Equisetum globulosum Lesq.

Populus arctica Heer.

Hicoria magnifica? Kn.

Age, Kenai. 
No. 10. One-half mile southeast from the head of Herendeen Bay and about 600 feet above the bay:

Sequoia langsdorfii (Brongn.) Heer.

Taxodium sp.?

Osmunda doroschkiana Gopp.

Protorhipis or Hausmannia (n. sp.)

Corylus macquarrii? (Forbes) Heer.

Populus arctica Heer.

Comptonia cf. C. cuspidata Lesq. (May be new.)

Age, Kenai.

No. 11. On crest east of divide on trail to Herendeen Bay:

Populus arctica Heer.

Age, Kenai.

No. 20. West side of Herendeen Bay, opposite Marble Point:

Taxodium distichum miocenum Heer.

Taxodium tinajorum Heer.

Populus zaddachi? Heer.

Populus sp.

Populus arctica? Heer.

Hedera macclurii? Heer.

Corylus macquarrii? (Forbes) Heer.

Age, Kenai.

No. 32. Alongshore east of Point Divide between Herendeen Bay and Port Moller:

Nilsonia serotina Heer.

Betula brongniartii Ettingshausen.

Populus artica Heer.

Populus latior Heer.

Acer, probably new.

Zamites sp.

Age, Kenai or slightly later.

Hollick determined the age of the above material as follows: Collections 6, 11, and 20 as "Tertiary-Eocene" and collections 10 and 32 as Upper Cretaceous or lower Tertiary. He writes:

It is possible that those which I have indicated as "Tertiary-Eocene" may represent a flora identical with that of the upper Yukon Valley and the type locality of the Kenai at Kachemak Bay; but more extensive collections for comparison would be necessary before any positive conclusions on this point could be safely deduced.

If collections 10 and 32 are ever definitely determined to be of Upper Cretaceous age corrections on the geologic map will be necessary.

Two collections of fossil plants were made on the east shore of Pavlof Bay. Only one of them contained identifiable material. In that collection Knowlton recognized the following forms:

Collection of plant forms of the Kenai formation near Pavlof Bay.

No. 44. East shore of Pavlof Bay:

Populus arctica Heer.

Betula brongniartii Ettingshausen.

Ulmus sp.

Juglans sp.

Laurus? sp.

Age, apparently Kenai. 
Shells were found in the same section on the east shore of Pavlof Bay, the age of which, Dall says, is uncertain, though the shells appear to be Oligocene or Eocene rather than younger. No new collections of plants were made from the lignite-bearing formation of Unga Island, for the Kenai age of this formation had been previously determined.

Kenai plants have been obtained from widely separated portions of Alaska, including localities in southeastern Alaska, near Eagle, in the upper Yukon district, in the vicinity of Rampart, south of the Tanana Valley in the Ninana River district, on the lower Yukon between Nulato and Holy Cross, and at various other localities less easily designated in the interior and northern portions of Alaska. The type section is exposed on the western margin of the Kenai Peninsula along the shores of Cook Inlet, and from that locality southwest there are numerous small areas from which Kenai plants have been obtained, as well as the large area between Chignik and Pavlof bays described above.

Kenai plants were first thought to be of Miocene age; later they were considered either Eocene or Oligocene. Their Eocene age is now established beyond question. The discovery of marine invertebrates of Eocene age, in close association with typical Kenai plants, in some places on the same slab of rock, is in accord with the Eocene age determination of the plants and a pleasing coordination of the two lines of evidence. Subdivision of the Eocene in this region must await the collection of fuller faunas and floras from different portions of the section and the recognition of the significance of a great many unknown plants that have been and may be collected from this formation.

Stratigraphic relations.-The stratigraphic relations of the Kenai sediments in the northeastern part of the peninsula are not known. In the Chignik Bay region the formation is known to rest conformably upon the Upper Cretaceous and to be covered in part by volcanic rocks. No Miocene sediments have as yet been recognized in the Chignik Bay region.

The Kenai formation is known to rest conformably upon Upper Cretaceous sediments at several points in the Balboa-Herendeen Bay region. This conformable relationship is well shown in the central part of the region, on the north side of Pyramid Mountain; in Pinnacle Mountain, near the head of Herendeen Bay; and in the mountains west of the west arm of Herendeen Bay (fig. 5). In the eastern portion of the field, near Chichagof Peak, the lower Eocene beds have been described as of volcanic origin, but their base is not exposed. The relationship of the Eocene to the Miocene sediments in this portion of the peninsula is that of unconformity. The Miocene beds occur in small isolated areas about the shores, where they appear to rest 
on rocks of different ages. The Miocene in the Peninsula has not suffered the same degree of deformation that the Kenai sediments have. Where the Eocene and Miocene sediments come into contact with each other on the west shore of Herendeen Bay distinct contrasts in the dip and strike differentiate the series. The Kenai sediments in the Balboa-Herendeen Bay region have been covered in part by volcanic rocks and have been intruded by vast quantities of igneous material.

In the northwest portion of Unga Island, where the Kenai sediments are well exposed, the base of the formation can not be examined, but Miocene beds overlie conformably the uppermost Kenai sediments. Sedimentation at this place was continuous through later Eocene and into Miocene times. No notable movements appear to have affected the island at the close of the Eocene, but there was slight deformation of the sediments at the close of Miocene time.

OLIGOCENE SERIES (?).

No distinct portion of the great conformable series constituting the Aleutian Mountains in the Balboa-Herendeen Bay region can be classed as Oligocene. The invertebrate fossil material in several of the collections has been determined as upper Eocene or Oligocene. Most of the shell material, especially that which was more clearly identifiable, has been determined to be Eocene. All the plants which have been secured from the various beds interstratified with the Eocene shell-bearing horizons have been determined to be of Eocene age.

LATE EOCENE OR EARLY MIOCENE ANDESITES, TUFFS, BRECCIAS, AND GLASS.

Distribution.--In each of the areas studied in detail are considerable masses of igneous rocks composed chiefly of andesites, tuffs, and breccias so intimately intermingled that their separation on the accompanying geologic maps (Pls. VII and VIII, pp. 40 and 42) is impracticable.

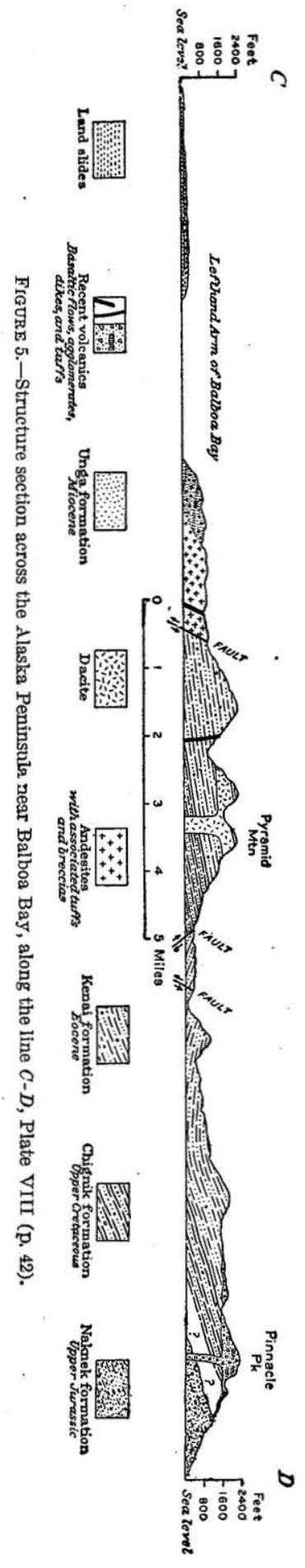


The central portion of the island of Unga is largely made up of andesites, which outcrop at a few points along the shore. Popof Island, one of the Shumagin group, which lies nearest Unga to the east, is composed chiefly of volcanic rocks, and andesites similar to those on the Island of Unga are exposed on the southwestern coast for at least 5 miles east of Sand Point. On the mainland in the vicinity of Balboa Bay there is a large but irregularly outlined area in which the principal constituents of the rocks are andesites, associated with volcanic tuffs and breccias. Andesites reach the surface at two smaller areas to the north, in the midst of the range, near the head of Port Moller. The same class of igneous rocks is exposed at the north entrance to Chignik Bay, south of the sedimentary series.

Character.-The andesites in this group of volcanic rocks are commonly dark gray or greenish, with small phenocrysts of feldspar easily visible to the naked eye. In the field these andesites were commonly described as porphyries. At many places, however, the andesites have been so altered as to present various phases of kaolinization, and from these alterations results a dense, flinty-looking matrix of dull white color. Some of the specimens include minerals that have been calcitized or chloritized, and occasionally there are minerals that are slightly epidotized. The outcrops where the rocks have been highly altered usually have deep red or yellow colors, due to the oxidation of the pyrite which is abundantly present in the rocks of those areas. Such an area of altered andesites in the central portion of Unga Island is appropriately named Red Mountain. About this center specimens showing all stages of alterations from the fresh andesites to the kaolin may be collected. A small area of deep red rocks is located about 3 miles east of the head of Balboa Bay. East and south of Red Mountain are large areas of deep yellow pyritized andesites, which have been somewhat altered.

In the Chignik Bay region, south of Chignik Lagoon, this group of volcanic rocks does not show such extreme phases of alteration as in the island of Unga and on the mainland to the north. Here the rocks are dark gray or greenish, with small white feldspar phenocrysts. Where they are locally pyritized they exhibit some discoloration from oxidation. At the north entrance to Chignik Bay the andesitic rock has a dense bluish gray matrix with small feldspar phenocrysts. The microscopic characters of a typical specimen of andesite from the island of Unga by Knopf are given below:

No. 73. Wall rock in the Apollo mine, Unga Island:

Pyritized andesite.-Under the microscope the plagioclase phenocrysts are seen to be partly chloritized and epidotized; others are reduced to an isotropic mineral, probably as opal pseudomorphs. The femic minerals are completely altered to chlorite and epidote, and as indicated by the pseudomorphs, were probably pyroxene. Pyrite occurs scattered throughout the rock in euhedral forms. No magnetite is present. The groundmass is cryptocrystalline, with a greenish tinge from the development of minute chlorite flakes. 
A specimen of the andesite taken from the mountain near the head of Balboa shows under the microscope the following characters:

No. 39. From near the summit of the first mountain directly north of Balboa Bay: Altered andesite.-Microscopically the phenocrysts are found to consist of plagioclase partly calcitized or chloritized and occasionally slightly epidotized, and chloritic pseudomorphs after pyroxene, all resting in a dense ground mass. Accessory magnetite.

These andesites have been broken and crushed, and the recementation in these crushed or sheared zones has resulted in the formation. of quartz ledges, some of which are gold bearing. Several such zones of gold-bearing quartz have been located in the southeastern part of the island of Unga, and others have been found on Popof Island and near the head of Mallard Duck Bay, an arm of Chignik Lagoon. A detailed consideration of these gold-bearing zones will be given later in the report.

The volcanic tuffs associated with this group of rocks are interbedded with the flows of andesite and the beds of breccia. These tuffs are composed of small angular fragments, many of which are of andesitic lava, embedded in a brownish groundmass. The accumulation of such tuffs during the period of volcanism varied from place to place, but usually amounted to less than 30 feet in thickness in any one locality. Good exposures of the tuffs occur on the mountain just north of the head of Balboa Bay.

The volcanic breccia included in this group of rocks is also exposed in the mountain north of the head of Balboa Bay, where it appears to be interbedded with the other rocks making up the group. The angular fragments, the largest 4 inches in diameter, are embedded in a dense brownish matrix. The description of the microscopic characters of this rock is as follows:

No. 37. South slope of first mountain north of Balboa Bay:

Altered volcanic breccia.-An altered-looking rock whose derivation is not apparent on inspection. Microscopically shows a clastic tex ture and consists of porphyritic volcanic fragments. The feldspar phenocrysts are sericitized and calcitized, the carbonate showing sporadically a rhombohedral development. Flecks of limonite are common. The groundmass is cryptocrystalline.

There is a considerable formation of andesitic glass near the southern portion of the island of Unga not far west of the head of Delarof Harbor. This glass shows distinct flow structure. It is light gray in color and in places somewhat porous. Some pitchstone is included within the area mapped as andesitic glass on Plate VIII, (p. 42). The pitchstone, which is exposed near the stream used by the Apollo mine for water power, is of greenish and yellow colors, with a dull waxy luster. The technical description of this andesitic glass is as follows: 
No. 2. North slope of Apollo Mountain, Unga Island:

Flow-banded andesite glass.-Microscopically, eutaxitic glassy lava containing sporadic feldspar phenocrysts; the flow bands average $1 \mathrm{~mm}$. in thickness and produce a thinly laminated structure. Microscopically, a few feldspar phenocrysts $\left(A b_{1} A n_{2}\right)$, sporadic prisms of hornblende, and crystals of magnetite are found embedded in a varicolored glass.

The glass appears to underlie the younger basaltic flows and to be closely associated with the andesites which form the central portion of the island. The age of the glass would, if that interpretation is correct, be late Eocene or early Miocene.

Relations to other rocks.-These andesites, tuffs, breccias, and glass appear to be the core of the land mass in the island of Unga, and are probably the oldest igneous rocks exposed on the island. They are unconformably overlain on the eastern shore of the island by Miocene beds which are in turn unconformably overlain by recent basaltic flows and coarse tuffs that rest in places upon this andesitic group. The dactites in this island (Pl. VIII, p. 42) appear to have intruded the andesites. Glacial deposits overlie the andesites in small areas. Eocene rocks outcrop at several places near sea level about the head of Coal Harbor, near which point are outcrops of the andesitic lavas. The relation of the igneous to the sedimentary beds at this point is not known.

On the mainland, in the vicinity of Balboa Bay, these igneous rocks are in part intruded as sills into the Kenai formation and in part overlie that formation. They are in turn manteled unconformably by much younger volcanic rocks of a basaltic nature. Certain dactites, to be described later, have been intruded into this andesitic group at various places. The small areas of andesites in the core of the range in the Balboa-Herendeen Bay region are intrusions into the Kenai formation.

Some andesitic lavas have intruded the Kenai formation, in the Chignik Bay region, and in some places andesites apparently overlie the Eocene sediments in a conformable relationship. The contact west of Chignik River, where the igneous rocks cut off the various sedimentary formations there exposed, appears to have been due to faulting.

Age.-From what has already been stated it is clear that these volcanic rocks are of late Eocene or early Miocene age. In the exposures north of Balboa Bay and at certain localities in the Chignik Bay region, it appears that volcanism began toward the close of Eocene time. The andesitic lava intruded the series of clastic sediments and poured out on the surface. Explosions following the beginning of this volcanic activity yielded fragmental materials that accumulated as tuffs and breccias. These rocks may, therefore, be considered late Eocene or early Miocene, or, perhaps better, transitional - in part, late Eocene and in part early Miocene. 
U. S. GEÓLOGICAL SURYẼYY

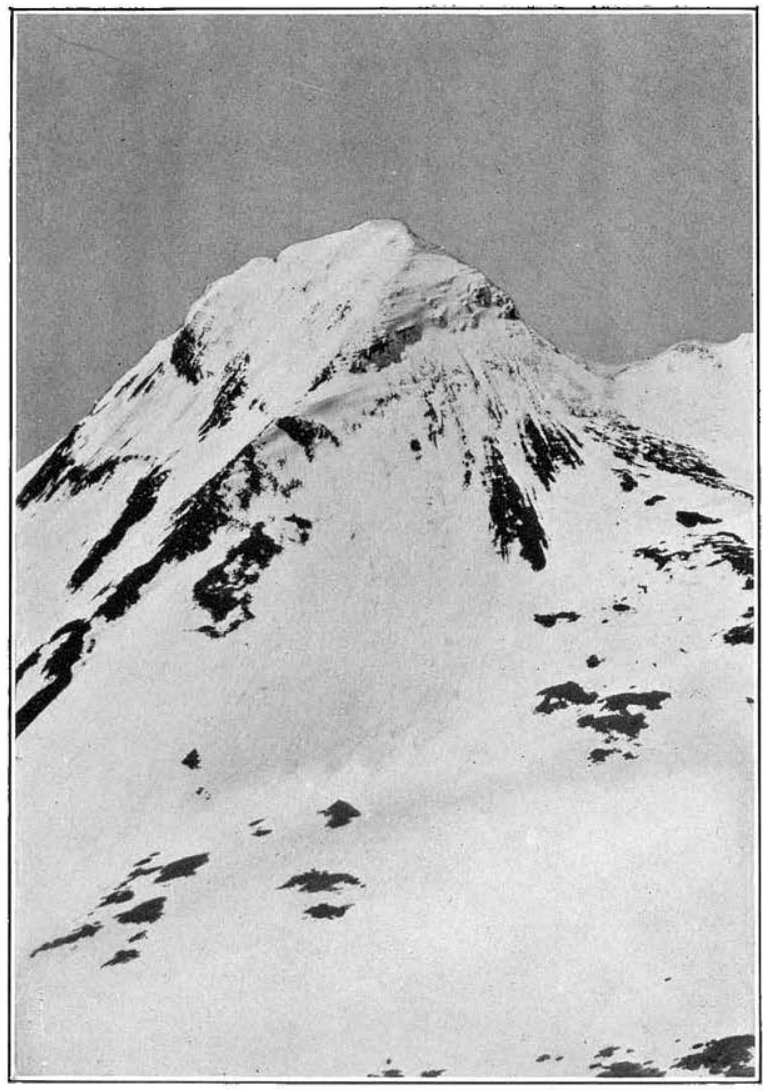

A. PYRAMID MOUNTAIN, NEAR AXIS OF ALEUTIAN RANGE NORTHWEST FROM BALBOA BAY.

A laccolithic mountain with Kenai sediments at the summit. See page 63 .
BULLETIN 487 PLATE IX

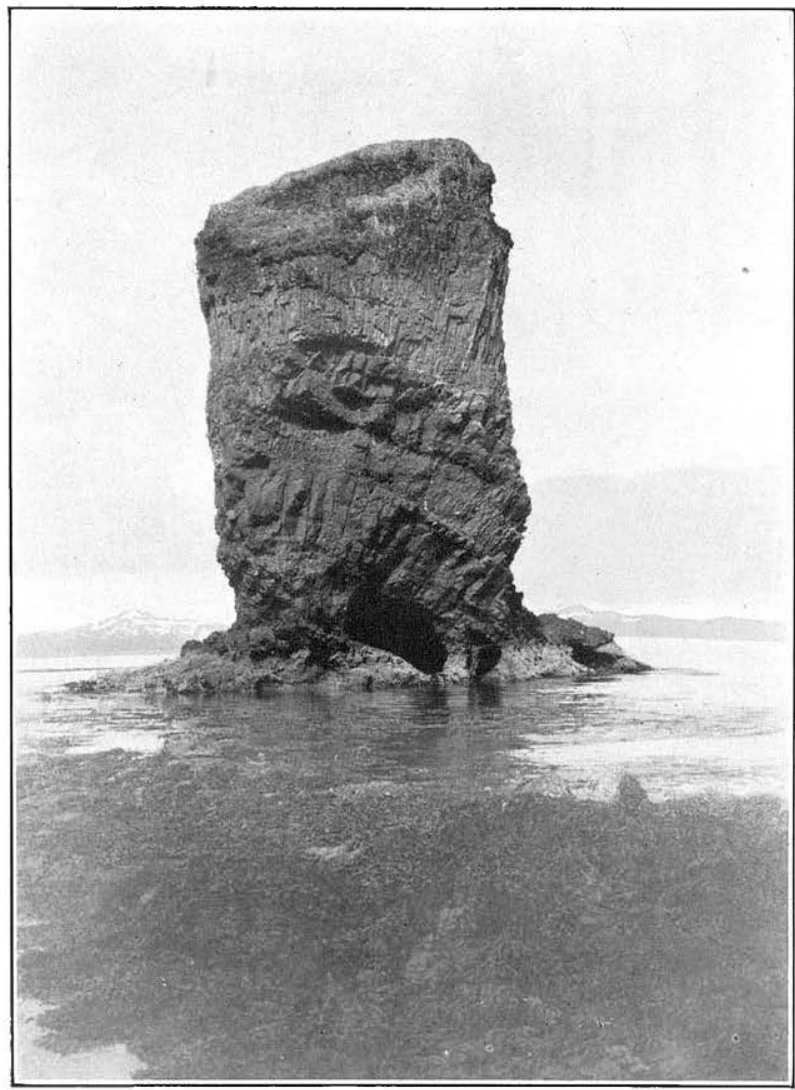

B. SHORE LINE STACK OR PILLAR ON EAST SHORE OF UNGA ISLAND.

Composed of basaltic lavas and volcanic tuffs. See pages 71, 92 . 

LATE FOCENE OR LATER IGNEOUS ROCKS.

The igneous rocks included in this class have intruded, in some places, the andesitic rocks just described, in other places the upper portion of the Kenai formation (Eocene), and in one locality the Unga formation (Miocene). They form or are associated with conspicuous topographic features in the Balboa-Herendeen Bay region.

AUGITE PORPHYRY FLOW BRECCIA.

One of the most conspicuous peaks in the Balboa-Herendeen Bay region, about 6 miles west from the head of Balboa Bay, is composed of a flow breccia with the general characters of an augite porphyry. This mountain has sharp pinnacle features that reach an elevation of about 2,500 feet and has been appropriately called Cathedral Peak (Pl. III, $B$, p. 12). The same flow breccia appears in the next mountain east of Cathedral Peak somewhat below the summit, with Kenai sediments above and below. The igneous rock is high in the Kenai section, and therefore of late Eocene age.

Knopf's description of this rock is as follows:

In the hand specimen the vitreous brown augites embedded in an aphanitic brown matrix are the most conspicuous feature. Microscopically it proves to be a glassy augite porphyry flow breccia containing numerous fragments of various kinds of andesite. Considerable chloritization has affected the rock.

DACITES.

Distribution.-Dacites are exposed in several areas on the island of Unga and on the mainland in the Balboa-Herendeen Bay district (Pl. VIII, p. 42). The areas on the island of Unga are in the south portion of the island within a few miles of the village of Unga. On the mainland to the north the dacite exposures are in the higher peaks just west of the trail between Balboa Bay and Herendeen Bay. Other masses of dacite have intruded the sedimentary rocks southeast of Herendeen Bay and still other small areas occur on the Pacific coast east of Balboa Bay.

Pyramid Mountain is located in the central portion of the peninsula southwest of the head of Balboa Bay. It is a conspicuous snowcapped peak (Pl. IX, $A$ ) and rises to an elevation of about 2,500 feet. The main mass of the mountain is composed of the Chignik and Kenai formations (fig. 6). Near the summit, except for the upper 100 feet, which consists of Eocene sediments, the mountain is for the most part dacite.

The dacite exposed in Pyramid Mountain is part of a large laccolithic mass, from which outliers extend westward, forming the crests of two mountain ridges. A large amount of dacite was removed in the development of the valley between these mountain ridges. The dacite attains a maximum thickness of about 1,000 feet near Pyramid Mountain, from which point the mass becomes gradually thinner in all directions. 
The dacite mass west of Santiago Bay forms a somewhat conspicuous mountain of light-gray color. The masses of dacite farther east appear to have intruded the andesitic lavas and tuffs, and the mass bordering the coast appears as a great intrusive sheet. The area a little back from the coast forms a conspicuous knob 2,000 feet in height.

Of the dacite areas in the southeastern portion of Unga Island, those bordering the coast appear as bold cliffs that weather to a light gray color. The areas inland form low knobs along the crest of the mountain ridge. Dacite-like lavas have been seen in the Chignik Bay region, but the mapping has not been carried out in sufficient detail to differentiate those masses from the dacite proper.

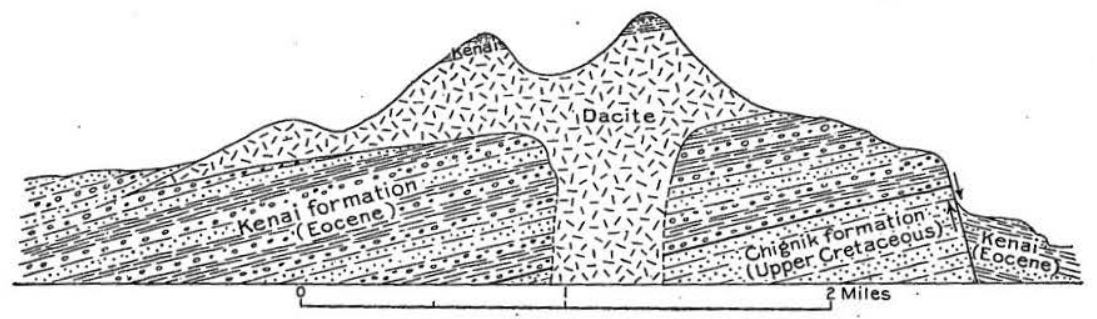

FIgure 6.-Diagrammatic section of Pyramid Mountain.

Character.-The dacites have a porphyritic texture, with dull white phenocrysts of feldspar and glassy quartz in a gray or light greenish groundmass. The microscopic description of a specimen taken from the large laccolith in the central portion of the range northwest of Balboa Bay is as follows:

No. 53. From Pyramid Mountain laccolith (Pl. VIII, p. 42).

Dacite.-Microscopically, the quartzes are found to be powerfully resorbed, the plagioclase $A b_{1} A n_{1}$ to show marked zonal banding, and the hornblende prisms are in places chloritized. The alteration of the rock as a whole, however, is unimportant. The groundmass is unusually well individualized for these volcanics; it consists of small stout plagioclases and interstitial quartz and probably some orthoclase. The accessories are magnetite, apatite, and titanite.

Reiations to other rocks.-On the mainland the intrusions of dacite are in the form of sills, dikes, and laccoliths; the structural relations in the large laccolith northwest of Balboa Bay are shown in figure 6. The mass of dacite is about 1,000 feet thick and extends over an area of several square miles. Remnants of the sedimentary formations overlie the igneous rock in two of the higher peaks (Pl. VIII). The large mass of dacite in the central portion of the range and east of the head of Herendeen Bay is not so clearly shown to be of laccolithic form. This intrusion is also into the Kenai formation. East of Balboa Bay along the coast and in the southern portion of Unga Island the dacite masses appear to have intruded the andesites described above. 
Age.-It appears from the evidence just presented that the dacites are all late Eocene or later, for they cut late Eocene sediments and late Eocene or early Miocene volcanics at several places. At the head of Port Moller dacites cut and overlie Miocene sediments. They are probably all older than the basaltic flows and tuffs soon to be described.

$$
\text { DIORITE PORPHYRITE. }
$$

The determination of this rock was made by Palache. The only known exposure of this type of igneous rock is in the Chichagof laccolith (fig. 7). Chichagof Peak reaches an elevation of a little more than 3,000 feet. It is about 4 miles northeast from the head of Chichagof Cove and near the eastern margin of the area shown on

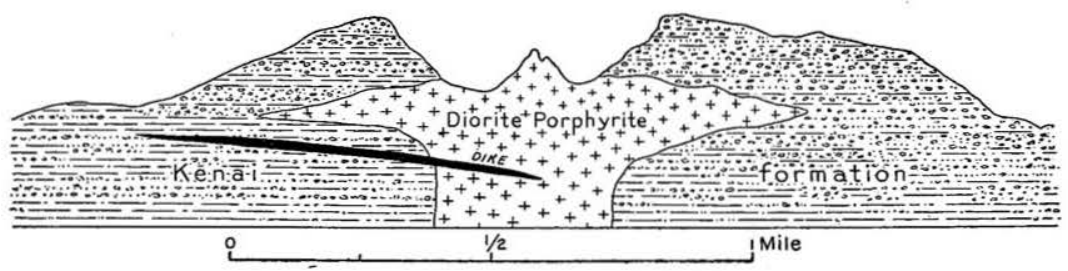

FIGURE 7.-Diagrammatic section of south face of Chichagof Peak. After Palache.

Plate VIII (p. 42). The main mass of the mountain is composed of the Kenai formation. Near the base there are several hundred feet of volcanic tuffs and breccias, and the laccolithic mass here referred to and shown in figure 7 is near the summit. The rock ranges in color from gray to greenish gray and has a distinctly porphyritic texture. Palache states that the intruded rock is well exposed near the summit of Chichagof Peak, and that dikes are numerous in the vicinity of the laccolithic mass. The dikes are reported to be in a general way radial to the dome-shaped uplift of the peak, and hence to cut across the strike of the sedimentary beds at high angles. The description of one of the microscopic sections, by Palache, ${ }^{1}$ is as follows:

Diorite-porphyrite.-Grayish green rock with many stout prismatic green hornblende crystals, in fine gray matrix, which stand out on weathered surface. Groundmass of minute green hornbrende needles and basic plagioclase microlites less in amount. Phenocrysts labradorite and hornblende. Labradorite very abundant in sharply bounded crystals, twinned on albite and Carlsbad laws, very fresh and free from inclusions. Hormblende colorless to pale green, fibrous, in short stout sharply terminated crystals, sometimes inclosing a small core of colorless pyroxene, but clearly original. Chlorite almost the only decomposition product, replacing some of the groundmass hornblende. Quartz is absent.

1 Palache, Charles, Harriman Alaska Expedition, vol. 4, p. 80. $90054^{\circ}-$ Bull. $467-11-5$ 
MIOCENE SERIES.

UNGA FORMATION.

Character and distribution.-Dall gave the name Unga conglomerate to the sediments of Miocene age which he examined on Unga Island. At that locality the formation is predominately conglomeratic, but at the many other localities indicated on the maps accompanying this report the formation does not include much conglomerate, and accordingly the term Unga formation is used here. This formation was first recognized by Dall ${ }^{1}$ in the western portion of

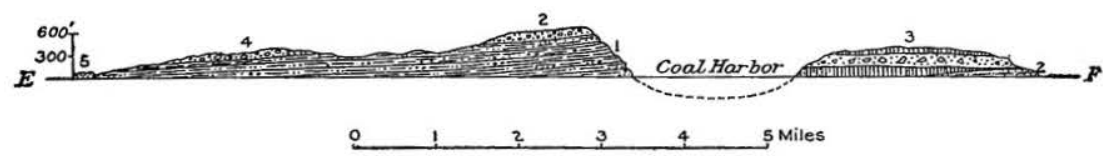

FIGURE 8.-Structure section at the north end of Unga Island, along line $E-F$ on Plate VIII. 1, Kenai formation (Eocene); 2, Unga formation (Miocene); 3, recent volcanic rocks, basaltic flows, and tuffs; 4 , glacial drift; 5 , sand dunes.

Unga Island, where it overlies the Eocene lignite-bearing beds (fig. 8.) At this locality Dall measured, in 1872, the following section:

Measured section of the Unga conglomerate on Unga Island, Alaska.

1. Tuffs and soil.

[Section includes 200 feet.]

2. Conglomerate of fine pebbles.

3. Conglomerate of larger bowlders.

4. Sandstone with marine fossils ( 1 foot).

5. Thin friable sandy shales ( 6 inches).

6. Conglomerate like No. 2.

7. Very coarse conglomerate (2 feet).

On the following page Dall, in describing the formation, states:

In the.conglomerate(Nos. 6 and 7) many pieces of rolled silicified wood were found, some of which were bored by teredos. These beds are evidently a beach formation, presaging the depression which followed in which the marine bed above them was laid down. I have called them the Unga conglomerates; and the marine stratum, which will be referred to later, from the great abundance of Crepidula proerupta Conrad, I have called the Crepidula bed. It conformably overlies the others, and there can be no doubt of the continuity of the sedimentation through the whole series of lignitic and marine strata in this locality.

The conglomerates in this type section contain large quantities of volcanic fragments which do not appear to be water worn, and therefore suggest eruptions in the immediate vicinity during a period of sedimentation.

Miocene sediments have now been found at several other localities. They are exposed on the northeast shore of Unga Island, on the northwest coast of the island of Popof, at several points on the shores of Balboa Bay and the Pacific side of the peninsula near that bay, on the west shore of Herendeen Bay and along the margin of Port Moller.

1 Dall, W. H., Coal and lignite of Alaska: Seventeenth Ann. Rept. U. S. Geol. Survey, pt. 1, 1896, p. 807. 
At each of these localities the Miocene appears to be limited to a small area, except on the northeast shore of Port Moller, where it is at least 1,000 feet thick and appears to extend for some distance north and east of the exposed face. It is possible that it will be found to be overlain in that direction by Recent volcanics. The exposures at the west entrance to Balboa Bay and on the west arm of that bay suggest by the nearly horizontal position of the strata that they underlie Cape Aliaksin, an island-like mass now tied to the mainland by an alluvial deposit (Pl. VIII). At each of the localities in the Balboa-Herendeen Bay region and on the island to the south the formation consists of sandstones, shales, and conglomerates, some of which are but loosely cemented. In the exposures along the shore of Port Moller the rocks consist of sandstones, many of which show cross-bedding, shales, grits, and conglomerates containing pebbles of quartz, flint, basalt, greenstone, and porphyry. This series has a fossil stratum carlying an abundance of oyster shells. Dikes and sills of a porphyritic basalt have intruded the Miocene section along the shores of Port Moller.

The section on the south side of the west arm of Balboa Bay is as follows:

$$
\text { Section of Miocene sediments near Balboa Bay. }
$$

Shales with sandstone concretions...................... 50

Sandy shale with sandstone concretions................... 40

Sandy clay with concretions........................ 30

This section is exposed for about 3 miles along the beach. The upper surface has been worked over by the waves and shows a distinct sea terrace about 100 feet above mean tide. The formation includes seams of lignite 2 to 3 inches in thickness. These lignite stringers occur locally in the form of lenses. The beds dip gently to the south, passing below heavy beds of volcanic tuff. Leaf fragments and bits of carbonized wood are included in some of the sandstone blocks which have fallen from the cliff, and worm tracks are abundant in some of the sandstone layers.

In the small area of probable Miocene on the west side of Herendeen Bay the sediments are for the most part unconsolidated. They yielded one-leaf collection which has been determined to be of postKenai age, and since the physical nature of the beds and the general field relations are similar to those in the known Miocene areas, this small area has been considered of Miocene age.

The small area of Miocene sediments on the east side of Balboa Bay is about 200 feet thick. The beds consist of clays, sandy clays, grits, sandstone, concretions, one 4-foot bed of heavy sandstone, and some carbonaceous shale. Some leaf fragments and bits of carbonized wood were seen, but no specimens suitable for identification were obtained. At this outcrop the dip varies from $5^{\circ}$ to $15^{\circ}$ to the southward, and the strike is west $15^{\circ}$ south. The Miocene 
beds in this locality have been beveled by the action of the waves at 50 and 100 feet above mean tide, at which elevations are remnants of sea terraces.

Fauna.-Shells have been found in abundance at all but one or two of the localities mapped as Miocene on Plate VIII (p. 42). These shells have been submitted to Dall, who, although he has not reported the specific names of the fossils, has recognized them as of Miocene age. In commenting upon the collections secured from the northeast corner of Unga Island and the northwest shore of Popof Island, he calls them "Upper Eocene, corresponding to the Unga horizon." The collection secured from the north side of the left arm of Balboa Bay "appears to belong to a horizon near to, or identical with, that of the Astoria beds, Oregon." The collection from the northeast side of Port Moller "indicates the Unga horizon containing Mytilus middendorffii Grewingk and other characteristic species." The collection from the west side of Santiago Bay is determined to be

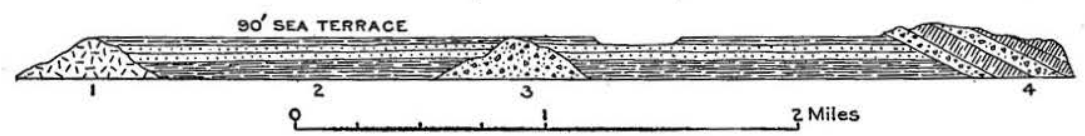

Figure 9.-Structure section along the northeast coast of Unga Island. 1, Andesite; 2, Unga formation (Miocene); 3 , tuffs; 4 , recent basalt flows and tuffs.

Miocene. An impression of a bivalve secured from the mainland just north of Unga Island was determined as "probably Marcia oregoneus Conrad from the Astoria horizon of the Miocene."

Flora.-One collection of plants determined by Hollick to be probably of Miocene age was recovered from a small area of partly consolidated sediments on the west side of Herendeen Bay, about opposite Marble Point.

Stratigraphic relations.-As has been already stated the Miocene in the northwestern portion of Unga Island rests conformably upon the Eocene (fig. 8, p. 66). There is a scattering of glacial drift over the surface, but otherwise the formation is not covered at this locality. Along the northeast coast of Unga Island the base of the formation is exposed at one or two points (fig. 9) where the andesitic group of volcanic rocks come above sea level. At this locality the formation is clearly overlain unconformably by recent basaltic flows and coarse tuffs. Conditions similar to those in the northeast portion of Unga Island prevail in each of the Miocene areas near Balboa Bay and west of Santiago Bay. The base of the formation is not exposed, but the overlying rocks are volcanic tuffs, which rest unconformably upon the little disturbed clastic sediments. The small area, probably of Miocene age, on the west shore of Herendeen Bay, is unconformably related to the Jurassic and Cretaceous sediments at the south. At the north the relationship to the Eocene is either due to an unconformity or to faulting. 
The base of the series was not recognized about the shores of Port Moller. Andesitic lavas cut through and overlie a portion of the Miocene area at the south end of Port Moller and glacial drift mantles another portion. Farther east the Miocene comes into contact with volcanics along what is believed to be the fault plain. The upper surface of the Miocene was not examined northeast of Port Moller, but from a distance the formation appears to be overlain unconformably by volcanic rocks.

At no one of the localities are the Miocene beds much disturbed. They are nearly horizontal or occur in gentle folds. In the northern portion of Unga Island the base of the formation varies in elevation about 500 feet in a distance of 5 miles (fig. 8, p. 66). The Miocene beds on the peninsula have undergone much less deformation than the Eocene beds, and except at a few localities the Miocene probably rests unconformably on formations older than Eocene.

POST-MIOCENE BASALTIC FLOWS AND TUFFS.

Distribution.-In this class are included the great masses of recent volcanic rocks consisting chiefly of basaltic flows and coarse volcanic tuffs. Such rocks have been reported from all parts of the peninsula that have been visited by geologists. Spurr refers to the axial portion of the Aleutian range in the northeastern part of the peninsula as composed of Tertiary-Quaternary volcanic rocks (PI. VI, in pocket). He reports also that in this chain of mountains as seen by him in crossing from Naknek to Katmai there are several volcanic peaks, some of which have been recently active. In the Chignik Bay region are vast quantities of coarse black volcanic tuffs in the vicinity of - Hook Bay (Pl. VII, p. 40), and the basaltic dikes of this same period of volcanism cut through formations in this region at various places. A large portion of the island of Unga is mantled by volcanic tuffs and recent basaltic flows. North of Unga, in the Balboa-Herendeen Bay region, recent volcanic rocks occur in various portions of the field (Pl. VIII, p. 42). They are conspicuous about the shore of Balboa Bay and eastward. The summit of Pinnacle Mountain near the head of Herendeen Bay is composed of volcanic tuffs and recent basaltic flows (fig. 3, p. 48). An area of nearly 100 square miles extending southward from Hot Springs on the west side of Port Moller is covered by recent volcanic rocks of the same nature as those just described. Westward from Pavlof Bay the peninsula and neighboring islands are reported to consist wholly of recent volcanic rocks.

Character.-When seen from the beach or from a boat while coasting along the shore these tuffs appear to be composed of black and dark brown fragments in a matrix of about the same colors, but when a hand specimen is examined the matrix is commonly seen to have a dark green color. The fragments included in this tuff 


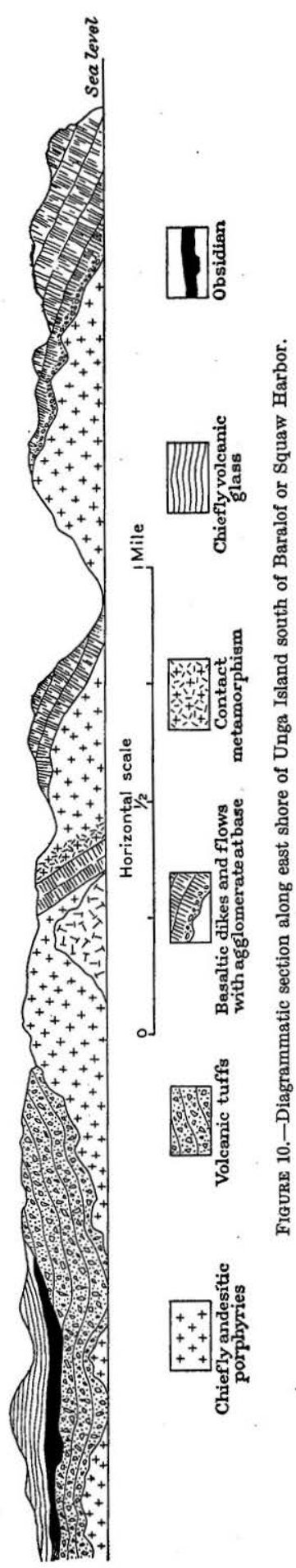

range up to 20 feet in diameter; commonly their dimensions vary from 3 to 6 feet (Pl. $\mathrm{X}, B)$. Individual blocks display the darker shades of red, green, and gray. Some of the blocks are distinctly black, and all of them show a scoriaceous texture. The tuff is poorly stratified, but appears to have been in part, at least, laid down in water. One marine shell found in the tuff just west of Balboa Bay has been identified by Dall as of Miocene age, but some uncertainty exists as to whether this shell was washed from the Miocene sediments into the sea when the tuffs were being deposited or whether the shell was left by a form living in the waters when the tuffs were laid down. Several volcanic centers associated with these recent tuffs and flows have been located. Volcanic tuffs and associated basaltic flows reach a thickness of at least 1,200 feet on the west shore of Balboa Bay.

Relations to other rocks.-Sections on the northeast corner of Unga Island show clearly that these tuffs are younger than the Miocene sediments, on which they rest unconformably (fig. 9, p. 68). The exposures in the recent volcanic tuffs and basic flows about the shores of Unga Island exhibit complex relationships which, when worked out in detail, will reveal a remarkable history of volcanism for this island. The diagrammatic section given in figure 10 shows the more easily apparent conditions along the east shore between Delarof and Baralof harbors, which is included in the view shown in Plate V, $B$ (p. 38). In this section is the small mass of argillite of unknown age already described, as well as areas of the older volcanic series of the island, which are at this locality chiefly andesitic porphyries. The upper surface of this older series of volcanics has certainly been modified by erosion, and at the base of the new series, in places, volcanic agglomerates occur. The later series includes vast quantities 


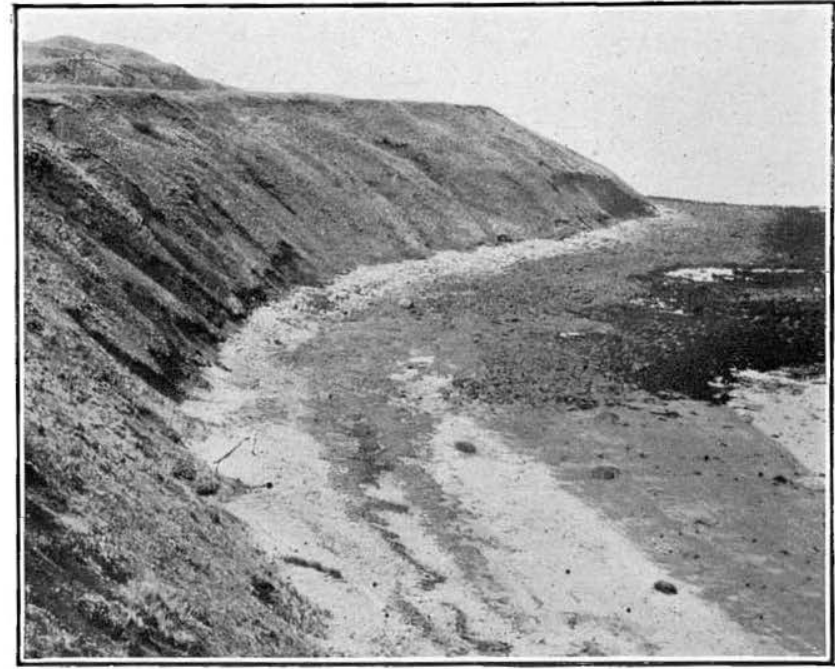

A. EleVATED SEA TERRACE AT NORTHEAST END OF UNGA ISLAND. Miocene beds are exposed in the cliff below the terrace level. See page 66.

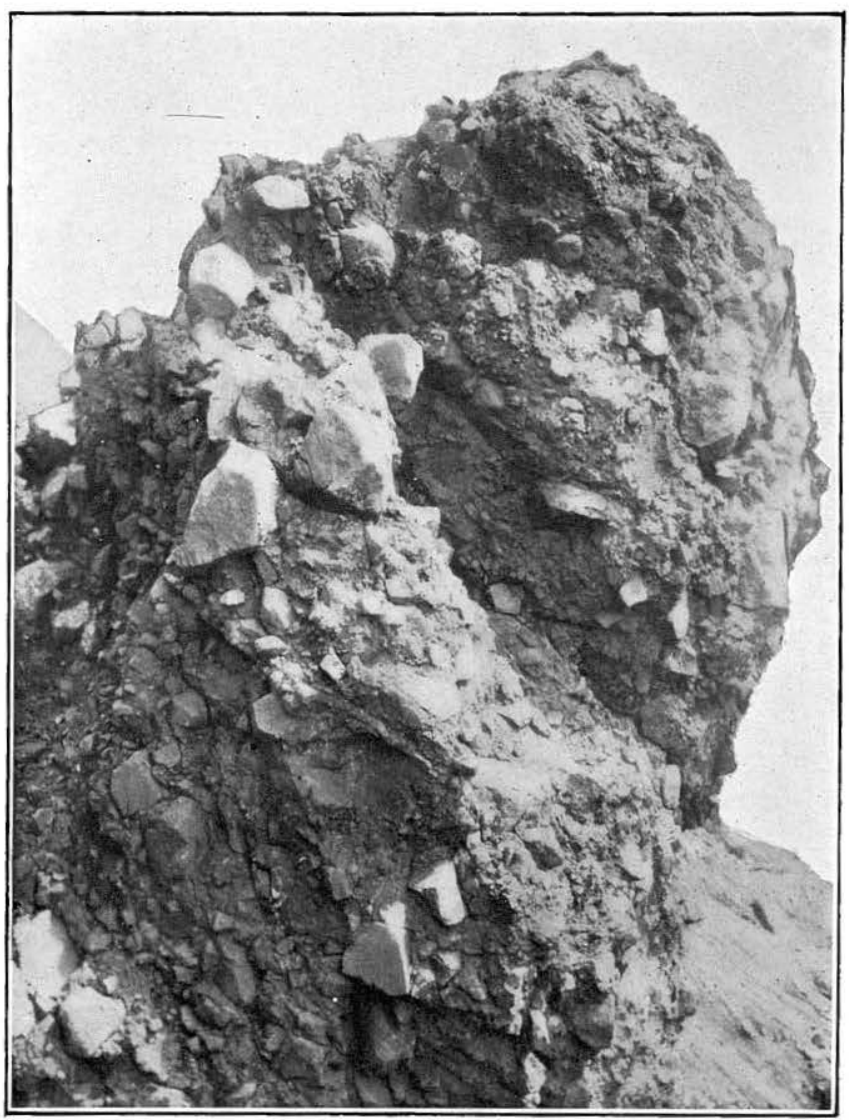

B. DETAILED VIEW OF COARSE VOLCANIC TUFF OF POST-MIOCENE AGE AS EXPOSED ON SHORES OF BALBOA BAY.

See page 70 . 

of tuffs, which are remarkably well bedded. Locally they are much deformed. A considerable amount of volcanic glass is associated with the younger volcanics exposed in this cliff, and local metamorphism has taken place where basaltic masses have intruded the earlier andesitic rocks. Since the cessation of volcanism in this part of the island, stream erosion has developed new valleys that have been lately modified by ice action, and the waves have been actively at work modifying the coast. The rock pillar shown in Plate IX, $B$, is composed of recent volcanic rocks. This pillar has been separated 300 feet from the main cliff by the work of the waves.

The recent volcanic rocks on Popof Island appear to rest upon a very uneven surface. This unevenness presumably resulted from a period of erosion after the close of Miocene time and before the renewal of volcanic activity that brought these rocks to the surface. Recent volcanic rocks clearly overlie the Miocene at several places on the mainland north of Unga Island. On the north side of the peninsula, near Herendeen Bay and Port Moller, they rest on the eroded surface of various Mesozoic and Tertiary formations. The youngest sediments upon which they are known to rest in this portion of the field are of Eocene age, but they will probably be found to overlie the Miocene east of Port Moller. The most recent volcanic rocks in the Chignik Bay region come into contact with the Upper Cretaceous (Chignik formation) near the north entrance to the bay. They are clearly younger than the Chignik formation, but basaltic dikes that are believed to be of the same age cut Eocene sediments in the vicinity of Chignik Lagoon.

Age.-These volcanic rocks are chiefly of post-Miocene age, and may all be post-Miocene. In the region studied they are, for the most part, pre-Pleistocene, but it is certain that similar formations are to-day accumulating about the active volcanoes.

PLIOCENE SERIES (?).

A small area of sediments on the west shore of Herendeen Bay, which has been classed and represented on the map (Pl. VIII, p. 42) as Miocene, yielded a collection of plants which, though not satisfactory for close determination, were judged by Knowlton to be of Miocene or Pliocene age, and since there were several similar small areas of Miocene beds bordering the coast, this area has been tentatively classed with them. The possibility remains, however, that there are some sediments of Pliocene age at that locality.

SUMMARY OF THE IGNEOUS ROCKS.

The igneous rocks thus far known in the Alaska Peninsula may be grouped in two classes. In one of these should be placed the coarsely crystalline rocks in Mount Douglas and in the northwestern 
part of the peninsula, west of Becharof and Naknek lakes. These rocks have been described as granites and syenites. They are certainly pre-Upper Jurassic, and from data obtained just beyond the limits of the peninsula it appears that they are Lower or Middle Jurassic. The full extent of these rocks is not yet known. The Mount Douglas area is probably limited to a small group of peaks at the northeast terminus of the peninsula. The igneous rocks at the extreme northwest outcrop in a belt roughly parallel to the axis of the peninsula, and probably extend for more than 100 miles in a northeast-southwest direction.

The other group of igneous rocks is chiefly of volcanic origin. These rocks include basaltic and andesitic flows, breccias, some volcanic glass, and vast quantities of tuffs. Near the volcanic centers dikes, sills, and laccolithic intrusions are exceedingly common. The rocks in this class are of Tertiary or later age. They are irregularly distributed from the northeast extremity of the peninsula, at Cape Douglas, to the western terminus near Unimak Pass and are the predominant formations in the neighboring islands. Where detailed mapping has been done these volcanic rocks have been found to be in part of early Eocene age, in part of late Eocene or early Miocene age, and in part late Miocene and post-Miocene. In fact, the association of these igneous rocks with the Tertiary and Quaternary sediments is such as to indicate that volcanic activities have probably been continuous in this portion of Alaska since the beginning of Tertiary time.

The earliest of the Tertiary lavas have been considerably metamorphosed. Later Tertiary lavas appear exceedingly fresh, while some lavas of Quaternary age are unconsolidated fragments that have very recently issued from volcanic vents. The metamorphism of the earlier Tertiary lavas has changed in a most notable degree the colors and physical properties of these rocks. Large areas of these lavas are colored in brilliant reds and yellows, and at other places the weathered material is a dull white. Knopf has drawn the following general conclusions from a microscopic study of specimens of these weathered lavas:

In many of the volcanics the alterations represented by chloritization of the ferromagnesian minerals and kaolinization of the feldspars are such as are produced by simple weathering; in others, however, the alteration has taken on a propylitic aspect, as first noted by Becker at Delarof Harbor.

The most intense alteration is shown by the pyritized andesites. In them the ferromagnesian minerals have been converted into chlorite and epidote, the feldspars have been replaced by calcite and partly epidotized, and a more or less thorough alteration has affected the ground mass. Pyrite occurs scattered throughout the rocks and is embedded in both primary and secondary minerals. There has, however, been no great introduction of new material. The iron originally contained in the femic minerals and in the magnetite was sufficient to supply that necessary for the production of the pyrite. Carbon dioxide and hydrogen sulphide appear to have been the main 
agents of alteration. The calcitization of the plagioclase feldspars implies necessarily that there has been an elimination of soda from the altered andesites.

Several vents beside the active volcanoes in the peninsula have but recently been scenes of great activity. Fragmental materials lie about each of them in vast quantities and a further study of the geology of the peninsula will undoubtedly show numerous other areas where volcanic rocks have been poured out on the surface and widely distributed by explosion. Many of the headlands bordering the Pacific Ocean owe their resistance to firmly cemented pyroclastic rocks, while others that well resist the action of the waves are composed of the denser andesitic flows that have issued from neighboring volcanoes.

\section{QUATERNARY SYSTEM.}

PLEISTOCENE DEPOSITS.

Character and distribution.-The Pleistocene deposits consist of unconsolidated clays, sands, gravels, and glacial drift. Quantitatively the glacial drift is perhaps chief in importance among these deposits. The distribution of glacial drift in the areas studied in detail during the summer of 1908 is shown on Plates VII and VIII (pp. 40 and 42). It was impracticable in the mapping to indicate the distribution of glacial bowlders, or a mere scattering of glacial drift in the valleys, but the extent of the larger masses that mantle or obscure the underlying formations has been indicated on the maps. Pleistocene deposits have not been studied in detail elsewhere on the peninsula, and from the various reports that have been given it would appear that such deposits are not conspicuous. It is probably safe to infer that there is more or less glacial drift associated, as a mantle, with the northwestern lowland of the peninsula. Such was found to be the case in the lowland area bordering Herendeen Bay, where there is a mantle of glacial drift from 10 to 30 feet thick. In the western and northwestern portion of the Island of Unga several square miles are mantled by glacial drift, and morainic deposits occur in certain of the larger valleys. In the discussion of glaciation that will be given later in this report it will be shown that most, if not all, of Unga Island has been glaciated, and that a little glacial drift may be expected almost anywhere in the lowland portions on the island.

On the mainland north of the peninsula there are but small patches of glacial drift associated with the mountain areas. The only considerable areas where there are glacial deposits are on the north side of the peninsula, bordering Herendeen Bay, and at the head of Port Moller (Pl. VIII, p. 42).

Small patches of glacial drift occur in the interstream areas northwest of Chignik Bay (Pl. VII, p. 40), others on the shores of Chignik 
Lagoon, and at least two small patches near the east end of Chignik Lake. The work in this region could not, in the time available, be carried far from the shore. It is quite probable that there is much more glacial drift in the valleys northwest of Chignik Bay and on the lowlands bordering the range to the northwest.

At each of the localities specified the drift has the physical heterogeneity characteristic of glacial till, and as there are in all the parts of the peninsula and the neighboring islands that have been studied many varieties of rocks the drift has a striking lithologic heterogeneity. Many of the stones are smooth and striated, and the material is for the most part unassorted.

The topography of these glacial deposits is of two types. On the lowlands the surface of the drift contains numerous undrained depressions bordered by low moundlike hills. It has the typical rolling topography of the ground moraine left by continental ice sheets over lowland areas. In many of the depressions are ponds or small lakes; in others are swamps, the remnants of former lakes. In the mountain valleys the deposits are distributed as lateral or medial moraines, and commonly have a ridgelike form characteristic of mountain valley moraines.

Stratigraphic relations.-The Pleistocene deposits rest upon upturned and eroded sedimentary rocks that range in age from late Jurassic to Miocene, and upon still younger volcanic formations. It is probably true that the outwash from certain of the glaciers that formerly existed here rests conformably between a series of offshore deposits of Quaternary age, but such deposits can not yet be studied.

The glacial drift in the regions mapped in detail by the author is probably all of Pleistocene age. The ice certainly left the lowlands, and quite probably the basin regions, about Chignik Bay, Unga Island, and Herendeen Bay, long before the occurrence of the last notable movement, which elevated the lands of the peninsula and adjoining islands at least 100 feet above sea level. Elsewhere on the peninsula glaciers lingered long after Pleistocene time and among the higher mountains, especially at the extreme northeast, cven until the present time. There is, therefore, post-Pleistocene glacial drift in the peninsula, and further studies in this portion of Alaska may determine criteria for distinguishing the Pleistocene from the post-Pleistocene glacial deposits.

Topographic relations. - The morainic deposits are on the side slopes at some places in the valleys. Many of these deposits are at the junction of a tributary valley with the main valley and rest upon the dividing ridge, partly as lateral moraines, and, where they have united, as medial moraines. One remarkable glacial moraine on a high ridge separates two large valleys in the western portion of 
Unga Island and forms in that place the crest of the ridge. This fact indicates that most of the western portion of the island was under jce at the time the moraine was deposited. The greater part of the glacial drift, however, is in the lowlands, where the valley glaciers deployed and where the conditions for deposition and for preservation have been more favorable. General conditions during the Pleistocene epoch and the work of the glaciers in the different regions studied will be described later.

RECENT DEPOSITS.

Pumice.-Fragments of pumice have been seen in two localities on the north side of Chignik Bay, one of these localities being in the valley of Bear Creek, where there is a considerable deposit. The fragments range up to 6 inches in diameter. This deposit appears in a small knoll or short ridge in the bottom of the valley, and must have been formed since the main valley was excavated. The source of this material may have been within the area to the east mantled by recent volcanic rocks, and where volcanic centers have been located. The other locality where pumice occurs is about 2 miles from the head of Hook Bay on the mountain southwest from the harbor. These mountains are of volcanic origin and some fragments of pumice are associated with the vast quantities of fragmental material about them.

Alluvium.-Deposits of Recent alluvium, which consists of unconsolidated sands, clays, and gravels, occur in the valley bottoms and along the shores. In the areas where mapping has been done in detail (Pls. VII and VIII, pp. 40 and 42 ) it is noticeable that at the head of each bay and in the lower part of each of the larger valleys there are bottom lands mantled by Recent alluvial deposits. These deposits have the forms of great flood plains and bayhead deltas.

Along the shores the Recent deposits take the form of sand bars, sand spits, hooks, or barrier beaches. They consist of sands and gravels worked over by the waves and distributed along the beach by waves, undertow, and shore currents. Hook Bay (Pl. VII, p. 40), north of Chignik Bay, has received its name from a sand and gravel deposit. Prospect Bay (fig. 18) owes its harbor to a sand and gravel hook developed there by the action of the waves and currents. Chignik Lagoon is but the upper end of Chignik Bay, shut off in part by a sand spit. Doris Cove is nearly closed by a sand spit, and Anchorage Bay (Pl. XI, B, p. 86) is protected by a similar form. Sand Point, on Popof Island, is appropriately named. The head of Santiago Bay is nearly closed by a sand bar, and Chichagof Cove has been shortened by the development of a barrier beach. Alluvial sediments extend upstream in all the larger valleys until they reach an elevation of about 100 feet above 
sea level. Distinct marine terraces too small to be indicated on the map appear along the shores of the mainland and of the islands at about 100 feet above sea level, and upon these terraces are Recent alluvial deposits. In places such deposits include glacial material that has been worked over by the waves. The terraces indicate unquestionably that the water stood about 100 feet higher relative to the lands in very recent time, and that during that period the alluvial lands at the heads of the bays and in the larger valleys were covered by marine waters. Since the uplift of the land the sea terraces have been somewhat dissected by streams, and in places mantled by wash from higher lands. The heads of the bays gradually uncovered by the rising of the land have come to be bottom lands of the larger valleys, and the alluvial material brought by the streams has been spread over them.

Landstides.-At a few places on the shores of Balboa Bay large areas have been so affected by landslides that it would be difficult, if not, indeed, impossible, to find exposures of the underlying rock formations. These localities have been indicated on the map as landslide areas. Landslides have occurred at many other places, but not to such an extent as totally to obscure the underlying geology, or to demand recognition on the areal map. The cliffs that have yielded most readily to the development of landslides are composed of volcanic tuffs. The areas on the west arm of Balboa Bay are developed where Recent volcanic tuffs are underlain by soft and only partially consolidated Miocene sands and clays, a condition very favorable for the development of landslides.

Sand dunes.-On the northwest shore of Unga Island, at one point on the east side, and on the coast of the mainland north of Unga Island, are sand-dune areas of sufficient extent to be indicated on the map. Dunes are also common along the Bristol Bay coast line and southwest along the shore of Bering Sea.

Glacial drift.-There are certainly glacial drift deposits on the peninsula of post-Pleistocene or Recent age. They may be expected among the higher mountains in the northeast portion of the peninsula and on the slopes of some of the volcanic peaks at the extreme southwest.

\section{GEOLOGIC HISTORY.}

From the nature and distribution of the sediments, as now known, some inferences may be drawn as to the distribution of land and water at different times in the history of the peninsula. The structure and structural relations indicate the geologic periods in which deformation took place, and the relations of the igneous rocks to the sedimentary rocks indicate the periods of volcanism and mark phases of intrusion, extrusion, and volcanic outbursts. 
EARLY MESOZOIC TIME.

The granitic rocks in the northern portion of the peninsula that are known to be of pre-Upper Jurassic age, the report of similar rocks on certain of the islands in the Shumagin group, and the conglomeratic and arkosic nature of the Upper Jurassic sediments all indicate that in early Mesozoic time masses of coarsely crystalline igneous rocks were exposed in parts of the peninsula, at least.

The Triassic rocks, which are limited so far as is now known to a small area on the southeast side of the peninsula and near the northern line, consist chiefly of sandstones, limestones, and shales. The limestones and the shells they contain indicate that the waters were shallow and marine, and at times clear. The clearness of the waters during the limestone-making periods shows either that there was little or no land near, or that the land was very low and therefore yielded little detrital material for streams to carry to the sea. The shales indicate that the waters became muddy at times, perhaps from quickening of stream work due to a slight uplift of neighboring lands, or possibly from the formation of new lands. The Upper Triassic beds have not been found in contact with any older rocks, and are consequently the most ancient rocks known in the peninsula. During a period of deformation at the close of Triassic time portions of the sea bottom on which Upper Triassic sediments had been deposited were lifted above the water. Erosion began with the uplift of this land. Valleys were developed, and the rock material that had been uplifted was in part returned to the sea to be deposited again in younger formations. This period of erosion may have continued throughout early Jurassic time, for no Lower Jurassic rocks have yet been certainly recognized on the peninsula.

With the approach of mid-Jurassic time considerable areas in the northeastern portion of the peninsula were submerged, and over these submerged areas gravels, sands, and clays were deposited to a depth varying from 1,500 to 2,500 feet. The full extent of the Middle Jurassic sea in this part of Alaska is not yet known, but the work of Stanton and Martin has shown that the waters covered a large part of the present land area on the east side of the peninsula in the vicinity of Cold Bay. The shales, sandstones, and conglomerates resulting from the consolidation of the sediments washed into the Middle Jurassic sea could have come only from land relatively near. The absence of limestone suggests that the waters were not free from land-derived sediments over any considerable areas, or for any considerable length of time during this period.

The close of mid-Jurassic time was not, so far as is now known, marked by any great physical revolution. The relationship between the Middle and Upper Jurassic rocks appears to be that of conformity, 
which would indicate that sedimentation continued from midJurassic time on into late Jurassic time without interruption. More extensive studies may show, however, that this continued sedimentation did not prevail throughout the peninsula.

The Naknek formation, which represents late Jurassic time on the peninsula, is, according to present information, more widespread than any older formation. The accumulation of at least 1,000 feet of sandstones, conglomerates, and arkoses during late Jurassic time, and the distribution of these sediments from the northeastern portion of the peninsula as far to the southwest as Herendeen Bay, indicate that the sea was shallow over a considerable part of the area now known as the peninsula, and that the sources from which such sediments were derived were not far distant from the present outcrops of the Naknek formation.

The structural relations between the Upper Jurassic and the Lower Cretaceous rocks are not known, and it is therefore impossible to state exactly the conditions at the close of late Jurassic time or the opening of early Cretaceous time in this portion of Alaska, or to define clearly the line of demarcation between the two.

\section{LATE MESOZOIC TIME.}

Lower Cretaceous rocks have been recognized in only one small area in the peninsula, just east of Herendeen Bay. If beds of that age are absent elsewhere in the peninsula it may be either that the rest of the peninsula existed as a land area or that the Lower Cretaceous rocks have been uplifted above the sea and carried away by erosion. In the area mentioned they include at least 1,800 feet of rocks, 800 feet of which are arenaceous limestone and the rest chiefly shales, with some sandstone. The shales and sandstones indicate that there was land near by, but the limestone overlying the shales show that the waters were clearing, possibly because of a slight lowering of the neighboring land, or even a depression of land below sea level, or a-reduction of the land to a level so low that little detrital material was carried from it into the neighboring sea.

At the close of early Cretaceous time there was probably sufficient movement to interrupt sedimentation, for the available data indicate an unconformable relationship between the Lower and Upper Cretaceous rocks. This disturbance may have resulted in widespread erosion over most of the peninsula lands. The sea again encroached upon the peninsula at the beginning of late Cretaceous time and covered areas in the vicinity of Herendeen Bay, Port Moller, Chignik Bay, and far to the northeast near Douglas village. Whether the sea was then continuous between these points is not known, but it is possible that most of the present lands of the peninsula were submerged during this time. The conglomerates, sandstones, shales, and 
coal indicate, however, that land was near at hand. The coal beds show that there were large swamps or marshes near sea level containing luxuriant vegetation. The swamps were submerged by slight oscillations of the land relative to sea level, and sands, clays, and gravels were deposited over the accumulated vegetable matter. Later similar marshes came into existence through a slight upward movement that brought the sea bottom just to or above the water level, and in these marshes additional vegetable matter was accumulated. In time, by another slight oscillation, this later vegetable material was buried by sediments derived from some near-by land. Such conditions continued throughout the period. of deposition of the material that formed the coal measures. No decided physical change took place in this part of Alaska at the close of Upper Cretaceous time.

\section{TERTIARY TIME.}

The similarity of the Eocene sediments to those of late Cretaceous age and their conformable relationship indicate a continuation of the same physical conditions from the beginning of late Cretaceous time to the close of Eocene time. The early Tertiary sediments are at least 5,000 feet thick in parts of the peninsula, and consist of shales, sandstones, grits, conglomerates, and some lignite. The sandstones, shales, grits, and conglomerates are not unlike those formed in the preceding period, and like them indicate that land areas were near at hand. The beds of lignite indicate that conditions favoring dense growths of vegetable matter alternated with conditions favoring accumulation of sandstones and shales. The peninsula was subject to slight changes of position and stood by turns a little above sea level and a little below the water surface. Such minor oscillatory movements commonly precede great periods of deformation, and the close of the Eocene epoch was marked by orographic movements and volcanic activities so distinct as to prove that the Alaska Peninsula was no exception to the rule.

The distribution of Eocene sediments indicates that the oscillatory conditions above described existed very generally over the southwestern part of the peninsula and at places, at least, along the eastern coast farther north. To what extent the Eocene sediments have been removed from places where they once existed can not now be told.

These early Tertiary sediments have not yet been found in a horizontal position at any place on the peninsula or neighboring islands, but have been upturned in each of the areas. In the Chignik Bay region they are gently folded, and farther west, even to Pavlof Bay, they form the great anticlinal arch in the core of the peninsula.

Miocene sediments have not been found upon the Eocene except at one locality in the northwestern portion of Unga Island, where they 
rest conformably upon the Eocene. This conformity would indicate that Unga Island was not involved in the general orographic movement that marked the close of Eocene time on the peninsula. The movement that affected the sediments on Unga Island occurred a little later.

The orographic movements that marked the close of Eocene time brought certain portions of the peninsula above water, in this way modifying the shore line and determining new areas favorable for sedimentation. It appears that many small bays or inlets where such sediments could be deposited existed at the beginning of Miocene time. These bays do not appear to have been formed entirely by the original structural features, and may therefore have been formed in part by erosion following the period of deformation at the close of the Eocene and in part by a slight depression of the land which allowed the sea to enter the lower portion of the larger valleys. Miocene sedimentation was in progress along the coast line, as is shown by the small areas of Miocene rocks on the borders of the peninsula and neighboring islands. It is fair to assume that the small areas now existing are mere remnants of Miocene sediments formerly much more extensive.

Volcanic activities were distinct in this portion of Alaska near the close of Eocene time, or at the beginning of Miocene time. In the upper Eocene there are great laccolithic intrusions and numerous dikes and sills. In addition to these igneous rocks, extensive flows of andesite, some flow breccia, and local accumulations of volcanic tuffs appear to have followed the deposition of upper Eocene sediments. It is not certain that this period of volcanism ceased during the period when Miocene sediments were being deposited, but it is certain that at the close of Miocene time, or later, great masses of igneous rocks were intruded into the sedimentary series.

The close of Miocene time was marked by a lesser deformation than that which occurred at the close of Eocene time, but this later movement was sufficient to upturn and to fold gently the Miocene sediments at most of the places where they have been discovered. The periods of volcanism which marked the close of both the Eocene and the Miocene times were associated with periods of deformation. When periods of volcanism and deformation coincide lavas approach the surface more readily than at other times and gain access to the surface through the weakened or broken crust of the earth.

The deformation which marked the close of the Miocene epoch modified the coast line of the peninsula and probably raised a greater land area than the present peninsula above sea level. This conclusion is based upon the absence of Pliocene sediments, so far as now known, from the peninsula, which leads to the inference that at least the present area of the peninsula was above water, and upon the 
drowned coast line indicated by the numerous and in many places fiordlike bays, which shows that there has been a recent depression of the peninsula and therefore an advance of marine waters over portions of what had just previously been land. This depression may have taken place just before, during, or after Pleistocene time, but it undoubtedly came after post-Miocene erosion had begun, and the absence of Pliocene sediments suggests that it was later than the Pliocene epoch.

\section{QUATERNARY TIME.}

Glaciation.-During the Pleistocene epoch there were extensive valley glaciers throughout this portion of Alaska, at least as far to - the southwest as Pavlof Bay. The ice formed among the summits of the Aleutian Range at the heads of well developed valleys, and in the movement of the resulting glaciers toward the Pacific Ocean or toward Bristol Bay the valleys were greatly deepened and broadened. The glaciers made the basin areas high among the mountains much broader, and in many areas left deposits of glacial drift.

The islands-most notably Unga Island-have been greatly modified by ice action, so far as they have been examined. Valleys have been broadened and deepened, foothills reduced in elevation, and lowlands mantled with morainic deposits. The glacial geology of the region is fully discussed on pages 84 to 91 .

Recent geologic history.- Since the retreat of the ice the agents of weathering have renewed the work of disintegration on all uncovered surfaces. Streams have carried the fragmental material resulting from the processes of this disintegration to lower levels, spreading some of it over the bottom lands in the valleys and depositing some at the heads of bays and along the outer coasts. The waves, undertow, and shore currents have cooperated to modify the coast lines. Erosion has been in progress at some places but at other points deposition has predominated. The modern shore-line features, which will be described more fully later, have been developed as a result of these various processes. Since the retreat of the ice the sea has withdrawn from some of the lower lands bordering the coast, so that the former shore line is about 100 feet above the present mean-tide level. Locally volcanic activity has continued.

\section{GEOMORPHOLOGY.}

\section{MEANS OF INTERPRETATION.}

In working out the physical history of a province no sharp line can be drawn between geologic and physiographic studies even for any one region, much less for different regions or for different portions of any large province. The physiographic history of a region comprises

$90054^{\circ}-$ Bull. $467-11-6$ 
only the later chapters of the geologic history; but field observations and field methods of work in physiographic studies may differ somewhat from the observations made and the methods used in working out the earlier geologic history. In physiographic studies special attention is given to the present forms of the land, to the topography, to the relation of topographic forms to geologic structure, and to the different kinds of rocks, and to the broad topographic relations of different land forms. Physiographic study also involves a careful examination of all recent deposits. The unconsolidated sediments may contain in their materials, their forms, and their topographic relations the record of the most recent happenings in that region. When the evolution of the present land forms has been fully worked out the later geologic history of the region has been determined.

\section{EOCENE SEDIMENTATION AND THE GROWTH OF THE ALEUTIAN RANGE.}

The present distribution of the Kenai formation makes it evident that Eocene sedimentation was widespread in the Alaska Peninsula, and it is undoubtedly true that this formation was formerly more widespread and more continuous than it is to-day. The nature of the sediments and the life record in these rocks show that the deposits were made alternately from shallow marine water and from marshes during the early and middle portions of the period. Local volcanoes existed in early Eocene time and toward the close of the period, and numerous centers of active volcanic action were associated with a general orographic movement. Great masses of lava were thrust into, and in some places through, the Eocene sediments; and vast quantities of fragmental materials were scattered over portions of the area.

The volcanic activities of this period were attended by a general deformation of the strata and by the uplift of the Aleutian Range of mountains. Earlier mountain ranges may have existed in this portion of Alaska. Mountains may have been formed during Mesozoic times in the northeast portion of the peninsula, but if these earlier mountains were thus formed, they were probably largely removed by the close of Eocene time. The first and probably the greatest period of growth of the modern Aleutian Mountains came near the close of Eocene or at the beginning of Miocene time. The general outline and major physiographic features of the Alaska Peninsula were then much the same as they are to-day.

\section{MIOCENE EROSION AND POSSIBLE PLANATION.}

The rocks that formed the land surface that was uplifted at the time indicated may not anywhere exist to-day. So far as the region has been examined no portion of that surface has been recognized; 
on the contrary, there is abundant evidence that vast quantities of rock, in some places thousands of feet thick, have been removed. Disintegration began when the land rose above the sea and the winds and streams undertook their work of carrying the loosened material to the sea. Ocean waves attacked the margin of the new land, cutting away the softer and more exposed portions, while the undertow and shore currents shifted the loosened material to favorable sites for deposition. The sediments deposited during this period contain the records of Miocene marine life. These sediments, so far as is known. are limited to small baylike areas at the margins of the peninsula or near the shore of the neighboring islands; indeed, they have been found only in the western part of the peninsula, in the vicinity of Balboa and Herendeen bays and on the islands of the Shumagin group. It appears, therefore, that the northeastern part of the peninsula was somewhat larger during Miocene time than now, and that a large part of the sediments of Miocene age now lie on the sea bottom, perhaps some distance beyond the present margin of the land.

How far this process of erosion succeeded in reducing the land during Miocene time is as yet uncertain. No doubt the land stood much lower, relative to the sea, than it does to-day, for Miocene sediments of marine origin have been found fully 1,000 feet above sea level in nearly horizontal positions. At these localities the summits in the central portion of the range are from 2,000 to 3,000 feet above sea level. There is a striking correspondence of summit levels over large areas of the Aleutian Range (Pl. XI, $B$ ) and it is quite possible that these summits are portions of a deformed peneplain of late Miocene age.

\section{DEFORMATION AT THE CLOSE OF THE MIOCENE.}

At the close of the Miocene there was an orographic movement which brought portions of the sea bottom out of the water and tilted or gently folded the Miocene and all older sediments. The movement at this time was not so great as that at the close of the Eocene. Miocene sediments were elevated at least 1,000 feet, and the main . arch of the Aleutian Range was uplifted. Marginal cross folding probably defined at this time the location of the chief or larger indentations of the coast and the distribution of some of the smaller islands neighboring the peninsula.

\section{PLIOCENE EROSION.}

With the uplift of the lands the streams began working to a new base level. Where new lands rose at the margins. of the peninsula the streams were forced to extend their courses to the new coast line. This period of erosion has continued, except for local interruptions due to volcanism, glaciation, or slight changes in the elevation of 
the land, to the present time. The sculpturing of the main mountain range, begun at the close of the Eocene time and brought possibly to a peneplain stage by the close of Miocene, was renewed. Great valleys were located and were deepened, broadened, and lengthened as time went on. The mountain masses became more sharply defined, and the intervening ridges were left narrower. When the land rose at the close of Miocene time the waves and shore currents began work at a new horizon. Wearing was in progress at some places and building at other points. The main physiographic features were roughly outlined at this time, but their forms have been greatly modified by glaciation and later erosional and deposition work.

\section{GLACIATION.}

\section{GENERAL EFFECTS.}

The Pleistocene glaciation, which is only one chapter in the long history of degradation and aggradation that dates back to the close of Miocene time, has produced the present general form and the details of many of the more important physiographic features in this part of Alaska. In those parts of the peninsula that have been studied in detail there is evidence of glaciation from the crest of the range to the shore lines, both to the northwest and southeast. The glaciers formed among the summits of the Aleutian Range and were guided in their movements by the preglacial erosion lines, the ice forming near the crest of the range advancing down the valleys. The glaciers reached the sea on the Pacific Ocean side and must have yielded vast numbers of icebergs. To the northwest the ice deployed on the lowlands at the base of the mountains and there formed great piedmont glaciers that advanced nearly or quite to the margin of Bering Sea.

Among the summits of the range the work of the ice is recorded in the great amphitheatrical cirques and in the sharpened peaks and divides. The valleys have been changed from the V-shaped depressions characteristic of youthful stream-made canyons to broad open U-shaped troughs. In the northeastern portion of the peninsula the four large lakes-Kukaklek, Naknek, Becharof, and Ugashik-probably owe their present depth and outline, if not their existence, to ice gouging. With the exception of Ugashik Lake, they lie in valley courses leading from the mountain peaks to the shore of Bristol Bay. The longer dimension of Ugashik Lake is approximately parallel to the axis of the peninsula, and it is unlikely that glaciers moved in that direction; but the ice in passing across the basin must have deepened and broadened the area now occupied by the lake. The narrow tongues of ice which filled the well-defined valleys to the sea so excavated those depressions that upon the retreat of the ice the sea invaded the land areas (Pl. VIII, p. 42) in long, narrow bays or fiords. 
Bare rock surfaces on the canyon walls have been polished and striated, and rock surfaces bordering the bays in the lowland areas show the usual marks of glacial wear, such as striæ, grooves, and polishing.

Much of the material gathered by the ice was deposited offshore or carried out to sea by icebergs; but a portion of the material was deposited on the present lands of the peninsula. The glacial drift is most extensive on the lowlands of the northwest side of the peninsula. There the deposits, so far as they have been examined, mantle the lowland area and give to it a topography similar to that of the glaciated portions of the upper Mississippi Valley. The moraines have the characteristic hummocky form, with small knobs and shallow depressions. Water has accumulated in many of the depressions, so that this portion of the peninsula has numerous small lakes and many swamps or marshes which record the former existence of lakes or ponds. In the mountain valleys the ice succeeded in removing most of the loose material and in carrying it to the sea; but on the retreat of the glaciers small areas of drift were left, as lateral moraines, medial moraines, or in a thin scattering of bowlders. The glacial geology of those portions of the peninsula that have been studied in detail will be given below.

\section{GLACIATION OF UNGA ISLAND.}

The island of Unga was almost completely covered by glacial ice during the Pleistocene epoch. This ice formed in the catchment areas among the higher peaks of the central portion of the island and moved seaward, guided in its direction during the earlier stages of its movement by the main drainage lines of the island. As the snows became thicker and the quantity of ice proportionately larger, it appears from the distribution of glacial deposits and markings that the ice covered all but the higher peaks and moved in a somewhat radial way from the central portion of the island.

The glacial drift consists of intermingled bowlders and fine materials that have been deposited without having been assorted. The distribution of these deposits is indicated on Plate VIII (p. 42). Very little glacial débris occurs in the higher portions of the island, for the ice as it moved out from the central portion of the island swept along with it all the available loose material and did some wearing and smoothing of the rock surfaces. In the main valley west of Unga Harbor where the Apollo and Sitka mines are located there are considerable quantities of glacial drift, part of which is left on the valley walls as lateral moraines and part of which is deposited on the valley bottom as ground moraines. At the head of Coal Harbor are ocher patches of glacial drift of sufficient extent to be shown on the map. In the west central portion of the island there is a considerable quantity of glacial drift of characteristic rolling topography in 
which are several undrained depressions containing water. A ridge capped throughout the greater portion of its length with glacial drift extends about 5 miles in a general westerly direction in this portion of the island. The location and form of this deposit indicate that the ice which formed it moved in a general westerly direction from the center of the mountain district and that the surface of the ice must have been only a few hundred feet below the summits of the highest peaks in the island. Numerous minor deposits of glacial drift, of too slight extent to be mapped but of sufficient extent to block drainage and to form numerous small lakes and ponds, occur in the southwest part of the island. The northwest and northeast peninsulas of the island are lowlands, over which is distributed a mantle of glacial drift in places at least 40 feet thick. This drift deposit has the characteristic rolling topography of moraine on lowland areas and is dotted among the hills or mounds with numerous depressions which serve as the beds of small lakes. These depressions are much more numerous than the topographic map indicates. The location and distribution of these deposits, which extend nearly or quite to the modern seashore across lowland areas, show that during the stage of maximum glaciation there was a small ice cap on this island.

The erosional work of the ice has modified the summit region by broadening and deepening the great catchment areas or cirques, the larger valleys, and, presumably, the inlets or bays which now indent the coast of the island. The bays have probably been lengthened as well. Thus the harbor at Unga (Pl. XI, $A$, p. 86) owes its origin, in part at least, to the gouging by the ice which moved along its course and presumably ended as the "live glaciers" of southeastern Alaska end to-day. Baralof, or Squaw Harbor, the inlet next north from the village of Unga, was also deepened, widened, and lengthened by ice action. The great U-shaped troughs at the head of this inlet contained ice more than 1,000 feet thick. The streams of ice from these troughs united near the head of the present harbor, moved eastward through the harbor trough, and must have ended as a live glacier near the present harbor entrance. Coal Harbor probably contained a very considerable glacier. The great troughs at the head of this inlet contained glaciers at least 1,000 feet thick that probably advanced nearly as far north as the island extends. The small island in the midst of Coal Harbor is so rounded as to suggest that the ice passed over and about it during the glacial period.

The evidence of the erosional work of the ice includes all those features common to mountainous regions that have been glaciated and, also, in the modifications of the coast, the deepening of fiord-like inlets such as characterize most glaciated rocky coasts. 


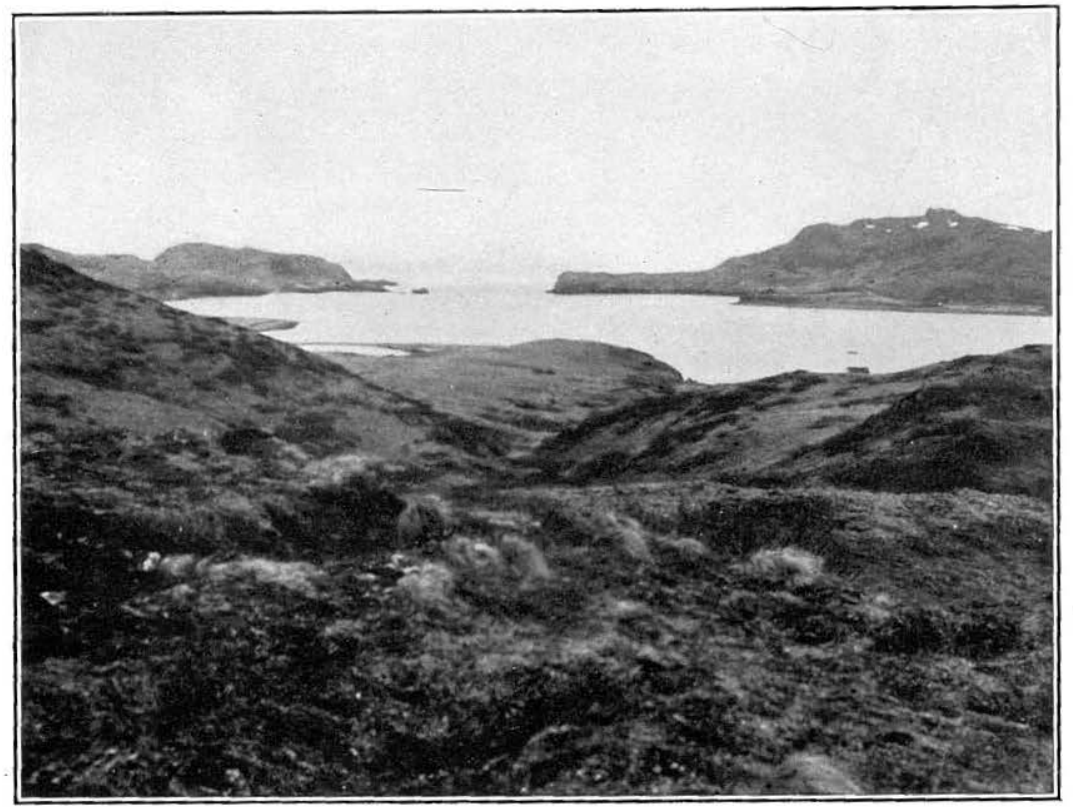

A. UNGA HARBOR FROM THE WEST.

See page 86.

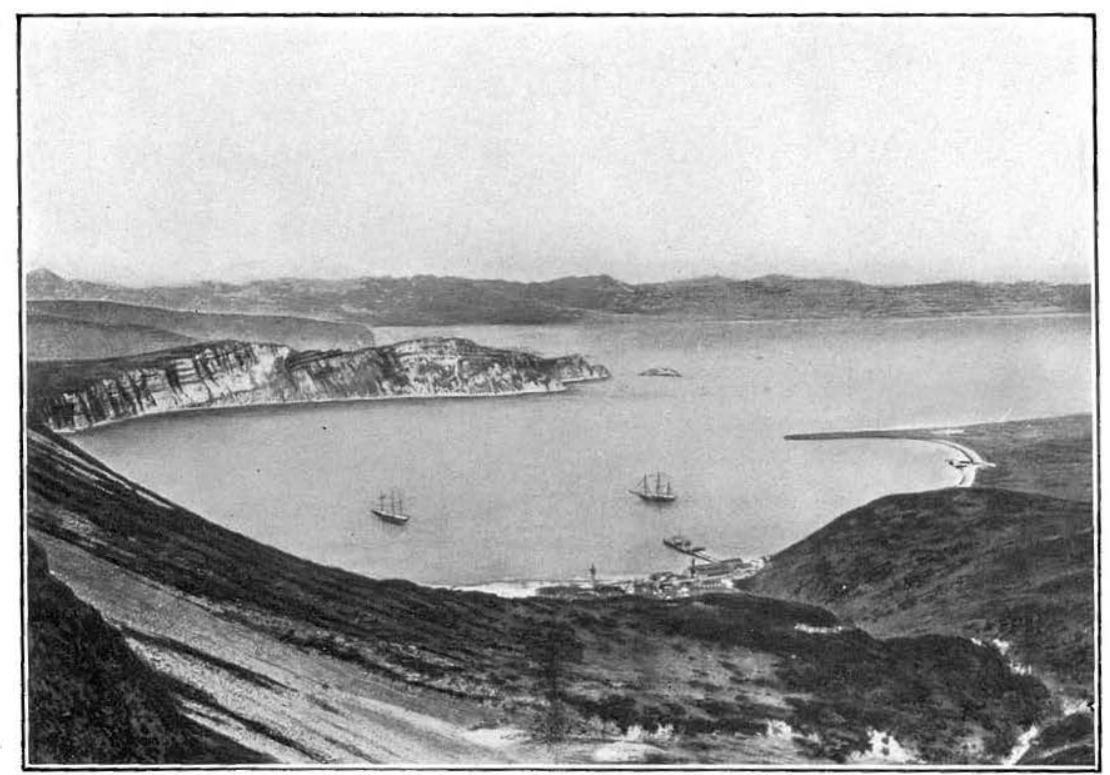

B. ANCHORAGE BAY FROM THE SOUTHWEST.

Beyond the larger body of water, which is a portion of Chignik Bay, are the Aleutian Mountains. The correspondence of summit levels is somewhat remarkable. See pages $75,83,90,108$. 

The glacial drift of Unga Island varies greatly in its composition from place to place. Examination of the geologic map (Pl. VIII, p. 42) will explain the differences in the constitution of the drift, for the variety of igneous and sedimentary rocks that outcrop in the island readily accounts for the variety of stones found in the drift. Most of the stones in the material of the glacial deposits are less than a foot in diameter. The fine material consists of coarse sands and gravels derived from disintegration of crystalline rocks or from wearing of sedimentary formations, and of clay originating in the most thoroughly decomposed portions of the igneous rocks, or in the partially consolidated Tertiary beds. The actual amount of glacial drift in the mountainous portion of the island is very small, a condition consistent with these in many other mountainous areas that have been glaciated. The ice cap of Unga and the distinct valley glaciers that characterized the early and late stages of glaciation in the island must have carried vast quantities of débris to the sea.

The present valleys are the upper portions of the former glacier courses, and in these upper courses deposition is not usually conspicuous. Alpine glaciers commonly scour out the heads of the valleys and carry the loose material gathered in the process to the maximum position of the ice advance. Here the glacial material was carried to the sea and distributed by the waves, currents, and icebergs over the sea bottom.

No evidence of distinct glacial epochs was seen in this island or, indeed, in any of the places studied in southwestern Alaska. The ice presumably left the higher mountainous area much later than it left certain of the lower or southern mountain ranges in the Western States or the areas occupied by the continental ice sheet.

GLACIATION OF POPOF ISLAND.

Popof Island is just east of Unga Island. A sufficient mantle of glacial drift remains in the northwestern corner, the part visited by the writer, to indicate that ice probably covered the greater.part of the island during the Pleistocene epoch. Small lakes and ponds are not uncommon in the island, and the depressions in which they lie are probably due to the irregular distribution of morainic material.

\section{GLACIATION OF THE BALBOA-HERENDEEN BAY DISTRICT.}

Much of this portion of the Alaska Peninsula was covered by ice during the Pleistocene epoch and the glaciers presumably did not leave the higher mountain areas until long after the ice had left the interior of the continent. Evidences of glaciation in this region appear in the great cirques or catchment areas, the broad, open, U-shaped canyons, the fiords, or bay-like inlets, the smooth, striated, 
and polished surfaces of bed rock, and the characteristic glacial deposits, which are somewhat widely though irregularly distributed in the region.

The ice formed among the summits of the Aleutian Mountains and in its movements was directed by the drainage lines which existed in preglacial time. Those drainage lines were deepened and broadened; the present $U$-shaped form of the valleys is interpreted as of clacial origin, and the amphitheatral catchment basins at the heads of the canyons owe their present form chiefly to ice action. The higher summits may have risen as nunataks above the ice during the maximum extent of glaciation. The passes and all the great valleys were occupied by the glaciers, and the lowland areas, wherever they have been examined, were formerly overridden by ice. This region, during the glacial period, was, presumably, a great arch of snow and ice, extending to tidal waters on either side of the peninsula. Above the snows of the catchment area a few dark specks may have appeared where the higher peaks protruded above the white mantle. The glaciation was not of a mild form. The catchment areas show signs of intense ice action, and the broad, open, U-shaped troughs are evidence of vigorous erosion by the ice. The indented coast line of this portion of the peninsula is accounted for in part, at least, by the intense glaciation which has affected the region. It is fair to assume that the bays and various inlets were depressions, presumably drainage lines, in preglacial time, but their present extent and outlines were notably changed by the glaciers. The markings on the polished and striated rock surfaces that occur at various places within this area indicate the direction of ice movement at each place. The striæ are in general parallel to the stream courses and indicate that the movement of the ice was controlled by the preglacial topography. Striated surfaces a few feet above sea level on the shores of Balboa Bay make it evident that the ice occupied at least the head of that inlet and that the action near the coast was vigorous.

- The glacial deposits consist of irregular patches of morainic material lodged on the valley slopes as lateral moraines or at the junctions of valleys as medial moraines. Some of the patches mapped cover the lowlands or floors of the valleys and should perhaps be classed as ground moraines. The valley walls are commonly too steep to have allowed the lodgment of any considerable quantities of drift on them, and the only areas in this district where drift deposits are extensive are near the head of Port Moller, in the vicinity of Point Divide, and on the islands still farther northwest. (See Pl. VIII, p. 42.)

The drift deposits about 1 mile west from the head of Balboa Bay are distributed as lateral and medial moraines. These deposits appear as ridges 20 to 50 feet-high on the lower slopes of the valley, and as slightly larger forms where two lateral moraines have joined 
to form a medial moraine. The surfaces of the morainic ridges are strewn with bowlders, and the exposed sections exhibit the structureless nature of the deposit. Most of the stones are subangular and many of them are striated.

The glacial drift near Point Divide and at the head of Port Moller forms a mantle on the lowlands and gives to the surface a gently rolling topography characteristic of ground moraines. Exposures in the drift may be seen along the shores of the bay and in some of the stream cuttings, and in these exposures the material has the characteristic physical and lithologic heterogeneity of glacial deposits. The surface of the moraine is clothed with a thick tundra growth which obscures the rock material and softens the contour of the drift hills.

The most extensive glacial drift deposits in the Balboa-Herendeen Bay region cover the lowland area extending from the base of the mountains northwest to the modern beach deposits of the Bering Sea shore. Exposures along the beach near Point Divide show that this drift mantle is at least 40 feet thick in places. The material in this part of the Alaska Peninsula resembles the glacial débris already described, and its topography is not unlike that of other lowland areas that have been covered by drift. The surface of the moraine is characterized by undrained depressions and low hills, which gives the land a gently rolling topography. In many of the undrained depressions there are ponds or small lakes.

The nearer of the low islands beyond the mainland of the peninsula are known to be mantled with glacial drift. These islands rise 30 or 40 feet above the water. The outer islands, which were seen only from a distance, may be composed in part of glacial material, but as the lands have risen at least 100 feet since the retreat of the glaciers the outer islands are probably mantled with recent shore line alluvium. White residents of this coast report extensive sand dune areas along the outer beach.

The glacial deposits near the head of Herendeen Bay are lodged in places unfavorable for removal by erosion. They cover small areas in the lower portions of glaciated valleys and appear in form and in topographic relations to be only remnants of lateral or medial moraines.

The drift in this region consists of unstratified bowlder clays. The stones differ greatly in different places, and include a wide range of sedimentary formations, together with a considerable amount of igneous material. The sizes of the stones range up to at least 6 feet in diameter. The variety of this material is readily accounted for by the distribution of the many varieties of rock formations within the area. 
No evidence of distinct glacial epochs is found in this region. The ice of the most recent epoch, if, indeed, earlier glaciers ever occupied these valleys, apparently moved down the main valleys beyond the present shore lines and obliterated the record of the former occupancy.

\section{GLACIATION OF THE CHIGNIK BAY REGION.}

In the Chignik Bay region of the Alaska Peninsula, the central and higher peaks reach elevations between 2,000 and 3,000 feet. The snows lodged and ice formed in the large catchment areas among the summits during the glacial period, and from these basins the ice moved in a general way southeast toward the Pacific Ocean, and northwest toward Bering Sea. Movement of the glaciers while the ice accumulated and during the earlier stages of glaciation was controlled by the location of the main drainage lines of the region. Later the ice became more extensive and overrode many of the inter-valley areas. The northwest base of the mountains was not seen in this district, but records left by piedmont glaciers may be anticipated for that region.

The cleaned-out condition in the basin region indicates very vigorous ice action, and the scarcity of loose material of postglacial origin may mean that the ice has but recently left these mountains. The large valleys leading away from the catchment areas are broad, open, U-shaped troughs. The chain of lakes crossing the peninsula from the head of Chignik Lagoon appears to owe its origin partly to ice gouging and partly to the deposition of glacial débris. The head of Chignik Bay and the whole of Chignik Lagoon, Anchorage Bay (Pl. XI, $B$, p. 86), Mud Bay, and the various inlets south of Castle Cape were undoubtedly deepened and broadened by ice action. Hook Bay, farther north, was in part formed by the action of glacier ice.

Deposition by the glaciers was chiefly on the lowlands bordering the Pacific and Bering Sea sides. Descriptions given by travelers to the writer indicate that the lowlands northwest of the mountain range must be mantled by glacial drift. The lowlands in the immediate vicinity of Chignik Bay contain irregular patches of glacial drift, as do also the hillsides, where the slope is not too steep to prevent the lodgment of drift.

Glacial drift has been indicated on the geologic map (Pl. VII, p. 40) where such material mantles and obscures the underlying formations. Two small areas of morainic deposits shown on the map near the lower end of Chignik Lake lie in the course of a former glacier that must have moved eastward from the mountains west of Chignik Lake through the lake basin, down the Chignik River valley into Chignik Lagoon, and possibly into Chignik Bay. Scattered 
remnants of the morainic deposits of this glacier were seen at several points, but in only a few areas were the deposits of sufficient extent to be properly represented unless a larger scale map was prepared. Along the shores of Chignik Lagoon there are, at a few points, good exposures in morainic deposits. Large and small bowlders are intermingled with clays, sands, and gravels. The material is unstratified, and appears to be just as it was deposited by the melting of the ice. Many of the larger stones are subangular in form and their surfaces are not uncommonly striated. The larger area of moraine covered country south of Chignik Lagoon and near the low pass to the head of Kuiukta Bay has a glacial topography modified but slightly by post glacial stream erosion. The scattered patches of glacial drift near the northwest shore of Chignik Bay are regarded as mere remnants of moraines that probably mantled much of this piedmont area.

As yet no indications of distinct glacial epochs in the Chignik Bay region have been seen. The ice of the Recent glacial epoch appears to have advanced on the Pacific Ocean side to tide waters, and such ice would in all probability have removed all evidence of any previous glacial epoch.

\section{RETREAT OF THE ICE.}

When the climate became warmer, less snow was precipitated and the glaciers began to retreat. There was no backward movement, but the melting was in excess of the onward movement, and accordingly the margin of the ice came to be farther and farther from the shore. The last remnants of the glaciers were therefore in the basins where the first ice formed. The glaciers still remaining in the northeastern portion of the peninsula are the shrunken remnants of the ice that occupied the great valleys in that region during the Pleistocene epoch.

As the ice retreated streams issued from beneath the ice and distributed down the valleys from the margins of the glaciers vast quantities of sands, gravels, and clays, and partly refilled the troughs that the glaciers had deepened. At this time the lands stood at least 100 feet lower than they do to-day, and much of the material deposited by the ice or washed from beneath the glaciers by streams was deposited in water. As the ice tongues became shorter the fiords became longer, and when at last the ice had left the lower portions of the valleys and retreated to the catchment basins waterways reached well into the central portion of the peninsula. In the Chignik Bay region there must have been a continuous water route from the Pacific Ocean to Bering Sea. 


\section{POST-PLEISTOCENE EROSION.}

Since the close of Pleistocene time the lands have been subject to the work of streams and to all those processes tending toward the disintegration of rocks and to their removal to the sea. Winds, rains, "changes in temperature, and frost action have been loosening and comminuting all rocks exposed to the atmosphere. Water beneath the surface has assisted in weakening the rocks by taking up their soluble salts, and has thus indirectly hastened their journey to the sea. Erosional wind work is not very noticeable, but depositional work by the winds has built up numerous small dunes at various places on Unga Island and on the mainland to the north. Dune forms will undoubtedly be found at various places along the Bristol Bay side of the peninsula.

Some talus has accumulated among the higher peaks in the general degradation of the lands, and where conditions were favorable landslides have taken place. Several considerable areas owe their topography to landslide blocks or masses that have moved from some bordering cliff.

The glaciers at the northeast are active agents of erosion, for they are undoubtedly lowering the valley bottoms over which they move, broadening and deepening the basins near the summits, and grinding much of the material carried near the base of the ice into finer and finer particles. This northeastern part of the peninsula is now undergoing a glacial period.

Streams have renewed their work of wearing and of carrying loose material to the sea. Some rivers are still engaged in removing the glacial débris left in their courses; other rivers, that have had little morainic material to handle, have cut narrow gorges in the rock at the bottoms of the canyons. At the heads of all of the larger bays the waste brought down by the streams has helped to extend the lands. Deltas have been built out into the bays, and are still in the process of growth.

\section{MODERN SHORE LINES.}

The Pacific Ocean side of the Alaska Peninsula presents a bold, rugged coast, bordered at many points by steep cliffs, and indented by fiordlike inlets separated from each other by headlands of most rugged and fantastic features. The smaller islands bordering the coast appear in places to be continuations of the headlands, separated from them by wave erosion. The larger islands, notably the Shumagin group and the Sannak Islands, are chiefly of volcanic origin and appear to have been throughout their history distinct from the mainland of the peninsula. The shore line features include sea cliffs; overhanging ledges, arch rocks, sea caves, rock pillars, balanced rocks (Pls. V, p. 38 ; IX, $B$, p. 62 ; and XII) and, at the heads of 


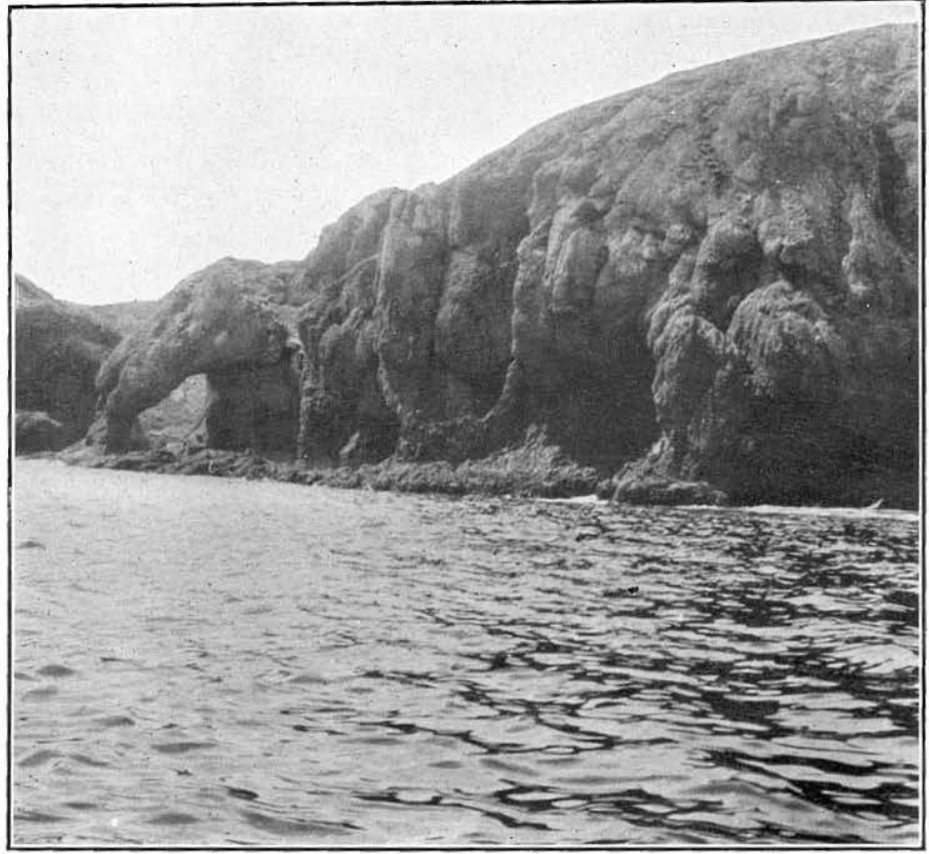

A. SEA CAVES AND AN ARCH ROCK ALONG EAST COAST OF UNGA ISLAND. See page 92.

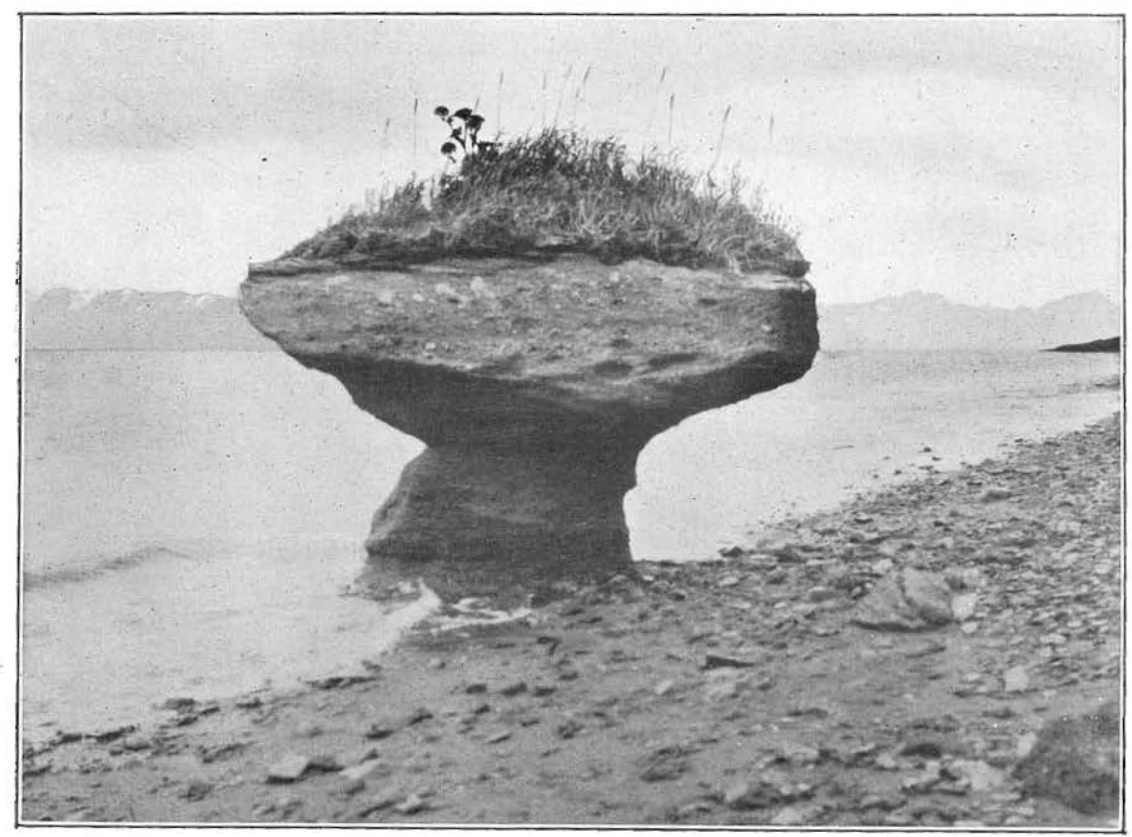

$B$. SHORE LINE PILLAR OF CONGLOMERATE.

This has been separated from a neighboring cliff by wave erosion. See page 92 . 

many bays and inlets, sand bars, hooks, spits, barrier beaches, land-tied isländs (Pls. IV, $B$, p. 12 ; XIII, $A$, p. 108; figs. 11; 12; 16, p. 107; and 18, p. 129) or bayhead deltas. The activities along the Pacific coast appear to be chiefly those of erosion, and amount of shore line deposition is almost insignificant.

The larger features of the coast, the bold headlands, the bays, and the fiords, are explained in part.by glacial gouging and in part by recent sinking of the land. The sea cliffs, overhanging ledges, arch rocks, sea caves, and rock pillars are due to the erosional work of the waves, which are active along a zone that extends a little below sea level and a little above sea level. Rock material is loosened and broken along that horizontal zone, and the resulting fragmental material is carried away by the undertow and currents. Undermining results and sea caves with overhanging ledges of rock come into existence. In narrow pro $^{-}$ jecting points sea caves may so develop that arch rocks are left. In time increased undercutting causes the overhanging rock to fall, and the sea cliff retreats. When such work is progressing rapidly, the shore line features are rugged and signs of active change are abundant. The sea terraces referred to on the

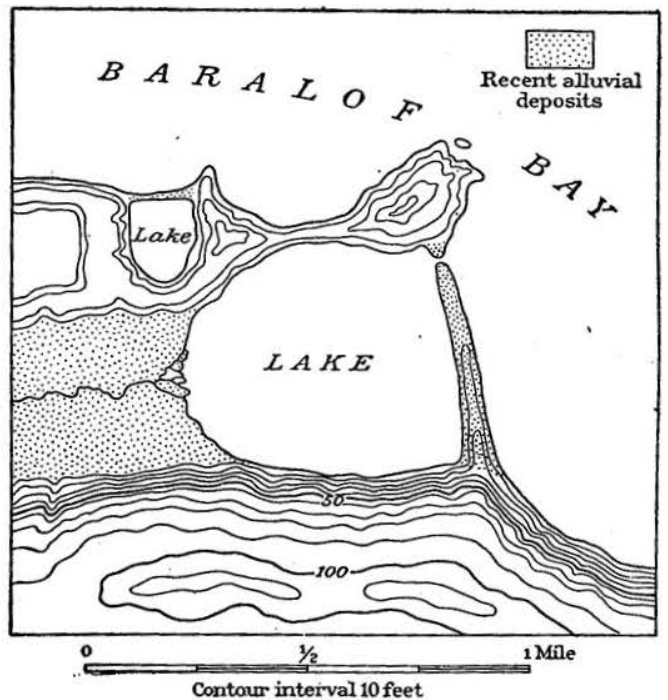

FIGURE 11.-Sketch map of shore features near south entrance to Baralof Harbor, Unga Island.

mainland coast and near the margin of Unga Island ( $\mathrm{Pl} . \mathrm{X}, A, \mathrm{p}$. 70) record wave work when the sea stood higher relative to the land areas. Such terraces may not have been developed all along the coast, or they may have been destroyed by subsequent wave action at many places where they formerly existed.

The lands are low and the waters shallow along the Bristol Bay margin of the peninsula. The waves strike the bottom long before they reach the coast, and instead of doing much erosional work. they are chiefly active in the deposition of beach materials. Low sea cliffs are reported near the head of Bristol Bay, but southwest of that point sand and gravel beaches, sand reefs, small islands, and offshore bars characterize the coast. The waves, undertow, and shore line currents are engaged in shifting the loose materials 
from place to place. The few large bays on this side are due in part to sinking and in part to ice gouging, as were the main inlets on the Pacific Ocean side.

\section{RECENT CHANGES IN LEVEL.}

The configuration of the coast line of the peninsula indicates that in relatively recent geologic time this land area has been somewhat depressed. The great bays and fiords do not appear to be due entirely to glacial erosion, nor can all the islands that continue seaward from the headlands be explained by glacial erosion or shoreline activities. A slight depression of the land would account most

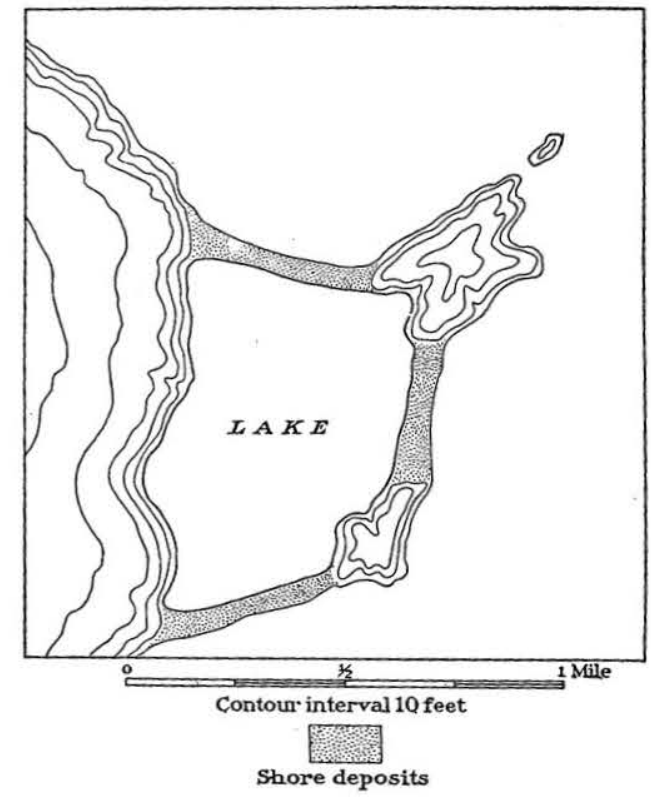

FIGURE 12.-Sketch map of shore features near north entrance to Baralof Harbor, Unga Island. simply for these features. The sea terraces that now lie 100 feet above the mean tide level, and the alluvial flats that extend upstream to an elevation of about 100 feet in the larger valleys indicate that the lands recently stood somewhat lower and have since been uplifted. The amount of uplift has not been equal to the amount of depression, and as a consequence the coasts still retain features due- to partial drowning. Whether this depression came a little before, contemporaneous with, or a little after, glaciation can not be positively asserted.

The sea terraces, however, contain some worked-over glacial drift upon their surfaces that may have been deposited offshore during the period of maximum glaciation or later. The alluvial deposits which extend far into the peninsula (Pls. VI, in pocket; VII, p. 40; and VIII, p. 42) suggest the former existence of long bays, many of which were bordered by high mountains and must have been like the present fiords of Norway and Sweden. Since the retreat of the ice and the more recent uplift of the land which brought the sea terraces and the upper portions of the fiords above water, erosion by streams, waves, and shore-line currents has been renewed at a new horizon. The streams have taken up the work, left by the glaciers, - of carrying the materials of the land to the sea; 
the waves are actually engaged in modifying the coast; the winds are assisting in redistributing loose material; and the agents of weathering are doing their part in the general disintegration of exposed rocks.

\section{SUMMARY OF LATE GEOLOGIC HISTORY.}

Toward the close of Eocene time an orographic movement disturbed Alaska Peninsula and defined the present chain of the Aleutian Range. Erosion began with the growth of the mountain, and continued through Miocene time. While erosion was in progress on the land, Miocene sediments were being deposited about the shores, so that during the period of erosion, the mountain area was reduced to a land of much less relief than the present, and perhaps to a peneplain. At the close of Miocene time a renewal of mountain growth brought about a rejuvenation of the streams and opened a new cycle of erosion, which continued during the Pliocene epoch. By the opening of the Pleistocene epoch the valleys thus eroded probably reached nearly to the crest line of the range. Ice formed among the summits and advanced on either side of the peninsula to sea level. The land probably stood higher during the Pliocene epoch than it does at present, but during Pleistocene time it appears to have been somewhat lower than it is to-day. A slight upward movement of the land and a renewal of stream erosion followed the retreat of the ice and the disappearance of glaciers from the greater part of the peninsula. The coast which now presents so many remarkably interesting features has been profoundly affected by each period of mountain growth, by glaciation, and by recent changes in the level of the land relative to sea level.

\section{MINERAL RESOURCES.}

\section{DISTRIBUTION OF KNOWN MINERAI RESOURCES.}

The known mineral wealth of southwestern Alaska consists of coal, petroleum, gold, and copper. The general distribution of these deposits is shown or Plate VI. The important coal fields are near Chignik Bay and near Herendeen Bay. Less important deposits of coal and lignite have been found in Unga Island and at a few places in Alaska Peninsula. Near Amalik Harbor Dall ${ }^{1}$ noted an 18-inch bed occurring in a sandstone and conglomerate series 250 feet thick. Stone ${ }^{2}$ described a section at this same locality made up of sandstones and fine conglomerates, with some shales, in which occurs a 5-foot bed of coal, and made reference also to less well-authenticated accounts $^{3}$ of the occurrence of coal-at Ugashik Lake and Aniakchak Bay.

1 Dall, W. H., Coal and lignite of Alaska: Seventeenth Ann. Rept. U. S. Geol. Survey, pt. 1, 1896, p. 798.

2 Stone, R. W., Coal in southwestern Alaska: Bull. U. S. Geol. Survey No. 259, 1905, p. 161.

Idem, pp. 162-163. 
The first coal mining undertaken by Americans in this portion of Alaska was begun in 1882 at Coal Harbor. Previous to that time the Russians had taken out some coal from the same field. Work was begun on the coal at Herendeen Bay in 1880, but no shipments were made until 1890. Coal was discovered on Chignik River in 1885, and mining began at that locality in 1893 .

The oil seepages occur in the vicinity of Cold Bay. Placer gold has been found in paying quantities in the beach at the west margin of Popof Island just south of Sand Point. Several locations for gold have been made on Popof Island, and lode mining was conducted successfully on Unga Island from 1891 to 1904.

On the west shore of Prospect Bay, a small reentrant a few miles west of Chignik Bay, there are evidences of copper, and on the east shore of Balboa Bay there is an abandoned copper prospect.

COAL.

HERENDEEN BAY COAL FIELD.

GEOGRAPHY.

Herendeen Bay, the western arm of Port Moller, is on the northwest side of the Alaska Peninsula at about $160^{\circ}$ west longitude and $55^{\circ} 30^{\prime}$ north latitude. (See Pl. VI, in pocket.) The head of the bay is near the central portion of the peninsula, and is only 8 miles from the head of Balboa Bay, a reentrant on the Pacific side. The portage from one of these bays to the other is made by an excellent trail over a pass not more than 500 feet above sea level, which connects two broad, flat-bottomed valleys.

Gently rounded hills and low mountains make up the topography of the coal field (Pl. II, p. 12). The highest points are a little over 2,400 feet in altitude, but the portions above 2,000 feet constitute but a small part of the area. The largest valley is that of Coal Creek, which is located in the central portion of the field. This valley is a broad, open, flat-bottomed trough leading northward through the coal field and westward to Herendeen Bay. The small valleys drain westward into Herendeen Bay and eastward into Port Moller. They are somewhat rugged, and travel is easier on the inter-valley ridges than through the gorges.

The mean temperature is about $46^{\circ} \mathrm{F}$. in the summer season from June to October. During the winter months, from October to May, the mean monthly temperature ranges from $13^{\circ} \mathrm{F}$. to $39^{\circ} \mathrm{F}$. The annual precipitation during 1903 , when records were kept at the Herendeen Bay mine camp, was 46.22 inches. In the summer the number of clear days ranges from 5 to 10 a month. During the 3 years from 1902 to 1904, inclusive, there were 27 days when the minimum temperature was below zero and 4 days when the maximum tem- 
perature was below zero. Mine Harbor was frozen in the years from 1902 to 1906, inclusive, during the following periods: December 18, 1902, to May 6, 1903; December 29, 1903, to May 26, 1904; January 3, 1905, to May 25, 1905; January 15, 1906, to March 17, 1906.

In 1908 Herendeen Bay could be reached by way of Bering Sea by private means of transportation from Unalaska or Nushagak. The more common route is by regular steamer to Balboa Bay, and thence by trail across the peninsula to the head of Herendeen Bay.

The development work that has been done in this field was described earlier in this report (pp. 19-20).

\section{AREAL EXTENT.}

The coal which has been opened and is now being developed is found in a small peninsula between Herendeen Bay and the main or eastern arm of Port Moller. (See Pl. VIII, p. 42.) Coal is exposed at various localities within that area, and coal-bearing formations occupy at least 40 square miles. Some beds of lignite that outcrop on the western shore of Herendeen Bay are reported to extend several miles to the west. Other beds of lignite outcrop in the mountain slopes east of the trail to Balboa Bay, in the central portion of the Alaska Peninsula. The areal extent of the lignite-bearing beds is several hundred square miles, but the known extent of lignite seams that may ever prove to be of economic importance is something less than 10 square miles.

$$
\text { GEOLOGY. }
$$

$$
\text { STRATIGRAPHY. }
$$

The bituminous coal in the Herendeen Bay field occurs only in the Chignik formation. This formation is of Upper Cretaceous age. It rests upon

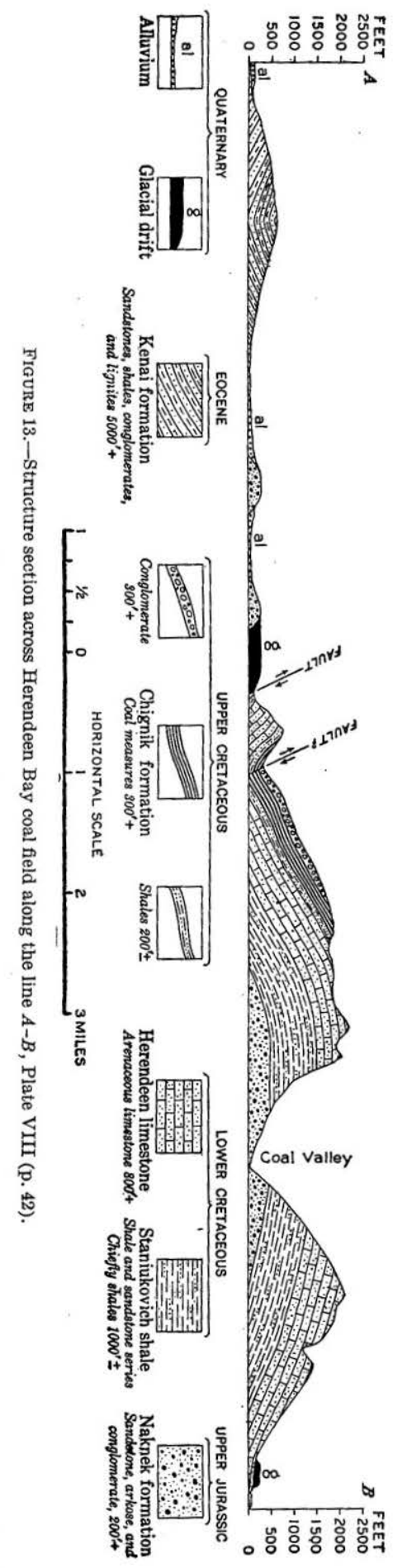




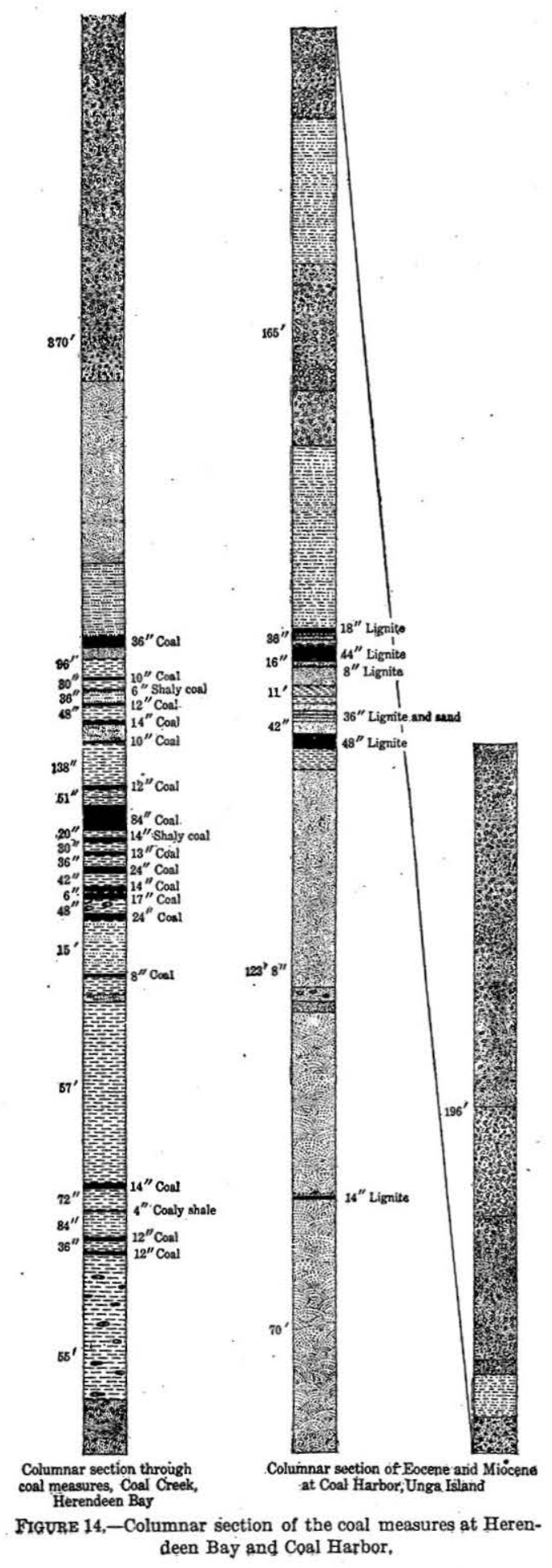

Lower Cretaceous rocks, and is overlain by Eocene beds (figs. 13 and 14). A great faunal break is indicated by the paleontologic material obtained from the Lower Cretaceous and Upper Cretaceous rocks of this region, and unconformity may exist at the base of the Chignik formation. Such unconformity is not apparent within the coal field, however. The relationship of the Eocene (Kenai formation) to the Chignik formation is that of conformity.

The lignite-bearing beds of this field are of Eocene age, and belong to the Kenai formation. They rest conformably upon the Chignik formation (Upper Cretaceous), and in the vicinity of the coal field are related by unconformity to the Miocene beds.

STRUCTURE.

The coal field is located in the minor folds northwest of the main anticlinal arch of the Alaska Peninsula. The sedimentary formations exposed range in age from Upper Jurassic through Lower and Upper Cretaceous to Miocene. (See Pl. VIII, p. 42.) Pleistocene deposits mantle a small part of the area, and in the valley bottoms and along the shores there are alluvial deposits of post-Pleistocene age. 
In the western part of the field, where the coal locations have been made, the formations have not been modified by volcanic intrusions or extrusions, but at the eastern margin of the field dikes vast quantities of volcanic tuffs, and extensive lava flows are numerous. Four volcanic centers, from which lava flows and fragmental
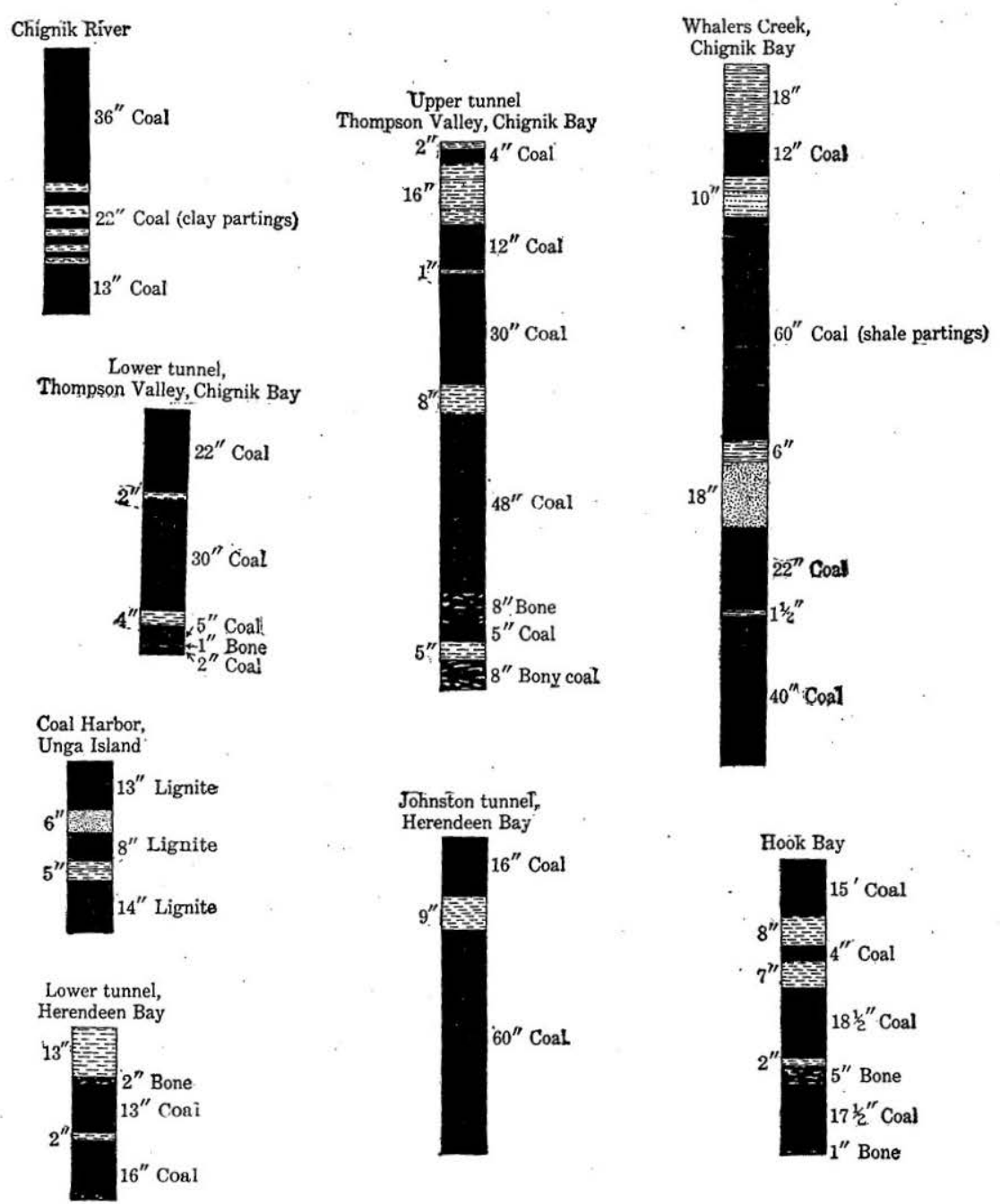

Fisun: 15.-Sections of coal seams in the Chignik Bay and Herendeen Bay fields and at Coal Harbor.

material issued, are situated near the eastern margin of the field. At the northern margin and along Herendeen Bay there are volcanic tuffs, but they are not so associated with the coal as to be significant. The northwestern portion of the small peninsula in which the coal is located is mantled in part by glacial material and in part by recent alluvium, 
The central part of the field has a synclinal structure, with the axis plunging westward. North of this fold there is a broad anticline. Several small faults were noted within the coal field, and one fault contact at the southern margin indicates a throw of no less than 1,000 feet. These faults may be detected by the shifted outcrops exposed in the higher portions of the field, where there is little or no vegetation. Numerous minor faults, of the same general nature as the major faults shown on the surface, may be detected in the mine tunnels. The general structural conditions along a nearly north-south line through the coal field are shown in figure 13, and a general description of the geologic structure of this portion of the peninsula is given on pages 27 to 38 .

THE COAL MEASURES.

The best-known outcrops in the coal field are near the head of Coal Valley and in the valley of Mine Creek. Coal is also exposed near the head of the next valley east of Coal Valley and at several places about the margin of the volcanic tuffs a little farther east, while still other outcrops have been reported in tributaries to Lawrence Creek. The main coal measures outcrop on the east shore of Herendeen Bay, about 5 miles north of Mine Harbor, in a locality known as Coal Bluff. Two beds of lignite have been found on the north coast of the coal-bearing peninsula, about 9 miles east of Point Divide, and several other seams of lignite are exposed on the west shore of Herendeen Bay, nearly opposite Coal Bluff. Columnar sections of these coals are given in figure 15.

The following section in the coal measures was obtained on the south slope of the Mine Creek valley:

Section in coal measures, Mine Creek valley, Herendeen Bay..

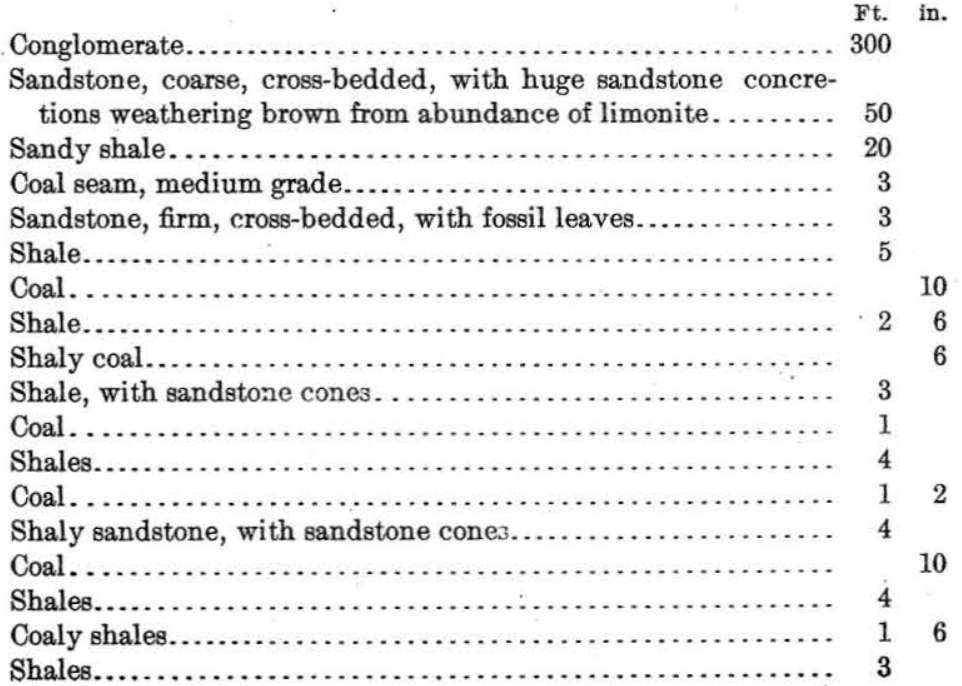


Carbonaceous shales........................ ${ }_{1}^{\text {Ft. }}$

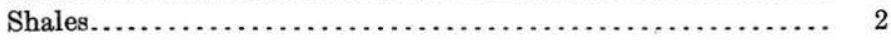

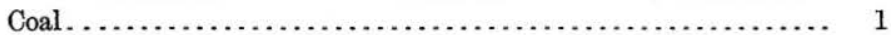

Shales. . . . . . . . . . . . . . 2

Coaly shales, with shale partings...................... $2 \quad 3$

Coal, with bony partings and shaly bed.............. 7

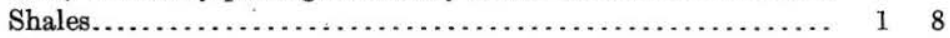

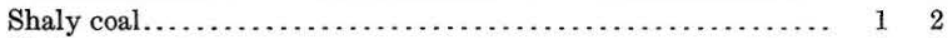

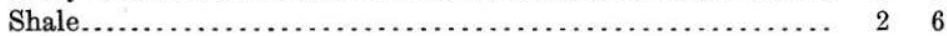

Coal . . . . . . . . . . . . 1

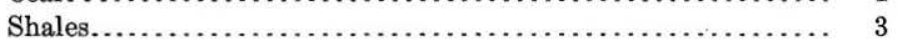

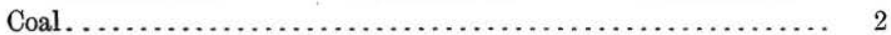

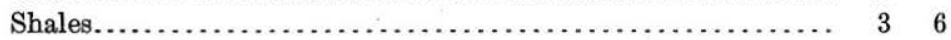

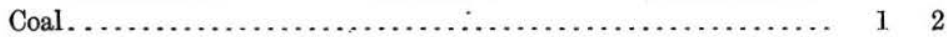

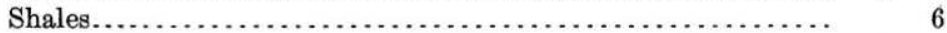

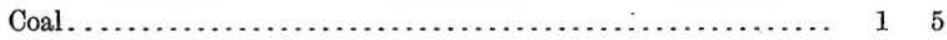

Shales, with sandstone cones........................ 4

Coal. .......................................... 18

Shales and sandstone interbedded................ 15

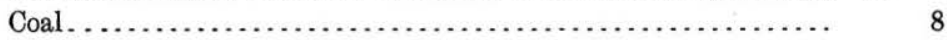

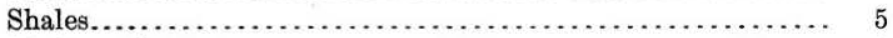

Shaly sandstone. . . . . . . . . .

Shales......................................... 50

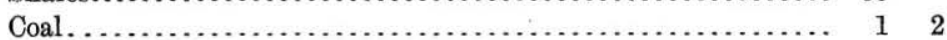

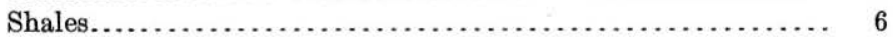

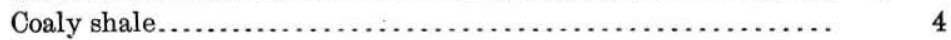

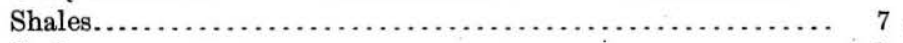

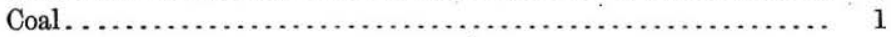

Shales....................................... 3

Coal. ......................................... 1

Shales, with sandstone cones. . . . . . . . . . . . . . . . . . 40

Coarse cross-bedded sandstone and conglomerates........... 15

Shales and sandstones.

The dip of these measures is $30^{\circ} \mathrm{N}$., and the strike N. $91^{\circ} \mathrm{E}$.

On the left fork of Mine Creek Paige ${ }^{1}$ measured the following section:

Section of coal beds on left fork of Mine Creek.

Coal, crushed................................... 7

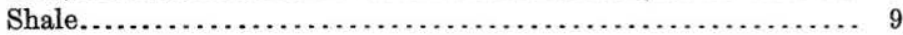

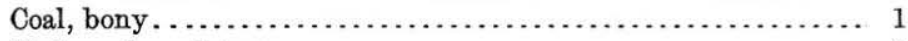

Shale and sandstone.................................. 6

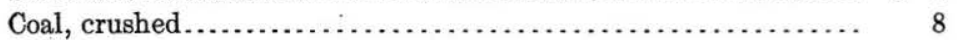

Coal, fairly solid (partly obscured by slide) . . . . . . . . . . 10

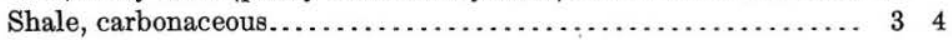

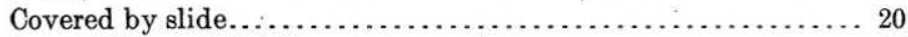

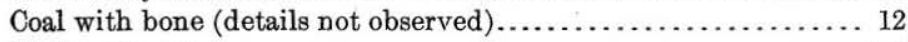

Shale and coal..................................... 4

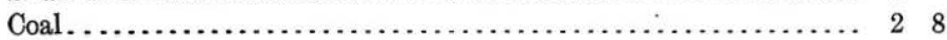

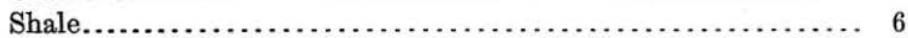

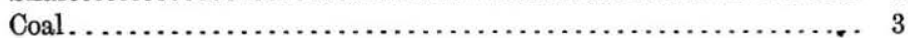

Remainder hidden by slide.

1 Paige, Sidney, The Herendeen Bay coal field: Bull. O. S. Geol. Survey No. 284, 1906, p. 107. 
The detailed section of the coal exposed in the lower tunnel on Mine Creek is as follows:

Section of lower tunnel coal bed, Mine Creek, Herendeen Bay.

Shale roof.

1. Shaly coal.

Ft. in.

2. Bone.

11

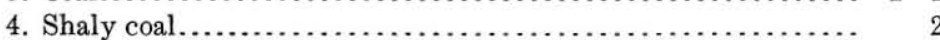

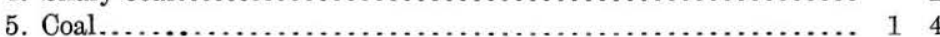

Firm sandstone floor. Strike, N. $91^{\circ}$ E.; dip, $30^{\circ} \mathrm{N}$.

A section of the coal at the Johnson tunnel, which is on the south slope of the Mine Creek valley about 870 feet above sea level, is as follows:

- Section of the Johnson tunnel coal bed, Mine Creek, Herendeen Bay.

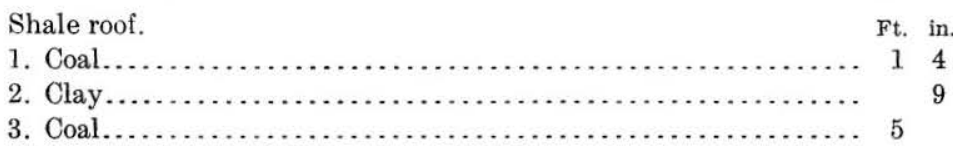

Clay floor. Strike, N. $101^{\circ}$ E.; dip, $34^{\circ}$ NE.

Samples of coal, analyses of which appear on page 105, were taken from each of the above beds. No work had been done in the lower tunnel during the 10 months preceding the examination. Material from beds 1 to 5 in the above section was included in this sample (laboratory No. 6957). The Johnson tunnel had also been closed fully 10 months, but a sample (laboratory No. 6951) was procured from bed 3 in the above section.

The Johnson tunnel is about 100 feet long. The coal continues for about 75 feet, becomes much broken, and finally disappears through faulting. Some prospecting for the continuation of this bed has been done, but it has not yet been located. In drifting it has been necessary to use timber to support the roof. Of late, coal has been mined here for local consumption only, and the amount mined has been only a few tons each year.

The lower tunnel is located near the stream bed, 275 feet above sea level, and has been driven for 150 feet along the strike of the coal. The roof is firm, and no timbering was necessary except at the entrance. About 20 tons were taken from this drift in 1907 for use in drilling and for domestic purposes. The walls of the drift indicate minor faulting at various places, the movements ranging from a few inches up to a foot. The condition is typical of the distributive faulting associated with the larger movements in the field, and is of the same general character.

Three drill holes have been put down in the lowlands near the mouth of Mine Creek, in the deepest, which reached a depth of 350 
feet, thin strata of coal were found. The other holes were sunk 150 feet and 28 feet. The work was delayed by the loss of tools. As yet no coal of minable thickness has been found by drilling.

The coal exposed at Coal Bluff appears at the surface to be of as high grade as that outcropping at several other places. The coal exposed near the headwaters of Coal Creek, in certain of the tributaries from the west, and in the continuation in the opposite side of the syncline of the coal belt in which the Johnson tunnel is located, appears to be of good grade and faulting has not so greatly disturbed the formations in this part of the field. During the writer's visit, however, this part of the field contained so much snow that the coals could not be satisfactorily examined.

CHARACTER OF THE COAL.

PHYSICAL PROPERTIES.

In the tunnels the coal is generally very firm and nowhere badly shattered. Even in places where mining work had been abandoned nearly a year little loose material had fallen from the seam, though in such places the coal, which in the regular work of mining would probably come out in large blocks, could be readily worked out with a pick in lumps 4 to 5 inches in diameter. Thin bony streaks and fine shale partings, though not conspicuous, indicate on close examination the bedded structure of the coal. The coal in the lower tunnel in Mine Creek is of medium hardness, is firm and bright, and possesses the physical properties characteristic of a good grade of bituminous coal. Several tons of coal had been mined and stacked near the entrance to Johnson tunnel during the previous summer. This coal had been exposed to rains, to the waters from melting snows, and to changes in temperature throughout the year. It was not directly exposed to the sun's rays, however, and had not slacked badly.

The surface of the coal, in the exposures where tunnels have not been made, although it has been exposed to the processes of weathering for at least many years, has not been much affected. Where the seams were uncovered by shoveling away snow the coal was found to be in a firm, hard condition, but in such places the processes of weathering have emphasized the bedded structure of the coal seam. High elevations on the mountain side, where the coal outcrops in parallel ridges, the black bands often project in such form as to indicate that the coal is more resistant to the processes of weathering than the shales associated with it. The fuel in these exposures has the properties of true bituminous coal.

The lignites exposed east of Point Divide, on the west side of Herendeen Bay, and in the central portion of the peninsula east of the trail to Balboa Bay are soft and of dull black or brown colors. 
The seams are divided by numerous shaly partings, and the amount of black shale in each seam is so great that this material will probably not prove to be of much commercial value.

COMBUSTION.

Coal from the Mine Creek tunnels was used during the field season in cookstoves. It burned with a medium-length yellow flame and with little smoke, the length of the flame and the amount of smoke being least in coal from the Johnson tunnel. The coal from these tunnels fuses and cakes somewhat on beginning to burn. The ashes are soft and fine, with but little clinker. No combustion tests were made from the coal outcrops where no mining had been done.

CHEMICAL AND CALORIMETRIC PROPERTIES.

Methods of sampling.-In collecting samples from this field positions were selected where complete and characteristic sections of the beds were exposed and where the effects of weathering were as slight as possible. In the tunnel the position selected was near the place where the work of mining had been discontinued. A fresh cut was then made across the bed from roof to floor, cleaning off the dirt and weathered coal as far as possible. A waterproof cloth was spread to catch the coal and a sample, including all parts of the bed except such shale and other bedded impurities as could readily be separated in the ordinary practices of actual mining, was cut from the roof to the floor. The sample was then pulverized and carefully quartered. A 3-pound sample prepared in this way was sealed at once in an airtight can, which was not opened until the coal was analyzed.

Methods of analysis.-The samples collected were analyzed by F. M. Stanton, of the United States Geological Survey, using the standard methods ${ }^{1}$ adopted in that work at the fuel-testing plant.

Analyses.-The following table gives the results of the proximate analyses of some of the coals from the Herendeen Bay, Chignik Bay, and Unga Island fields. The analyses of the coal as received have been recalculated to obtain the analyses on the air-dried basis. The samples were obtained at the following localities:

6952. Coal bed on west side of main stream, 7 miles northwest of Hook Bay, east side of Chignik Bay, Alaska Peninsula.

6956. Chignik Bay, Thompson Valley, three-fourths of a mile above mouth of stream. 6955. Chignik Lagoon, Whalers Creek, three-fourths of a mile above mouth.

6953. Chignik River, north side, 2 miles below Chignik Lake.

6957. Herendeen Bay, Mine Creek, three-fourths of a mile above mouth.

6951. Herendeen Bay, Mine Creek, $1 \frac{1}{1}$ miles above mouth.

6954. Unga Island, Coal Harbor, $1 \frac{1}{4}$ miles west-northwest of Gull Island.

1 Bull. U. S. Geol. Survey No. 261, 1905, pp. 19-20; Prof. Paper U. S. Geol. Survey No. 48, 1906, pt. 1, 177-193; Bull. U. S. Geol. Survey No. 290, 1906, pp. $29-30$. 
Analyses of Chignik Bay, Herendeen Bay, and Unga Island coais.

[Analyses by F. M. Stanton, U. S. Geological Survey.]

SAMPLES AS RECEIVED.

\begin{tabular}{|c|c|c|c|c|c|c|c|c|c|c|c|c|c|c|}
\hline \multirow[b]{2}{*}{$\begin{array}{l}\text { Lab. } \\
\text { No. }\end{array}$} & \multirow[b]{2}{*}{ Locality. } & \multicolumn{6}{|c|}{ Proximate analyses. } & \multicolumn{5}{|c|}{ Ultimate analyses. } & \multicolumn{2}{|c|}{ Calorific value. } \\
\hline & & $\begin{array}{c}\text { Loss } \\
\text { on air } \\
\text { drying. }\end{array}$ & $\begin{array}{c}\text { Total } \\
\text { moisture. }\end{array}$ & \multicolumn{2}{|c|}{$\begin{array}{c}\text { Volatile } \\
\text { com- } \\
\text { bustible. }\end{array}$} & $\begin{array}{c}\text { Fixed } \\
\text { carbon. }\end{array}$ & Ash. & Sulphur. & Hydrogen. & Carbon. & Nitrogen. & Oxygen. & Calories. & $\begin{array}{c}\text { British } \\
\text { thermal } \\
\text { units. }\end{array}$ \\
\hline $\begin{array}{l}6952 \\
6956 \\
6955 \\
6953 \\
6957 \\
6951 \\
6954\end{array}$ & 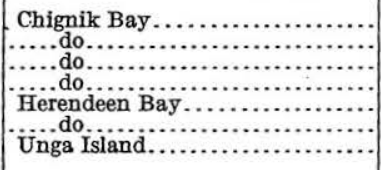 & $\begin{array}{r}4.00 \\
6.50 \\
2.50 \\
5.20 \\
4.60 \\
5.30 \\
12.50\end{array}$ & $\begin{array}{r}5.07 \\
10.77 \\
5.02 \\
7.06 \\
7.48 \\
8.01 \\
23.27\end{array}$ & & $\begin{array}{l}7.24 \\
0.37 \\
4.28 \\
1.48 \\
2.13 \\
3.53 \\
5.42\end{array}$ & $\begin{array}{l}42 . \\
43 . \\
45 . \\
39 . \\
48 . \\
51 . \\
25 .\end{array}$ & $\begin{array}{r}25.27 \\
14.87 \\
15.25 \\
21.78 \\
11.62 \\
7.11 \\
26.18\end{array}$ & $\begin{array}{l}2.26 \\
.70 \\
1.75 \\
1.30 \\
.31 \\
.41 \\
.53\end{array}$ & $\begin{array}{l}\text { 4. } 53 \\
\text { 4. } 98 \\
4.87 \\
\text { 4. } 83 \\
5.11 \\
5.41 \\
5.27\end{array}$ & $\begin{array}{l}55.76 \\
55.27 \\
62.04 \\
55.14 \\
63.49 \\
66.44 \\
34.76\end{array}$ & $\begin{array}{l}0.59 \\
.61 \\
.56 \\
.61 \\
.91 \\
.80 \\
.52\end{array}$ & $\begin{array}{r}8.38 \\
23.57 \\
15.53 \\
16.34 \\
18.56 \\
19.83 \\
32.74\end{array}$ & $\begin{array}{l}5,618 \\
5,356 \\
6,245 \\
5,470 \\
6,256 \\
6,547 \\
3,227\end{array}$ & $\begin{array}{r}10,112 \\
9,641 \\
11,241 \\
9,846 \\
11,261 \\
11,785 \\
5,809\end{array}$ \\
\hline \multicolumn{15}{|c|}{ AIR-DRIED SAMPLES (CALCULATED FROM TABLE ABOVE). } \\
\hline \multirow[b]{2}{*}{$\begin{array}{l}\text { Lab. } \\
\text { No. }\end{array}$} & \multirow[b]{2}{*}{ Locality. } & \multicolumn{5}{|c|}{ Proximate analyses. } & \multicolumn{6}{|c|}{ Ultimate analyses. } & \multicolumn{2}{|c|}{ Calorific value. } \\
\hline & & Moisture. & $\begin{array}{c}\text { Volat } \\
\text { com } \\
\text { bustib }\end{array}$ & & $\begin{array}{l}\mathrm{Fi} \\
\text { carl }\end{array}$ & $\begin{array}{l}\text { xed } \\
\text { bon. }\end{array}$ & Ash. & Sulphur. & Hydrogen. & Carbon. & Nitrogen. & Oxygen. & Calories. & $\begin{array}{c}\text { British } \\
\text { thermal } \\
\text { units. }\end{array}$ \\
\hline $\begin{array}{l}6952 \\
6956 \\
6955 \\
6953 \\
6957 \\
6951 \\
6954\end{array}$ & 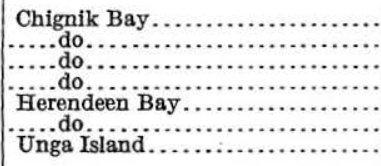 & $\begin{array}{r}1.11 \\
4.57 \\
2.58 \\
1.96 \\
3.02 \\
2.86 \\
12.31\end{array}$ & $\begin{array}{r}28 \\
32 \\
35 \\
33 \\
33 \\
35 \\
29\end{array}$ & $\begin{array}{l}8.38 \\
2.48 \\
5.16 \\
3.21 \\
\text { 3. } 68 \\
5.41 \\
9.05\end{array}$ & & $\begin{array}{l}44.19 \\
47.05 \\
46.62 \\
41.86 \\
51.12 \\
54.22 \\
28.72\end{array}$ & $\begin{array}{r}26.32 \\
15.90 \\
15.64 \\
22.97 \\
12.18 \\
7.51 \\
29.92\end{array}$ & $\begin{array}{r}2.35 \\
.75 \\
1.79 \\
1.37 \\
.32 \\
.43 \\
.60\end{array}$ & $\begin{array}{l}\text { 4. } 26 \\
4.56 \\
4.71 \\
\text { 4. } 48 \\
4.82 \\
5.09 \\
4.44\end{array}$ & $\begin{array}{l}58.08 \\
59.11 \\
63.63 \\
58.17 \\
66.55 \\
70.16 \\
39.73\end{array}$ & $\begin{array}{l}0.61 \\
.65 \\
.57 \\
.64 \\
.95 \\
.84 \\
.59\end{array}$ & $\begin{aligned} 8.38 \\
19.03 \\
13.66 \\
12.37 \\
15.18 \\
15.97 \\
24.72\end{aligned}$ & $\begin{array}{l}5,852 \\
5,728 \\
6,405 \\
5,770 \\
6,558 \\
6,913 \\
3,688\end{array}$ & $\begin{array}{r}10,533 \\
10,310 \\
11,529 \\
10,386 \\
11,804 \\
12,343 \\
6,638\end{array}$ \\
\hline
\end{tabular}


POSITION OF THE COAL MEASURES.

Mining conditions are not especially difficult in the portion of the field where work has already been done. The coal outcrops at elevations ranging from sea level to at least 1,200 feet above sea level. Coal may be easily taken to tidewater from the lower drift in Mine Creek. A good horse trail now leads to the mouth of this tunnel, and it would not be difficult to construct a wagon road or railroad to that point. The Johnson tunnel, which is driven at an elevation of 870 feet, is less favorably located for transporting coal. The horse trail to the lower tunnel reaches this higher opening as well, but the ascent is for a part of the way difficult, though coal has been packed out on horses over the trail. The construction of a road from this opening would be expensive, but the coal might easily be carried by tramways to more accessible places in the valley. The exposures near the head of Coal Valley are at elevations of 1,000 to 1,200 feet above sea level. Coal is exposed in Coal Bluff, on the east side of Herendeen Bay, from sea level to the top of the bluff, an elevation of about 50 feet. The lignite exposures east of Point Divide and those on the west side of Herendeen Bay are in the cliff bordering the beach, and the lignite seams along the trail to Balboa Bay at elevations between 600 and 800 feet above sea level.

In the portion of the field where the bituminous coal occurs there is evidently a large supply of high-grade fuel above sea level. The structure is such at two places that the coal may be expected to pass below sea level, but it is not safe to conclude that there is any large supply of coal below sea level.

DIP OF THE COAL MEASURES.

The coal seams exposed in Mine Creek dip at angles varying from $25^{\circ}$ to $35^{\circ}$, and on two sides of a westward-plunging synclinal fold, of which the axis coincides approximately with Mine Creek. At the head of Coal Valley the coal seams rest at angles of $13^{\circ}$ to $20^{\circ}$. At Coal Bluff the dip of the coal measures is $31^{\circ}$. The lignite-bearing beds east of Point Divide extend at an angle of about $22^{\circ}$, and those on the west side of Herendeen Bay have dips of $31^{\circ}$ to $46^{\circ}$. The lignite beds in the central portion of the peninsula rest at angles of $22^{\circ}$. The faulting that has distributed the formations has not been on a large scale, and when the structure is worked out in detail there should not be much difficulty in locating the coal in the different fault blocks. The exposures are so good in this field that a detailed survey on a large scale would furnish data for estimating with a high degree of accuracy the actual amount of coal in each portion of the field, and would probably make it possible to estimate the positions of the less broken portions of the coal. 
EXTENT OF THE COAL MEASURES.

When the writer was at work in this field there was, unfortunately, a heavy covering of snow over portions where coal measures must exist, but in spite of these conditions the coal measures were traced eastward from Herendeen Bay to a point within a few miles of Port Moller, where they were found to pass beneath recent volcanic rocks. Since coal has been found at the same geologic horizon in the Chignik Bay region, and is there exposed for many miles, it is reasonable to suppose that there may be other exposures of this coal-bearing formation in the region between Port Moller and Chignik Bay, a part of the peninsula that is not yet surveyed. The lignitebearing formation on the west side of Herendeen Bay is reported to continue far, to the westward, but work was not carried on in that direction.

SHIPMENT.

If these coals are mined on a large scale, they should be carried by railway to Balboa Bay for shipment (fig. 16). The route from Mine Harbor to Balboa Bay is about 16 miles long and an easy one for railway construction. Mine Harbor is well protected and is deep enough for commercial purposes, but for several months each year Mine Harbor and the upper part of Herendeen Bay are locked in ice. Coal

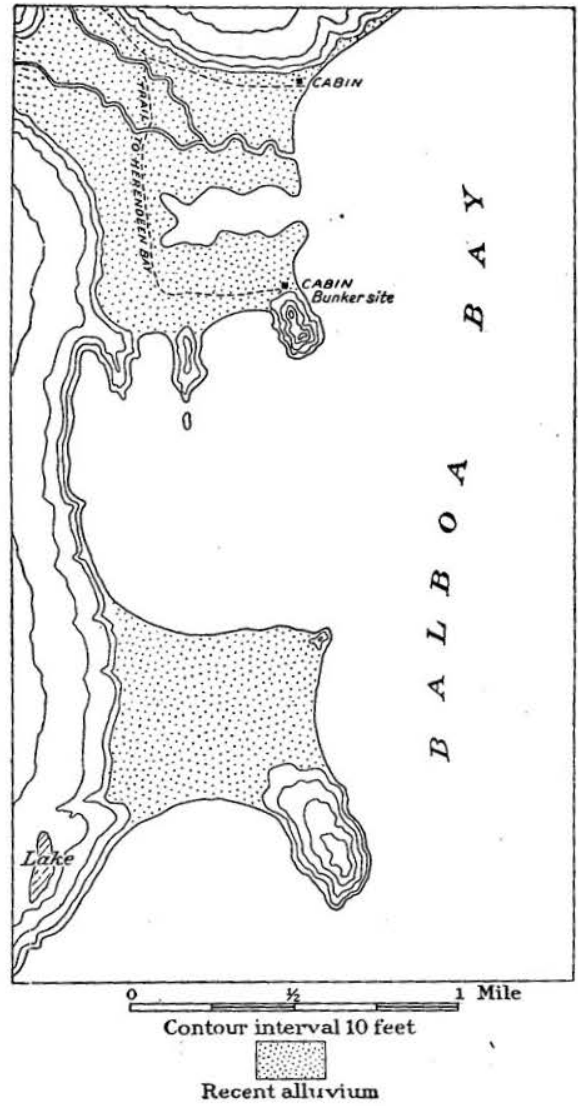

FIGURE 16.-Sketch map of the shore features near the head of Balboa Bay, which has been selected as a railroad terminus.

could be shipped during the summer by way of Herendeen Bay to Bering Sea and thence to Alaskan ports farther north. If coal is mined from the head of Coal Valley, the problem of taking it to tidewater on the Pacific side of the peninsula is a little more difficult. A railroad could be constructed along Coal Valley and connected with Mine Harbor by a circuitous route, which would add about 15 
miles to the direct route and double the length of the haul to the Pacific. At Balboa Bay an excellent harbor and good bunker sites are available (fig. 16).

CHIGNIK BAY COAL FIELD.

GEOGRAPHY.

Chignik Bay lies on the Pacific side of Alaska Peninsula, in longitude $158^{\circ}$ west and latitude $56^{\circ} 20^{\prime}$ north. (See Pl. VI, in pocket.) The coal belt stretches from Chignik River, on the southwest, toward the northeast, beyond the head of Hook Bay, and parallels the western shore of Chignik Bay for a distance of at least 30 miles. (See Pl. VII, p. 40.)

A small reentrant on the south shore of Chignik Bay, known as Anchorage Bay (Pl. XI, $B$, p. 86), provides an excellent harbor, and beside this bay the Chignik post office is located. A small steamer from Seward calls at this port once each month. Chignik Lagoon and Mallard Duck Bay, to the west, are nearly cut off from the larger body of water by a sand and gravel spit. A sand bar at the entrance makes the inner harbor unavailable for boats drawing more than 12 feet of water. An irregular channel leads through the lagoon to the mouth of Chignik River, but the larger portion of the lagoon is dry at low tide. Chignik River furnishes a water route to a chain of lakes in the central part of the peninsula, and from these lakes small boats may, after a short portage, descend to Bering Sea. Boats drawing more than 2 feet of water can not safely navigate the Chignik except at high tide, when small launches drawing barges can ascend the river as far as the coal mine.

Hook Bay lies near the north entrance to Chignik Bay. It is bordered in part by alluvial lands and in part by rugged cliffs. The sheltered waters on the south side of Hook Bay afford an excellent harbor (Pl. XIII, $A$ ).

The area underlain by coal west of Chignik Bay is on the southeast slope of the main mountain belt of the peninsula. The summits reach elevations of about 2,500 feet, and the broad anticlinal structure gives long, gentle slopes to the mountains. A series of nearly parallel valleys of open U-shaped forms cross from the summit region to the margin of Chignik Lagoon and Chignik Bay. In these valleys and in the intervalley areas, above the heavy covering of grasses and mosses, the formations are well exposed.

The winter snows do not leave the lower lands until April or May. During the summer there is considerable rain and much cloudy weather, and by the latter part of September fresh snows begin to appear on the mountains. The climatic conditions from April to October are not, however, such as to interfere with out-of-door work. 


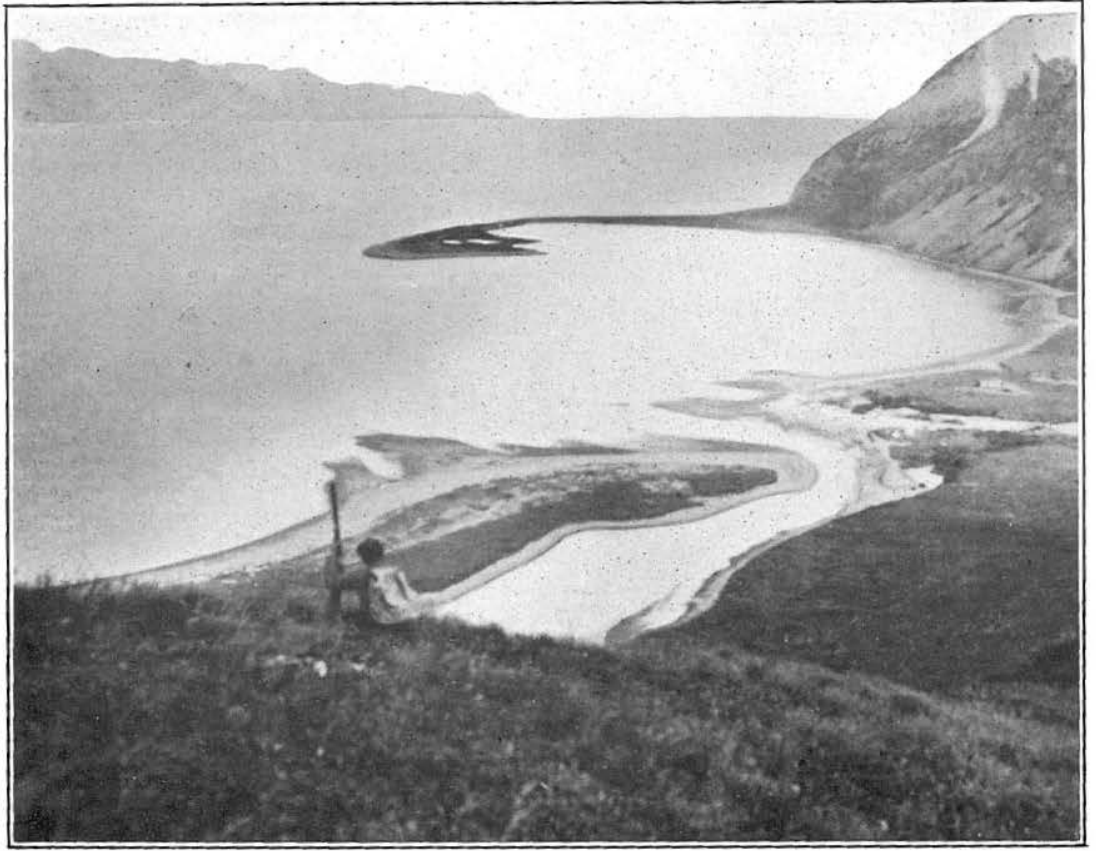

A. HOOK BAY, NEAR NORTH ENTRANCE TO CHIGNIK BAY.

This is the nearest harbor to the coal prospects northwest of this bay. The lowland at the left has been selected for a town site. See pages $93,108,114$

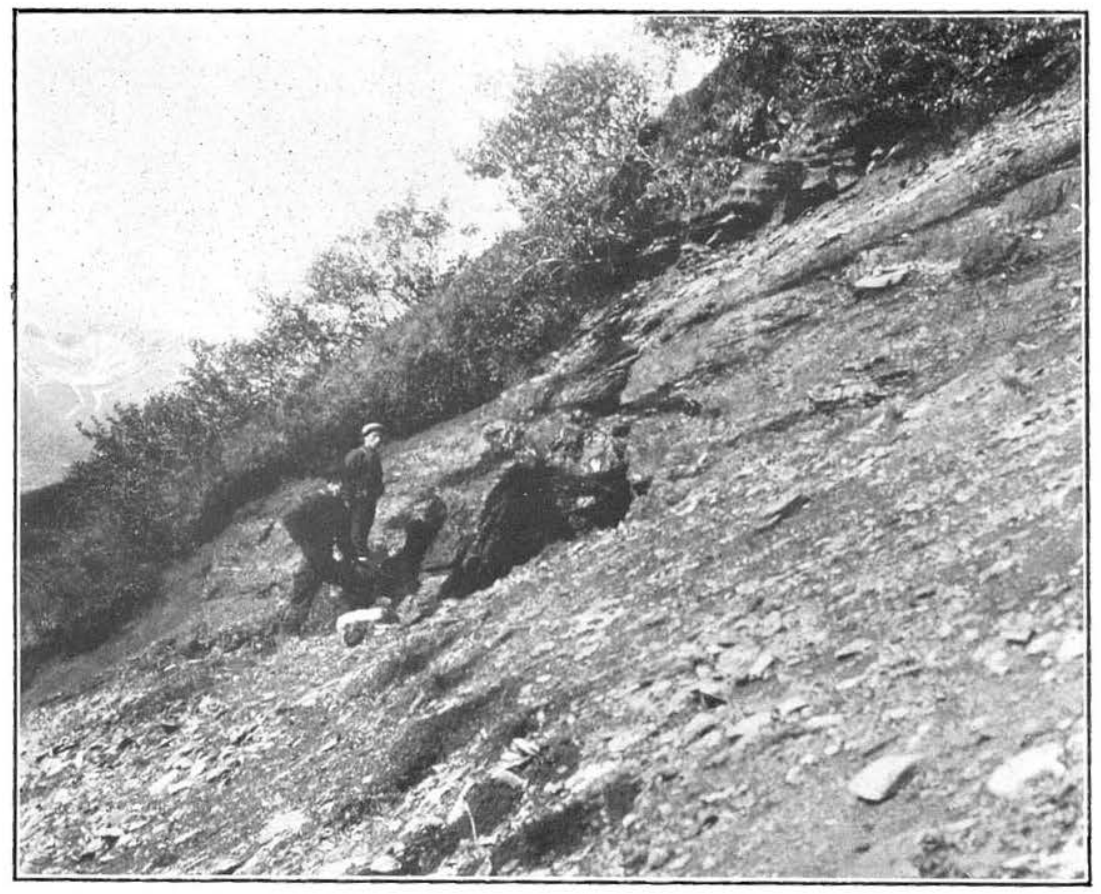

b. EXPOSURE IN THE UPPER COAL SEAM IN THOMPSON VALLEY.

See page 112. 

The Alaska Packers' Association has a cannery in this region, on the south shore of Chignik Lagoon, and the Northwestern Fisheries Co. one at Anchorage Bay.

Development work in this field has been described on page 20 of this report.

AREAL EXTENT.

The actual known extent of coal in this field does not exceed 15 square miles, but from the distribution of the coal outcrops and the general geologic structure in the field it is probable that coal underlies an area of between 40 and 50 square miles.

A few thin lignite seams occur in the Kenai formation on the southwest side of Chignik Bay. The areal extent of these lignite seams will probably be found to be between 10 and 20 square miles, but the quality of this material is not such as to make it of economic value.

GEOLOGY.

STRATIGRAPHY.

The bituminous coal in the Chignik Bay region is of Upper Cretaceous age and belongs to the Chignik formation. The coal measures occur in the middle portion of that formation, and are underlain and overlain by thin beds of sandstones and shales. The Upper Cretaceous (Chignik formation) in this region rests unconformably upon the Upper Jurassic (Naknek formation), but it is overlain conformably by the Kenai formation, of Eocene age. This section is shown along Chignik River and along the shores of Chignik Lagoon.

STRUCTURE.

The sedimentary series in this coal field is known to include Jurassic, Upper Cretaceous, and Eocene rocks. The absence of Lower Cretaceous fossils in the collections procured in this region is remarkable, for that horizon is well represented at Herendeen Bay, about 100 miles west. A description of the sedimentary formations of this portion of the peninsula is given on pages 29 to 84 .

The structure of the central part of the peninsula is that of a broad anticline, the axis of which extends at least as far southwest as Pavlof Bay. In this region the axis of the fold passes northwest of Chignik Bay through Chignik Lake, and thence northeast along the crest line of the Aleutian Range. East of Chignik Lagoon and along the south shore of Chignik Bay the sedimentary strata are gently folded and somewhat faulted. Near the upper limit of the sedimentary rocks the number of intruded sheets of lava increases notably until at last the sediments are succeeded by vast flows of lava. Great quantities of fragmental material have been erupted, and large streams of lavas outpoured from two or three former 
centers of volcanic eruption in the vicinity of Hook Bay, and as a result large blocks of sedimentary formations have been disturbed.

A great mass of igneous rocks, chiefly andesites and basalts, lies south of a line passing through Chignik Lagoon and west of Anchorage Bay. Basaltic dikes are common in the area bordering these igneous rocks. South of Anchorage Bay there is a huge mass of dacitic rock, with which apparently are associated a number of sills. Other sills are well exposed on the north shore of Anchorage Bay, while similar masses of dacite occur in the vicinity of Hook Bay. Only in the extreme northeastern and southwestern parts of the coal belt do igneous rocks come into close contact with the coal, and in those places the coal does not appear to have been affected by the igneous activities.

The structure in this field is much simpler than that near Herendeen Bay, and detailed geologic work will readily determine the amount and distribution of the coal.

THE COAL MEASURES.

The formation that contains the bituminous coal in this region is of Upper Cretaceous age. It is well exposed in the Chignik Bay region and has therefore been named the Chignik formation. The known and probable distribution of the Chignik formation in the vicinity of the bay of that name has been indicated on Plate VII. The same formation, however, is known farther to the northeast and to the southwest (Pl. VI, in pocket), and it is very probable that outcrops occur in the intervening unsurveyed portions of the peninsula. The coal measures consist of sandstones, shales, and conglomerates, interstratified with the coal seams.

The developed coals are at Chignik River, Whalers Creek, Thompson River, and northwest of Hook Bay. Some detailed sections of these coals are given in figure 15, and a description of each locality will be given in the following paragraphs.

Chignik River.-The coal bed that has been worked outcrops on the river bluff 3 miles above the head of Chignik Lagoon (Pl. XIV, $A$ ), and has been traced inland for a little more than half a mile. At this locality it strikes N. $2^{\circ} \mathrm{E}$. and dips $24^{\circ} \mathrm{E}$. A section of the bed measured in the drift is as follows:

Section of Chignik River coal bed.

Ft. in.

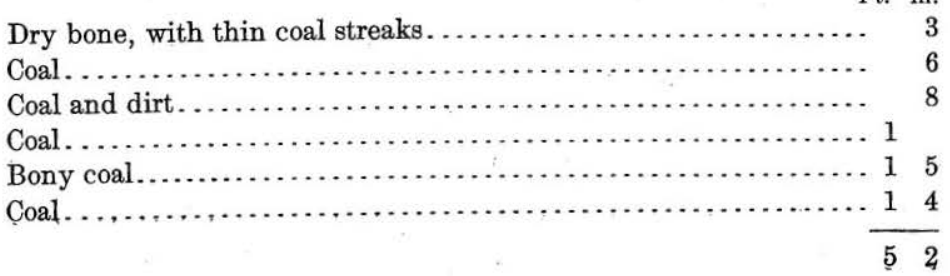




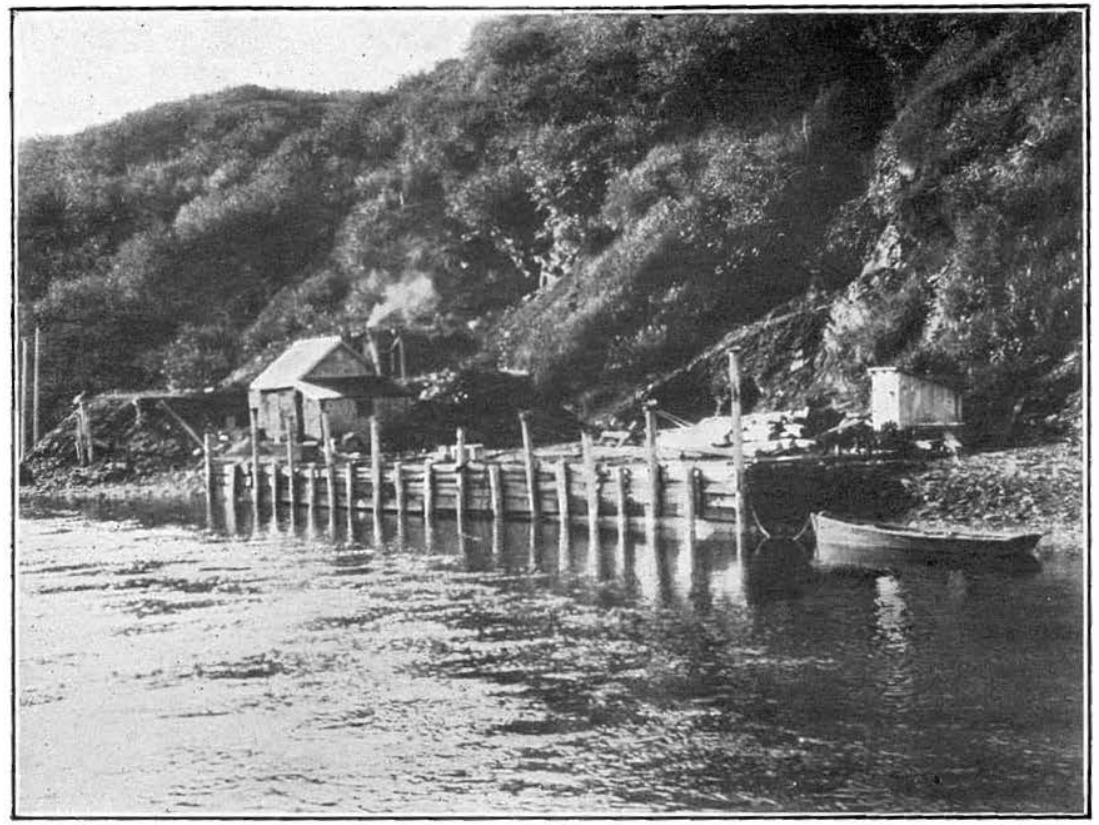

A. entrance to ChIGNIK RIVER COAL MiNe.

See page 110.

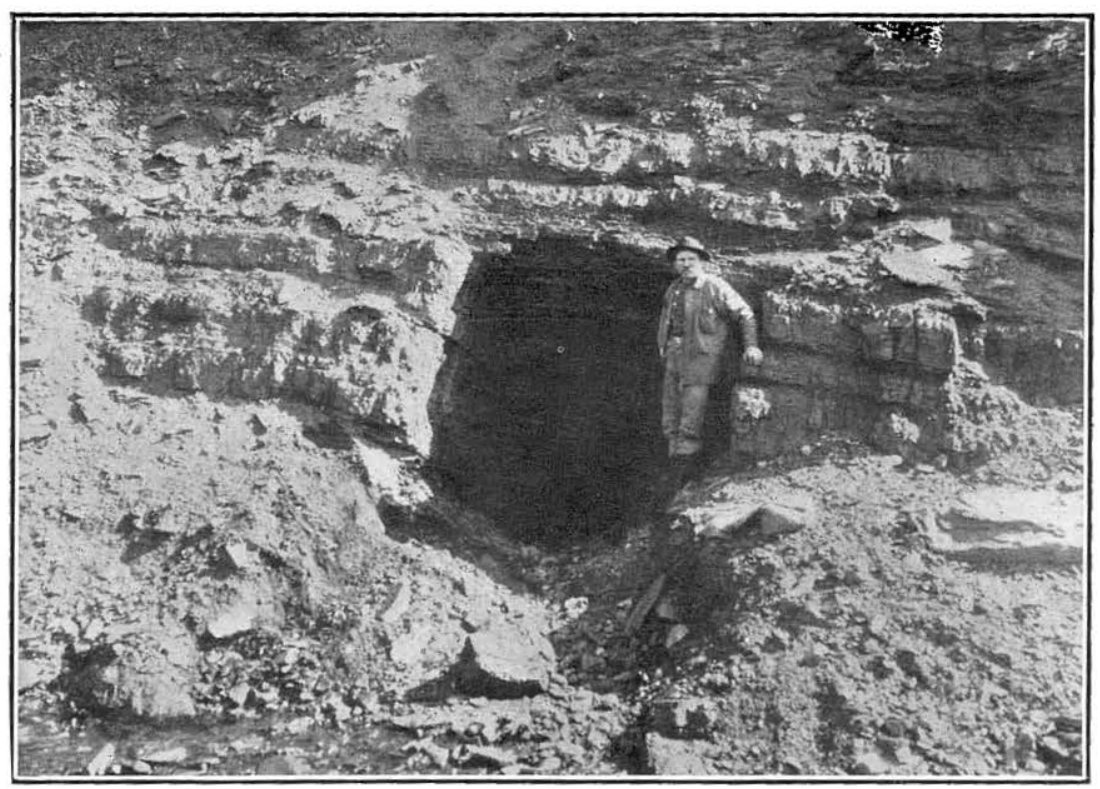

B. TUNNEL OPENING IN WHALERS CREEK COAL SEAM.

See page 111. 

The roof, which is of shale with thin layers of coal overlain by sandstone, is very even. The floor, however, is not so regular, and the roll or swelling in it reduces the thickness of the bed at the end of the drift from 5 feet to 9 inches. It is possible that the roll, which is known to be rather long, may be narrow, and that a short tunnel driven through it would discover the full thickness of the coal bed on the other side.

The coal is solid and bright, and comes out in good-sized pieces. When used under a boiler it has to be stoked very frequently to keep it burning freely. It is a fairly satisfactory steaming coal when it is properly handled, but it makes a large amount of ash and the fires have to be cleaned often. An analysis of this coal is given on page 105.

The Chignik River mine is worked throughout the year by two men without machinery, the coal being undercut by hand and shot down. Coal outcrops appear at several other places on the north - bank of Chignik River east of the mine, but the beds do not appear to be of as good grade as that at the mine and have not been worked as yet.

Whaters Creek.-Whalers Creek is a small stream entering Chignik Lagoon from the north, a short distance below the mouth of Chignik River. Coal is exposed for 600 feet along the northernmost of the three main branches of the creek, the exposure being along the strike of the coal measures, which outcrop at the coal mine on Chignik River. The strike of the coal is N. $5^{\circ} \mathrm{E}$. and the dip is $22^{\circ} \mathrm{E}$. The section of the coal is as follows:

Section of Whalers Creek coal bed.

Shaly sandstone roof.

Ft. in.

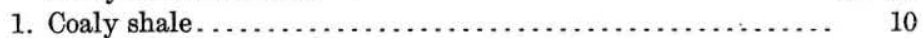

2. Shale. . . . . . . 8 .

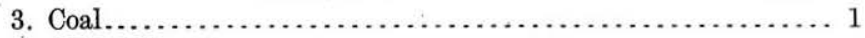

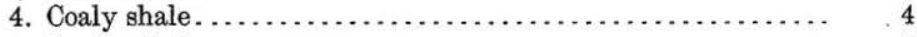

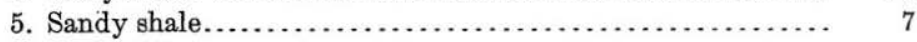

6. Coal with slate partings. . . . . . . . . . . . . . . . . 5

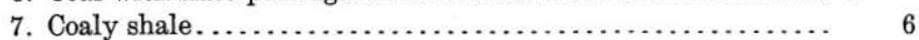

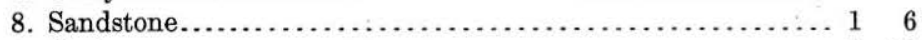

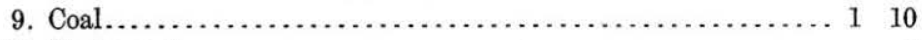

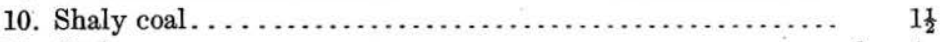

11. Coal.......................................... 4

Sandy shale floor.

The slope, which has been driven 130 feet on the coal, follows the lower part of the bed and includes the strata numbered $\delta$ to 11 in the above section (Pl. XIV, B). The coal bed (Nos. 9 to 11) was sampled in the usual way and analyzed, with the result given on page 105 (laboratory No. 6955). 
The coal is bright, black, and blocky, very much like that mined at. Chignik River, but at this locality the section of the coal is better in that the partings are thin. A nearly vertical fault, about 500 feet downstream from the mine opening, probably cuts off the coal bed. On the upstream side, about 40 feet from the opening, a vertical fault throws the coal down 6 feet, and 115 feet upstream from the mine another fault, which cuts off the coal, has been reported. This upper portion of the valley was filled with snow when the region was visited by the writer.

Although faults have disturbed the coal somewhat, there appears, nevertheless, to be a very considerable body of good coal available. The location of this coal favors shipment on small boats down Chignik Lagoon or by rail. A railway might be built across Chignik River a short distance-above the mouth and thence across a lowland area to the head of Kuiukta Bay, where excellent harbor facilities are reported. The distance from Whalers Creek to the head of Kuiukta Bay by the proposed railway route is about 5 miles.

Coal has been reported to outcrop at several places high on the mountain slopes northeast of the outcrops of coal in Whalers Creek. The localities pointed out in the field by prospectors are along the general strike of the coal measures and presumably contain the same beds that are exposed elsewhere in the field.

Thompson Valley.-Thompson Valley lies northwest of the northern portion of Chignik Bay, and is a broad, open, flat-bottomed valley, heading among the high mountains at least 10 miles from the beach. Coal is exposed on the northeastern slope $1 \frac{3}{4}$ miles from the beach and 300 feet above the valley floor (Pl. XIII, B, p. 108). The strike of the beds is N. $61^{\circ} \mathrm{E}$. and the dip is $21^{\circ} \mathrm{NW}$. Two workable coal beds are exposed for at least a mile, and their extent is probably much greater. Where the tributary streams to Thompson Valley cross these coals there are falls or cascades in their courses. The detailed measurements of these beds are given below:

Sections of coal beds in Thompson Valley.

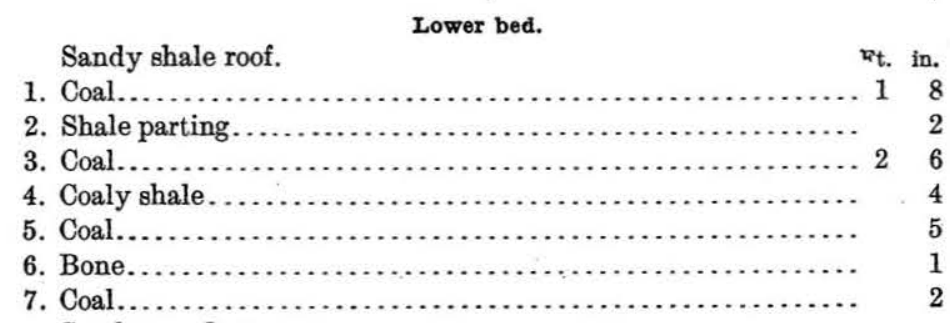

Sandstone floor. 
Upper bed.

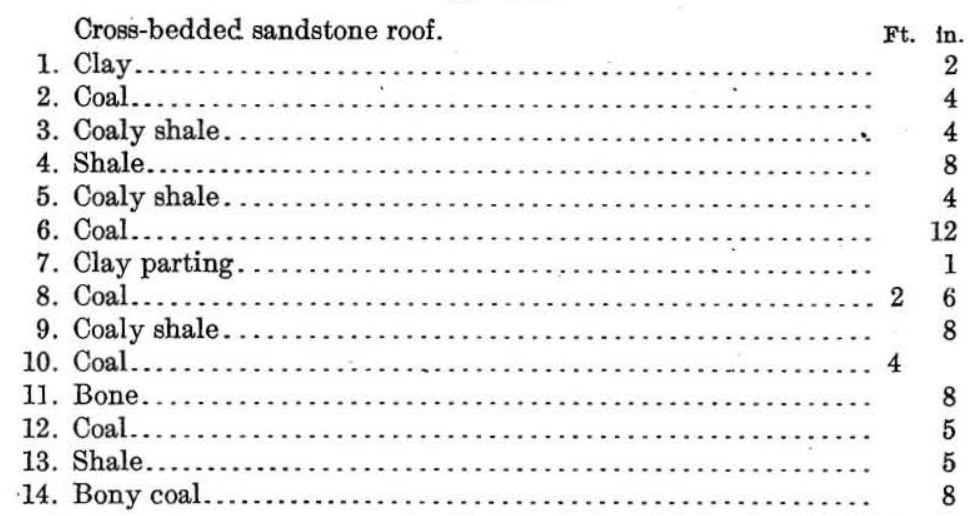

The analysis of a sample taken from the beds numbered 6,8 , and 10 in the foregoing section of the upper coal is given on page 105 (laboratory No. 6956).

A large body of good coal is available at this locality. The conditions for mining are favorable, and the space at the base of the bluff is ample for mine buildings and mine bunkers. The chief difficulty in the way of exploiting this coal is in making arrangements for shipping. The beach at the mouth of Thompson Valley is exposed to the severe storms from the Pacific Ocean. A railway from the valley to Chignik Lagoon could be easily built, for the route would be over a lowland area and not more than 9 miles in length. The conditions in Chignik Lagoon, however, are not favorable for loading large ocean-going vessels. Hence it would probably be necessary to continue the railway along the northwest shore of the lagoon and then by the same route as that from Whalers Creek to the head of Kuiukta Bay, as already described.

Hook Bay.-Hook Bay is in the northern part of the field examined. The coal in this vicinity occurs near the headwaters of the right-hand branch of the stream entering Hook Bay from the west and in the foothills of the main mountain range. The general strike of the beds is $\mathrm{N} .11^{\circ} \mathrm{E}$. and the dip $34^{\circ} \mathrm{E}$. The section of the coal is as follows:

Section of Hook Bay coal bed.

Firm sandstone roof.

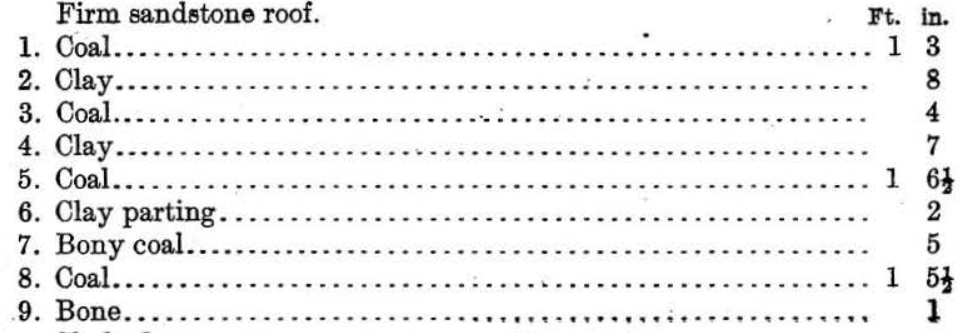

Shale floor.

$90054^{\circ}-$ Bull. $467-11-8$ 
Above this bed is an 8-foot bed of sandstone overlain by a thin layer of coal. Below the main bed of coal lies a 4-foot layer of shaly sandstone; underlain by a 3 -foot bed of coal, in the middle of which is a 6-inch parting of shale. The exposures in the tunnel show the coal to be uniform in thickness and quality.

In sampling this bed a cut was made across Nos. 5 to 8 , inclusive, in the above section. The analysis is given on page 105 (laboratory No. 6952).

The strike, so far as the beds could be examined, is uniform, and appears to continue without notable break for at least half a mile to the northeast. The tunnel opening is 50 feet above the stream bottom, where there is space for mine buildings. At present there is a wagon rood from Hook Bay to the coal croppings, along a stream bottom where the general gradient and space would be favorable to railway construction. Hook Bay is an excellent small harbor (Pl. XIII, $A$, p. 108), and is bordered by favorable sites for wharves and bunkers. The distance from the harbor to the coal is about 8 miles. At present four claims are staked out in this field, and development work is being done under the auspices of the Alaska Peninsula Mining \& Trading Co.

CHARACTER OF THE COAL

PHYSICAL PROPERTIES.

The coal from the Chignik River mine is bright black and of medium hardness. It is worked out in lumps ranging up to 10 and 12 inches in diameter. The seam, as exposed late in the season, of 1908, showed some crushing at the front wall and at the end of the tunnel. The section in the mine shows sufficient shale partings and bony streaks to indicate the general bedded structure of the coal, which corresponds to the general dip of the formations in that part of the field. The coal, when taken from the mine, is dumped upon a barge near the entrance of the tunnel, and is unloaded from the barge and dumped into the coal bins at the cannery, where it is used. In the processes of handling, the coal usually becomes broken into fragments ranging up to 3 or 4 inches in diameter. This coal does not appear to slack badly. The best exposures in Whalers Creek are in a prospecting tunnel, where the coal seam is firm and the bedded structure pronounced, the structure being emphasized by certain shale partings. The coal is a dull black on the weathered surfaces, but is bright in fresh exposures. The Thompson Valley exposures are only a little beneath the surface, and not beyond the zone of weathering. This coal, however, is in a heavy firm bed, more resistent than the shales and sandstones associated with it, as is indicated by the rapids or falls where streams cross the coal seam. 
In the short tunnel in the coal northwest from the head of Hook Bay, the coal is in seams 18 inches or less in thickness, separated by thin beds of shale. These shale partings indicate the general bedded condition of the sediments, and correspond with the general dip of the strata. The upper portion of the seam is bright and black, and of medium hardness, and appears to be a high grade of bituminous coal. The lower portion of the seam has more bony streaks, but would average a fair grade of bituminous coal.

COMBUSTION.

The burning of the coal from the Chignik River mine was observed under the boiler of a small steam tug. The flame was distinctly yellow and the coal burned freely, but there was a large proportion of ash and some clinkering. The fireman on the tug complained that this coal does not hold the fire well. Persons who have used the coal estimate that there is about 25 per cent ash in the coal as it comes from the mine. The coal from the other exposures in the Chignik Bay region is not as yet in use.

CHEMICAL AND CALORIMETRIC PROPERTIES.

It was customary to select a position where a complete and characteristic section of the bed was exposed in sampling the coal seams in the various portions of this field, and accordingly, where tunnels had been driven, the positions selected were at or near the face of the tunnel. An effort was made to remove from the surface the loose and weathered portion of the coal seam where no tunneling had been done, but it was not practicable to go beneath the zone which had been affected by surface weathering, and it is probable that the coal will run a little better than is indicated by the samples taken. The samples were cut from the roof to the floor and prepared in the usual way (see p. 104) for the laboratory.

Each sample was analyzed by F. M. Stanton, of the United States Geological Survey, by the standard methods adopted in that work. The analyses of these samples are given in the table on page 105.

PROSPECTIVE MINING CONDITIONS.

POSITION OF THE COAL MEASURES.

The coal in this field is known to outcrop from approximately sea level to elevations between 500 and 600 feet above the sea. Prospectors report higher outcrops on the mountains, where the elevations must be as much as 1,500 or 2,000 feet, and the structure in the range is such as to make the occurrence of these reported outcrops very probable. If the same seams of coal outcropping in the lower country extend to such elevations on the mountains, 
the quantity of coal in this field is much larger than has been estimated by the writer. The coal measures may possibly pass below Chignik Bay, but the amount of coal above sea level will probably supply the demand from this field for many years, and is certainly sufficient to encourage large mining enterprises.

DIP AND EXTENT OF THE COAL.

The coal seams in this field rest on the southeast flank of the main anticlinal fold of the Aleutian Range, and vary in dip from $21^{\circ}$ to $43^{\circ}$. From Chignik River the coal seam now being mined has been traced eastward for a little less than a mile. It is apparent from the exposures in Whalers Creek that coal is there continuous for about a mile, but the position and structure is such as to suggest that the coal seam in the Whalers Creek claim is the same as that exposed at the mine on Chignik River. The distance from Whalers Creek to Thompson Valley.is about 15 miles, but that portion of the field has not been examined. The exposures in Thompson Valley indicate that the coal is continuous over several square miles, and there is a strong suggestion that these coals may, when further work is done on them, be found essentially continuous with those to the southwest near Chignik River. The Hook Bay locality is about 8 miles from Thompson Valley, along the general strike of the coal measures. The exposures on the Hook Bay claims are reported to extend along the strike to the northeast for at least a mile, and detailed work may connect those seams with those already described. Still farther to the northeast, on the shores of Aniakchak Bay, coal is reported, but from verbal descriptions that coal appears to be lignite, and may prove of Kenai (Eocene) age rather than of Chignik (Upper Cretaceous) age. Small areas of the Kenai formation may be expected to occur at various places along the peninsula.

\section{SHIPMENT.}

The shipment of coal from the Chignik Bay field is somewhat difficult, because Chignik Bay and Chignik Lagoon do not offer good harbor facilities. Vessels of deep draft can not enter Chignik Lagoon, and there is no protection along the southwest side of Chignik Bay near the coal field. The cannery vessels receive their cargoes in Anchorage Bay, to which point the fish are brought in small boats or barges from the lagoon. A method of handling coal involving such transfers would be too expensive, and therefore a harbor must be sought to which coal can be brought directly from the mines. Hook Bay furnishes such a harbor for the northeastern portion of the field, and a railway could be constructed from Thompson Valley to Hook Bay without encountering any great engineering difficulties. The harbor most favorably considered by those now interested in this 
coal, however, is at the head of Kuiukta Bay, locally known as Dorenoi Bay. The entrance to this bay is a few miles southwest from Prospect Bay, which is shown in Plate VII (p. 40), but the head of Kuiukta Bay is only a little more than 5 miles from the shores of Chignik Lagoon. The pass from Chignik Lagoon to the head of Kuiukta Bay is through a broad, open valley, practically at sea level. It is proposed that a railroad be constructed from the coal field northwest of Chignik Lagoon to a narrow place in Chignik River, where a bridge may be built, and thence by way of the low pass to the head of Kuiukta Bay. A railroad could be constructed along the northwest side of Chignik Bay and Chignik Lagoon to receive the coal from the different portions of the field. The distance from the Chignik River coal mine to the head of Kuiukta Bay by the proposed route is about 9 miles. From Whalers Creek to Kuiukta Bay the railroad route would be about 15 miles. If Thompson Valley coal was carried by rail to Kuiukta Bay by way of a bridge across Chignik River, the haul would be between 30 and 35 miles. Kuiukta Bay was not visited by the writer, but the local boatman in the employ of the survey during the season of 1908 and the captain of the Dora, the one passenger vessel that regularly visits this coast, report the bay to have excellent harbor conditions near the head.

COAL HARBOR COAL FIELD.

GEOGRAPHY.

Unga Island is the largest and westernmost island of the Shumagin Group, which lies southeast of Balboa Bay. The greater portion of the island is mountainous, but the northern end has a rolling topography, its highest elevation being about 600 feet above sea level (Pl. II, p. 12). The northwestern portion of the island and a little strip along the west coast are known to contain the coal measures.

Unga Island has a milder and more equable climate than the mainland to the north. Practically all the winter snow disappears during the summer, and the number of clear days per year on the island exceeds the number for the mainland.

The northern portion of the island is overgrown by grasses and shrubs. A few patches of alder bushes are scattered on the valley slopes, but there are no trees.

There is a United States post office at Coal Harbor, and the passenger steamer which visits the coast calls at this port in each direction on its monthly voyages between Seward and points on the peninsula.

DEVELOPMENT WORK.

The development work that has been done in this field is described on page 19 of this report. A vertical section of the mine at Coal Harbor is given in figure 17. 


\section{AREAL EXTENT.}

The coal measures occupy an area of 35 or 40 square miles. This entire area may cortain coal similar to that exposed in the cliff at the east margin of the field, but no coal seams of ecomonic value were observed in the narrow strip along the west coast of the island.

GEOLOGY.

The coal measures in this field are of Eocene age and are a portion of the Kenai formation. The section is best exposed near the coal mine on the west shore of the Coal Harbor Inlet (fig. 14, p. 98). The formation rests in a slightly inclined position, and dips from $8^{\circ}$ to $10^{\circ}$. W. The general strike of the beds is N. $12^{\circ}$ W. The Kenai formation at

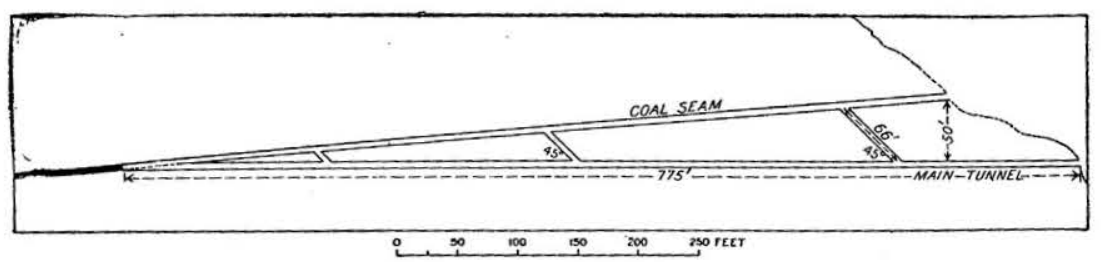

FIGURE 17,-Vertical section at Coal Harbor mine, Unga Island.

this locality is overlain conformably by the Unga conglomerate, which is of Miocene age (fig. 8, p. 66). The section measured on the cliff about one-half mile north of the coal mine is given below:

Section in upper Eocene and Miocene rocks at Coal Harbor, Unga Island.

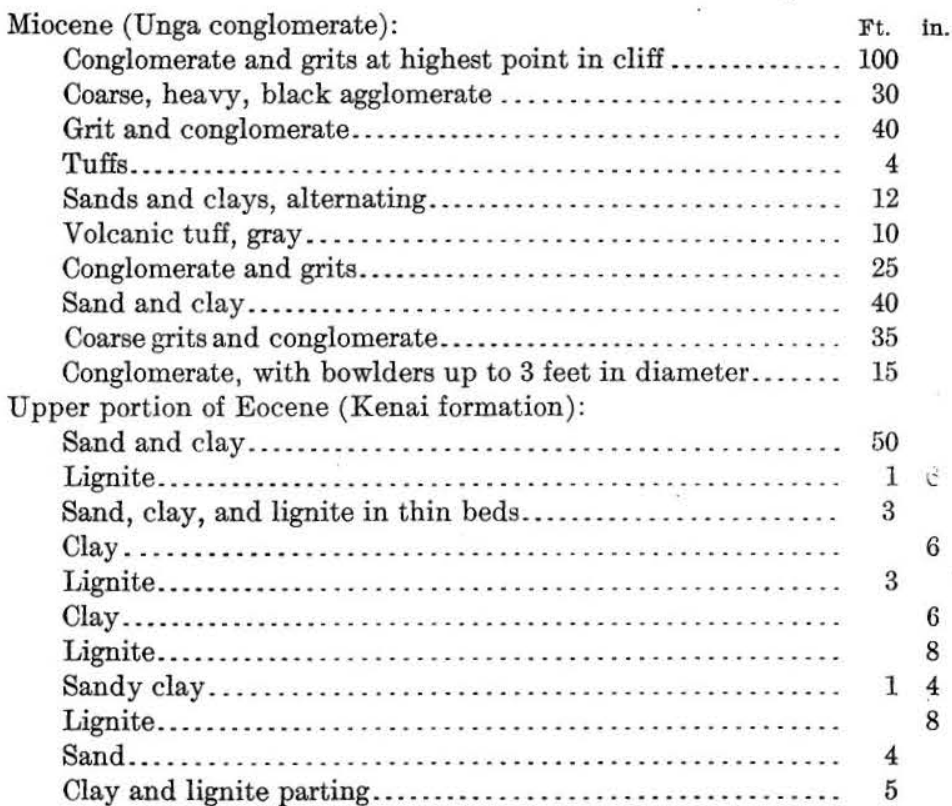




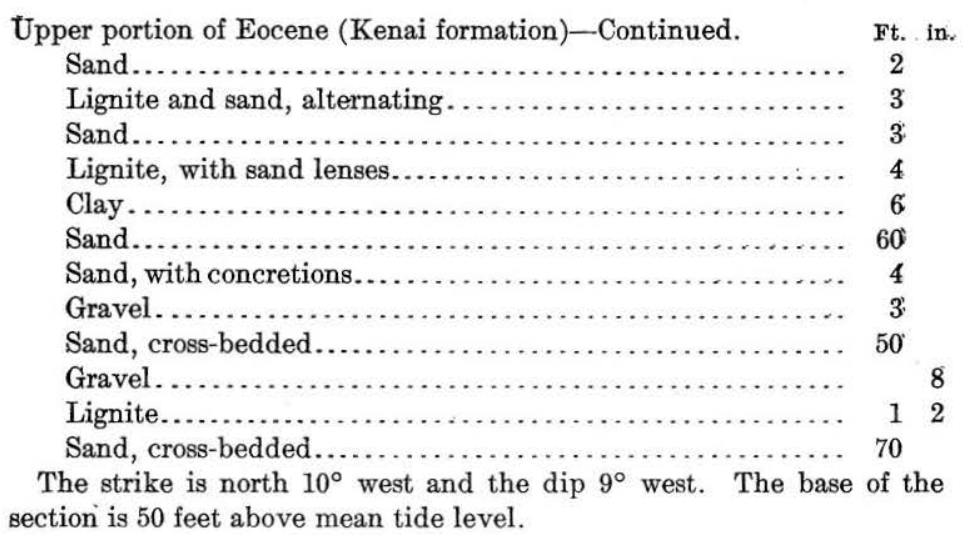

The coal measures, as is shown by the above section, are composed of sands, clays, gravels, and lignite, the materials being poorly cemented. No marine shells have been obtained from the coal measures, though the beds contain some plant remains, which have been described. (See p. 52.) The upper 200 feet in the measured section given above represents the Unga conglomerate at this locality. Shells of marine life have been secured from this formation, the beds of which consist chiefly of grits and conglomerates composed in part of volcanic materials.

\section{CHARACTER OF THE COAL.}

All the coal seen in this field is of lignitic character. The measured section indicates that, though seams are numerous, most of them are too thin to be of commercial value. The natives and white residents on the island and on some of the neighboring islands have prospected along certain of these thin seams and found some high-grade lignite in them, but the material does not occur in sufficient quantities to encourage development. The developed coal bed outcrops about 200 feet above tidewater. Detailed measurements of the upper part of the coal bed as now exposed in the mine are given in the following section:

Section of coal bed in Coal Harbor mine.

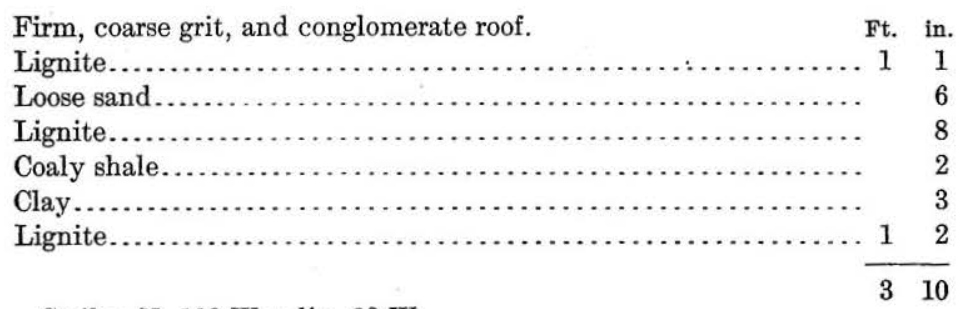

Strike, N. $12^{\circ}$ W.; dip, $8^{\circ}$ W. 
The bed was sampled in the usual way, the sand and shale, which could be readily separated in mining, being excluded. The analysis of the sample is given on page 105 .

\section{PROSPECTIVE MINING CONDITIONS.}

The Unga seams of lignite incline westward from an elevation of about 200 feet at the east margin of the field and evidently pass below sea level before reaching the western margin of the island. The quantity of lignite above sea level, however, is probably sufficient to supply the demand for such material from this field for a long time. The beds rest at so low an angle that mining can be done in a very inexpensive way.

There are no special difficulties associated with the mining or shipment of this lignite, and if it is mined with sufficient care to keep it clean it may be able to compete with the somewhat better coals that are now being shipped to this part of Alaska. This lignite will at least continue to be of value to the natives and to the few white people living on Unga and the neighboring islands. ${ }^{1}$

\section{PETROLEUM.}

COLD BAY OIL FIELD.

GEOGRAPHY.

Petroleum is known to occur in the vicinity of Cold Bay. This region was not visited by the writer, but it was examined by Martin ${ }^{2}$ during the summers of 1903 and 1904, and the following account is in part abstracted and in part quoted from his reports.

Cold Bay is located on the east side of the peninsula near the southern entrance to Shelikof Strait and about opposite the southwestern end of Kodiak Island. The bay is roughly triangular, about 10 miles long by 7 miles wide at the mouth, and contains a large area of deep water. It is a good harbor. (See Pl. VI, in pocket.) The surrounding country consists of an elevated upland with gently rounded or flat-topped hills rising above it, and its general level is about 750 feet above tide. The higher peaks rise to an elevation of about 1,500 feet, but farther back from the coast in the central part of the peninsula are mountains 5,000 feet or more in height. Among these is the volcano Peulik, a peak about 5,000 feet high, which is

\footnotetext{
1 G.C. Martin analyzed the problem of the markets for Alaskan coal and published his report in Bull. U. S. Geol. Survey No. 335, pp. 95-112.

2 Martin, G. C., Petroleum fields of the Pacific coast of Alaska: Bull. U. S. Geol. Survey No. 250, 1905, pp. 37-59; Notes on the petroleum fields of Alaska: Bull. U. S. Geol. Survey No. 259, pp. 133-138.
} 
situated on the western shore of the southern arm of Becharof Lake, about 35 miles west of Cold Bay. This volcano is one of the chain that extends the entire length of the Alaska Peninsula and throughout the Aleutian Islands.

Timber is entirely lacking in this region, the only trees being a few small cottonwoods, willows, and scrub alders along the banks of the streams. The flat lowlands along the shores of Cold Bay are covered with deep grass, but the hillsides and upland region have no vegetation except scattered tufts of grass and moss.

GEOLOGY.

STRATIGRAPHY.

A general section of the rocks exposed in the Cold Bay Becharof Lake region is given below. ${ }^{1}$

General section in the Cold Bay-Becharof Lake region.

\begin{tabular}{|c|c|c|c|}
\hline Name of formation. & Age. & Lithologic character. & $\begin{array}{c}\text { Thickness in } \\
\text { feet. }\end{array}$ \\
\hline & Post-Jurassic........... & Volcanic rock, probably andesite or & \\
\hline Naknek formation..... & Upper Jurassic........ & Arkose, conglomerate, sandstone, and & 3,000 to 5,000 \\
\hline "Enochkin formation". & $\begin{array}{l}\text { Middle Jurassic......... } \\
\text { Triassic.............. } \\
\text { Pre-Upper Jurassic.... }\end{array}$ & $\begin{array}{l}\text { Shale, sandstone, and a little limestone. } \\
\text { Shale, limestone, and chert............. } \\
\text { Granite, syenite, etc.................. }\end{array}$ & 2,000 \\
\hline
\end{tabular}

The coarse crystalline rocks (granite, syenite, and rocks of similar texture) occur in a belt that crosses the lower end of Becharof and Naknek lakes and possibly underlies the Cold Bay region.

Martin's report ${ }^{2}$ on the petroleum of the Cold Bay district is as follows:

The Triassic rocks occur on Cape Kekurnoi at the eastern entrance to Cold Bay, and on some of the capes and islands to the northeast. They doubtless underlie the Jurassic throughout the Cold Bay region.

The Enochkin formation occupies both shores of Cold Bay except at the northeastern promontory (Cape Kekurnoi) and at the head of the bay. It also extends in a belt along the shore of Shelikof Strait from Cold Bay to Dry Bay and probably as far beyond as Portage Bay.

The Naknek formation forms the shore of the head of Cold Bay and occupies the entire interior region as far west as Becharof Lake and as far north as Katmai.

The post-Jurassic volcanic rocks occur in a discontinuous belt near the center of the peninsula. This belt includes several volcanoes which have been active in comparatively recent time. The lavas are probably all either andesite or basalt.

1 From Bull. U. S. Geol. Survey No. 225, 1904, pp. 380-382; No. 250, 1905.

${ }^{2}$ Martin, G.C., Notes on the petroleum fields of Alaska: Bull. U. S. Geol. Survey No. 259, 1905, pp. $135-139$. 
STRUCTURE.

The most striking structural features are an anticline with a northeast-southwest axis extending from a point $3 \frac{1}{3}$ miles above the mouth of Oil Creek to Kanata and a syncline extending from near the mouth of Oil Creek northeastward into Cold Bay. The northern end of this syncline is cut off by a fault which extends up the valley of Dry Creek. The anticline terminates by flattening out.

The dip is quite uniformly northwestward on the north shore of Cold Bay and on the north side of Dry Creek. Along the southeastern side of Becharof Lake it is northwestward and westward. On the western shore of Cold Bay it is northwestward or horizontal. On Dry Bay it is southeastward. The dips seldom exceed $15^{\circ}$, except toward the mouth of the bay, and are low and regular over wide areas.

The region between Becharof Lake and the Becharof-Cold Bay divide has a uniform westward and northwestward dip. This dip is reversed again near the center of the peninsula, so that part of Becharof Lake lies in a syncline, while near its northwestern shore a sharp anticline is said to rise, which brings to the surface not only the entire sedimentary series, but also the mass of coarse crystalline rocks. There is also a great anticline parallel to the southern coast that has its axis near the ends of the forelands.

\section{INDICATIONS OF PETROLEUM.}

SEEPAGES.

There are several seepages at the north end of the anticline near the oil wells. In all of these the flow of petroleum is large and constant. One of them furnishes lubricating oil for use at the wells. There is also a considerable flow of gas at one of these seepages. Other seepages, not seen by the writer, are reported from various places along the crest of this same fold, near the head of Dry Bay, and elsewhere between that point and Kanata. There are said to be even more important seepages on the west shore of the south arm of Becharof Lake.

\section{DEVELOPMENTS.}

Three wells were begun in the summer of 1903 . They are located about 5 miles from the landing on the west shore of Cold Bay, at an elevation of about 750 feet above tide, and are distant about 9 miles in an air line from Becharof Lake.

One of the wells begun during the summer of 1903 was abandoned in the autumn at a depth of several hundred feet, and the derrick was moved to a new site a few hundred feet distant. Very little drilling had been done at this point up to the time the writer left Alaska.

The second well was drilled to a depth of about 1,400 feet. The drill is said to have penetrated several strata filled with thick residual oil having about the consistency of warm pitch. This well was finally abandoned during the summer of 1904 because of the strong, continual flow of fresh water. It is now certain that this well is situated near a fault, which fact would seem to explain the presence of large amounts of fresh water at all depths, and also the absence of the more volatile and fluid constituents in the oil. The machinery from this well has now been moved to a new location about $2 \frac{1}{4}$ miles southeastward, on Trail Creek. At last reports it had reached a depth of 1,500 feet. 
Record of well at Cold Bay.

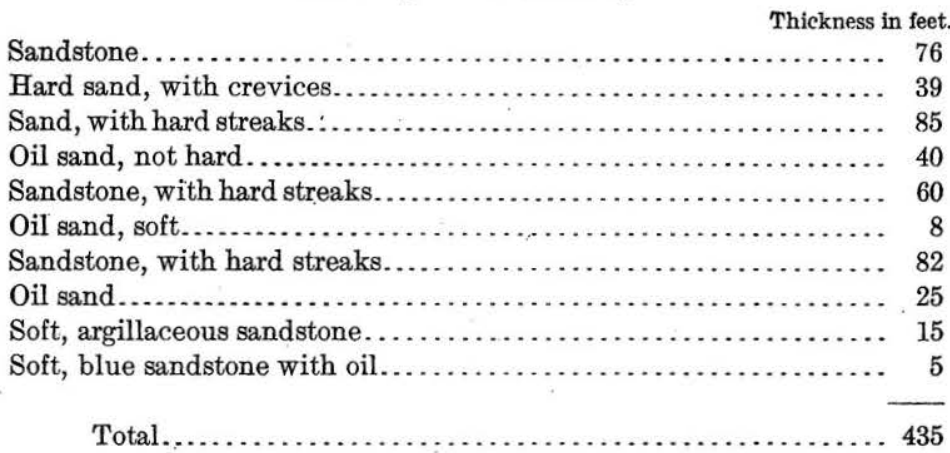

CHARACTER OF THE OIL.

Samples of the oil from Cold Bay have been collected by the writer. They were obtained by skimming the petroleum from the surface of the pools of water where it was continually rising from the bottom of the pool. An effort was made to obtain as much of the fresher oil as possible. Vegetable and earthy impurities were removed by straining through coarse cloth. Water could not be entirely removed. Oil for lubricating purposes at the neighboring wells is obtained from these pools in this manner.

The fresher oil is dark green. That which has remained on the surface of the pool for some time is dark brown.

The oil has doubtless lost a large part of its volatile constituents. The analyses, therefore, would not correctly represent the composition of live oil from wells in this region. Such oil would have a lower specific gravity, higher percentage of the more volatile constituents, and lower percentage of the less volatile constituents, residue, and sulphur. It would certainly be better than these samples in all respects, and would resemble them in having a paraffin base. It might not be of as high quality as the Controller Bay petroleum, but nevertheless it would be a refining oil.

The samples were submitted to Penniman \& Browne, of Baltimore, who return the following report on their tests:

\section{Report of tests of oil from Cold Bay.}

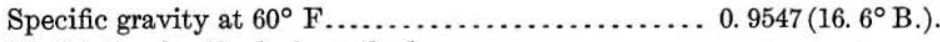

Distillation by Engler's method:

Initial boiling point.................... ${ }^{\circ} \mathrm{C} . .225$.

Burning oil (distillation up to $300^{\circ} \mathrm{C}$., under atmospheric pressure $). \ldots \ldots \ldots \ldots \ldots$........ per cent.. $13.3\left(29.6^{\circ}\right.$ B.).

Lubricating oils (spindle oils) (120 mm. pressure up to $300^{\circ}$ C.) ......................... per cent.. $28.3\left(23.8^{\circ}\right.$ B.).

Lubricating oils $\left(120 \mathrm{~mm}\right.$. pressure, $300^{\circ}$ C.$350^{\circ}$ C.)............................... 18.3 (18 cent. B.).

Paraffin oils (by destructive distillation under atmospheric pressure................... per cent.. 32.0 (20. $4^{\circ}$ B.).

Coke and loss................................. 8.1.

Total sulphur............................. 0.116 .

"The distillation of the lubricating oils under diminished pressure, corresponding to refinery practice, was carried on until signs of decomposition set in. The resulting residue was unsuitable for making cylinder stock, and was therefore distilled for 
paraffin oils. These paraffin oils contain a considerable quantity of solid paraffin. It was not practicable to determine the amount of the material with the small amount of oil at our disposal.

"The iodine absorption of the oils and distillates has been determined by Hanus's method (solution standing four hours) and the results are here tabulated:

Iodine absorption of oils and distillates.

\begin{tabular}{|c|c|c|}
\hline . & 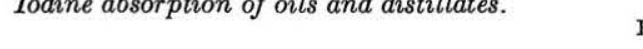 & Per cent. \\
\hline Burning oil....... & 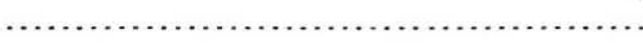 & . 17.2 \\
\hline $\begin{array}{l}\text { Lubricating oil.. } \\
\text { Heavy lubricatin }\end{array}$ & ng & $\begin{array}{l}27.2 \\
35.2\end{array}$ \\
\hline
\end{tabular}

"These iodine numbers upon the lubricating oils were obtained upon the samples. For comparison, samples of similar oils were obtained from the Standard Oil Co. and the iodine numbers determined as follows:

Light distillated lubricating oil (spindle oil)................. 32 per cent iodine.

Dark lubricating oil (engine oil)....................... 45.4 per cent iodine.

"The burning oils were tested in a small lamp and found to give a good flame. All the oil was consumed without incrusting the wick or corroding the burner.

"The sample of crude oil from Cold Bay was distilled in such a way as to give the maximum yield of burning oil. Under these conditions 52.2 per cent of fair quality burning oil was obtained.

"The oils have paraffin bases, and the products of distillation are 'sweet.' We are informed that these samples are 'seepage oils.' If a sufficient yield can be obtained by drilling, a very suitable oil for refinery purposes may be expected, containing a very much larger quantity of the more desirable lighter products."

\section{OTHER POSSIBLE PETROLEUM FIELDS.}

A well at Dry Bay was drilled to a depth of 320 feet in the summer of 1902 without encountering oil. The tools were then lost and the hole was abandoned. In August, 1903, a new well was started in close proximity to the first, but not much was accomplished, and work was discontinued a few months later because of an accident to the machinery. Martin ${ }^{1}$ says of other possible prospects:

Seepages are reported from the shores of Kamishak Bay, especially at Douglas River. The rocks in this region are shales, sandstones, and conglomerates of Jurassic age. They are the equivalent in age of the beds overlying the Enochkin formation in the region to the north already described. The rocks are here horizontal or have very gentle dips over large areas, and it would seem to be a promising region to prospect with the drill. If the Middle and Lower Jurassic rocks in the Enochkin or Cold Bay regions prove to contain oil in commercial quantity, it would seem that new fields might reasonably be expected on the coast at Douglas River and for 20 miles westward. This is, however, a difficult place to land machinery, for the bays are all shallow and filled with rocks, while numerous uncharted reefs extend out many miles from shore into Cook Inlet. The writer is, therefore, not inclined to encourage speculation here, at least until more encouraging news is received.

The geology of the coast between Douglas River and Katmai does not warrant in the slightest degree any petroleum prospecting. Along much of this coast are only volcanic and other crystalline rocks, in which the occurrence of petroleum is an absolute impossibility.

\footnotetext{
1 Martin, G. C., Notes on the petroleum flelds of Alaska; Bull. U. S. Geol. Survey No. 259, 1905, pp. 135-
} 139. 
GOLD.

POPOF ISLAND.

Placer gold was discovered by Louis Herman in the beach about $1 \frac{1}{2}$ miles south of Sand Point post office on Popof Island in the summer of 1904. (See Pl. VIII, p. 42.) Active work was in progress during 1904 and 1905, and it is reported that gold amounting in value to about $\$ 12,000$ was taken from these beach placers in those years. The productive belt was about three-fourths of a mile long. From 20 to 40 men were at work during the summer of 1904 with rockers, washing the coarse sand and gravel. All the gold was found below mid-tide, and most of it around large bowlders at about the level of low tide. Little work has been done on this beach since 1905. In 1908 but one man was engaged in rewashing the sand and gravel, and he is reported to have found it unprofitable and finally to have abandoned operations.

During 1908, most of the interest on this island was centered on four lode claims that were staked on the hills immediately adjoining the beach placers. No distinct quartz ledges have been located, but the exposed rock contains some free gold. Specimens in which free gold is plainly visible may be found in the surface zone of oxidation and weathering. This zone varies from 5 to 10 feet in thickness. Several samples taken from the weathered material yielded some free gold when crushed and panned. The owners of this property have had several samples assayed, and values up to $\$ 20$ a ton were reported as a result of the assays. On the Louis Herman property a short tunnel has been driven and four shafts have been sunk below the zone of surface weathering. Ore samples taken from three openings on this property varied greatly in content of gold; one sample was exceedingly rich. The rock in which this gold occurs is an andesite similar to that in Unga Island, where the Apollo mine is located. The unweathered rock appears as a light gray lava, containing an abundance of small pyrite crystals. In claim adjoining the Louis Herman property one small quartz ledge has been discovered and some development work has been done.

UNGA ISLAND.

Gold-bearing ledges have been found at a number of places in Unga Island. (See Pl. VIII, p. 42.) In the southeastern portion of the island, about 1 mile from the head of Delarof Harbor and 4 miles from the town of Unga, are located the Apollo and Sitka mines. A third mine has been opened on the Shumagin group of claims, near the head of Baralof or Squaw Harbor. Several locations for gold lodes have been made on the ridge south of the Apollo mine, in 
the valley west of the Shumagin mine, and at points about 2 miles south of Coal Harbor.

Apollo Consolidated mine.-This mine was on a productive basis from 1891 to 1904 and was reopened during the summer of 1908, when 40 of the 60 stamps in the mill were put into operation and ore that had already been mined was run through the mill. The occurrence of gold ore at this locality has been described by Becker ${ }^{1}$ and by Martin, ${ }^{2}$ who visited it in 1904, gathering some additional data.

The deposit, according to Becker's description, is a reticulated vein or zone of fracture, in a country rock of andesite and dacite. The ores include free gold, pyrite, galena, zinc blende, copper pyrite, and native copper. The ore is free milling, a large part of the gold being carried in the native state. The chief gangue mineral is quartz, but calcite and orthoclase are present in subordinate amounts. The ore body strikes N. $20^{\circ} \mathrm{E}$. It is from 5 to 40 feet wide and forms a chute that pitches northward. The chute comes to the surface at the south end of the workings at an elevation of 600 feet, and at the north end it narrows and becomes of low grade at a depth of about 800 feet. Several attempts have been made to reach the ore body at lower levels by shaft and tunnel, and long crosscut tunnels have been driven in prospecting the adjoining areas. In places the ore body was exceedingly rich, carrying up to $\$ 50$ a ton; the average for the main ore body was perhaps about $\$ 8$ a ton. The main chute has not been worked out. Some ore has been taken from minor zones of fracture in the crosscut tunnels, but ore has not been found in these zones in sufficient quantities to justify a continuation of the work. The country rock has been mineralized to a certain extent on either side of the main ore body.

Becker concluded that the country rock is Miocene or post-Miocene, because of its lithologic similarity to andesite, which is supposed to overlie the Miocene at the north end of the island. $\mathrm{He}$ would, accordingly, make the mineral veins of very recent Tertiary or post-Tertiary age. The present writer believes the post-Miocene andesites at the north end of Unga Island to be distinct in age from the country rock in which the gold ledges occur. The younger andesites cover a portion of the south end of the island and overlie irregularly the gold-bearing formation. The age of the rock in which the gold-bearing ledges occur is not definitely known, but it is believed by the writer to be Mesozoic or older.

Sitka mine.-This mine is located north of the Apollo mine across the valley. The ore body is associated with a sheer zone which strikes at right angles to the Apollo ore body. The rock in which

Becker, G. F., Reconnaissance of the gold fields of southern Alaska: Eighteenth Ann. Rept. U. S. Geol. Survey, pt. 3,1898 , pp. 12, 83-85.

¿Martin, G. C., Gold deposits of the Shumagin Islands: Bull. U. S. Geol. Survey No. 259, 1905, pp. 100-101. 
this ore occurs is of the same general type as that at the Apollo mine; the ores consist of free gold, galena, zinc blende, and pyrite, and the chief gangue mineral is quartz, with subordinate amounts of calcite. The ore, however, is of low grade, and has never yet paid for the working. Some of the material in the dump was run through the mill during the summer of 1908 . The superintendent believes that the ore could now be mined and milled at a profit. This mine is connected by a tramway with the Apollo plant, so that the ore may be handled at the Apollo mill.

Shumagin mine.-The Shumagin claims have been staked out along two ledges which strike N. $60^{\circ} \mathrm{E}$. and outcrop in a low ridge one-half mile southwest of the head of Baranof Harbor. The southern ledge is about 50 feet thick, but the ore has not proved sufficiently rich to encourage mining. The other ledge, which varies in width from 2 to 3 feet, is reported to carry values commonly ranging between $\$ 4$ and $\$ 5$ to the ton, and nowhere running below $\$ 2$. These quartz ledges are in shear zones, and are interrupted by many horses of country rock. The present workings consist of two tunnels, with crosscuts. The lower tunnel, which has been driven 363 feet, passes through the wider quartz ledge, and within a short distance of the second ledge. A crosscut 75 feet long has been made at the end of this tunnel. The upper tunnel is 79 feet long, and a crosscut at the end runs 116 feet to the east and 53 feet to the west along the ore body. The two tunnels are separated in elevation by 150 feet.

\section{UNALASKA ISLAND.}

The island of Unalaska is off the western extremity of Alaska Peninsula, near one of the most frequented routes from the Pacific Ocean to Bering Sea. It is important chiefly on account of its splendid natural harbor, on which are located two coaling and trade stations, Dutch Harbor and Unalaska. Several years ago an unsuccessful attempt was made to develop and mine some gold-bearing quartz veins near the village of Unalaska. A 3-stamp mill and a couple of tramways to connect the mill with the mines were erected, but these are now in a state of ruin. Quartz veins of economic value are reported by prospectors on several of the islands farther west.

The following notes are quoted from a report on this district, made in 1905 by Collier: ${ }^{1}$

The hard rocks of the islands are volcanic and consist of interbedded tuffs and flow that are cut by numerous dikes. The most common rocks are dark-gray andesites. ${ }^{2}$

South of Dutch Harbor for several miles the rocks are cut by a system of nearly vertical joint planes which extend approximately east and west. Mineralization

1 Collier, A. J., Auriferous quartz veins on Unalaska Island: Bull. U. S. Geol. Survey No. 259, 1905, pp. 102-103.

2 Emerson, B. K., Harriman Alimąa Expedition, vol. 6, Geology, 1904, p. 29. 
has occurred along these joints, and in some instances quartz veins have been formed. Several such quartz veins are exposed in the bluff west of Unalaska, where they have been prospected by short tunnels. The best example, however, is found at the gold mine located $1 \frac{1}{2}$ miles south of Unalaska and about a quarter of a mile from the shore of Captains Bay, where a number of small veins of this kind are contained in compact gray andesite. The largest of these forms the main ore body of the mine and has been opened for about 200 feet. It has a maximum width of 6 or 7 feet, but thins out in both directions from the widest part and at the ends of the tunnels is not over 1 or 2 feet wide. The samples obtained here consist of kaolin and cellular quartz, heavily stained with iron in the form of limonite. Samples obtained on the dump and around the mill indicate that a considerable portion of the ore originally contained unweathered pyrite and sulphide minerals. A sample taken by the writer from the face of the drift at the principal ore body was assayed by E. E. Burlingame \& Co., of Denver, who reported 0.02 ounces of gold to the ton and a trace of silver. It is reported that before the mill was built assays promised very high values, which were not realized from the ore when milled.

\section{GOLD PROSPECTS ON THE PENINSULA.}

Locations for gold have been made at the head of Port Moller (Pl. VIII, p. 42) and on the shores of Mallard Duck Bay (Pl. VII, p. 40). The locations at the head of Port Moller are in basaltic lava, where the rock has been so altered as to present a brilliant yellow color. The exposure is strikingly conspicuous as far away as it can be seen. Most of the brilliantly colored rock had been staked out by the close of 1908 , but no development work had been done. The samples taken by the writer proved to have a little gold in them.

The description ${ }^{1}$ of the microscopical characters of this rock is given below:

Basalt.-This proves to be a highly porphyritic rock in which the phenocrysts form more than half the bulk of the section. There are numerous glassy labradorite phenocrysts and sporadic large augites embedded in a mesostasis consisting of granular augite, plagioclase microlites, and magnetite. The augite is altered and pseudomorphosed by a pleochroic reddish-yellow (iddingsite-like?) alteration product. This substance forms in the feldspar also to some extent. In one case it appears to have been derived from olivine.

The claims along the shores of Mallard Duck Bay are in mineralized crushed zones in an andesitic lava. These zones contain galenite, sphalerite, pyrite, and a large amount of quartz. The wall rock carries a noticeable amount of pyrite. The exposures seen in 1908 were scarcely below the surface soil. The most richly mineralized zone seen is on the southwest side of the bay near the head. This zone is from 4 to 6 feet wide and appears to have a linear extent of at least 100 feet. A mantle of glacial drift made it impossible to trace the zone farther without doing some prospecting work. 


\section{COPPER.}

No copper mines have been opened up in southwestern Alaska, but several locations have been made for copper at Prospect Bay and on the east shore of Balboa Bay.

\section{PROSPECT BAY.}

Prospect Bay is a few miles west of Chignik Bay, on the south shore of Alaska Peninsula. (See Pl. VII, p. 40.) The copper property here has attracted some attention, and various reports regarding it have appeared in Alaskan and Pacific coast papers. The ore body is located at the west shore near the head of Prospect Bay, and fortunately near an excellent little harbor behind a sand and gravel hook. (Fig. 18.) The zone that has been staked is about 50 feet wide. It is a crushed zone, and in the fissures the minerals, which include pyrite, galena, sphalerite, chalcopyrite, and quartz, are in the crystalline form, the crystalline development being in places of the geode type. When these claims were visited during the early part of the 1908 season no large body of high grade ore had been developed, as was currently reported. Hand specimens fairly rich in copper minerals may be procured from the fracture cavities.

\section{BALBOA BAY.}

Some copper occurs in a shear zone on the east shore

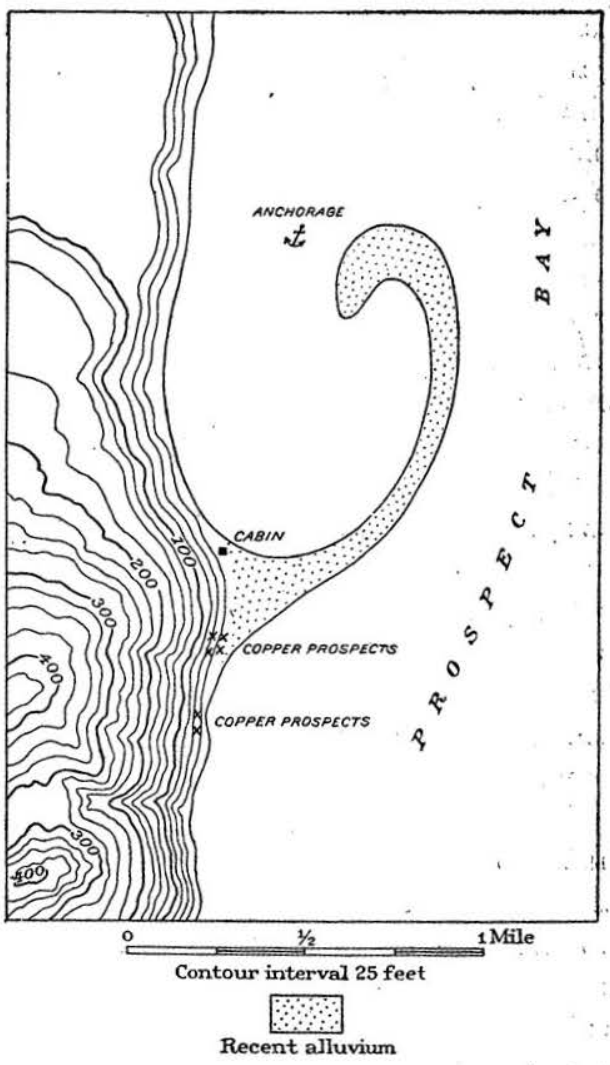

Frgure 18.-Sketch map of a portion of Prospect Bay, showing the form of the harbor and the location: of copper prospects.

of Balboa Bay, in the midst of the andesitic lava. There are several prospects in this vicinity, and one short tunnel was driven some years ago, but the claims have now been entirely abandoned.

$$
90054^{\circ}-\text { Bull. } 467-11-9
$$




\section{SUGGESTIONS TO PROSPECTORS}

The period of active prospecting on the peninsula will probably be limited during most years to the months of June, July, August, and September. The heavy winter snowfall remains nearly to sea level until late in May or early in June, and since fresh snows of the succeeding winter begin to accumulate by the early part of September, by the close of that month little surface work could profitably be done. The period of prospecting on the islands would be somewhat longer than on the mainland.

The formations are excellently exposed along the Pacific coast and through the central part of the peninsula on the flanks of the mountains and on the canyon walls. The Pacific coast may, when proper care and patience are exercised, be visited in small boats, and from the heads of bays the central portion of the peninsula is at many places easily accessible. The Bristol Bay side of the peninsula will prove less attractive to prospectors, for the neighboring waters are exceedingly shallow and the area adjoining the coast is a tundra covered lowland. Boats may move readily into the central portion of the peninsula at Port Moller and at Port Heiden. Small boats may be taken up the rivers to the large lakes in the northwestern portion of the peninsula. Prospecting could probably be easily conducted from the shores of these lakes.

The formation known to contain workable coal is of Upper Cretaceous age, and has been described as the Chignik formation. This formation, which is found near the head of Herendeen Bay, northwest of Chignik Bay, and at Douglas village, near the northeastern extremity of the peninsula, is probably much more extensive than is now positively known. It is somewhat safe to infer that it extends northeastward from Chignik Bay for many miles, and as coal has been reported on the northwest slope of the Aleutian Range east of Chignik Lake, it is quite possible that the main coal-bearing formation may soutcrop on that side of the peninsula. The structure is anticlinal, and consequently the Chignil formation may be expected near the northwest base of the range. It may also be found in the territory between Chignik Bay and Port Moller, though in this region Tertiary sediments and Recent volcanic rocks may mantle or obscure the formation. The Douglas locality of the Chignik formation is not known to contain coal.

The formation which overlies the Chignik is of Eocene age, and is known as the Kenai formation. It contains seams of lignite, which have in places been worked for local markets. Reference to Plate VI (in pocket) will show that this formation is very extensive, and it is probably much more extensive than is yet known. At no place in the peninsula, however, has coal been found in the Kenai formation of such quality as to encourage expensive development work or 
any large investment. The coal reported west of Herendeen Bay on the northwest side of the peninsula is probably of Kenai (Eocene) age.

The gold veins which have been profitably worked in this portion of Alaska occur in andesitic rocks believed to be of early Tertiary age. No metalliferous ores have been found. in or in association with the sedimentary rocks or recent volcanics in the peninsula. The known extent of these andesitic rocks is shown on Plates VII (p. 40) and VIII (p. 42), but they will doubtless be found to be much more extensive. They have commonly been so altered by metamorphic processes that they may be detected by their brilliant red and yellow colors. The gold-bearing quartz veins which have been thus far located are not in the most highly colored portions of this group of rocks, but the colors may guide the prospector in the unsurveyed portions of the field to areas where time may be more profitably spent. The rock bearing the quartz veins is commonly rich in pyrite, and the weathering of this mineral accounts in part for the brilliant colors referred to.

The single instance of placer gold on the shore of Popof Island occurs on the beach near certain of the older Popof lavas, where the waves have broken and worked the gold-bearing rock of the island to a beach gravel. Locations for gold have been made at the head of Port Moller, but samples taken from that locality have not shown large values. Near the head of Mallard Duck Bay, an arm of Chignik Lagoon, the andesitic lavas, which might profitably be prospected, outcrop, and there are indications of mineralization in certain of the shear zones near the beach. All the gold-bearing quartz lodes that have been profitably worked occur in association with crushed zones. The minerals occurring in association with gold are galenite, sphalerite, pyrite, and quartz. Prospecting should, therefore, be most actively prosecuted in the areas indicated on the maps (Pls. VII and VIII) accompanying this report as containing "andesites with associated tuffs and breccias," and in the extension of such areas in the unsurveyed portions of the peninsula and the neighboring islands.

The copper which has been located on the peninsula occurs in association with a shear zone in andesitic lava. Though detailed work has not been done around Prospect Bay where these copper locations have been made, yet it is believed that the rocks there belong to the same group in which the gold-bearing lodes have been found. It is not unlikely that a zone or belt of these earlier Tertiary lavas and volcanic rocks border the coast from Prospect Bay westward to the vicinity of Stepovak Bay, and that belt might profitably be prospected for gold and copper.

Suggestions bearing on the petroleum in the peninsula and the prospecting for other oil fields have been made on page 124 . 


\section{BIBLIOGRAPHY.}

The following is a list of the publications consulted in the preparation of this report that contain references to the geology, paleontology, and mineral resources of Alaska Peninsula and the neighboring islands:

Atwood, Wallace W., Mineral resources of southwestern Alaska: Bull. U. S. Geol. Survey No. 379, 1909, pp. 108-152.

Becker, George F., Reconnaissance of the gold fields of southern Alaska: Eighteenth Ann. Rept. U. S. Geol. Survey, pt. 3, 1898, pp. 83-85.

- Distribution of gold deposits in Alaska: Jour. Geology, vol. 3, pp. 960-962.

Brooks, Alfred H., The coal resources of Alaska: Twenty-second Ann. Rept. U. S. Geol. Survey, pt. 3, 1902, pp. 543-555.

- The geography of Alaska, with an outline of the geomorphology: Eighth Rept.

Intern. Geog. Cong., 1905, pp. 204-230, 1 map.

The geography and geology of Alaska: Prof. Paper U. S. Geol. Survey No. 45, 1906.

The outlook for coal mining in Alaska: Trans. Am. Inst. Min. Eng., Bimonthly Bull. No. 4, 1905, pp. 683-602.

Collier, A. J., Auriferous quartz veins on Unalaska Island: Bull. U. S. Geol. Survey No. 259, 1905, pp. 102-103.

DaLL, W. H., Report on coal and lignite of Alaska: Seventeenth Ann. Rept. U. S. Geol. Survey, pt. 1, 1896, pp. 856-869.

Correlation papers-Neocene: Bull. U. S. Geol. Survey No. 84, 1892, pp. 240-242.

- Neozoic invertebrate fossils: Harriman Alaska Expedition, vol. 4, 1904, pp. 99-122, 2 pls.

Dawson, George M., Geological notes on some of the coasts and islands of the Bering Sea and vicinity: Bull. Geol. Soc. America, vol. 5, 1894, pp. 117-146.

EICHWALD, E. von, Geognostisch-palæontologische Bemerkungen über die Halbinsel Mangischlak und die Aleutischen Inseln. St. Petersburg, 1871, pp. 88-200.

Frscher, PAuL, Sur quelques fossils de l'Alaska, in Voyage à la côte nordouest de l'Amérique, 1870-1872, par Alphonse Pinart. Paris, 1875, pp. 3336.

Gannetr, Henry, Geography of Alaska: Harriman Alaska Expedition, vol. 2, 1902, pp. 257-277.

GRewINGK, G., Beiträge zur Kenntniss der orographischen und geognostischen Beschaffenheit der Nordwest Küste Amerikas mit den anliegenden Inseln: Verhandl. Russ. Kais. Min. Gesellsch. St. Petersburg, Jahrg. 1848-49 (1850), pp. 121, 344-347.

Hyatt, Alpheus, Report on the Mesozoic fossils: Seventeenth Ann. Rept. U. S. Geol. Survey, pt. 1, Appendix 3, pp. 907-908.

Knowlton, Frank Hall, Fossil flora of Alaska: Bull. Geol. Soc. America, vol. 5, 1893, pp. 573-590.

- Review of fossil flora of Alaska, with descriptions of new species: Proc. U. S. Nat. Mus., vol. 17, 1895, pp. 207-240. 
Knowiton, Frank HaLl, Report on the fossil plants collected in Alaska in 1895, as well as an enumeration of those previously known from the same region, with a table showing their relative distribution: Seventeenth Ann. Rept. U. S. Geol. Survey, pt. 1, 1906, Appendix 1, pp. 876-897.

Fossil plants from Kukak Bay, Alaska: Harriman Alaska Expedition, vol. 4, 1904, pp. 149-162, 12 pls.

Martin, G. C., Petroleum fields of Alaska and the Bering River coal fields: Bull. U. S. Geol. Survey No. 225, 1904, pp. 376-381.

- The petroleum fields of the Pacific coast of Alaska, with an account of the Bering River coal deposits: Bull. U. S .Geol. Survey No. 250, 1905, 64 pp.

-Gold deposits of the Shumagin Islands: Bull. U. S. Geol. Survey No. 259, 1905, pp: 100-101.

- Notes on the petroleum fields of Alaska: Bull. U. S. Geol. Survey No. 259, 1905, pp. 128-139. See also Stanton and Martin.

Neumayr, M., Die geographische Verbreitung der Jura-formation: Denkschr. Wiener Akad., Bd. 50, 1885, pp. 93-94.

Oliphant, F. H., Mineral resources in U. S.-Petroleum: Nineteenth Ann. Rept. U. S. Geol. Survey, pt. 6, 1897, p. 110.

Paige, Sidney, The Herendeen Bay coal field: Bull. U. S. Geol. Survey No. 284, 1906, pp. 101-10s.

Palache, Charles, Geology about Chichagof Cove, Stepovak Bay, with notes on Popof and Unga Islands: Harriman Alaska Expedition, vol. 4, 1904, pp. 69-88.

Notes on minerals collected by Harriman Alaska Expedition: Harriman Alaska Expedition, vol. 4; 1904, pp. 91-96.

PoмpeckJ, J. F., Jura-Fossilien aus Alaska: Verhandl. Kais. Russ. Min. Gesellsch., 2d ser., vol. 38, St. Petersburg, 1900, pp. 239-282, pls. 5-7.

Stanton, T. W., and Martin, G. C., Mesozoic section on Cook Inlet and Alaska Peninsula: Bull. Geol. Soc. America, vol. 16, 1905, pp. 391-410, 4 pls., 2 figs.

SpurR, J. E., Reconnaissance in southwestern Alaska in 1898: Twentieth Ann. Rept. U. S. Geol. Survey, pt. 7, 1900, pp. 43-263.

Stone, Ralph W., Coal resources of southwesteru Alaska: Bull. U. S. Geol. Survey No. 259, 1905, pp. 151-171.

WARD, Lester F., Geographical distribution of plants; Literature of fossil plants of Alaska: Eighth Ann. Rept. U. S. Geol. Survey, pt. 2, 1886-87, pp. 924-926.

White, Charles A., On a small collection of Mesozoic fossils collected in Alaska by Mr. W. H. Dall: Bull. U. S. Geol. Survey No. 4, 1884, pp. 10-16.

Correlation papers-Cretaceous: Bull. U. S. Geol. Survey No. 82, 1891, pp. 205-206.

- Mesozoic Mollusca of the southern coast of the Alaska Peninsula: Bull. U. S. Genl. Survey No. 51, 1889, pp. 64-70. 



\section{INDEX.}

A. Page.

Acknowledgments....................... 12-13 Alaska Peninsula, American explorations of . 11-12 animals of .............................. 21 climate of ............................ 15-17 coasts of ............................. 14-15 commercial development of............ 19-21 drainage of ............................ 15 early explorations of................... 9-11 general geology of $. \ldots \ldots \ldots \ldots \ldots \ldots \ldots .23-30$ location and extent of.................. 9 lowlands of ............................ 14 map showing ..................... In pocket. mountains of.......................... 13 settlement of ......................... 18 stratigraphy of ................. 23-25, 29-30 structure sections across, figures showing 28,59 transportation in.

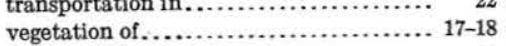

Alaska, southwestern, map showing........ 10

Aleutian Mountains, description of.......... 13 formation of ......................... 83 growth of............................ 82 Alluvium, character and occurrence of....... 75-76 Anchorage Bay, view of, plate showing...... $\quad 86$ Animals of Alaska Peninsula............... 21 Apollo Consolidated mine, description of.... 21,126 Argillite, occurrence of ................... 30 Augite porphyry, occurrence of............. 63

B.

Balboa Bay, deposits of copper at.......... $\quad 129$ Miocene sediments near................ 67 shore features near, figure showing....... 107

Balboa Bay region, maps showing ......... 12,42 stratigraphy of ....................... 29

Baralof Harbor, shore features near, figures showing ..................... 93,94

Becker, G. F., work of, on the gold fields of southern Alaska................. 11

Bering, Vitus, voyage of................... 9-10

Bibliography........................... 132-133

Brooks, Alfred H., preface by.............. 7

\section{C.}

Cape Douglas. See Douglas, Cape. Cathedral Peak, plate showing................
Caves on Unga Island, view of, plate showing. Chichagof Peak, diagrammatic section of..... Chignik Bay coal field, developments at..... Chignik Bay region, map showing............ stratigraphy of.
Page. 4 formation, character or................ 41-43 fauna and flora of .................... 43-47 stratigraphy of ....................... $47-48$ Chignik River, coal bed on, description of.. 110-111 Climate of Alaska Peninsula................ 15-17 Coal, Chignik Bay, chemical properties of .. 105,115 Chignik Bay, physical properties of.... 114-115 Coal Harbor, physical and chemical properties of . ................ 105,119-120

Herendeen Bay, chemical properties of 103-104 physical properties of............. 104-105 prospective conditions of mining... 106,115, 120 shipment of, from Chignik Bay field... 116-117 from Herendeen Bay field......... 107-108 suggestions to prospectors for........... 130 Coal field, Chignik Bay, developments at.... 20 Chignik Bay, geology of................ 109-110 location of ...................... 108-109 position of beds of ............... 110-114

Coal Harbor, Unga Island, description of ............................ 117-119

Herendeen Bay, areal extent of.......... 97 columnar section of, figure showing.. 98 description of...................... 96 developments at.................... 19-20 geology of ..................... 97-100 location of........................ 96-97 stratigraphy of.................. 97-98 sections in....................... 100-103 structure of........................ 98-100 structure section of, figure showing.. $\quad 97$

Unga Island, developments at.......... 19 Coal Harbor mine, vertical section at, figure showing...................... 118

Coal measures, Chignik Bay, extent of....... 116

Chignik Bay, position of.............. 115-116

Herendeen Bay, extent of ............. 107 position of......................... 106

section of, figure showing ............... 99 Coal mines, entrances to, views of, plate showing............................. 110

Coastal features of the region............... 14-15

Cold Bay, oil field at.................... 120-121

Collier, A. J., on gold deposits of Unalaska Island...................... 127-128

work of, on the geology of Alaska Peninsula............................ 12

Commercial development of the region...... 19-2

Cook, Capt. James, exploration by.......... 10

Copper, occurrence of, on Alaska Peninsula.. 21

prospects of, location of.................. 129

suggestions to prospectors for........... 131

Cretaceous. See Lower Cretaceous and Upper Cretaceous. 
D.

Dacites, occurrence of.

Dall, W. H., acknowledgments to ..

on fauna of Kenai formation . . .......... 55-56

on Unga conglomerate.

work of, on the geology of Alaska........

Diorite porphyrite, occurrence of..............

Dora, SS., officers of, acknowledgments to...

Douglas, Cape, geologic sketch map of ........ view ol, plate showing...................

Drainage of the region......................

Drift, glacial, occurrence of..................

$\mathrm{E}$.

Eakin, H. M., work of, on the geology of Alaska Peninsula...............

Emerson, B. K., work of, on geology of Alaska Peninsula....................

Enochkin formation, occurrence of........ 25,32-33

Eocene, early, time, volcanic rocks of, description of ................... 48-49

late, or early Miocene time, voleanic rocks of . . ...................... 59-62

or later time, igneous rocks of........ 63-65 time, sedimentation in............... 82 See also Kenai formation.

Erosion in Miocene time.

in Pliocene time ........................ $83-84$

F.

Fish and fisheries of southwestern Mlaska. 18-19,21 Fletcher, C. A., acknowledgments to........ 12 Food supplies of Alaska Peninsula........ 18-19, 21 Fossils, occurrence of, in Chignik formation. $43,44,40$ occurrence of, in Lower Cretaceous rocks 39-40 in Middle Jurassic rocks..............

in Naknek formation............... $85-36$ in Upper Cretaceous rocks............ 45

in Upper Triassic rocks.............. 30-31 of Kenal formation.................. $53-58$

Foster, R. A., acknowledgments to......... 13

Furs of Alaska Peninsula ................. 21

G.

Geologic history of the region............... 76-81 Geomorphology of the region.............. 81-95

Glaciation, general effects of .............. 84-85 of Balboa-Herendeen Bay district....... 87-90 of Chignik Bay region.................. 90-91 of Popof Island. ...................... 87 of Unga Island . . . . . . . . . Gold, deposits and production of, on Alaska Peninsula................... 128 deposits and production of, on Popof Island....................... 125 on Unalaska Island.............. 127-128 on Unga Island................ 125-127 developments of, on Alaska Peninsula... 20-21 suggestions to prospectors for ............. 131

Granite, occurrence of ................... 31-32

Grewingk, $\mathrm{C}$, book on Alaska by .

$\pi$.

Harbors, location of, in southwestern Alaska. Herendeen Bay, Miocene sediments near....
Page.

Herendeen Bay coal field, developments at.. 19-20

Ferendeen Bay region, maps showing ...... 12,42 stratigraphy of......................... 29

Fierendeen limestone, occurrence of.......... 39

History, geologic, record of ............... $70-81$

Hollick, Arthur, on flora of Kenai formation. $\quad 5 i$

Hook Bay, coal bed at, description of...... 113-114 view of, plate showing................ 108

\section{I.}

Igneous rocks, summary of $71-73$

\section{K.}

Kenai formation, character of............... 49-52 fauna and flora of..................... 52-58 stratigraphy of ......................... $58-59$

Knopi, Adolph, acknowledgments to....... 12 on alteration of volcanic rocks........... 72-73 on basalt at Port Moller................ 128 on volcanic rocks of Chignik Bay and Balbos Bay regions............ $60-62$

Knowiton, F. F., acknowledgments to ..... 12 on flora of Chigaik formation......... 44, 45, 46 on flora of Kenai formation........ 52-54,56-57

L.

Landsberg, G. M., acknowledgments to..... 12

Lovel, recent changes in................... 94-95 Lower Cretaccous rocks, occurrence of....... 38-41 Lower Jurassic rocks, oceurrence of.......... 31-32 Lütke, Admiral F. P., exploration by....... 10

M.

Mallard Duck Bay, prospects for gold at..... 128 Martin, G. C., on petroleum fields of Alaska. 121-124 work of, on geology of Alaska Peninsula. 11 Mesozoic time, early, events of.............. 77-78 late, events of ...................... 78-79

Middle Jurassic rocks, occurrence of.... 25, 26, 32-33 Mineral resources, distribution of........... 95-96

Miocene rocks, occurrence of............... $66-69$

Miocene time, erosion in ................ 82-83 uplift in ............................ 83 See also Eocene time, late.

Mountains, Aleutian range of.............. 13 Aleutian range of, peaks in, plate showing. $\quad 12$ voleanic, on west shore of Pavlov Bay, plate showing.

west of Cape Douglas, view of, plate showing.

N.

Naknek formation, occurrence of $25,33-35$

0.

Oil fields. See Petroleum, occurrence of

Oligocene series, absence of..................

P.

Paige, Sidney, work of, on geology of A laska Peninsula ......................

Palache, Charles, on diorite porphyrite of Chichagof Peak.................. 65 on volcanic rocks of Eocene age......... 48-49 work, of, on geology of Alaska Peninsula. I1 
Page.

Petroleum, Cold Bay, character of.

developments of, on Alaska Peninsula..

occurrence of, at Cold Bay.............120-124

occurrence of, at other places........... 124

Philbrick, F. R., acknowledgments to....... 13

Pillar, shore line, view of, plates showing... 62,92

Pinnacle Mountain, cross section of, figure showing..

Pleistocene deposits, character and occurrence of............................ $73-75$

Pliocene rocks, possible occurrence of....... 71

Pliocene time, erosion in................ 83-84

Popof Island, gold deposits and production

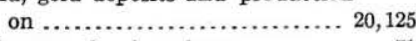

post-Miocene volcanic rocks on......... 71

Port Moller, Miocene sediments at........ 66-67 prospects for gold at.................. 128

Post, W.S., work of, on the geology of Alaska Peninsula....................

Prospect Bay, deposits of copper at........ 129 sketch map of..................... 129

Prospectors, suggestions to............. 130-131

Pumice, occurrence of ................... $\quad 75$

Pyramid Mountain, diagrammatic section of. view of, plate showing.

Q.

Quaternary deposits, occurrence of. ...... 73-76 Quaternary time, events of.

R.

Railroad, possible route for, from Coal Valley....................... 107-108 Recent deposits, character and occurrence of. 75-76 Russia, explorations in Alaska by. 9-11

L.

Sand dunes, occurrence of. ............... $\quad 76$

Settlements of the region................ 18-19 Shore lines, modern, character of. . . . . . . . 92-94 Shumagin mine, description of . ......... 21,127 Sitka mine, description of........... 21, 126-127 Smoking Mountain, location of............ 13 Spurr, J. E., on Naknek formation. . ........ 33-34 work of, on the geology of southwestern Alaska.

Stack, shore line, view of, plate showing Staniukovich shale, occurrence of.......... 38-39 Stanton, T. W., acknowledgments to....... 12 on fauna of Chignik formation......... 43, 45 on fauna of Naknek formation.......... 36 work of, on geology of Alaska Peninsula.
Stone, R. W., work of, on the geology of Page. Alaska Peninsula............. 11 Stratigraphy of the region........... 23-25, 29-30

Structure, general, of the region.......... 27-28 Syenite, occurrence of................. 31-32 T.

Terrace, sea, on Unga Island, view of, plate

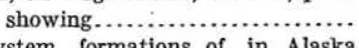
Tertiary system, formations of, in Alaska Peninsula................... 48-73 Tertiary time, events of.................. 79-81

Thompson Valley, coal beds in, description of......................... 112-113

exposure of coal in, view of, plate showing 108 Transportation in southwestern Alaska..... 22 Triassic. See Upper Triassic.

Tuliumit Point, view of, plate showing..... 38

U.

Unalaska Island, gold deposits and production on .................... 127-128

Unga formation, character of............. 66-68 fauna and flora of.................... 68 stratigraphy of. ...................... $68-69$

Unga Harbor, view of, plate showing....... 86

Unga Island, gold deposits and production on $20-21,125-127$

shore features on, sketch map of........ 93 shore line stack on, view of, plate showing.......................... 62 stratigraphy of.................... 29 structure sections on, figures showing . $66,68,70$ view of, plate showing............... 38 Unga Island coal field, developments at. ... $19^{\circ}$ Unga Island region, maps showing........ 12,42 Upper Cretaceous rocks, occurrence of. . . . . 4 41-48 Upper Jurassic rocks, occurrence of. ... 25, 26, 33-35 Upper Triassic rocks, occurrence of. ... 25, 26, 30-31

\section{V.}

Vegetation of the region................ 17-18

Volcanic rocks, description of............. 48-49 of late Eocene or early Miocene time.... 59-62 post-Miocene, character and occurrence of 69-71 See also Igneous rocks.

Volcanic tuff from Balboa Bay, view of, plate showing....................... 70 W.

Whalers Creek coal bed, description of..... 111-112 . 





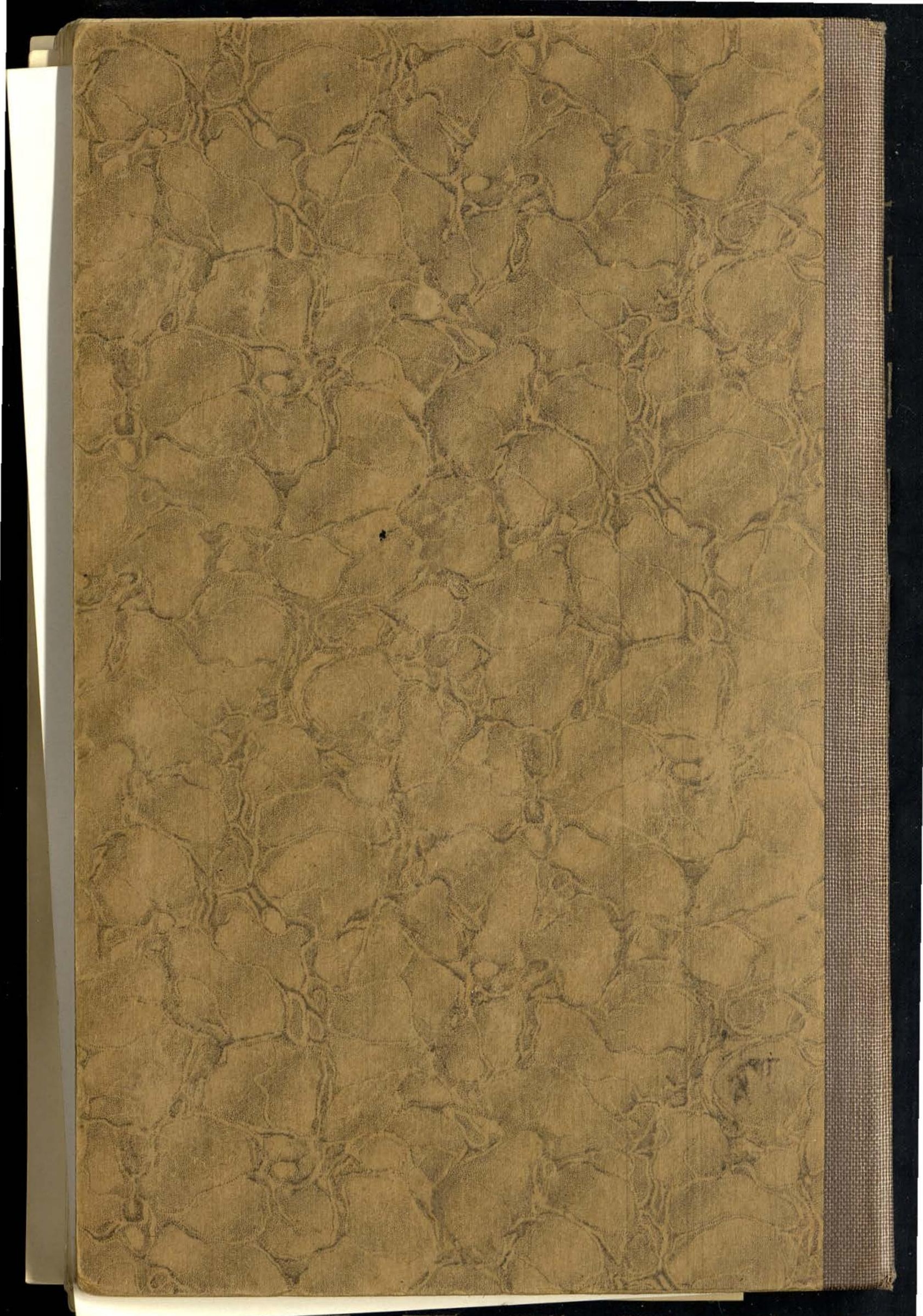

